REPORT NO.: MIT-GFR-045

NUCLEAR ENERGY RESEARCH INITIATIVE (NERI)

FINAL REPORT

Optimized, Competitive Supercritical- $\mathrm{CO}_{2}$ Cycle GFR for Gen IV Service

Final Report

April 2005-August 2008

September 8, 2008

Lead Organization: Massachusetts Institute of Technology

77 Massachusetts Avenue, Cambridge, MA 02139

Project (Grant No. DE-FC07-05ID14671)

Project No. 05-044

Lead Principal

Investigator

Professor M. J. Driscoll

MIT Dept. of Nuclear Science and Engineering

Bldg. 24-215A

77 Massachusetts Avenue

Cambridge, MA 02139

Tel: (617) 253-4219

Fax: (617) 258-8863

Email: mickeyd@mit.edu

\section{Contributing Investigators}

Dr. Pavel Hejzlar

Bldg. 24-215B

Tel: (617) 252-1570

Email: hejzlar@mit.edu

Prof. George Apostolakis

Bldg. 24-221

Tel: (617) 252-1570

Email: apostola@mit.edu

MIT Dept. of Nuclear Science and Engineering

77 Massachusetts Avenue

Cambridge, MA 02139

Fax: (617) 258-8863

DOE Project Manager

Kenny Osborne kenny.osborne@nuclear.energy.gov

Headquarters Technical Monitor

John Herczeg john.herczeg@nuclear.energy.gov

Headquarters Program Manager

Robert Versluis rob.versluis@nuclear.energy.gov 


\begin{abstract}
This is the final report under award DE--FC07-05ID14671, Project No. 05-44. An overall plant design was developed for a gas-cooled fast reactor employing a direct supercritical $\mathrm{CO}_{2}$ Brayton power conversion system. The most important findings were that (1) the concept could be capital-cost competitive, but startup fuel cycle costs are penalized by the low core power density, specified in large part to satisfy the goal of significant post-accident passive natural convection cooling; (2) active decay heat removal is preferable as the first line of defense, with passive performance in a backup role; (3) an innovative tube-in-duct fuel assembly, vented to the primary coolant, appears to be practicable; and (4) use of the $\mathrm{S}-\mathrm{CO}_{2}$ GFR to support hydrogen production is a synergistic application, since sufficient energy can be recuperated from the product $\mathrm{H}_{2}$ and $\mathrm{O}_{2}$ to allow the electrolysis cell to run $250^{\circ} \mathrm{C}$ hotter than the reactor coolant, and the water boilers can be used for reactor decay heat removal. Increasing core power density is identified as the top priority for future work on GFRs of this type.
\end{abstract}

\title{
Acknowledgement
}

"This material is based upon work supported by the Department of Energy under Award Number DE-FC07-05ID14671." The principal and collaborating investigators acknowledge the contributions of the following: M. A. Pope, C. S. Handwerk, M. J. Memmott, G. Patalano, S. A. McKee, D. Langewisch, Jeongik Lee, L. DeBesse, N. A. Carstens, and J. P. Gibbs..

\section{Disclaimer}

"This report was prepared as an account of work sponsored by an agency of the United States Government. Neither the United States Government nor any agency thereof, nor any of their employees, makes any warranty, express or implied, or assumes any legal liability or responsibility for the accuracy, completeness, or usefulness of any information, apparatus, product, or process disclosed, or represents that its use would not infringe privately owned rights. Reference herein to any specific commercial product, process, or service by trade name, trademark, manufacturer, or otherwise does not necessarily constitute or imply its endorsement, recommendation, or favoring by the United States Government or any agency thereof. The views and opinions of authors expressed herein do not necessarily state or reflect those of the United States Government or any agency thereof." 


\section{Table of Contents}

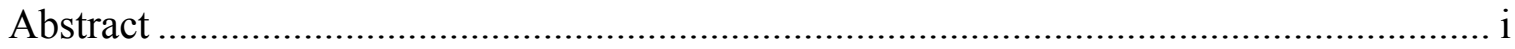

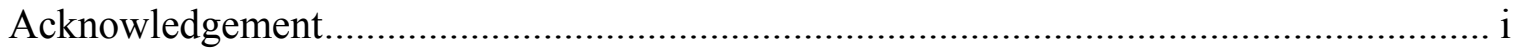

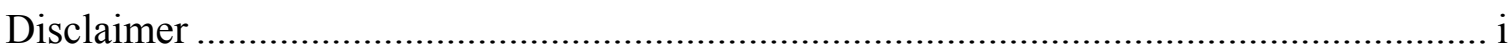

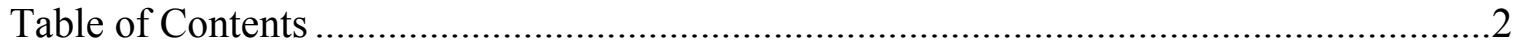

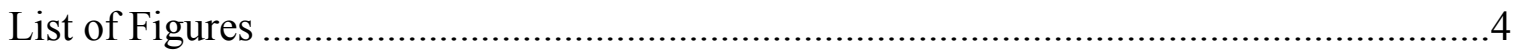

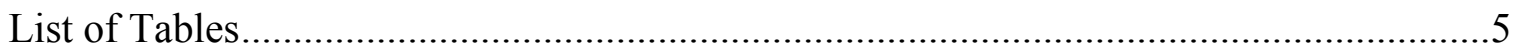

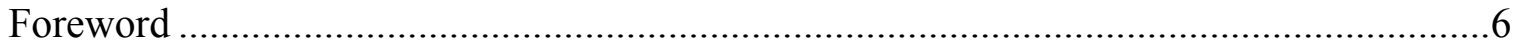

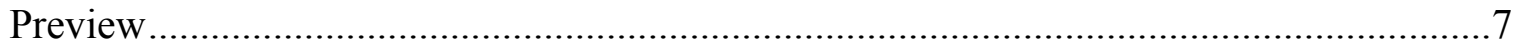

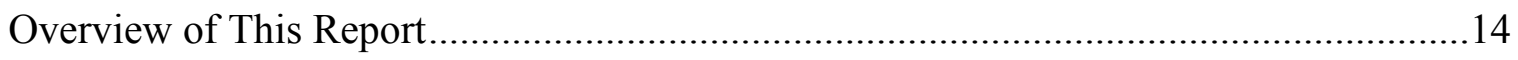

Organization of This Report......................................................................................14

Chapter 1 Task 1: Core Design and Performance Assessment .......................................15

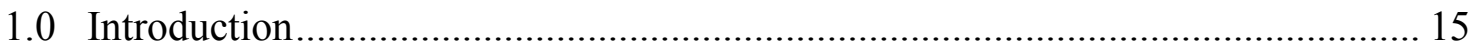

1.1 Evaluation of Vented Tube-in-Duct Fuel Assemblies .......................................... 15

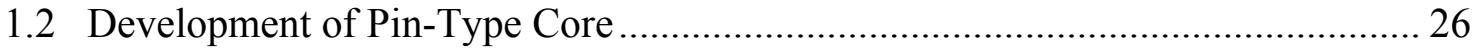

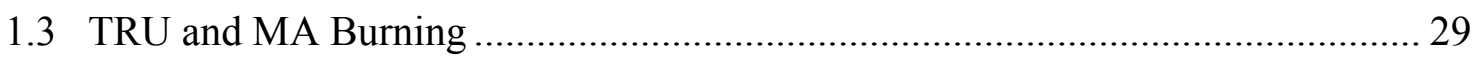

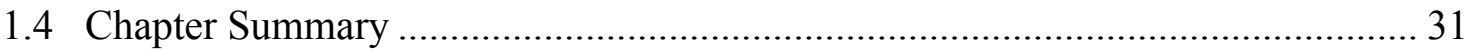

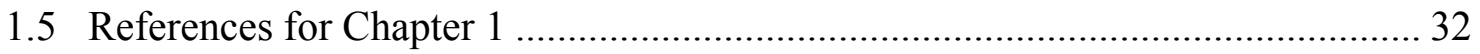

Chapter 2 Task 2: Design of Safety Assurance Systems ...............................................33

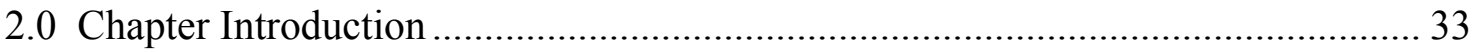

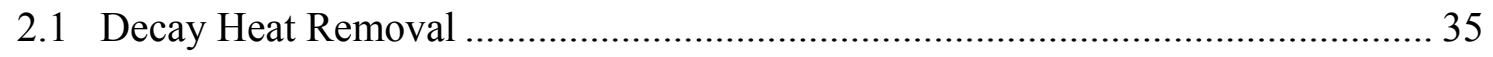

2.1.1 Some General Aspects of Core Cooling ....................................................... 35

2.1.2 Loss of Coolant Accidents ........................................................................ 38

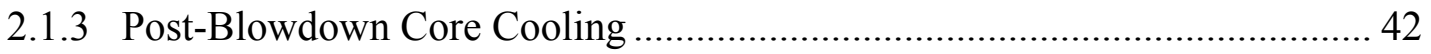

2.1.4 Evolution of Decay Heat Removal System (DHRS) Design......................... 44

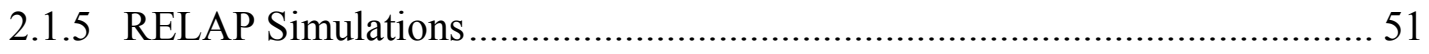

2.1.5.1 RELAP Simulations of Helium-Cooled GFR (INERI work) .................. 51

2.1.5.2 RELAP5 Simulations of S-CO $\mathrm{CO}_{2}$ Cooled GFR .......................................... 52

Loss of Coolant Accident with Scram …………………………………….... 56

Loss of Coolant Accident without Scram ......................................................... 58

2.1.6 Heat Transfer Deterioration in Low-Flow Post-LOCA Regimes ...................... 61

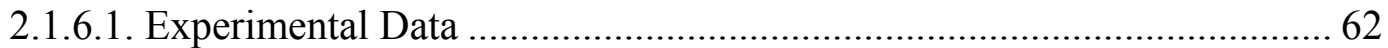

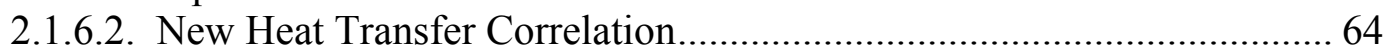

2.1.6.3. Additional Data in Natural Circulation Mode ......................................... 65

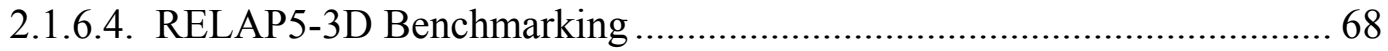

2.1.6.5. Numerical Predictions using LOCA-COLA ............................................ 75

2.1.6.6. Conclusions from Heat Transfer Experiments.......................................... 77 
2.2 Improved Emergency Power Provisions...................................................... 79

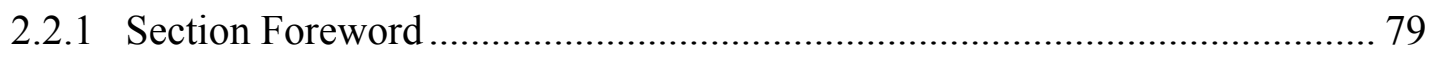

2.2.2 Emergency Power Supply Options ......................................................... 79

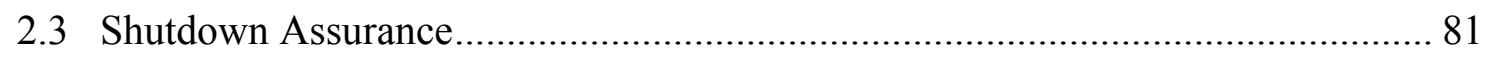

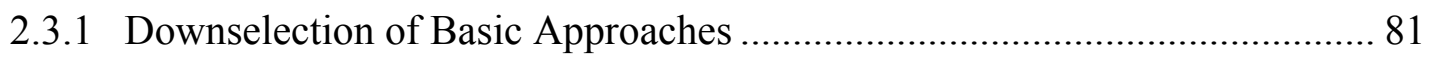

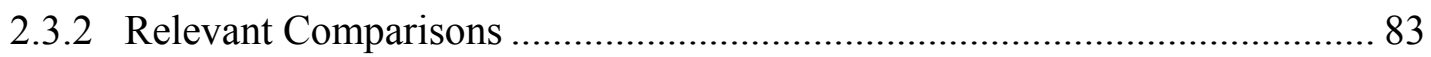

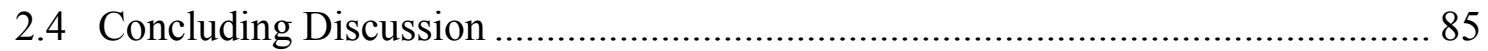

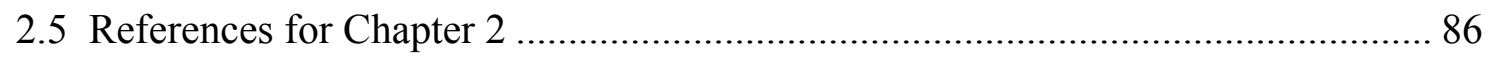

Chapter 3 Task 3: Overall Plant Design and Economic Assessment...............................88

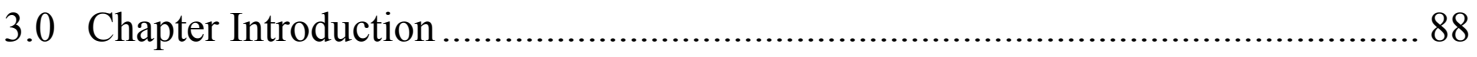

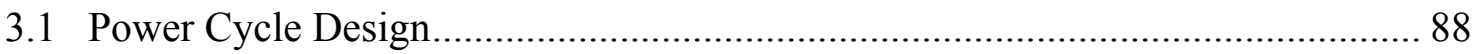

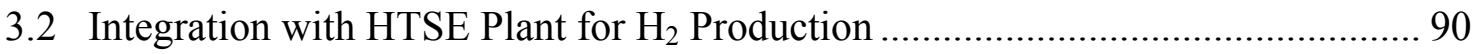

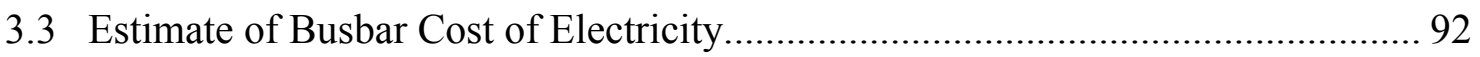

3.4 Chapter Summary, Discussion and Recommendations …………......................... 94

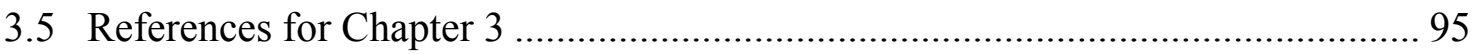

Chapter 4 Overall Conclusions and Potential Future Work ............................................96

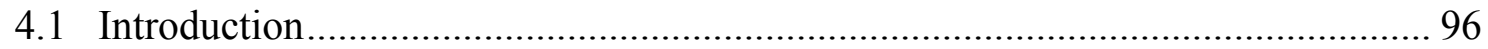

4.1.1 Comparison of CEA and MIT GFR Designs ………………..................... 98

4.1.2 Comparison of $\mathrm{S}_{-} \mathrm{CO}_{2}$ GFR with Sodium-Cooled Fast Reactor ..................... 99

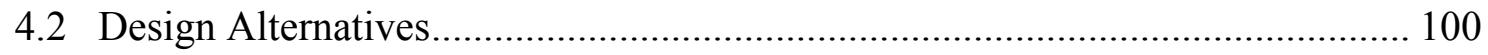

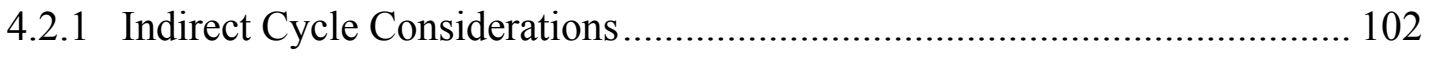

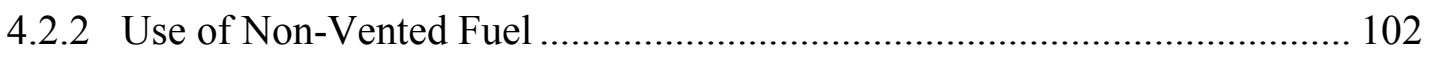

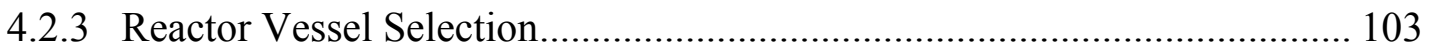

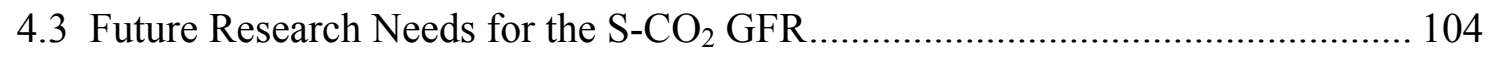

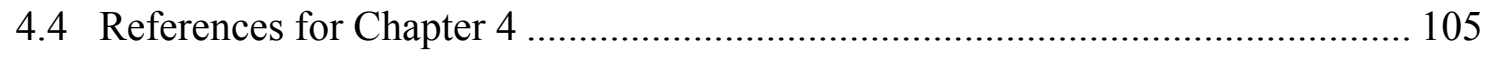

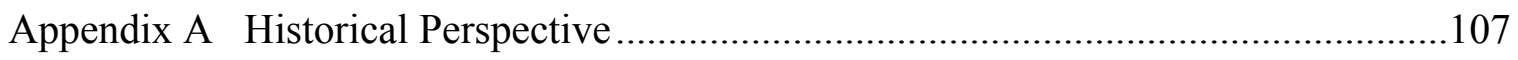

Appendix B GFR Project Publications as of 8/31/08 ................................................136

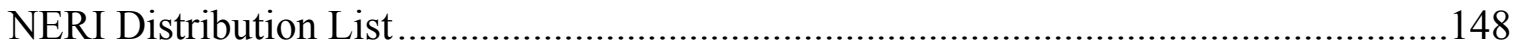




\section{List of Figures}

Figure 1.1: Final Vented Fuel Assembly Configuration.............................................. 16

Figure 1.2: Summary of Fission Product Transport Processes ..................................... 17

Figure 1.3: 1/6th Core Map of the Final Core Design Version ..................................... 18

Figure 1.4: Axial Cross Section of the S-CO $\mathrm{CO}_{2}$ GFR Core (not to scale)......................... 19

Figure 1.5: Acceptable T/H Envelope for TID Fuel with Homogeneous $\mathrm{BeO}$ (the scale on the right indicates fuel volume fraction) ....................................................... 23

Figure 1.6: Multiplication Factor as a Function of Burnup for Three Successive Cycles

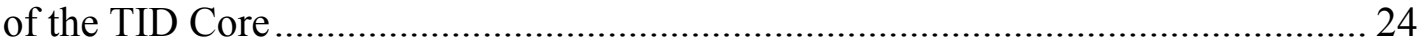

Figure 1.7: Unrodded Radial Power Shape as a Function of Burnup for the TID Core for

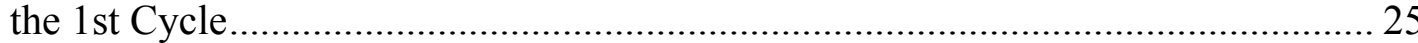

Figure 1.8: Pin-Type Core Layout and Key Parameters .............................................. 27

Figure 1.9: Comparison of Reactivity Limited Burnups Among TID and Pin Core

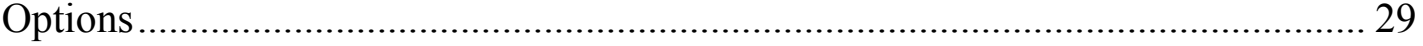

Figure 2.1: Map of Shutdown Cooling Operating Regimes 37

Figure 2.2: Cartoons showing consequences of isolation failure in a Single-loop LOCA

Figure 2.3: DHR Loop Natural Convection Flow Paths Seen in RELAP Simulations ... 43

Figure 2.4: Schematic of the CEA GFR DHR Loop Layout (1 of 3 x 100\%) ................ 45

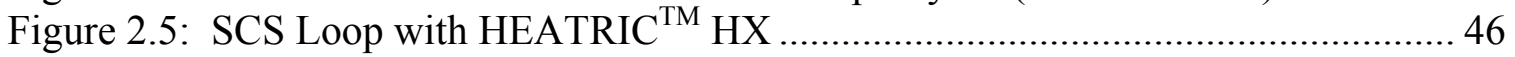

Figure 2.6: Layout of MIT GFR DHR Loops (1 of 4 x 50\%) ........................................ 47

Figure 2.7: Overall System Functional Failure as a Function of Single Loop Unreliability 50

Figure 2.8: Comparison of Failure Probability for Auxiliary Cooling Loop Options with

Common Cause Failures ................................................................................ 50

Figure 2.9: Post-LOCA Histories for Maximum Temperature in the Cladding .............52

Figure 2.10: GFR System (w/o DHR system) RELAP5-3D Nodalization...................... 54

Figure 2.11: GFR-SCS/ECS System RELAP5-3D Nodalization .................................. 55

Figure 2.12: $\mathrm{S}-\mathrm{CO}_{2}$ GFR pressure during $100 \mathrm{in}^{2}$ break LOCA with scram. ................... 57

Figure 2.13: $\mathrm{S}-\mathrm{CO}_{2}$ GFR mass flow rate of individual systems during $100 \mathrm{in}^{2}$ break

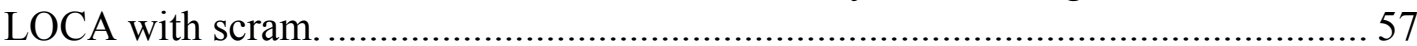

Figure 2.14: $\mathrm{S}-\mathrm{CO}_{2}$ GFR PCT during $100 \mathrm{in}^{2}$ break LOCA with scram........................ 58

Figure 2.15: $\mathrm{S}-\mathrm{CO}_{2}$ GFR reactor power during $100 \mathrm{in}^{2}$ break LOCA without SCRAM at

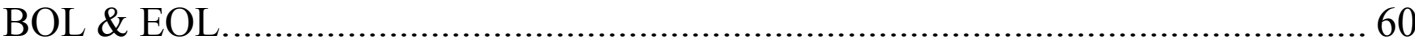

Figure 2.16: $\mathrm{S}-\mathrm{CO}_{2}$ GFR reactor peak cladding temperature during $100 \mathrm{in}^{2}$ break LOCA

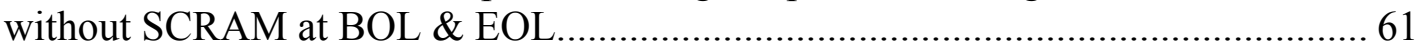

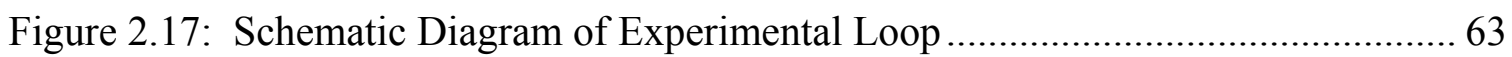

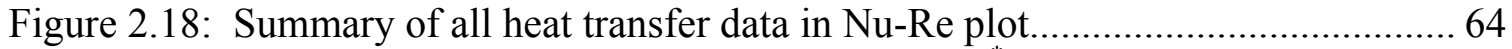

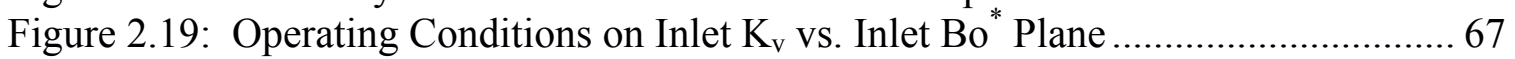

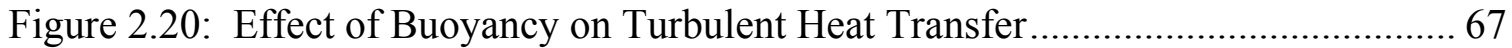

Figure 2.21: Effect of Acceleration on Turbulent Heat Transfer.................................... 68

Figure 2.22: Nodalization of the Experimental Facility for RELAP5-MOD3 Input....... 69

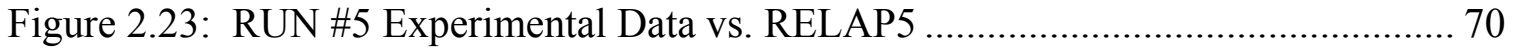

Figure 2.24: Inlet Bulk Temperature Difference vs. Mass Flow Rate Error .................. 72 


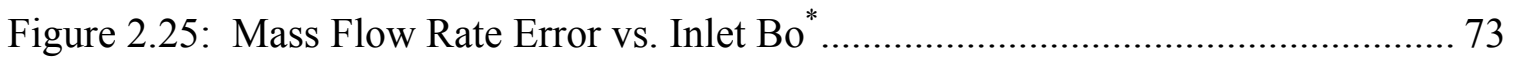

Figure 2.26: Mass Flow Rate Error vs. Inlet $K_{v}$ ……….......................................... 73

Figure 2.27: Friction Factor Measurement Ratio vs. Local Bo ${ }^{*}$...................................... 74

Figure 2.28: RUN \#5 Experimental Data vs. LOCA-COLA .......................................... 76

Figure 2.29: Flow Levitated GFR Reactivity Shutdown Device..................................... 82

Figure 2.30: Reactivity Effects and Their Compensation in MIT GFR ......................... 85

Figure 3.1 1200 MWe 2-Loop Plant Layout (Top View) ............................................. 89

Figure 3.2: $1200 \mathrm{MWe}$ Direct $\mathrm{SCO}_{2}$ Cycle (Side View) ............................................. 89

Figure 3.3: Cycle efficiency comparison of advanced power cycles............................. 90

Figure 3.4: HTSE Water Boiler Loop (one of four) which also serves for decay heat

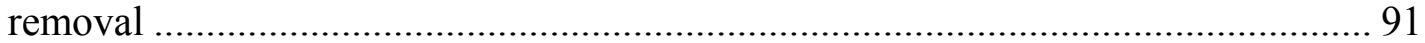

Figure 3.5: Arrangement of Reactor and Power Conversion Units ............................... 93

Fig. A.1 Family Tree of GFR Projects at MIT as of Sept. 2004 .............................. 108

\section{List of Tables}

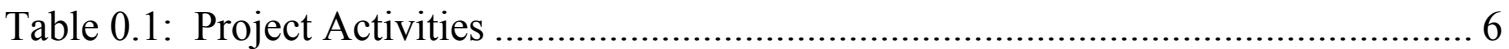

Table 0.2: Status of GFR Plant Features as of August 2008 .......................................... 7

Table 0.3: Reports by Task/Subtask ......................................................................... 8

Table 1.1: Neutronic and Thermal Hydraulic Goals for TID Core Design ..................... 20

Table 1.2: Key S- $\mathrm{CO}_{2}$-Cooled GFR Plant Parameters.................................................... 21

Table 1.3: Principal Parameters of the TID Fuel Assembly Core Design ........................ 22

Table 1.4: Neutronic Performance Parameter Comparisons for Three Successive Cycles

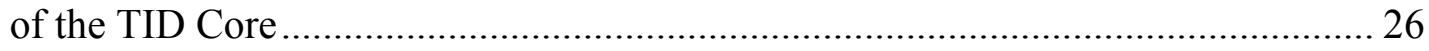

Table 1.5: Comparison of Thermal Hydraulic Parameters for TID and Pin Core Designs where Performance is Optimized....................................................................... 27

Table 1.6: Comparison of Key Neutronic Performance Criteria for the TID and Pin-Type

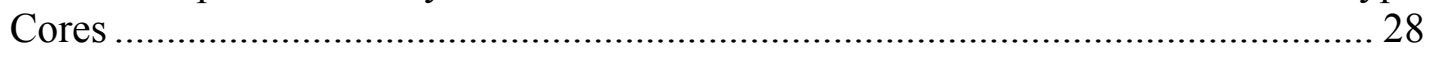

Table 1.7: Summary of Performance Comparison between Fertile and IMF Assemblies

Table 2.0: Safety Assurance for MIT S-CO $\mathrm{CO}_{2}$ GFR …………………………………... 34

Table 2.1: Thermal-Hydraulic Scaling Relations for GFR Core Cooling ........................ 36

Table 2.2: Failure of Protective Function for DHRS Layout.......................................... 49

Table 2.3: Experimental Conditions for Natural Circulation Loop .................................. 66

Table 2.4: Summary of RELAP5-3D Results............................................................ 70

Table 2.5: Summary of LOCA-COLA Results............................................................ 76

Table 2.6: Rating of Candidates for Emergency Power Supply ........................................ 80

Table 2.7: Rating of Candidates for Emergency Scram Supplementation ....................... 83

Table 4.1: Satisfaction of Gen-IV Attributes ............................................................... 96

Table 4.2: Status of GFR Plant Features as of August 2008 ........................................... 97

Table 4.3: Comparison of CEA and MIT GFR Designs................................................. 99

Table 4.4: Comparison of S-CO $\mathrm{CO}_{2}$ GFR with SFR ..................................................... 100

Table 4.5: Unorthodox features of S-CO $\mathrm{CO}_{2}$ GFR design, and fall-back alternatives....... 101 


\title{
NERI Final Project Report
}

\section{Optimized, Competitive Supercritical- $\mathrm{CO}_{2}$ Cycle GFR for Gen IV Service}

\author{
Project: No. 05-044 \\ April 2005 - September 2008
}

\section{Foreword}

This is the final report under the subject project, which had, as its overall goal, development of an integrated plant design for a gas-cooled fast reactor based on the compact, and highly efficient, direct supercritical carbon dioxide $\left(\mathrm{S}-\mathrm{CO}_{2}\right)$ Brayton power conversion system (PCS). This is in contrast with the mainstream GFR effort, which is focused on the use of helium, and a much higher temperature: on the order of $900^{\circ} \mathrm{C}$. In contrast, the $\mathrm{S}-\mathrm{CO}_{2} \mathrm{PCS}$ achieves comparable thermodynamic efficiency at $650^{\circ} \mathrm{C}$, which permits use of more-conventional materials

The results address the full spectrum of Gen IV goals, and should prove sufficient for evaluation of the design against other Gen IV concepts.

Table 0.1 organizes project activities into three tasks and nine subtasks, which will also serve as a convenient outline for summarizing project results.

\section{Task 1. Core Design and Performance Assessment}

1.1 Vented fuel concept using tube-in-duct assemblies: iterative optimization of features

1.2 Pin-type core design to serve as benchmark for comparisons and fallback option

1.3 Confirmation of TRU and minor actinide burning capability

\section{Task 2. PRA Guided Design of Safety Systems*}

2.1 Decay heat removal system design for accident, normal shutdown, and refueling service

2.2 Improved emergency site power systems: e.g. microturbines or fuel cells

2.3 Scram assurance via both active and passive means to marginalize ATWS

\section{Task 3. Overall Plant Design and Economic Assessment}

3.1 Design of power cycles for basic, advanced and developmental service, with core exit/turbine inlet temperatures of 550,650 and $700^{\circ} \mathrm{C}$, respectively; select between power conversion units inside PCIV versus in external loops

3.2 Demonstration of integration with a high temperature electrolysis of steam plant for $\mathrm{H}_{2}$ production

3.3 Estimation of busbar cost of electricity relative to other reactor options

\footnotetext{
* Note that this task coincides with work under INERI Project 2004-010-F: see 2007 Annual Report summary in Appendix A.
} 


\section{Preview}

Table 0.2 summarizes the major GFR design features as of project completion. The discussion in this report will elaborate on the more important aspects, emphasizing the end-results, with less mention of superseded earlier versions. In Table 0.3, which follows, major topical reports, papers and theses published in each subtask area are referenced, all of which can shed light on such details. Finally, Appendix B is a complete bibliography of all publications by MIT on this project, plus related contemporary and past closely related efforts.

Table 0.2: Status of GFR Plant Features as of August 2008

\begin{tabular}{|c|c|c|}
\hline Subsystem & Features & Comments \\
\hline \multicolumn{3}{|l|}{ Core } \\
\hline Fuel & $\mathrm{UO}_{2}+\mathrm{BeO}$ & LWR TRU fissile \pm MA \\
\hline Clad & ODS-MA956, or HT-9 & SiC a long range possibility \\
\hline Configuration & $\begin{array}{l}\text { tube-in-duct fuel assemblies, trefoil } \\
\text { or "hexnut" pellets, vented, orificed }\end{array}$ & $\begin{array}{l}\text { pin-type core as fallback is not } \\
\text { up to task }\end{array}$ \\
\hline Thermal-Hydraulics & $\begin{array}{l}\text { axial peaking factor } \leq 1.3 \\
\text { radial peaking factor } \leq 1.2 \\
\text { power density } \sim 85 \mathrm{~W} / \mathrm{cc}\end{array}$ & $\begin{array}{l}\text { Vary BeO fraction } \\
\text { to flatten power. } \\
\text { Lower than GA GCFR of } \\
1970 \text { 's @ } 235 \mathrm{~W} / \mathrm{cc} \\
\end{array}$ \\
\hline Burnup & $\geq 120 \mathrm{MWd} / \mathrm{kg}$ (avg) & $\begin{array}{l}\text { In single batch no-reshuffle } \\
\text { core, } 17 \text {-yr lifetime }\end{array}$ \\
\hline \multicolumn{3}{|l|}{ Safety Systems } \\
\hline Aux. Loops & $\begin{array}{l}\text { combined shutdown \& emergency, } \\
4 \times 50 \% \text { capable, active } \\
\text { forced convection; but passive } \\
\text { natural convection supplemented; } \\
\text { water boiler heat sink }\end{array}$ & $\begin{array}{l}\text { Based on RELAP parallel loop } \\
\text { calculations. For } \mathrm{P} \geq 0.7 \mathrm{MPa} \\
\text { natural convection alone may } \\
\text { suffice }\end{array}$ \\
\hline Emergency Power & Fuel cells to supplement diesels & $\begin{array}{l}\text { Projected to be more reliable } \\
\text { than diesels alone in long run }\end{array}$ \\
\hline \multicolumn{3}{|l|}{ Plant } \\
\hline $\begin{array}{l}\text { Power Conversion System } \\
\text { (PCS) }\end{array}$ & $\begin{array}{l}\text { supercritical } \mathrm{CO}_{2} \text { Brayton direct } \\
2 \times 600 \mathrm{MWe} \text { loops }=1200 \mathrm{MWe} \\
650^{\circ} \mathrm{C} \text { core exit/turbine inlet, } \\
\text { pressure: } 20 \mathrm{MPa}\end{array}$ & $\begin{array}{l}\text { AGRs in UK use } \mathrm{CO}_{2} \text { coolant } \\
\text { at } 4 \mathrm{MPa} \text { and } \\
\text { have } \mathrm{T} \sim 650^{\circ} \mathrm{C}\end{array}$ \\
\hline Reactor Vessel & $\begin{array}{l}\text { PCIV (prestressed cast iron reactor } \\
\text { vessel) }\end{array}$ & $\begin{array}{l}\text { Vessel houses loop isolation } \\
\text { and check valves plus shutdown } \\
\text { cooling heat exchangers }\end{array}$ \\
\hline Containment & $\begin{array}{l}\text { PWR type, steel liner reinforced } \\
\text { concrete } 0.7 \mathrm{MPa} \text { design capability } \\
70,000 \mathrm{~m}^{3} \text { free volume } \\
\text { filtered/vented }\end{array}$ & $\begin{array}{l}\text { Internally insulated and } \mathrm{CO}_{2} \\
\text { can be added to keep pressure } \\
\text { up to natural convection needs }\end{array}$ \\
\hline $\begin{array}{l}\mathrm{H}_{2} \text { production by steam } \\
\text { electrolysis } \\
\text { (optional) }\end{array}$ & $\begin{array}{l}\text { Separate water boiler loops }(4) @ \\
10 \% \text { of reactor power } \\
\text { Recuperation of } \mathrm{H}_{2} \& \mathrm{O}_{2} \text { heat allows } \\
\text { cell operation at } 850^{\circ} \mathrm{C}\end{array}$ & $\begin{array}{l}\text { Water boiler loops can also } \\
\text { serve for self-powered decay } \\
\text { heat removal }\end{array}$ \\
\hline
\end{tabular}


Table 0.3: Reports by Task/Subtask (see Bibliography, which follows)

\begin{tabular}{|llll|}
\hline Task 1 & \multicolumn{3}{l|}{ Core Design and Performance Assessment } \\
& 1.1 & Vented TID Fuel Core Design & Refs: 1.1-1 through 1.1-12 \\
& 1.2 & Pin Type Backup & Refs: 1.2-1 and 1.2-2 \\
& 1.3 & TRU \& MA Burning & Ref: 1.3-1 \\
\hline Task 2 & PRA-Guided Design of Safety Assurance Systems \\
& 2.1 & Decay Heat Removal Systems & Refs: 2.1-1 through 2.1-14 \\
& 2.2 & Improved Emergency Power & Refs: 2.2-1 through 2.2-3 \\
& 2.3 & Scram Assurance \& Licensing & Refs: 2.3-1 through 2.3-12 \\
& \multicolumn{3}{|l}{ Aspects } \\
& Overall Plant Design and Economic Assessment \\
& 3.1 & Power Cycle Design & Refs: 3.1-1 through 3.1-9 \\
& 3.2 & Use for High Temperature Steam & Refs: 3.2-1 and 3.2-2 \\
& Electrolysis & Busbar Cost of Electricity & Refs: 3.3-1 through 3.3-3 \\
\hline
\end{tabular}

\section{Bibliography Organized by Task/Subtask ${ }^{*}$}

\section{Task 1}

1.1-1 M.J. Driscoll, P. Hejzlar, N.E. Todreas, Fuel-In-Thimble GCFR Concepts for GEN-IV Service, ICAPP, Hollywood, FL, June 9-13, 2002.

1.1-2 M.A. Pope, M.J. Driscoll, P. Hejzlar, Reactor Physics Studies in Support of GFR Core Design, Trans. Am. Nucl. Soc., Proc. of GLOBAL '03, New Orleans, LA, Nov. 16-21, 2003

1.1-3 M.A. Pope, P.J. Yarsky, M.J. Driscoll, P. Hejzlar, P. Saha, An Advanced Vented Fuel Assembly Design for GFR Applications, Trans. Am. Nucl. Soc., Vol. 92, p.211, San Diego, CA, USA, June 5-9, 2005

1.1-4 C.S. Handwerk, M.J. Driscoll, P. Hejzlar, Use of Beryllium Oxide to Shape Power and Reduce Void Reactivity in Gas Cooled Fast Reactors, PHYSOR 2006

1.1-5 M.A. Pope, M.J. Driscoll, P. Hejzlar, Reactor Physics Design of Supercritical $\mathbf{C O}_{2}$-Cooled Fast Reactors, MIT-ANP-TR-104, September 2004

\footnotetext{
* Note: Some publications are relevant to more than one task or subtasks. Only most relevant publications listed; for a more complete list see Appendix B.
} 
1.1-6 M.A. Pope, P. Hejzlar, M.J. Driscoll, Thermal Hydraulics of a 2400 MWth

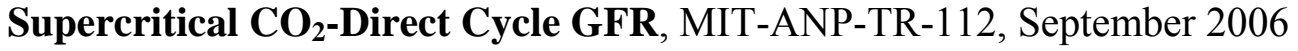

1.1-7 C.S. Handwerk, P. Hejzlar, M.J. Driscoll, Core Design and Performance Assessment for a Supercritical $\mathbf{C O}_{2}$-Cooled Fast Reactor, MIT-ANP-TR-113, May 2007

1.1-8 C.S. Handwerk, Optimized Core Design of a Supercritical Carbon Dioxide Cooled Fast Reactor, PhD Thesis, MIT Dept. of Nuclear Science and Engineering, May 2007

1.1-9 S. A. McKee, Assessment of Fuel Assembly Venting for Supercritical $\mathbf{C O}_{2}$ Cooled Fast Reactors, MIT-GFR-043, May 2008

1.1-10 S. A. McKee, Implementation of Vented Fuel Assemblies in the Supercritical $\mathbf{C O}_{2}$-Cooled Fast Reactor, SM Thesis, MIT Dept. of Nuclear Science and Engineering, May 2008

1.1-11 S. A. McKee, M. J. Driscoll, An Evaluation of Vented Gas Cooled Fast Reactor Fuel, Trans. Am. Nucl. Soc., Vol. 98, June 2008

1.1-12 C. S. Handwerk, M. J. Driscoll, P. Hejzlar, Optimized Core Design of a Supercritical Carbon Dioxide-Cooled Fast Reactor, Scheduled for Publication in Nuclear Technology, December 2008 issue

1.2-1 C.S. Handwerk, M.J. Driscoll, P. Hejzlar, Comparison of Tube-in-Duct and Pin Fuel for S- $\mathrm{CO}_{2}$ Cooled Fast Reactor Applications, Trans. Am. Nucl. Soc., Vol. 96, June 2007

1.2-2 C.S. Handwerk, P. Hejzlar, M.J. Driscoll, Core Design and Performance Assessment for a Supercritical $\mathbf{C O}_{2}$-Cooled Fast Reactor, MIT-ANP-TR-113, May 2007

1.3-1 C.S. Handwerk, P. Hejzlar, M.J. Driscoll, Core Design and Performance Assessment for a Supercritical $\mathbf{C O}_{2}$-Cooled Fast Reactor, MIT-ANP-TR-113, May 2007

Task 2 
2.1-1 Y. Okano, P. Hejzlar, N.E. Todreas, M.J. Driscoll, Thermal-Hydraulics and Post-Shutdown Cooling of a $\mathrm{CO}_{2}$-Cooled, Gas Turbine Fast Reactor, Trans. Am. Nucl. Soc., Vol. 86, p.139-141, Hollywood FL, June 9-13, 2002

2.1-2 M.J. Driscoll. P. Hejzlar, Active or Passive Post-LOCA Cooling of GFRs?, Trans. Am. Nucl. Soc., Vol. 88, p.673-677, San Diego CA, June 1-5, 2003

2.1-3 W.C. Williams, P. Hejzlar, P. Saha, Analysis of a Convection Loop for GFR Post-LOCA Decay Heat Removal, Proc. of ICONE 12, April 25-29, Arlington, VA, 2004

2.1-4 W.C. Williams, P. Hejzlar, M.J. Driscoll, Decay Heat Removal from a GFR Core by Natural Convection, Proc. of ICAPP '04, Pittsburgh, PA, Vol. 90, June 13-17, 2004

2.1-5 P. Hejzlar, W.C. Williams, M.J. Driscoll, Hot Channel Flow Starvation of Helium Cooled GFRs in Laminar Natural Convection, Trans. Am. Nucl. Soc., Washington, DC, Vol. 91, pp. 202-204, Nov. 14-18, 2004

2.1-6 J. I. Lee, P. Hejzlar, Experimental and Computational Analysis of Gas Natural Circulation Loop, Proc. Internat. Congress on Advances in Nucl. Power Plants, ICAPP '07, Paper 7381, Nice, France, May 13-18, 2007

2.1-7 F.J. Mackay, G.E. Apostolakis, P. Hejzlar, Calculating the Unreliability of a Passive System, Trans. Am. Nucl. Soc., Vol. 96, June 2007

2.1-8 F.J. Mackay, G.E. Apostolakis, P. Hejzlar, Incorporating Reliability Analysis into the Design of Passive Cooling Systems with an Application to a Gas-Cooled Reactor, Nuclear Engineering and Design, Vol. 238, pp.217-228, 2008

2.1-9 G. Patalano, G.E. Apostolakis, P. Hejzlar, Risk-Informed Design Changes in a Passive Decay Heat Removal System, Nuclear Technology, Vol. 163, pp. 191-208, 2008.

2.1-10 Y. Okano, P. Hejzlar, N.E. Todreas, M.J. Driscoll, Thermal Hydraulics and Shutdown Cooling of Supercritical $\mathbf{C O}_{2}$ GT-GCFRs, MIT-ANP-TR-088, August 2002

2.1-11 W.C. Williams, P. Hejzlar, M.J. Driscoll, W-J. Lee, P. Saha, Analysis of A Convection Loop for GFR Post - LOCA Decay Heat Removal from a Block-Type Core, MIT-ANP-TR-095, March 2003

2.1-12 M.J. Delaney, C. Matos, B.T. Parks, J.P. Koser, Interim Report on Task 1, GFR PRA-Guided Plant Design and Core Materials Compatibility Studies for $\mathbf{C O}_{2}$ Cooled Reactor, Annual Report on Project: Plant Design and Core Materials 
Compatibility Studies for Supercritical $\mathrm{CO}_{2}$ Cooled Reactors, MIT-GFR-008, March 2004

2.1-13 M. Delaney, G.E. Apostolakis, M.J. Driscoll, Risk-Informed Design Guidance for a Generation-IV Gas-Cooled Fast Reactor Emergency Core Cooling System, MIT-GFR-013, May 2004

2.1-14 Michael J. Delaney, Design Guidance of a Generation-IV Gas-Cooled Fast Reactor Emergency Core Cooling System, SM Thesis, MIT Nucl. Eng. Dept., April 2005

2.2-1 M.J. Driscoll, P. Hejzlar, M.J. Delaney, W. C. Williams, C. Matos, Compressed Gas Emergency Power Supply for GFR Service, Trans. Am. Nucl. Soc., Pittsburgh, PA, Vol. 90, June 13-17, 2004

2.2-2 D. Akkaynak, M.J. Driscoll, P. Hejzlar, G. E. Apostolakis, M. W. Golay, E. G. Cravalho, Use of Fuel Cells to Power a High-Reliability GFR ECCS, Trans. Am. Nucl. Soc., Vol. 93, p.292, Washington D.C., USA, November 13-17, 2005

2.2-3 Derya Akkaynak, Use of Fuel Cells for Improving On-Site Emergency Power Availability and Reliability at Nuclear Power Plants, SM Thesis, MIT Dept. of Aeronautics and Astronautics, June 2005

$* \quad * \quad *$

2.3-1 M.J. Driscoll, M.A. Pope, P. Hejzlar, Device for Passive Reactivity Insertion During GFR LOCA, Trans. Am. Nucl. Soc., 2003 Winter Meeting, Vol. 89, p.578-579, New Orleans, LA, Nov. 16-21, 2003

2.3-2 M.J. Driscoll, M.A. Pope, P. Hejzlar, Self-Actuated Reactivity Insertion Device for GFR Service, Trans. Am. Nucl. Soc., 2003 Winter Meeting, Vol. 89, p.573-575, New Orleans, LA, Nov. 16-21, 2003

2.3-3 N.A. Carstens, M.J. Driscoll, LOCA-Powered SCRAM Device for GFRs, Trans. Am. Nucl. Soc., 2003 Winter Meeting, Vol. 89, p.576-577, New Orleans, LA, Nov. 1621,2003

2.3-4 M.J. Delaney, G.E. Apostolakis, A Probabilistic Analysis of General Design Criterion 35 for a Gas-Cooled Fast Reactor, Proc. of ICAPP '04, Pittsburgh, PA, Vol. 90, June 13-17, 2004

2.3-5 L.P. Pagani, G.E. Apostolakis, P. Hejzlar, The Impact of Uncertainties on the Performance of Passive Systems, Nucl. Tech., Vol., 149, pp. 129-140, January 2005 
2.3-6 M.J. Delaney, G.E. Apostolakis, M.J. Driscoll, Risk-Informed Design Guidance for Future Reactor Systems, Nucl. Eng. and Design, Vol. 235, May 2005

2.3-7 M.A. Pope, M.J. Driscoll, P. Hejzlar, Shutdown / Emergency Cooling System For A 2400 MW $_{\text {TH }}$ Supercritical $\mathbf{C O}_{2}$-Cooled Direct-Cycle GFR, ICAPP '06, Paper 6097, Reno, NV, June 4-8, 2006

2.3-8 M.J. Driscoll and C.S. Handwerk, Tests of a Flow-Levitated Absorber for GFR LOF and LOCA Mitigation, Trans. ANS, Vol. 94, June 2006

2.3-9 Gregoire Jourdan, Using Risk-Based Regulations for Licensing Nuclear Power Plants: Case Study of the Gas-Cooled Fast Reactor, SM Thesis, MIT Nucl. Eng. Dept., February 2005

2.3-10 Craig Matos, Feasibility of Risk-Informed Regulation for Generation-IV Reactors, SM Thesis, MIT Nucl. Eng. Dept., June 2005

2.3-11 F.J. Mackay, Calculating Failure Probabilities of Passive Systems During Transients, SM Thesis, MIT Dept. of Nuclear Science and Engineering, Jan. 2007

2.3-12 G. Patalano, Risk-Informed Design Changes for a Passive Cooling System, SM Thesis, MIT Dept. of Nuclear Science and Engineering, Sept. 2007

Task 3

3.1-1 P. Hejzlar, V. Dostal, M.J. Driscoll, P. Dumaz, G. Poullennec, N. Alpy, Assessment of Gas Cooled Fast Reactor with Supercritical $\mathbf{C O}_{2}$ Cycle, ICAPP '05, Paper 5090, Seoul, Korea, May 15-19, 2005

3.1-2 V. Dostal, P. Hejzlar, M.J. Driscoll, High Performance Supercritical Carbon Dioxide Cycle for Next Generation Nuclear Reactors, Nuclear Technology, Vol. 154, No. 3, June 2006

3.1-3 J.P. Gibbs, P. Hejzlar, Y. Gong, M.J. Driscoll, Plant Layout for a 1200 MWe Direct Brayton Cycle GFR, Trans. Am. Nucl. Soc., Vol. 96, June 2007

3.1-4 V. Dostal, M.J. Driscoll, P. Hejzlar, N.E. Todreas, $\mathbf{C O}_{2}$ Brayton Cycle Design and Optimization MIT-ANP-TR-090, November 2002

3.1-5 V. Dostal, M.J. Driscoll, P. Hejzlar, A Supercritical Carbon Dioxide Cycle for Next Generation Reactors, MIT-ANP-TR-100, March 10, 2004

3.1-6 L. B. Fishkin, Prestressed Cast Iron Vessel (PCIV) Use for GEN-IV GFR Applications, MIT-GFR-006, April 2004 
3.1-7 Yunzhi Wang, Estimation of N-16 Dose Rate for Direct Cycle $\mathbf{C O}_{2}$ Gas Cooled Fast Reactors, MIT-GFR-032, August 2005

3.1-8 J.P. Gibbs, P. Hejzlar, M.J. Driscoll, Applicability of Supercritical $\mathbf{C O}_{2}$ Power

Conversion Systems to GEN IV Reactors, MIT-GFR-037, Sept. 15, 2006

3.1-9 M. A. Pope, Thermal Hydraulic Design of a 2400 MWth Direct Supercritical $\mathrm{CO}_{2}$-Cooled Fast Reactor, PhD Thesis, MIT Dept. of Nuclear Science and Engineering, Sept. 2006

3.2-1 M.J. Memmott, M.J. Driscoll, P. Hejzlar, Synergistic Configuration of a GFR for Hydrogen Production by Steam Electrolysis, Trans. ANS, Vol. 95, Nov. 2006

3.2-2 M.J. Memmott, M.J. Driscoll, M.S. Kazimi, P. Hejzlar, Hydrogen Production by Steam Electrolysis Using a Supercritical $\mathbf{C O}_{2}$-Cooled Fast Reactor, MIT-NES-TR007, Feb. 2007

3.2-3 M.J. Memmott, Hydrogen Production Using a Supercritical $\mathrm{CO}_{2}$-Cooled Fast Reactor and Steam Electrolysis, SM Thesis, MIT Dept. of Nuclear Science and Engineering, Feb. 2007

3.3-1 V. Dostal, P. Hejzlar, M.J. Driscoll, The Supercritical Carbon Dioxide Power Cycle: Comparison to Other Advanced Power Cycles, Nuclear Technology, Vol. 154, No. 3, June 2006

3.3-2 M.J. Driscoll, Interim Topical Report, Supercritical $\mathrm{CO}_{2}$ Plant Cost Assessment, MIT-GFR-019, Sept. 2004

3.3-3 M. J. Driscoll, Comparative Economic Prospects of the Supercritical $\mathrm{CO}_{2}$ Brayton Cycle GFR, MIT-ANP-TR-119, Feb. 2008 


\section{Overview of This Report}

This final project report is in the form of an expanded executive summary covering all of the three major tasks and nine subtasks defining the principal areas of investigation. Those interested in more detail are referred to the topical reports associated with each subtask, as identified elsewhere in this introductory chapter. A broader compilation of all reports issued by MIT relevant to the gas-cooled fast reactor in the modern era is contained in Appendix B. Even more detail, in historical sequence, is available in a sequential compilation of all quarterly reports issued over the course of the research:

Cumulative Compilation of Quarterly Reports, April 2005 - Sept. 2008, Project No. 05-044, "Optimized Competitive Supercritical $\mathrm{CO}_{2}$ Cycle GFR for Gen IV Service,” M. J. Driscoll (ed.), MIT-GFR-044, August 2008 (available in CD form only)

This report is written with $20 / 20$ hindsight, rather than in historical sequence, focusing on the final versions of all systems and analyses. The final chapter goes into considerable detail on recommended next steps should a decision be made to pursue the subject GFR concept in the future. Since the U.S. focus is currently on the use of sodium coolant, the report concludes with a brief generic comparison between the $\mathrm{S}-\mathrm{CO}_{2} \mathrm{GFR}$ and the SFR with respect to Gen-IV, AFCI and GNEP criteria.

Finally, note that a parallel NERI project compared liquid metal, liquid salt and $\mathrm{CO}_{2}$ cooled fast reactors. Results have been reported in:

N. E. Todreas, P. Hejzlar, "Flexible Conversion Ratio Fast Reactor Systems

Evaluation," Final Report, MIT-NFC-PR-101, June 2008

\section{Organization of This Report}

In consistency with the task coverage, the chapters of this report deal with (1) Core Design, (2) PRA-Guided Safety Assurance, and (3) Overall Plant Design and Economics.

A final chapter (No. 4) calls attention to possible areas deserving of follow-on work. 


\section{Chapter 1 Task 1: Core Design and Performance Assessment}

\subsection{Introduction}

The foreword to this final report listed the detailed topical reports applicable to each task and subtask, including specific references (which see). Attention was also called to an e-copy/CD-only compilation of all thirteen quarterly reports issued over the course of this project: MIT-GFR-044. This chapter summarizes the key findings under the three subtasks comprising Task 1 .

\subsection{Evaluation of Vented Tube-in-Duct Fuel Assemblies}

It was found early-on that use of an unconventional fuel assembly design was essential to project feasibility. The two principal drivers were the need to vent the fuel (as in the GA GCFR designs of the 1980s) to reduce the stress on the metal cladding; and the need to employ a high volume fraction fuel to achieve a "sustainable" unity conversion ratio in a blanket-free core. This latter condition is commonly imposed on recent fast reactor designs to avoid production of weapons grade plutonium.

To satisfy these constraints a tube-in-duct (TID) assembly configuration was devised. As shown in Figure 1.1, it consists of an array of "inverted" unit cells, with fuel outside of coolant tubes. The fuel can be either "hexnut" shaped beads which slide over the tubes, or trefoil slugs which slide down between them. The otherwise attractive option of vibratorily compacted powder had to be rejected because of its lower fuel density and thermal conductivity. The fuel is $\mathrm{UO}_{2}$ mixed with a variable amount of $\mathrm{BeO}$ (averaging about 30\%) to increase thermal conductivity and help flatten radial power in a way which has constant potency as a function of burnup as well as reduce coolant void reactivity. This makes possible a "battery" type core which does not require refueling or fuel shuffling over its more-than fifteen year lifetime. 


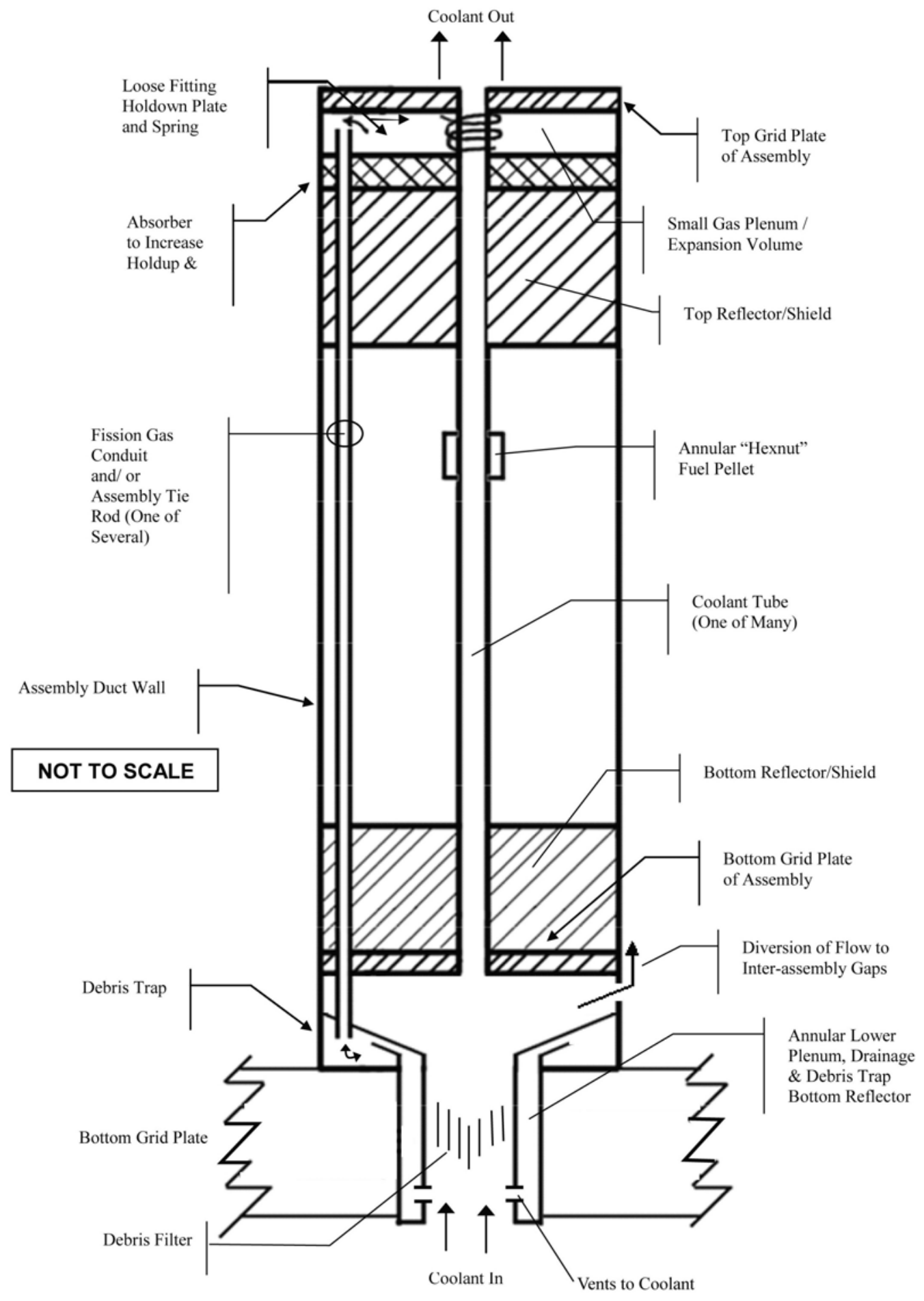

Figure 1.1: Final Vented Fuel Assembly Configuration

The design shown in Fig. 1.1 has the considerable additional advantage of easy incorporation of a long vent path - from the small top plenum between coolant tubes, down the entire length of the assembly into a larger lower plenum/debris trap at the 
colder coolant inlet. By itself a long vent path can reduce radionuclide content in the vented gas by many of orders of magnitude due to diffusive delay. There are then two major options: venting into the core grid plate and thence to a collection/purification system; or venting directly into the $\mathrm{CO}_{2}$ reactor coolant. The first is more analogous to the older GA approach, while the latter is, at this point, the reference design approach adopted here at project's end, pending in-pile loop studies to confirm computed performance parameters. One reason for this more optimistic course of action is that the change from $\mathrm{He}$ to $\mathrm{CO}_{2}$ is predicted to immobilize most otherwise-volatile fission product species in situ by formation of oxides or carbonates. Because of this the dominant vented species is $\mathrm{Kr}-85$, a noble gas with a 10.76 year half life.

Figure 1.2 traces the path of the fission products, from generation in fission to (potentially) escape into containment. As can be seen, reasonable primary coolant and containment volume purification rates can maintain tolerable levels of radionuclide concentrations. Plant surfaces are contaminated beyond "hands-on" maintenance limits, but this is to be expected for any direct-cycle reactor, even with non-vented fuel. Also note that during full power operation enough $\mathrm{N}-16\left(\mathrm{~T}_{1 / 2}=7.13 \mathrm{~s}\right)$ is created by fast neutron reaction with the $\mathrm{O}_{2}$ of $\mathrm{CO}_{2}$ (about as much as in the steam of a BWR) to require shielding and denial of up-close access.

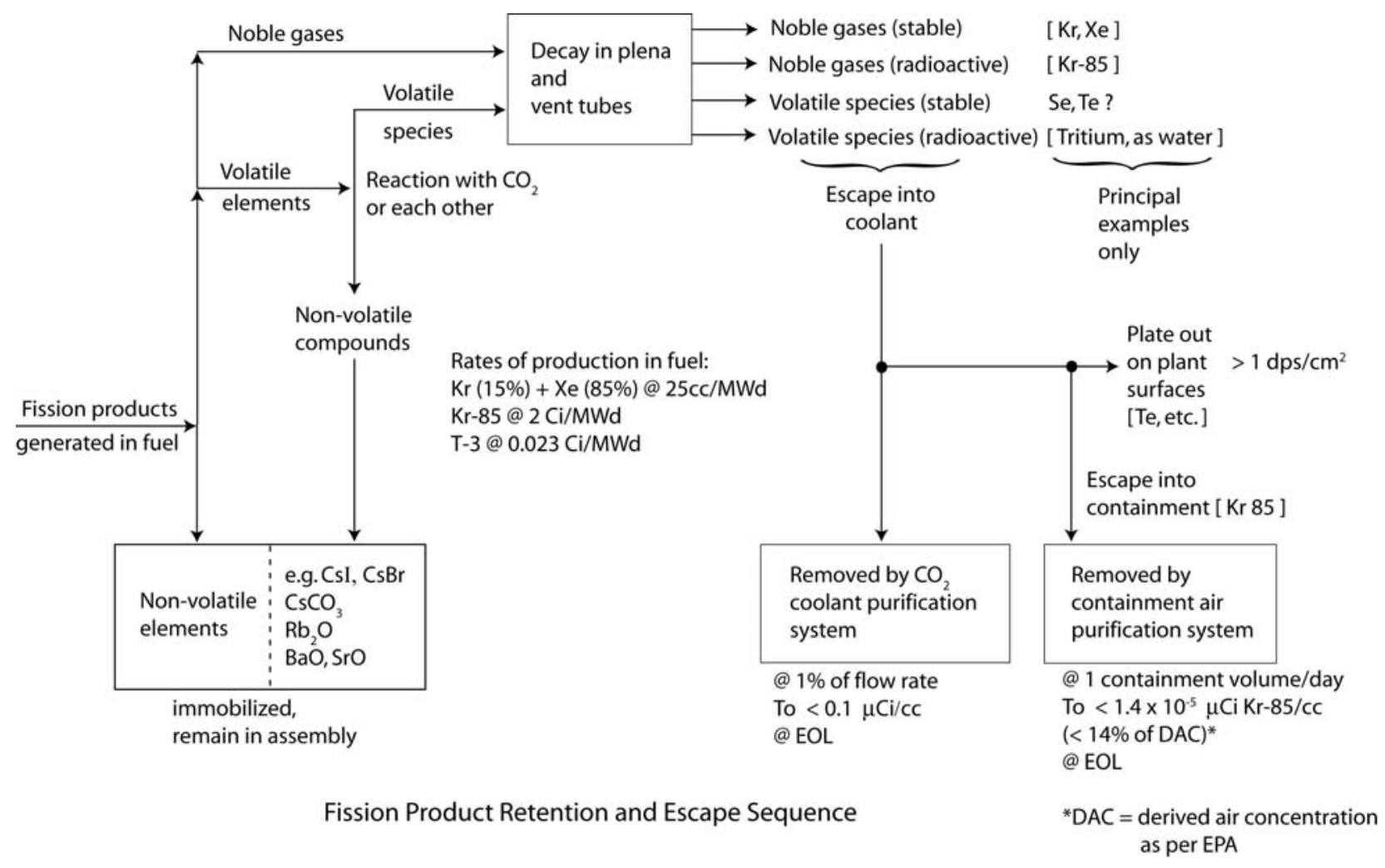

Figure 1.2: Summary of Fission Product Transport Processes

Turning next to core physics and thermal-hydraulic design, we again concentrate on features which distinguish the present concept from other gas (and otherwise) cooled 
fast reactors. What follows is a condensed version of the soon-to-be-published Ref 1-1, which is itself a synopsis of the topical reports listed elsewhere in this final report.

Table 1.1 lists the design goals for a core to operate under the direct cycle supercritical $\mathrm{CO}_{2}$ plant parameters specified in table 1.2. Table 1.3 documents the final version of the fuel assemblies and core devised to meet these goals and constraints. Figures 1.3 and 1.4 show the radial and axial layouts. Note in particular the use of radial high- $\mathrm{CO}_{2}$-content "reflector" assemblies as a way to insert significant negative reactivity during a LOCA.

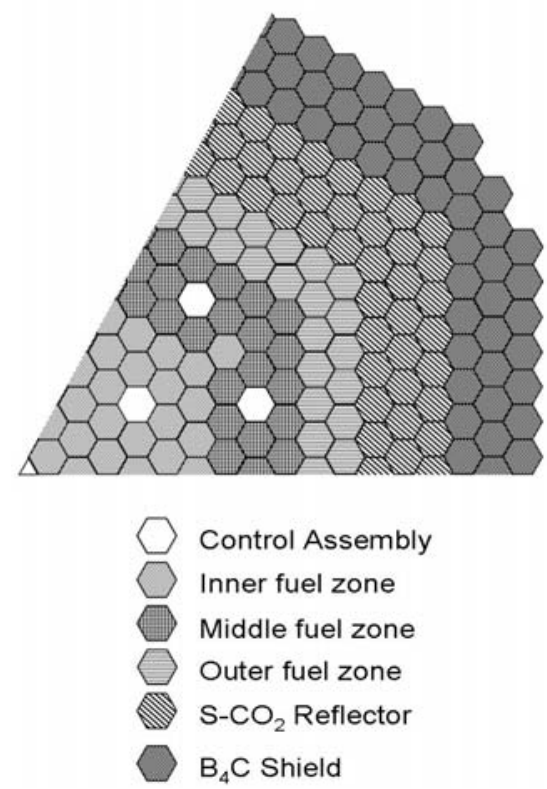

Figure 1.3: 1/6th Core Map of the Final Core Design Version 


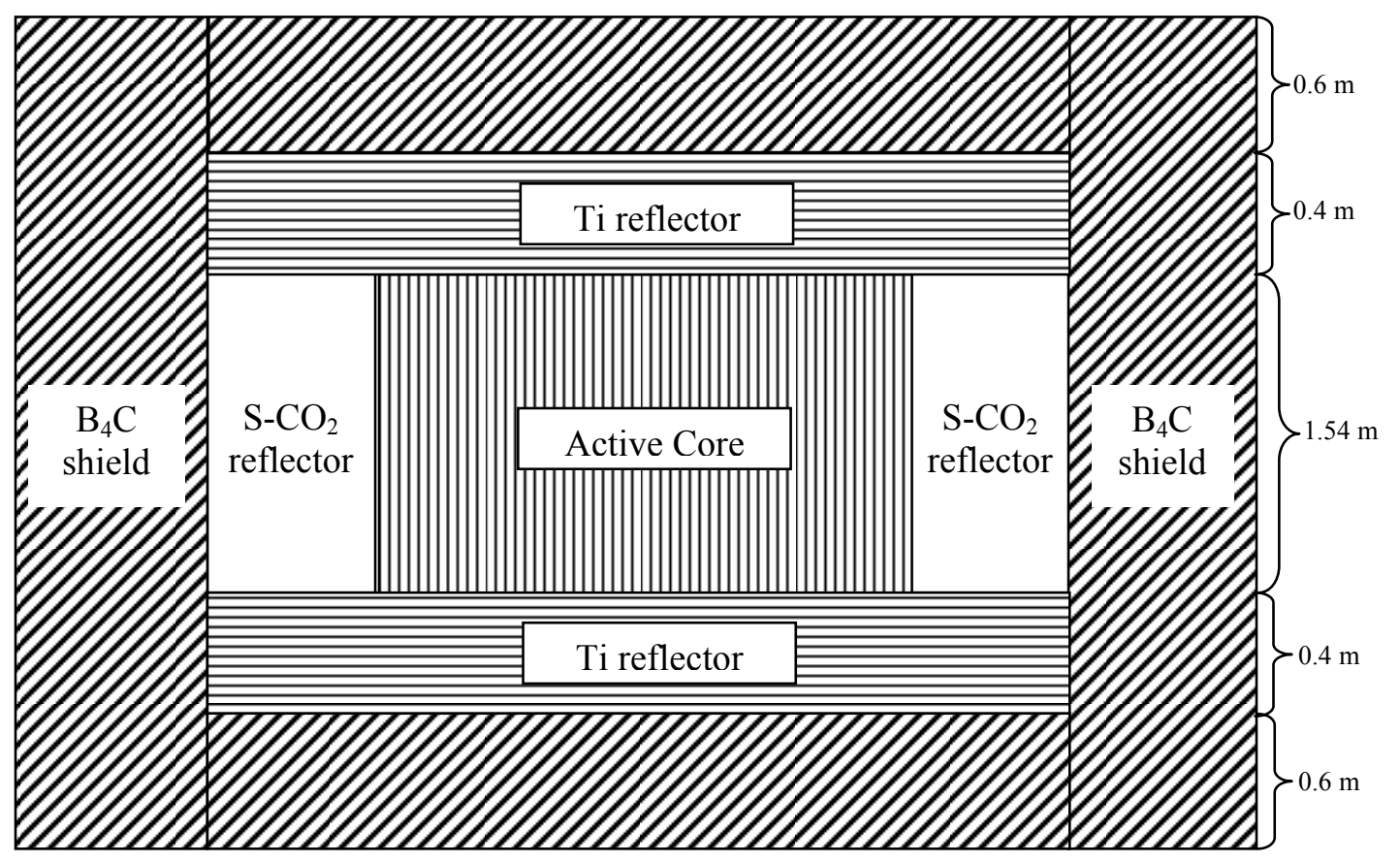

Figure 1.4: Axial Cross Section of the S-CO $\mathrm{C}_{2}$ GFR Core (not to scale) 


\section{Table 1.1: Neutronic and Thermal Hydraulic Goals for TID Core Design}

\begin{tabular}{|c|c|c|c|c|}
\hline Factor & Philosophy & $\begin{array}{l}\text { Acceptable } \\
\text { Value }\end{array}$ & $\begin{array}{l}\text { Target } \\
\text { Value }\end{array}$ & $\begin{array}{l}\text { Current Value } \\
\left(\mathrm{TID}, 1^{\text {st }} \text { cycle) }\right.\end{array}$ \\
\hline Achievable Burnup & $\begin{array}{l}\text { Achieve burnups such that the } \\
\text { GFR (1) is cost competitive } \\
\text { and (2) has fluence (both core } \\
\text { and reactor pressure vessel) } \\
\text { that is not excessive when } \\
\text { compared to other options }\end{array}$ & $\begin{array}{c}100 \\
\mathrm{MWD} / \mathrm{kg} \\
\text { (ave.) }\end{array}$ & $\begin{array}{c}150 \\
\mathrm{MWD} / \mathrm{kg} \\
\text { (ave.) }\end{array}$ & $\begin{array}{l}140 \mathrm{MWd} / \mathrm{kg} \\
\text { (ave.) }\end{array}$ \\
\hline Radial Power Peaking & $\begin{array}{l}\text { Keep the radial power shape } \\
\text { flat enough such that sufficient } \\
\text { margin to thermal hydraulic } \\
\text { limits is provided }\end{array}$ & 1.3 & 1.2 & $\begin{array}{l}1.34 @ 140 \\
\text { MWd/kg } \\
\text { (unrodded) }\end{array}$ \\
\hline $\begin{array}{l}\text { Passive Reactivity } \\
\text { Control }\end{array}$ & $\begin{array}{l}\text { Keep coolant void reactivity } \\
\text { low enough over core life such } \\
\text { that it can be sufficiently } \\
\text { offset by the accompanying } \\
\text { effect of other passive } \\
\text { reactivity mechanisms (i.e. } \\
\text { Doppler, flowering, etc). } \\
\text { Keep the method for doing } \\
\text { this simple. }\end{array}$ & $\leq \$ 1$ & $\leq \$ 0$ & $\begin{array}{c}-108 \pm 7 \notin(\mathrm{BOL}) \\
-119 \pm 7 \notin(\mathrm{MOL}) \\
-35 \pm 5 \phi(\mathrm{EOL})\end{array}$ \\
\hline $\begin{array}{l}\text { Peak Cladding } \\
\text { Temperature } \\
\text { (steady state) }\end{array}$ & $\begin{array}{l}\text { Keep the axial and radial } \\
\text { power shapes such that } \\
\text { sufficient margin to cladding } \\
\text { failure is provided }\end{array}$ & $800^{\circ} \mathrm{C}$ & $750^{\circ} \mathrm{C}$ & $810^{\circ} \mathrm{C}^{*}$ \\
\hline $\begin{array}{l}\text { Peak Fuel } \\
\text { Temperature } \\
\text { (steady state) }\end{array}$ & $\begin{array}{l}\text { Keep the axial and radial } \\
\text { power shapes such that } \\
\text { sufficient margin to fuel } \\
\text { melting is provided }\end{array}$ & $1800^{\circ} \mathrm{C}$ & $1700^{\circ} \mathrm{C}$ & $1770^{\circ} \mathrm{C}$ \\
\hline Core Pressure Drop & $\begin{array}{l}\text { Keep the core pressure drop } \\
\text { low enough such that (1) the } \\
\mathrm{S}-\mathrm{CO}_{2} \text { power conversion } \\
\text { system operates at a good } \\
\text { efficiency, and (2) natural and } \\
\text { forced circulation are not } \\
\text { significantly inhibited during } \\
\text { decay heat removal }\end{array}$ & $500 \mathrm{kPa}$ & $300 \mathrm{kPa}$ & $420 \mathrm{kPa}$ \\
\hline $\begin{array}{l}\text { Active Reactivity } \\
\text { Control (Reactivity } \\
\text { Swing/Control Rod } \\
\text { Worth) }\end{array}$ & $\begin{array}{l}\text { Keep the reactivity swing low } \\
\text { enough such that control rod } \\
\text { worth does not become } \\
\text { excessive (i.e. significantly } \\
\text { beyond current experience, } \\
\text { within rod ejection and stuck } \\
\text { rod limits) }\end{array}$ & $\begin{array}{l}\text { Within stuck } \\
\text { rod, ejected } \\
\text { rod, and } \\
\text { current } \\
\text { experience } \\
\text { envelope }\end{array}$ & $\begin{array}{l}\text { Within stuck } \\
\text { rod, ejected } \\
\text { rod, and } \\
\text { current } \\
\text { experience } \\
\text { envelope }\end{array}$ & $\begin{array}{l}\text { Within stuck rod, } \\
\text { ejected rod, and } \\
\text { current } \\
\text { experience } \\
\text { envelope }\end{array}$ \\
\hline
\end{tabular}

\footnotetext{
*before clad surface roughening
} 
Table 1.2: $\mathrm{Key} \mathrm{S-CO}$-Cooled GFR Plant Parameters

\begin{tabular}{|c|c|}
\hline Parameter & Value \\
\hline Core Thermal Output & $2400 \mathrm{MW}_{\text {th }}$ \\
\hline Power Conversion System (PCS) & Brayton Recompression Cycle \\
\hline Number of PCS loops & 2 \\
\hline Plant Electrical Output & $1130 \mathrm{MW}_{\mathrm{e}}$ \\
\hline PCS Thermal/Net Efficiency & $51 / 47$ \\
\hline Primary to Secondary Plant Coupling & Direct \\
\hline Primary Coolant/PCS Working Fluid & $\mathrm{S}-\mathrm{CO}_{2}$ \\
\hline Core Inlet Temperature & $485.5^{\circ} \mathrm{C}$ \\
\hline Core Outlet Temperature & $650^{\circ} \mathrm{C}$ \\
\hline Peak Coolant Pressure & $20 \mathrm{MPa}$ \\
\hline Plant Lifetime & 60 years \\
\hline Number of refueling cycles & 3 \\
\hline Number of refueling batches & 1 \\
\hline Decay Heat Removal (DHR) Capability & $4 \times 50 \%$ Shutdown Cooling Systems \\
\hline DHR System Working Fluid & $\begin{array}{c}\mathrm{CO}_{2} \text { (reactor side) } \\
\mathrm{H}_{2} \mathrm{O} \text { (ultimate heat sink side) }\end{array}$ \\
\hline
\end{tabular}


Table 1.3: Principal Parameters of the TID Fuel Assembly Core Design

\begin{tabular}{|c|c|}
\hline Parameter & Value \\
\hline \multicolumn{2}{|c|}{ Whole Core Parameters } \\
\hline Thermal Power & $2400 \mathrm{MW}_{\text {th }}$ \\
\hline Specific Power & $20.7 \mathrm{~kW} / \mathrm{kg}_{\mathrm{HM}}$ \\
\hline Power Density & $85.4 \mathrm{~kW} / 1$ \\
\hline Number of fuel batches & 1 \\
\hline Reactivity Limited Burnup & $\begin{array}{l}1^{\text {st }} \text { cycle: } 140 \mathrm{MWd} / \mathrm{kg}, 18.48 \mathrm{EFPY} \\
2^{\text {nd }} \text { cycle: } 133 \mathrm{MWd} / \mathrm{kg}, 17.66 \mathrm{EFPY} \\
3^{\text {rd }} \text { cycle: } 130 \mathrm{MWd} / \mathrm{kg}, 17.16 \mathrm{EFPY}\end{array}$ \\
\hline System Pressure & $20 \mathrm{MPa}$ \\
\hline Core Inlet Temperature & $485.5^{\circ} \mathrm{C}$ \\
\hline Core Outlet Temperature & $650^{\circ} \mathrm{C}$ \\
\hline Active Core Height & $1.54 \mathrm{~m}$ \\
\hline Effective Core Diameter & $4.81 \mathrm{~m}$ \\
\hline H/D (active core) & 0.32 \\
\hline Reflector & S-CO2 (radial), Ti (axial) \\
\hline Shielding (radial and axial) & $99 \mathrm{w} / \mathrm{o} \mathrm{B} \mathrm{B}_{4} \mathrm{C}$ \\
\hline \multicolumn{2}{|c|}{ Fuel Assembly Parameters } \\
\hline Fuel Assembly Description & Tube-in-Duct (TID) \\
\hline Number of fuel assemblies & 372 \\
\hline Number of control assemblies & 19 \\
\hline Fuel TRU concentration & $16.6 \%$ TRU $\left(1^{\text {st }}\right.$ cycle $)$ \\
\hline Assembly inner can flat-to-flat distance & $22.32 \mathrm{~cm}$ (cold), $22.49 \mathrm{~cm}$ (hot) \\
\hline Assembly outer can thickness & $0.2 \mathrm{~cm}$ (cold), $0.2015 \mathrm{~cm}$ (hot) \\
\hline Inter-Assembly gap size & $0.28 \mathrm{~cm}$ (cold), 0.111 (hot) \\
\hline Cladding thickness & $0.07 \mathrm{~cm}$ \\
\hline Coolant hole diameter & $0.7 \mathrm{~cm}$ \\
\hline Fuel, volume \% & $(\mathrm{U}-\mathrm{TRU}-\mathrm{Be}) \mathrm{O}_{2}, 59$ \\
\hline Cladding, volume \% & ODS MA956, 14 \\
\hline Coolant, volume \% & $\mathrm{S}-\mathrm{CO}_{2}, 27$ \\
\hline Peak fluence & $3.8 \times 10^{23} \mathrm{n} / \mathrm{cm}^{2}$ \\
\hline
\end{tabular}

The final design was iteratively adjusted to operate within the thermal hydraulic envelope of Fig. 1.5. Acceptable core candidates were then evaluated neutronically using a code which couples the MCNP Monte Carlo program and the ORIGEN burnup isotopics program. The resulting burnup reactivity history is shown in Fig. 1.6. Cores were batch-burned. The initial core was fueled with TRU recovered from PWR spent fuel, and the two successive recycles mixed recovered TRU with natural uranium. Table 1.4 shows several of the key core characteristics. Note in particular the negative coolant void reactivity for the unrodded state (rod insertion makes the values more negative). Figure 1.7 shows another important aspect of core behavior: the relatively flat and 
burnup-insensitive radial power profile, again unrodded (rod insertion pattern programming would further tune these results).

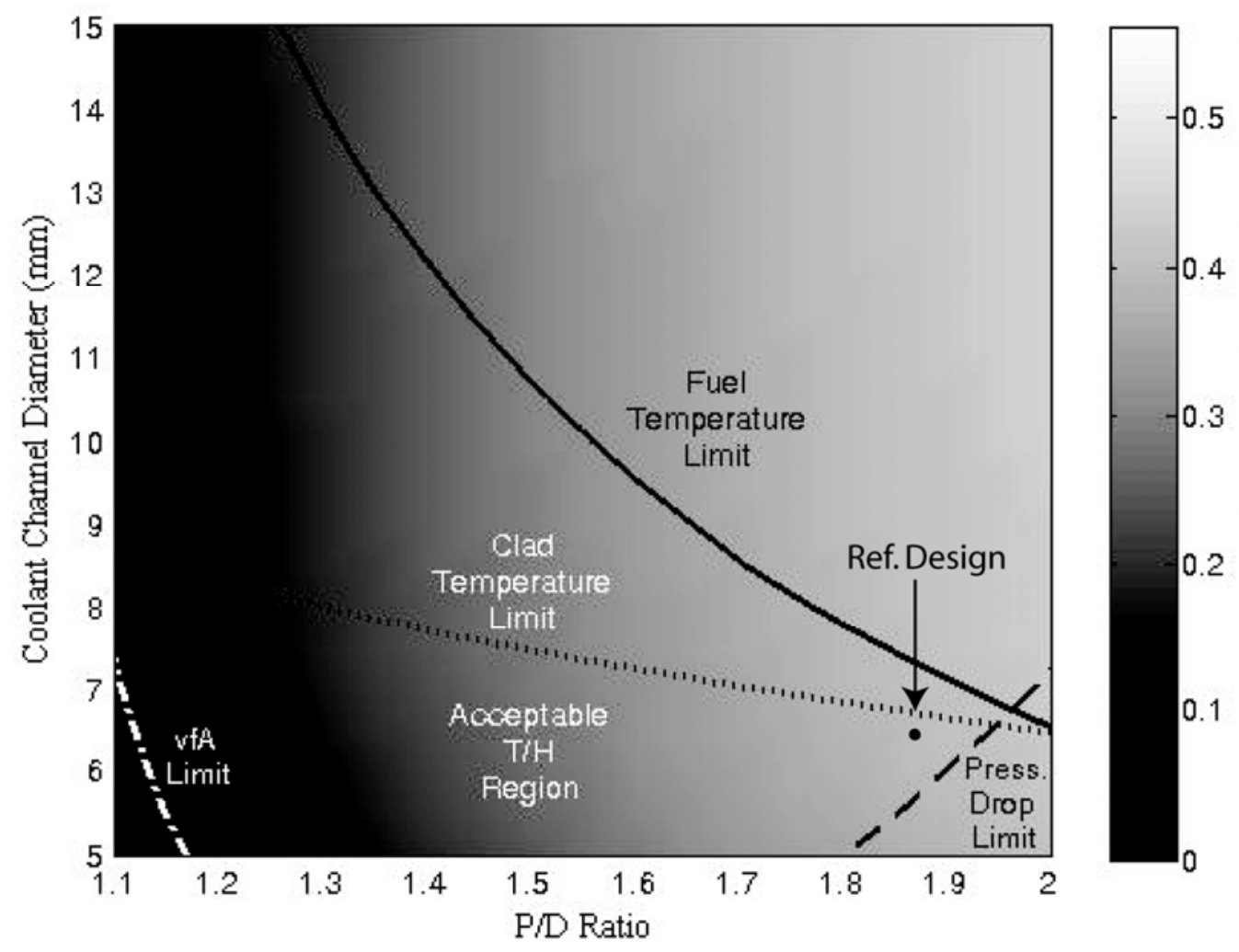

Figure 1.5: Acceptable T/H Envelope for TID Fuel with Homogeneous BeO (the scale on the right indicates fuel volume fraction) 


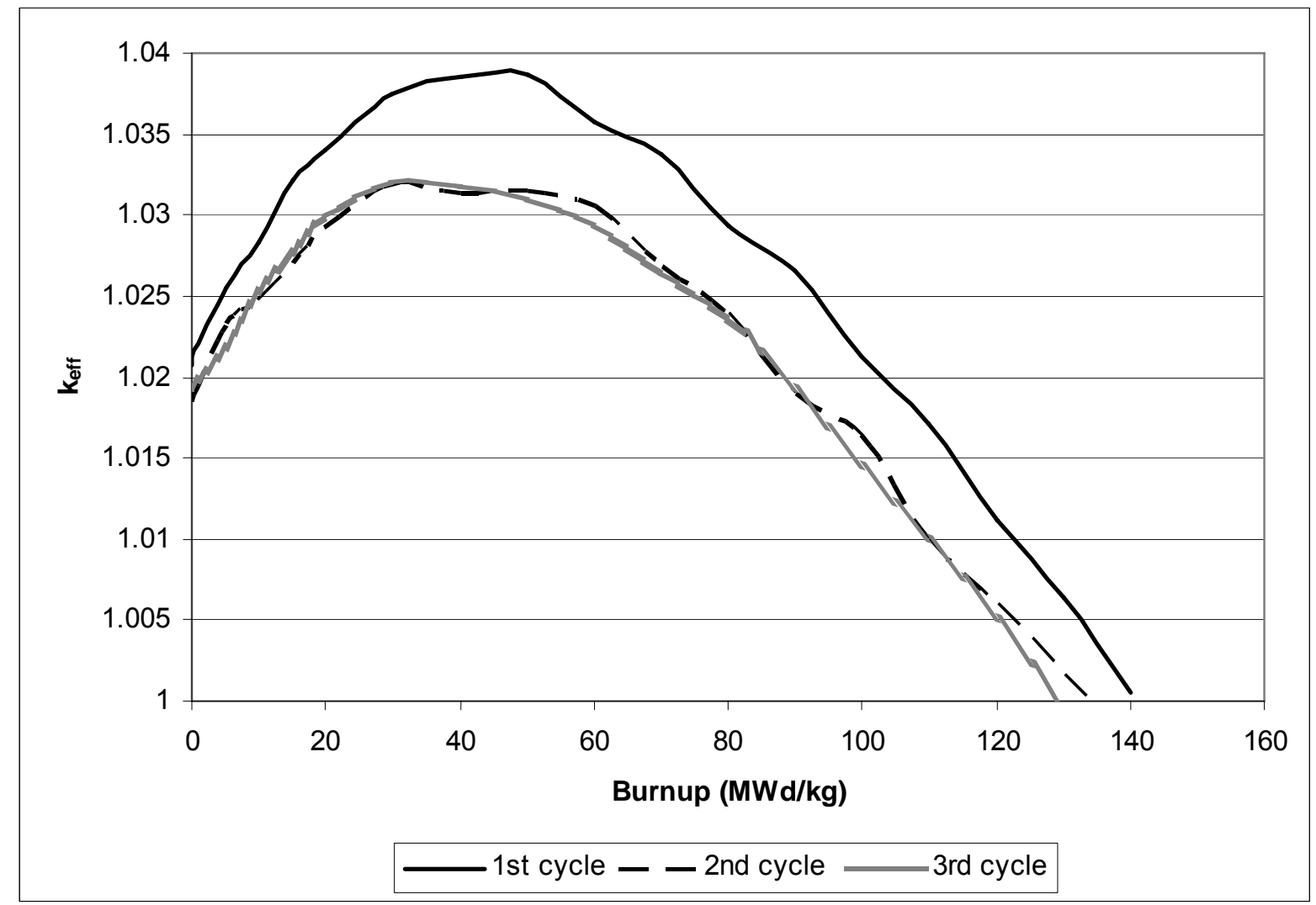

Figure 1.6: Multiplication Factor as a Function of Burnup for Three Successive Cycles of the TID Core 


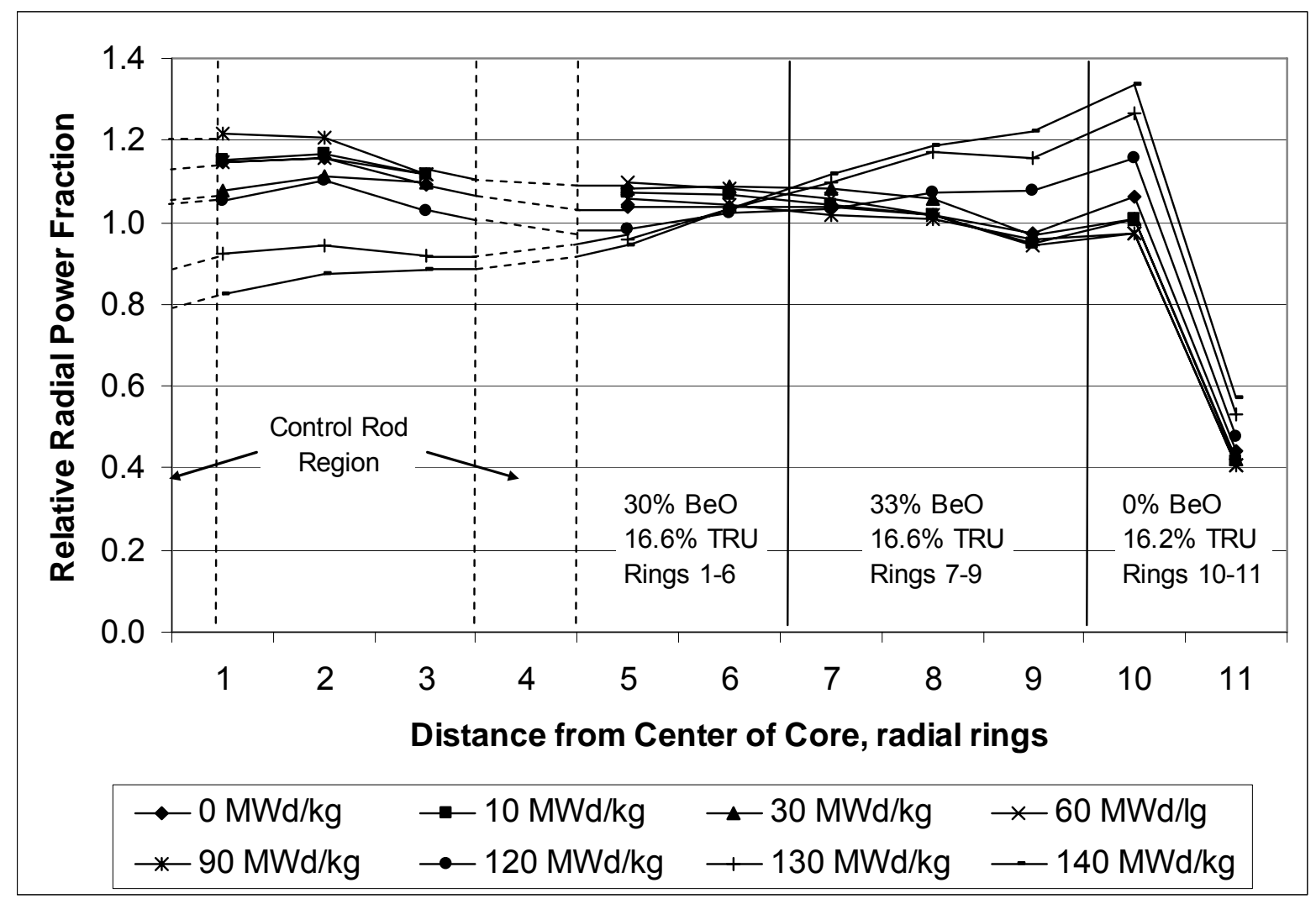

Figure 1.7: Unrodded Radial Power Shape as a Function of Burnup for the TID Core for the 1st Cycle 


\section{Table 1.4: Neutronic Performance Parameter Comparisons for Three Successive Cycles of the TID Core}

\begin{tabular}{|c|c|c|c|}
\cline { 2 - 4 } \multicolumn{1}{c|}{} & $1^{\text {st }}$ Cycle & $2^{\text {nd }}$ Cycle $^{*}$ & $3^{\text {rd }}$ Cycle $^{*}$ \\
\cline { 2 - 4 } & 140 & 133 & 130 \\
Reactivity Limited & 18.48 & 17.66 & 17.16 \\
\hline $\begin{array}{c}\text { Effective Full Power } \\
\text { Lifetime (EFPY) }\end{array}$ & 0.03726 & 0.03091 & 0.03106 \\
\hline $\begin{array}{c}\text { Reactivity Swing } \\
(\Delta \rho)\end{array}$ & 0.0045 & 0.0038 & 0.0040 \\
\hline $\begin{array}{c}\beta \text { eff unrodded at } \\
\text { time of peak excess } \\
\text { reactivity }\end{array}$ & $\$ 8.21$ & $\$ 8.19$ & $\$ 7.81$ \\
\hline Reactivity Swing & $1.34 @ \mathrm{EOL}$ & $1.28 @ 60 \mathrm{MWd} / \mathrm{kg}$ & $1.28 @ 60 \mathrm{MWd} / \mathrm{kg}$ \\
\hline $\begin{array}{c}\text { Unrodded } \\
\text { Maximum Radial } \\
\text { Peaking Factor }\end{array}$ & $-\$ 0.39+/-5 \phi$ & $-\$ 0.42+/-5 \phi$ & $-\$ 0.35+/-5 \phi$ \\
\hline $\begin{array}{c}\text { BOL CVR } \\
\text { (unrodded) }\end{array}$ & $-\$ 0.05+/-5 \phi$ & $-\$ 0.08+/-5 \phi$ & $-\$ 0.12+/-5 \phi$ \\
\hline $\begin{array}{c}\text { MOL CVR } \\
\text { (unrodded) }\end{array}$ & $-\$ 0.35+/-5 \phi$ & $-\$ 0.32+/-5 \phi$ & $-\$ 0.36+/-5 \phi$ \\
\hline $\begin{array}{c}\text { EOL CVR } \\
\text { (unrodded) }\end{array}$ &
\end{tabular}

*All TRU recovered from preceeding cycle is recycled in natural uranium; fission products are assumed to be removed with $100 \%$ efficiency; single batch "battery" fuel loading.

Other aspects of core performance are covered in subsequent subtask sections of this report. Of interest here are some follow-on suggestions should more work on the S$\mathrm{CO}_{2}$ GFR be contemplated at some point in the future.

The analyses carried out to devise the core design just described were based on deterministic mean value parameters and properties. Hot spot factors should be incorporated in any next-round iterations. The largest effects are anticipated to involve coolant heat transfer film $\Delta \mathrm{T}$. Conversely, roughening the upper half of the inside of the coolant flow tube channels should be evaluated. At the expense of increased pressure drop, this temperature difference could be significantly decreased, or added margin realized. We have previously mentioned control rod programming to further flatten radial power. This should be coupled with orificing of the outer ring of fueled assemblies: as shown in Fig. 1.7, they run at about half the core average assembly power.

More radical changes are discussed elsewhere in this report.

\subsection{Development of Pin-Type Core}


This task might at first appear trivial, since GA developed a GCFR based on pintype fuel in the 1970s. Fuel venting was also specified, and performance demonstrated using in-pile tests.

However, today's GFR (and all other FR concepts) is constrained to exclude uranium breeding blankets. This requires increasing fuel volume fraction (decreasing pin pitch) to achieve a core-only conversion ratio of unity. Core thermal-hydraulic constraints (pressure drop at full power and flow rate/clad temperature under natural convection) then become serious impediments to matching TID assembly performance. The optimized design parameters are summarized in Fig. 1.8 and a few key parameters compared to the reference TID assembly core are shown in Table 1.5. The peak cladding temperature is lower; but peak fuel temperature and pressure drop slightly higher: none of which are significantly beneficial or detrimental.

Table 1.5: Comparison of Thermal Hydraulic Parameters for TID and Pin Core Designs where Performance is Optimized

\begin{tabular}{|c|c|c|c|}
\hline Fuel Type & $\begin{array}{c}\text { Peak Cladding } \\
\text { Temperature }\end{array}$ & $\begin{array}{c}\text { Peak Fuel } \\
\text { Temperature }\end{array}$ & Pressure Drop \\
\hline Pin & $735.6^{\circ} \mathrm{C}$ & $1800^{\circ} \mathrm{C}$ & $435 \mathrm{kPa}$ \\
\hline TID & $810^{\circ} \mathrm{C}$ & $1770^{\circ} \mathrm{C}$ & $420 \mathrm{kPa}$ \\
\hline
\end{tabular}

\begin{tabular}{|c|c|c|}
\hline 1/6 ${ }^{\text {th }}$ Core Layout & Parameter & Value \\
\hline \multirow{12}{*}{$\begin{array}{l}\text { Control Assembly } \\
\text { Inner fuel zone } \\
\text { Middle fuel zone } \\
\text { Outer fuel zone } \\
\mathrm{S}_{-} \mathrm{CO}_{2} \text { Reflector } \\
\mathrm{B}_{4} \mathrm{C} \text { Shield }\end{array}$} & Fuel Rings & 13 \\
\hline & Active Core Height & $1.53 \mathrm{~m}$ \\
\hline & Core Volume & $31.12 \mathrm{~m}^{3}$ \\
\hline & H/D (active core) & 0.30 \\
\hline & $\begin{array}{l}\text { Assembly flat-to-flat } \\
\text { distance (outer can) }\end{array}$ & $20.2 \mathrm{~cm}$ \\
\hline & Clad Outer Diameter & $1.0 \mathrm{~cm}$ \\
\hline & $\mathrm{P} / \mathrm{D}$ & 1.1812 \\
\hline & $\begin{array}{l}\text { Fuel, volume \% } \\
\text { Assembly/core }\end{array}$ & $\begin{array}{l}\text { U/TRU, } \\
44.7 / 43.9\end{array}$ \\
\hline & $\begin{array}{c}\text { Cladding, volume } \% \\
\text { Assembly/core }\end{array}$ & $\begin{array}{c}\text { ODS MA 956, } \\
16.6 / 15.3\end{array}$ \\
\hline & $\begin{array}{l}\text { Coolant, volume } \% \\
\text { Assembly/core }\end{array}$ & $\begin{array}{c}\mathrm{S}-\mathrm{CO}_{2} \\
38.7 / 40.7\end{array}$ \\
\hline & Reflector & $\begin{array}{c}\mathrm{S}-\mathrm{CO}_{2} \text { (radial) } \\
\mathrm{Ti} \text { (axial) } \\
\end{array}$ \\
\hline & $\begin{array}{l}\text { Shielding } \\
\text { (radial and axial) }\end{array}$ & $99 \% / \mathrm{o} \mathrm{B}_{4} \mathrm{C}$ \\
\hline
\end{tabular}

Figure 1.8: Pin-Type Core Layout and Key Parameters 
The pin type core was shown to hold its unrodded radial power shape very well over its brief life, with the peak of 1.12, which is maintained throughout much of core life, varying only slightly. The maximum peak for the pin-type core is somewhat lower than that achievable for the TID core (1.34). This is due to two effects. First, the burnup of the pin core is significantly shorter than the TID core, which does not allow comparable spatially disparate fuel burnup throughout the core, as is the case with the TID core. Second, the lower fuel volume fraction of the pin-type core means that there is physically less fuel to burn in a spatially uneven manner; hence, it is easier to keep the radial power profile flatter over core life. Consequently, the pin core gains an edge over the TID core with respect to neutronic performance in this area; however, this advantage is small and is not likely to overcome the large shortcoming of its shorter lifetime.

Table 1.6: Comparison of Key Neutronic Performance Criteria for the TID and Pin-Type Cores

\begin{tabular}{|c|c|c|c|}
\hline & TID Core & Pin Core & $\begin{array}{l}1 \mathrm{~m} \text { taller } \\
\text { Pin Core }\end{array}$ \\
\hline $\begin{array}{l}\text { Reactivity Limited } \\
\text { Burnup (MWd/kg) }\end{array}$ & 140 & 61.6 & 80 \\
\hline $\begin{array}{l}\text { Reactivity Limited } \\
\text { Lifetime (EFPY) }\end{array}$ & 18.48 & 6.24 & 13.39 \\
\hline $\begin{array}{c}\text { Specific Power } \\
\left(\mathrm{kW} / \mathrm{kg}_{\mathrm{HM}}\right)\end{array}$ & 20.7 & 27.02 & 16.35 \\
\hline $\begin{array}{c}\text { Heavy Metal } \\
\text { Loading }\left(\mathrm{kg}_{\mathrm{HM}}\right)\end{array}$ & 115942 & 88823 & 146767 \\
\hline $\begin{array}{l}\text { Reactivity Swing } \\
(\mathrm{pcm})\end{array}$ & 3726 & 2017 & 2312 \\
\hline $\begin{array}{c}\text { Diluent }(\mathrm{BeO}) \\
\text { Zoning }(\% \mathrm{BeO})\end{array}$ & $30 / 33 / 00$ & $38 / 40 / 00$ & $38 / 40 / 00$ \\
\hline $\begin{array}{c}\text { Core Average } \mathrm{BeO} \\
(\text { volume } \%)\end{array}$ & 21 & 26.1 & 26.1 \\
\hline $\begin{array}{c}\text { Enrichment Zoning } \\
(\% \text { TRU })\end{array}$ & $16.6 / 16.6 / 16.4$ & $19.85 / 19.85 / 19.85$ & $18.69 / 18.69 / 19.1$ \\
\hline $\begin{array}{c}\text { Core Average } \\
\text { Enrichment } \\
(\% \text { TRU })\end{array}$ & 16.53 & 19.85 & 18.83 \\
\hline $\begin{array}{l}\text { Coolant Volume } \\
\text { Fraction (unit cell) }\end{array}$ & 25 & 35 & 35 \\
\hline $\begin{array}{c}\text { Maximum Rodded } \\
\text { CVR }(\varnothing)\end{array}$ & $\begin{array}{l}-36 \pm 5 \\
(\mathrm{EOL})\end{array}$ & $\begin{array}{l}-37 \pm 5 \\
(\mathrm{EOL})\end{array}$ & $\begin{array}{c}-2 \pm 4 \\
(\mathrm{EOL})\end{array}$ \\
\hline
\end{tabular}

Significant shortcomings were observed with pin-type fuel in its much shorter burnup capability, inability to achieve a $\mathrm{CR} \sim 1$, and higher critical enrichment: see Fig. 1.9 and Table 1.6, which also show the results of increasing pin core height to alleviate some of its shortcomings. This is due primarily to the much lower fuel volume fraction $\left(\mathrm{v}_{\mathrm{f}}\right)$ and consequently poor neutron economy. Conversely, the lower $\mathrm{v}_{\mathrm{f}}$ gave very favorable results with respect to $\mathrm{CVR}$, as axial leakage was enhanced. In an effort to 
improve the short lifetime of the pin-type core, an extra meter of core height was added in order to increase the heavy metal loading and improve the neutron economy by reducing axial leakage. While this was effective in increasing the reactivity limited lifetime and reducing the critical enrichment, it increased the contribution of CVR upon voiding. This demonstrated the fundamental design trade-off between neutron economy and CVR reduction through leakage.

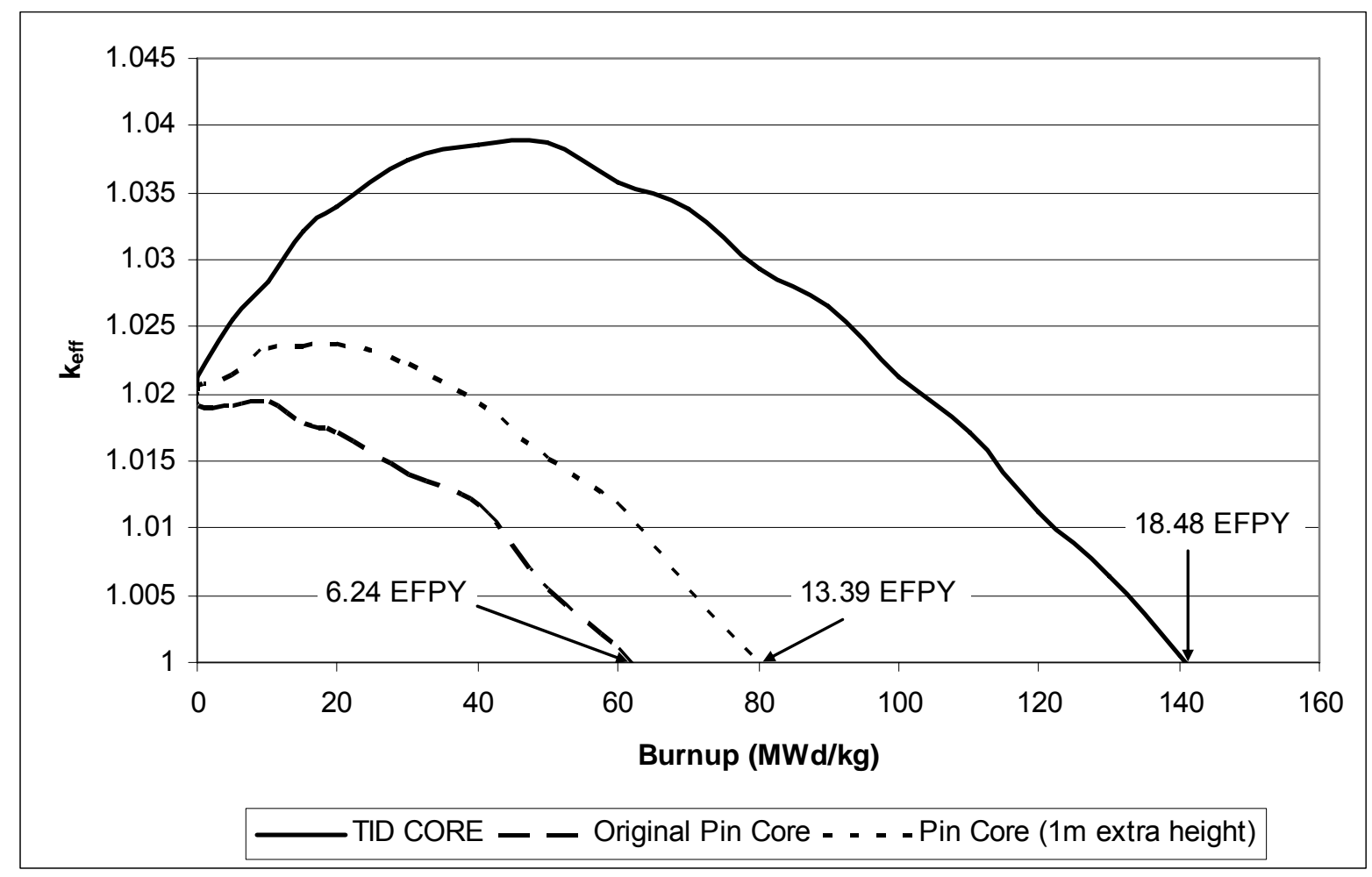

Figure 1.9: Comparison of Reactivity Limited Burnups Among TID and Pin Core
Options

The bottom line is that there is not a sufficiently broad design option space to permit one to devise a truly competitive pin-type core. The controlling variable is coolant volume fraction, which at approximately $40 \%$ is significantly lower than the GA GCFR value of $55 \%$. Even at $40 \%$ it is not possible to attain a unity conversion ratio, hence sustainability. Thus, unless breeding blankets are re-instated as a tolerable option, the pin-type core approach should be dropped.

\subsection{TRU and MA Burning}

This topic encompasses an extremely wide variation of options. For example, MA burning can be done in cores having conversion ratios ranging from zero to unity. Thus fuel non-TRU material can be either fertile (U-238) or inert matrix (e.g. MgO). A key point to be made is that the GFR, because of its negligible coolant moderation, can be modified to have a range of neutron energy spectra (hence spectrum-averaged cross 
sections) which span those of other fast reactor candidates. Spectrum softening by $\mathrm{BeO}$ (or $\mathrm{MgO}$ ) addition is the principal independent variable. The main shortcoming of the GFR, therefore, is not in the resulting isotope vectors, but in the rate of burning and transmutation due to its lower specific power versus SFR cores. It is, however, more competitive in this regard with fast reactors cooled by lead, helium or liquid salt.

In the present work the ability to manage several key long lived fission products (Tc-99 and I-129) and TRU for the TID GFR core was assessed and evaluated against current LWR practice and a competing Gen-IV design, the lead-cooled fast reactor, LFR. The TID GFR core was found to have an advantage in all of these areas with respect to the LWR case, due to the (1) substantially harder neutron spectrum, which leads to a greater in-situ burning capability and (2) the ability to recycle the fuel. While the numbers presented in this work show that the LFR is comparable in Tc-99 and I-129 production/destruction and superior in the ability to incinerate TRU, the difference in inter-cycle actinide management between the TID GFR core and the LFR account for the difference in TRU management performance. The TID GFR still has a net MA destruction rate, and given the similarity of the GFR and LFR spectra, the GFR has the potential to achieve near LFR-like TRU performance, should the same inter-cycle actinide management strategy be used.

As well, the proliferation resistance in terms of Pu isotopics of the TID GFR core was compared against that of current LWR practice and the LFR, with the GFR having a great advantage over the LWR and a slight advantage over the LFR in this area. While these auspicious results bode well from a proliferation standpoint, they are not favorable from an ease of reprocessing and fabrication standpoint.

Finally, the use of the GFR as a dedicated actinide burner, instead of the base-case breeder-burner role, was explored. A literature review and comprehensive analysis was conducted to determine that $\mathrm{MgO}$ was likely the best inert matrix fuel (IMF) to be used in an actinide burner concept for this GFR. This selection was based on the high melting point, good thermal conductivity, and superior irradiation performance in a fast neutron environment of $\mathrm{MgO}$, coupled with its predicted chemical compatibility with the $\mathrm{S}-\mathrm{CO}_{2}$ coolant. A quantitative comparison of two GFR IMF semi-infinite assemblies (with and without BeO diluent) was made with a TID GFR core assembly ("Fertile" case), with all evaluated using established neutronic criteria in seven different areas. The performance of the IMF (in both cases) was inferior to that of the Fertile case. While some performance shortcomings were corrected through the removal of the diluent in the fuel, the larger reactivity swing and much shorter reactivity limited lifetime proved the idea of using this GFR as a dedicated actinide burner with fertile-free fuel is not feasible. Moreover, fuel cycle simulations have shown that $\mathrm{CR}=0$ strategies are not needed to manage TRU. Table 1.7 summarizes the principal cases evaluated.

It is concluded that the $\mathrm{S}-\mathrm{CO}_{2}$ GFR could be a backup alternative to the SFR for GNEP service. 
Table 1.7: Summary of Performance Comparison between Fertile and IMF Assemblies

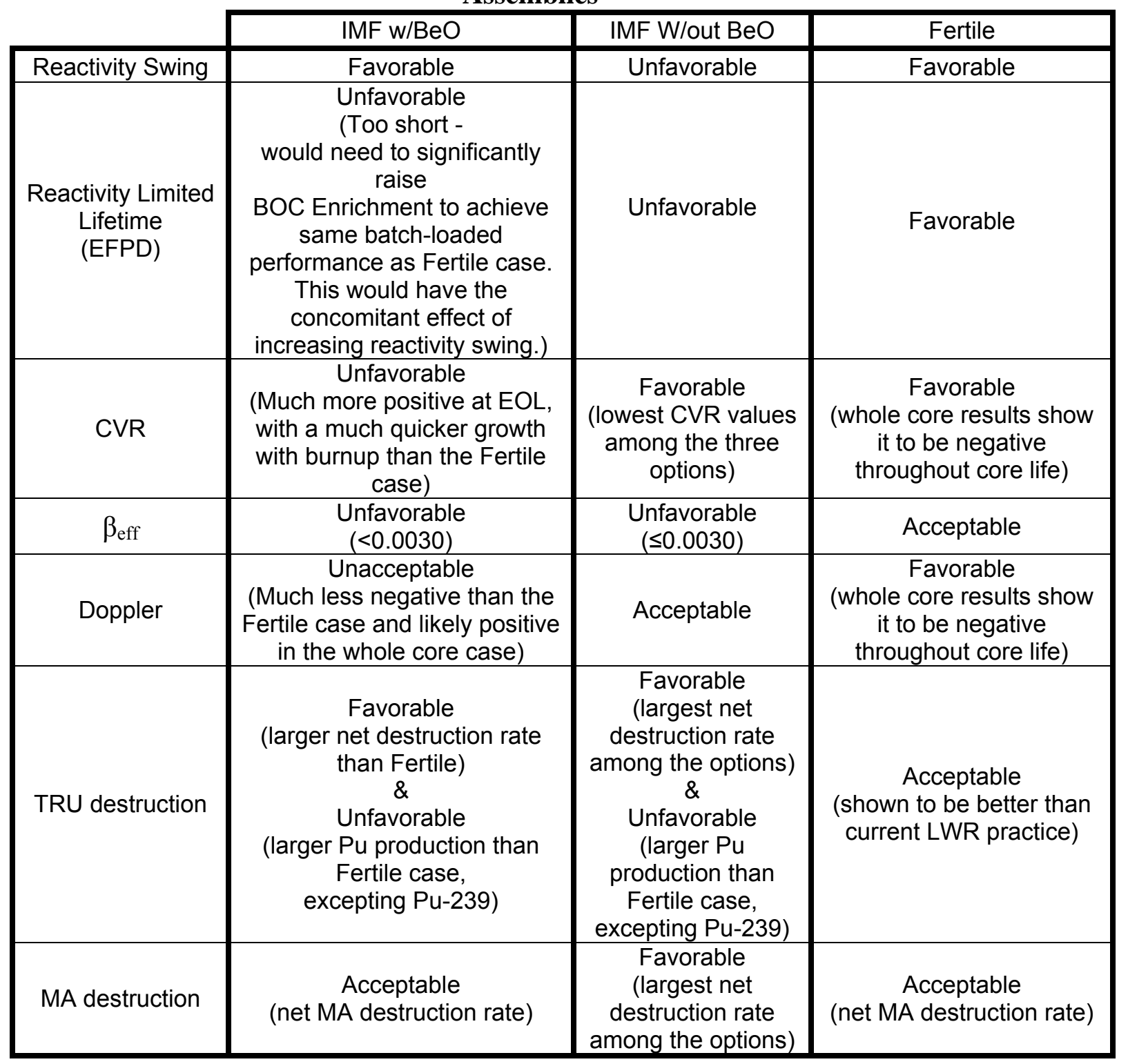

$\mathrm{IMF}=$ Inert Matrix (MgO) Fuel

\subsection{Chapter Summary}

This chapter has summarized the major attributes of a core design which best meets Gen-IV objectives, given the stringent constraints imposed. It shares with the CEA helium cooled GFR the use of somewhat radical, untested features. The MIT $\mathrm{SCO}_{2}$ core employs an inverted fuel unit cell, tube-in-duct (TID) assembly, which has the considerable neutronic advantages of high fuel volume fraction, and is well-suited to venting, which reduces cladding (flow tube) and duct wall stress. We were never able to get a more conventional pin-type core to match TID performance. The modest core 
specific power limits the rate of TRU and/or MA burning, and as will be discussed in Chapter 3, penalizes fuel cycle economics.

1.5 References for Chapter 1 (also see Bibliography in the report introduction)

(1-1) C. S. Handwerk, M. J. Driscoll, P. Hejzlar, "Optimized Core Design of a Supercritical Carbon Dioxide-Cooled Fast Reactor," accepted for publication in Nuclear Technology, December 2008 issue. Scheduled. 


\section{Chapter 2 Task 2: Design of Safety Assurance Systems}

\subsection{Chapter Introduction}

Because of the mediocre heat transfer and transport properties of gases compared to liquid coolants - and especially liquid metals - a GFR must be subjected to special scrutiny with respect to maintenance of core integrity during severe transients. Of particular concern are unprotected sequences involving loss of flow/load/coolant, and transient overpower. One obvious approach is to insure a high level of protection: e.g., highly reliable reactivity insertion and emergency power provision through careful selection of appropriate technology and by the usual strategems of redundancy and diversity. A further guiding principle given widespread credence is the generalization that passive means (e.g., natural convection, gravity, etc.) are to be preferred because of the minimization of more-failure-prone active electro-mechanical components: an initial supposition which was not confirmed for the GFR.

Integration of probabilistic risk analysis (PRA) into the design process has been central to all of our efforts on safety assurance. End results of the process are summarized in this report. More detail in this area is contained in the task-wise reports cited in the introduction, but especially in the final report on the embedded INERI project submitted by MIT/CEA via ANL:

G. E. Apostolakis (MIT), F. Bertrand (CEA), principal investigators, "PRA-Aided Design of Advanced Reactors with an Application to GFR Safety-Related Systems," INERI Project No. 2004-010-F (MIT NERI Project No. 05-044), Final Report, April 22, 2008.

Table 2.0 summarizes key $\mathrm{S}-\mathrm{CO}_{2}$ GFR design features which enhance safety. Subsequent sections of this chapter expand upon the principal features under four major categories: decay heat removal systems (DHRS) design and assessment, improved

emergency power provisions, and scram assurance. Most of the attention is devoted to decay heat removal, since the GFR suffers/differs most in this regard compared to liquidcooled fast reactors, and the latter two areas (backup power and scram reliability) are essentially concept-independent. 
Table 2.0: Safety Assurance for MIT S-CO $\mathrm{CO}_{2}$ GFR

\begin{tabular}{|c|c|c|c|}
\hline DESIGN CHARACTERISTIC & SAFETY IMPLICATION & $\begin{array}{l}\text { ACCIDENTS } \\
\text { AMELIORATED OR } \\
\text { AVOIDED } \\
\end{array}$ & $\begin{array}{l}\text { SUPPORTING } \\
\text { REFERENCES }\end{array}$ \\
\hline $\begin{array}{l}\text { High-Integrity PCIV } \\
\text { - SCS loops inside PCIV } \\
\text { - PCS loop (2@600 MWe each) isolation } \\
\text { \& check valves inside PCIV } \\
\text { - Internal control rod drive mechanisms } \\
\end{array}$ & $\begin{array}{l}\text { - Very low probability of large break in unisolable } \\
\text { pressure boundary } \\
\text { - Eliminates rod ejection accident }\end{array}$ & 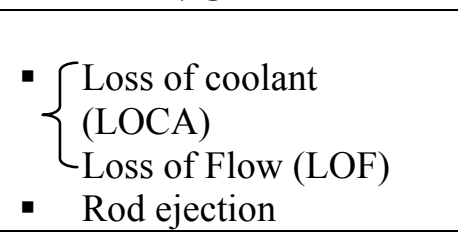 & $(\mathrm{F}-1)$ \\
\hline $\begin{array}{l}\text { 4×50\% SCS/ECCS loops } \\
\text { - Active with passive backup } \\
\text { - Dual use for HTSE applications }\end{array}$ & $\begin{array}{l}\text { - High probability of success } \\
\text { - Water boiler loops are self-powered, always on }\end{array}$ & $\cdot\{$ LOCA & $\begin{array}{l}(\mathrm{P}-2) \\
(\mathrm{M}-1)\end{array}$ \\
\hline $\begin{array}{l}\text { Robust (PWR-type) containment } \\
\text { - } 17 \text { Atm can cool core by natural } \\
\text { convection } \\
\text { - Filtered/vented to facilitate pressure } \\
\text { control } \\
\text { - } \text { Can add } \mathrm{CO}_{2} \text { from PCS makeup system }\end{array}$ & $\begin{array}{l}\text { - Buys time for activation of forced convection in } \\
\text { SCS loop } \\
\text { - Eliminates over-pressurization risk } \\
\text { - Extends duration of SCS passive mode, } \\
\text { compensates for containment leakage and/or } \\
\text { cooldown }\end{array}$ & $\begin{array}{l}\text { - }\left\{\begin{array}{l}\text { Loss of off-site power, } \\
\text { station blackout }\end{array}\right. \\
\text { - Containment failure } \\
\text { - Loss of power to SCS }\end{array}$ & $(\mathrm{P}-1)$ \\
\hline $\begin{array}{l}\text { Diverse \& redundant emergency power } \\
\text { - Diesels plus fuel cells } \\
\text { - Two independent main PCS loops, } \\
\text { including turbo-generators } \\
\text { - Can run generator as motor }\end{array}$ & $\begin{array}{l}\text { - Fuel cells can operate in constant-on mode } \\
\text { - Greater assurance of on-site power } \\
\text { - Can dump heat via PCS precooler }\end{array}$ & $\begin{array}{l}\text { - SCS failure to start and/or } \\
\text { diagnosis of faults } \\
\text { - }\left\{\begin{array}{l}\text { Station blackout } \\
\text { Loss of load }\end{array}\right. \\
\text { - Same as SCS }\end{array}$ & $(\mathrm{A}-1)$ \\
\hline $\begin{array}{l}\text { Forgiving core design } \\
\text { - Negative void reactivity } \\
\text { - IFR type quasistatic inherent asymptotic } \\
\text { reactivity compensation } \\
\text { - Can incorporate passive high T/low P } \\
\text { reactivity insertion devices } \\
\text { - Low power density for a fast reactor } \\
\text { - Two independent, diverse control rod and } \\
\text { scram systems } \\
\text { - Water flooding reduces reactivity (and } \\
\text { cools core) }\end{array}$ & $\begin{array}{l}\text { - Avoids large reactivity insertion during LOCA } \\
\text { - No need for rapid response by active systems or } \\
\text { operators } \\
\text { - Helps rule out ATWS events } \\
\text { - Slower core heatup in overpower transients=more } \\
\text { time for amelioration } \\
\text { - Insures active scram, avoids common mode } \\
\text { failures } \\
\left\{\begin{array}{l}\text { Reduces significance of SCS and precooler water } \\
\text { leaks }\end{array}\right. \\
\text { Could also be safety feature of last resort }\end{array}$ & $\begin{array}{l}\text { - Prompt criticality } \\
\text { - All upsets \& accidents } \\
\text { - LOCA, loss of flow, } \\
\text { transient overpower } \\
\text { - } \begin{array}{l}\text { Transient overpower, e.g. } \\
\text { control rod withdrawal }\end{array} \\
\text { - Failure to scram, ATWS } \\
\text { - } \begin{array}{l}\text { Core loss of geometry, } \\
\text { meltdown, recriticality }\end{array}\end{array}$ & $\begin{array}{l}(\mathrm{H}-1) \\
(\mathrm{D}-1)\end{array}$ \\
\hline
\end{tabular}




\section{References for Table 2.0}

\begin{tabular}{|c|c|}
\hline$(\mathrm{A}-1)$ & $\begin{array}{l}\text { D. Akkaynak et al, "Use of Fuel Cells to Power a High-Reliability GFR ECCS," Trans. } \\
\text { Am. Nucl. Soc., Vol. 93, Nov. } 2005\end{array}$ \\
\hline (H-1) & $\begin{array}{l}\text { C.S. Handwerk, M.J. Driscoll, P. Hejzlar, "Use of Beryllium Oxide to Shape Power and } \\
\text { Reduce Void Reactivity in Gas Cooled Fast Reactors," PHYSOR } 2006\end{array}$ \\
\hline$(\mathrm{P}-1)$ & $\begin{array}{l}\text { M.A. Pope, P. Hejzlar, M.J. Driscoll, “Thermal Hydraulics of a } 2400 \text { MWth } \\
\text { Supercritical } \mathrm{CO}_{2} \text { Direct Cycle GFR,” MIT-ANP-TR-112, Sept. } 2006\end{array}$ \\
\hline$(\mathrm{F}-1)$ & $\begin{array}{l}\text { L.B. Fishkin, "Prestressed Cast Iron Vessel (PCIV) Use for GEN-IV GFR } \\
\text { Applications," MIT-GFR-006, April } 2004\end{array}$ \\
\hline$(\mathrm{P}-2)$ & $\begin{array}{l}\text { M.A. Pope, M.J. Driscoll, P. Hejzlar, "Shutdown/Emergency Cooling System for a } 2400 \\
\text { MWth Supercritical } \mathrm{CO}_{2} \text { Cooled Direct-Cycle GFR," ICAPP ‘06 }\end{array}$ \\
\hline (D-1) & $\begin{array}{l}\text { M.J. Driscoll, C.S. Handwerk, “Tests of a Flow-Levitated Absorber for GFR LOF and } \\
\text { LOCA Mitigation,” Trans. Am. Nucl. Soc., Vol. 94, June } 2006\end{array}$ \\
\hline (M-1) & $\begin{array}{l}\text { M.J. Memmott, M.J. Driscoll, P. Hejzlar, "Synergistic Configuration of a GFR for } \\
\text { Hydrogen Production by Steam Electrolysis," Trans. Am. Nucl. Soc., Vol. 95, Nov. } \\
2006\end{array}$ \\
\hline
\end{tabular}

\subsection{Decay Heat Removal}

\subsubsection{Some General Aspects of Core Cooling}

Vulnerability to fuel, and more specifically cladding, overheating is commonly regarded as the Achilles' heel of GFR concepts. The high ratio of specific power to heat capacity leads to much faster temperature excursions than in gas-cooled thermal reactors. This puts increased emphasis on rapid shutdown followed by efficacious decay heat removal. Table 2.1 shows the functional dependence of heat removal capability on some important parameters. As can be seen, natural convection (hence passive) cooling is directly proportional to pressure. Thus extraordinary measures are justified to prevent total depressurization. In the present case this is addressed by providing for isolation of broken or leaking power cycle loops, backed up by a robust containment capable of sustaining a post-LOCA pressure of $7 \mathrm{~atm}$. Efficacy is facilitated by the use of $\mathrm{CO}_{2}$ coolant, which is nearly three times better than He. Time also plays an important role. As shown in Fig. 2.1, after three or four days, natural convection will suffice even at one atmosphere of ambient pressure.

These basic considerations also help explain the preoccupation with LOCA events, and a lower level of concern over LOF, since under no-flow conditions, primary system pressure equilibrates to about $14 \mathrm{MPa}$, at which natural convection could remove as much as $15 \%$ of full power. 


\section{Table 2.1: Thermal-Hydraulic Scaling Relations for GFR Core Cooling}

- Forced Convection Circulator Power, W (at fixed thermal fields, gas pressure):

o $W \propto Q^{3}$, both turbulent and laminar where $\mathrm{Q}$ is core thermal power (at fixed thermal fields, core power)

o $W \propto P^{-2}$, where $\mathrm{P}$ is gas pressure

Thus doubling $\mathrm{Q}$ increases $\mathrm{W}$ by factor of 8 ; and doubling $\mathrm{P}$ reduces $\mathrm{W}$ by factor of 4

- Forced Convection Heat Removal Capability, Q

o Fixed thermal fields, circulator power: $Q \propto P^{2 / 3}$

Thus doubling $\mathrm{P}$ increases $\mathrm{Q}$ by $\sim 60 \%$

o Fix W, vary gas type: $Q \propto C p M^{2 / 3}$, both turbulent and laminar where $\mathrm{M}$ is molecular weight, hence $\frac{Q_{\mathrm{CO}_{2}}}{Q_{\mathrm{He}}} \approx 1.2$

- Natural Convection (fixed thermal fields)

o $Q \propto P^{1.0} H^{1 / 2}$, where $\mathrm{H}$ is vertical distance between heat source and sink thermal centers

o $Q \propto C p M$, where $\mathrm{M}$ is molecular weight, hence $Q_{\mathrm{CO}_{2}} / Q_{\mathrm{He}} \simeq 2.6$

in which:

$\mathrm{Q}=$ core thermal power

$\mathrm{W}=$ circulator power needed

$\mathrm{P}=$ gas pressure

$\mathrm{Cp}=$ gas heat capacity $\left(\mathrm{J} / \mathrm{kg}^{\circ} \mathrm{C}\right)$

$\mathrm{M}=$ molecular weight of gas

$\mathrm{H}=\quad$ vertical distance between thermal centers: heat sink - heat source 
t, Time, Hours

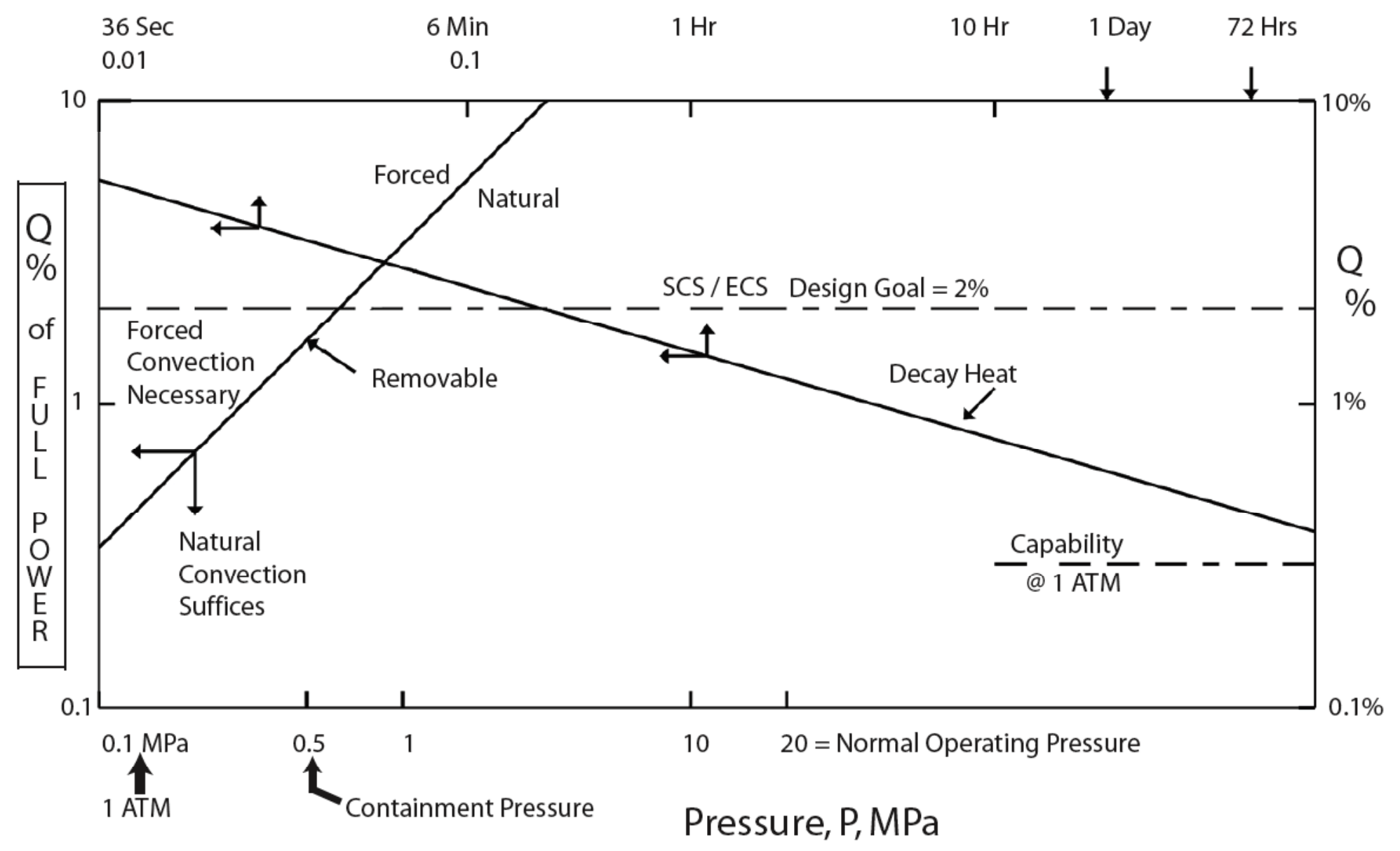

Removable by Natural Convection: $\mathrm{Q}=\mathrm{C} \cdot \mathrm{P}^{1.0},(\mathrm{C}=$ System - Specific Parameter $\approx 3 \%)$

Decay Heat Generation: $\quad \mathrm{Q}=\frac{0.0147}{\mathrm{t}^{0.28}},(\mathrm{t}$ in hours $)$

Fig. 2.1: Map of Shutdown Cooling Operating Regimes 


\subsubsection{Loss of Coolant Accidents}

Figure 2.2 shows, in cartoon form, what happens during cold or/and hot PCS duct breaks, with/without isolation, in the short term. As noted, some sequences involve core flow reversal due to the drop in core inlet plenum pressure. Others allow core bypass. All set up a unique set of boundary conditions for subsequent DHRS startup. The interplay between these conditions and the initial DHR loop conditions can lead to longer term underperformance. The large number of combinations also suggests a multi-scenario Monte Carlo simulation. 
Figure 2.2: Cartoons showing consequences of isolation failure in a Single-loop LOCA (3 pages)

I Cold leg break (non coaxial ductwork)

(1) No isolation

One PCS loop (of 2)

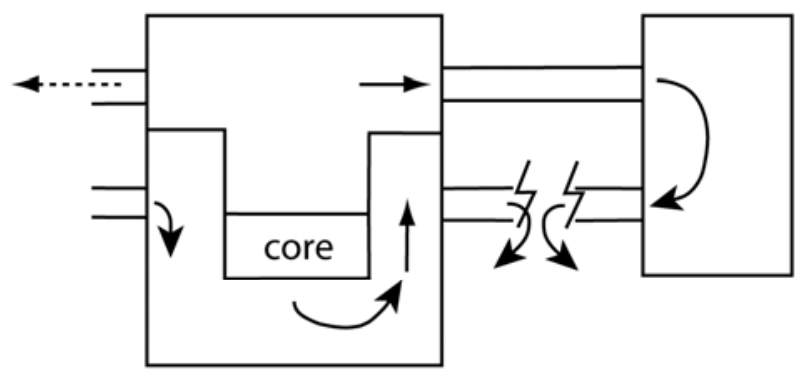

* Double-ended blowdown of entire inventory

* Core flow bypass/reversal/ stagnation

(2) Hot leg isolation

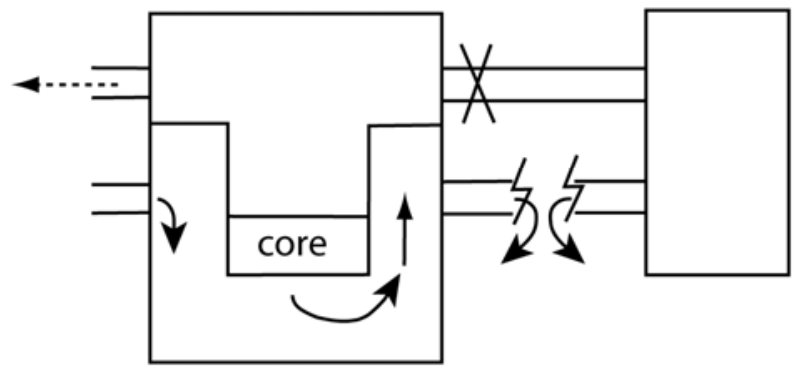

(3) Cold leg isolation

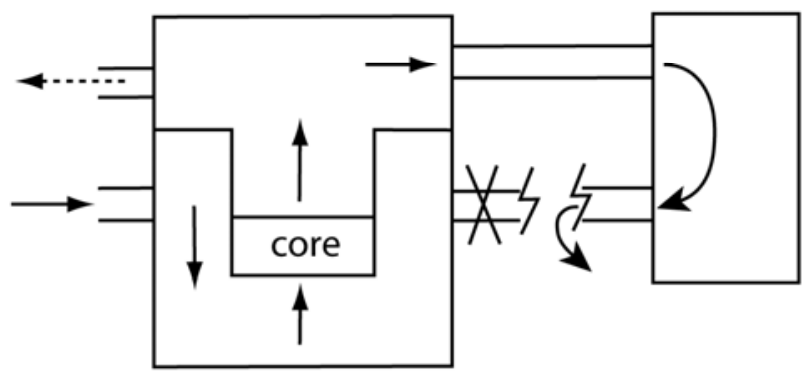

(4) Both legs isolated

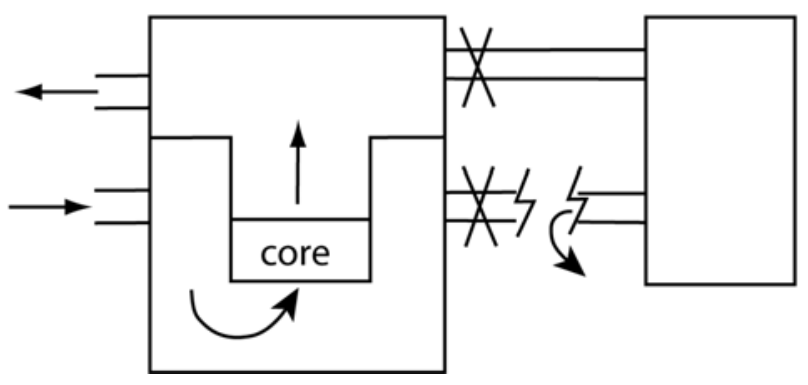

* Double-ended blowdown initially; later single-ended blowdown of rest of entire inventory

* Core flow bypass/reversal/ stagnation

* Single-ended blowdown (hence slower), of entire inventory

* No core flow reversal

* Single-ended blowdown confined to 1 PCS (of 4)

* No flow reversal: Other 3 PCS functional; system pressure maintained 
II Hot leg break

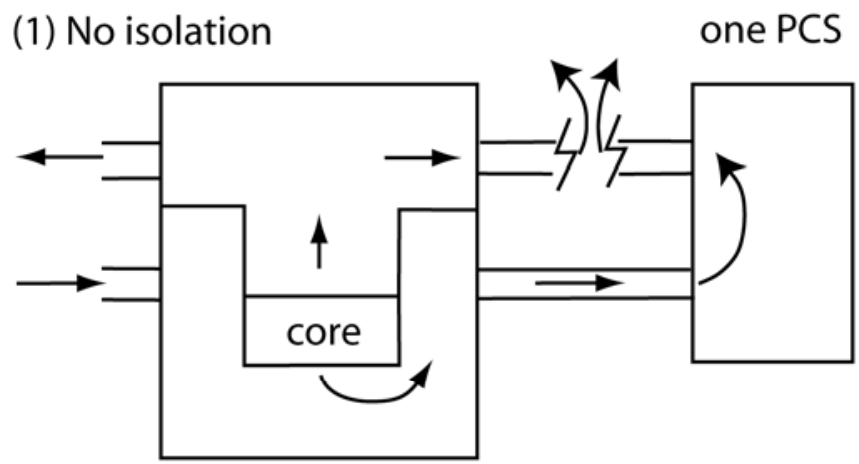

* Double-ended blowdown of entire inventory

* PCS flow resistance mitigates core bypass

(2) Hot leg isolation

PCS

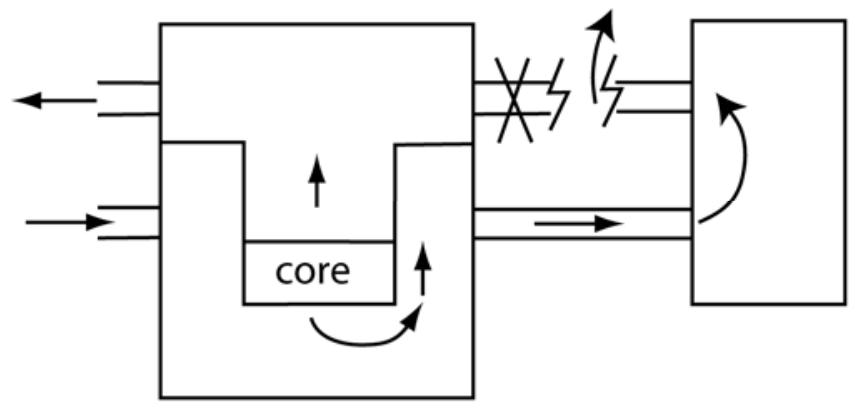

* Single-ended blowdown of entire inventory

* PCS flow resistance mitigates core bypass

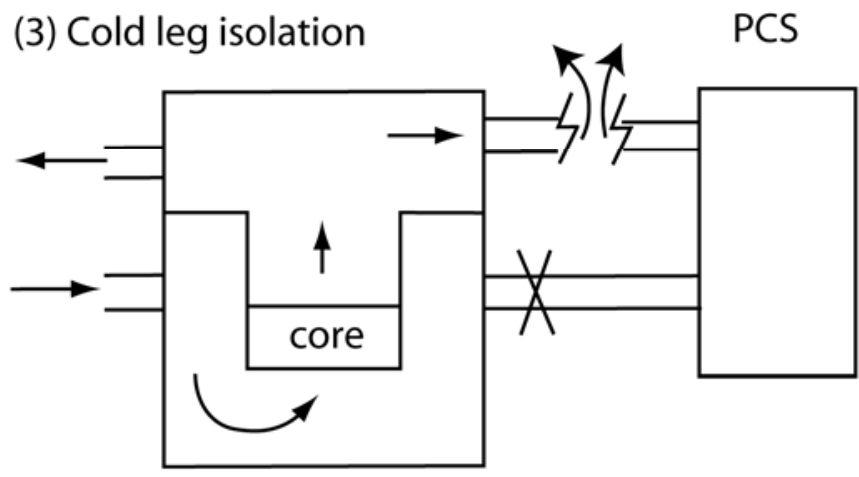

* Double-ended blowdown initially, later single

* No core flow reversal

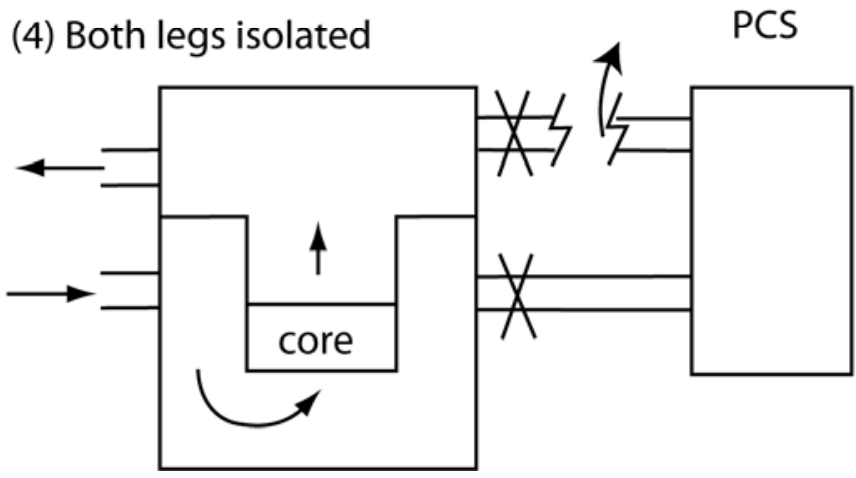

* Single-ended blowdown confined to one PCS

* No flow reversal system pressure maintained 
III Both legs break (e.g., as for coaxial duct)

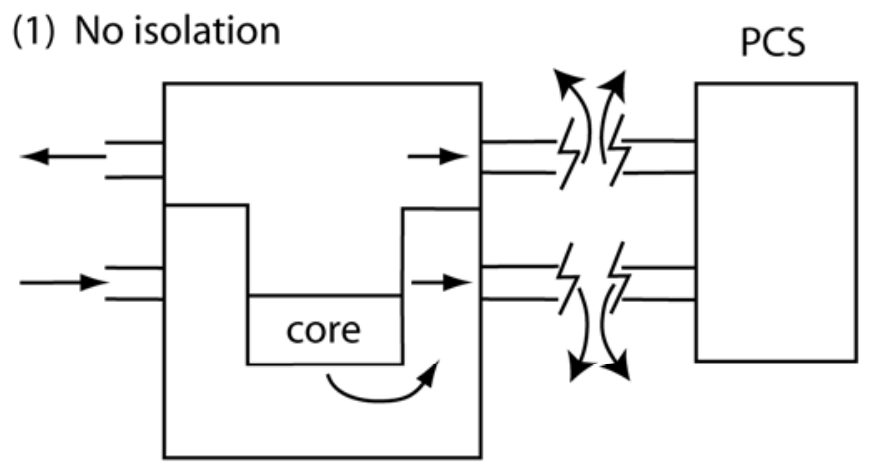

* Four-ended blowdown initially, two later

* Core bypass likely (enveloping worst case)

(2) Hot leg isolation

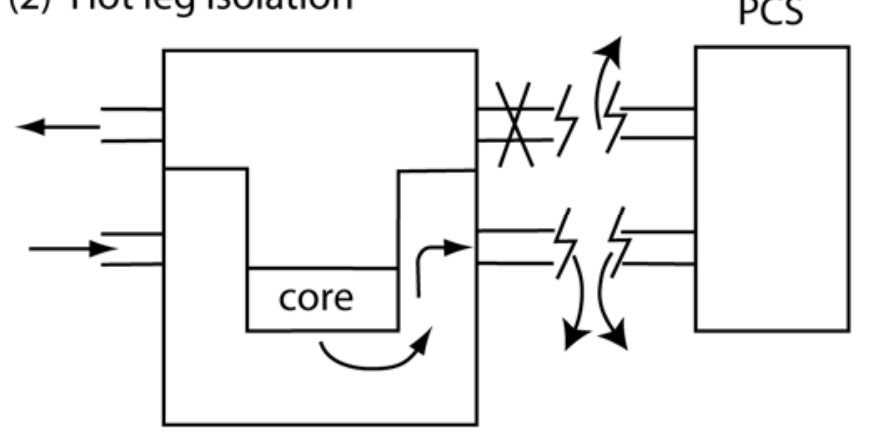

* 3-ended blowdown initially, one later

* Core flow reversal

(3) Cold leg isolation

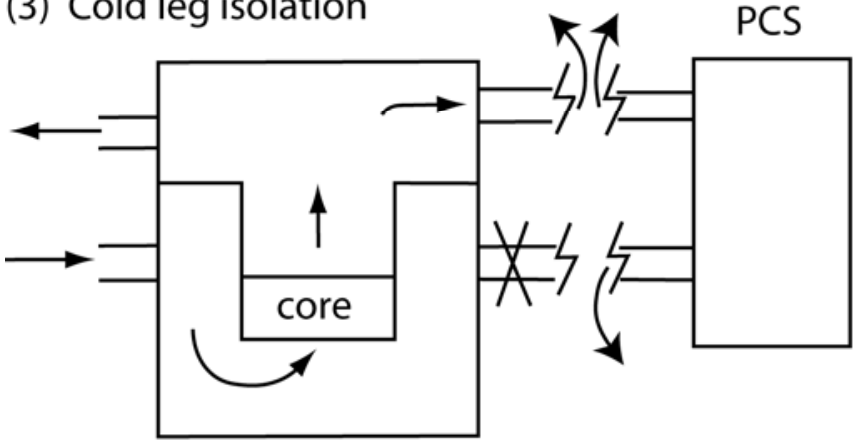

*3-ended blowdown initially, one later

* No core flow reversal

(4) Both legs isolated

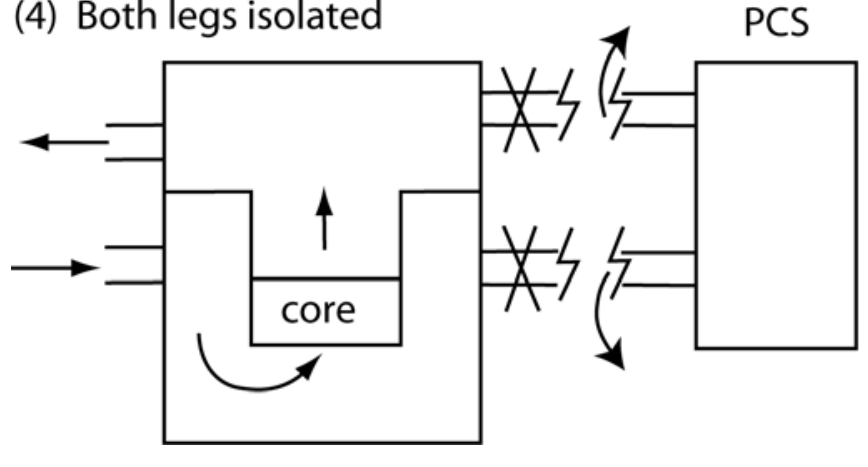

* Double-ended blowdown confined to one PCS

* No flow reversal, system pressure maintained 
Large motor-operated valves have traditionally been assigned a median failureper-activation probability of $10^{-4}$; and check valves another order of magnitude smaller. Thus LOCAs in which both the hot and cold legs are left open are too infrequent to merit credible concern. Similarly, if the cold leg contains both check and isolation valves, cold leg isolation is adequately assured. This also precludes core bypass/flow reversal/stagnation. Hence reference case LOCA analyses should focus on a hot leg break near the vessel with failure to isolate the hot leg. This is more severe (faster blowdown) than a cold line break (with cold line isolation) due to the flow resistance of the PCS.

\subsubsection{Post-Blowdown Core Cooling}

Following the scenarios postulated in Fig. 2.2, and assuming the broken loop can not be expeditiously isolated, the pressure throughout falls to the uniform containment design pressure $(\sim 0.7 \mathrm{MPa})$. At this point the core inlet and outlet pressures equalize, and the check valves in the DHR loops should open to initiate natural convection cooling. However, as shown in Fig. 2.3, reverse flow in one or more loops can actually take place because of adverse initial conditions. This is especially true for DHR layouts in which the heat exchangers are outside of the reactor pressure vessel, and connected to it by coaxial ducts: as was the case in the original helium cooled studies undertaken in the present work. Use of $\mathrm{CO}_{2}$ and loops inside the pressure vessel, as in our final version, should greatly reduce the likelihood of off-normal patterns of circulation. Nevertheless, principal reliance on actively-induced circulation using blowers (not shown in Fig. 2.3), is still preferred because of the overriding need for ultra-high reliability. At the minimum, blower start will create a pressure differential which will help insure check valve opening, and startup of flow in the correct direction, following which natural convection alone would suffice. 


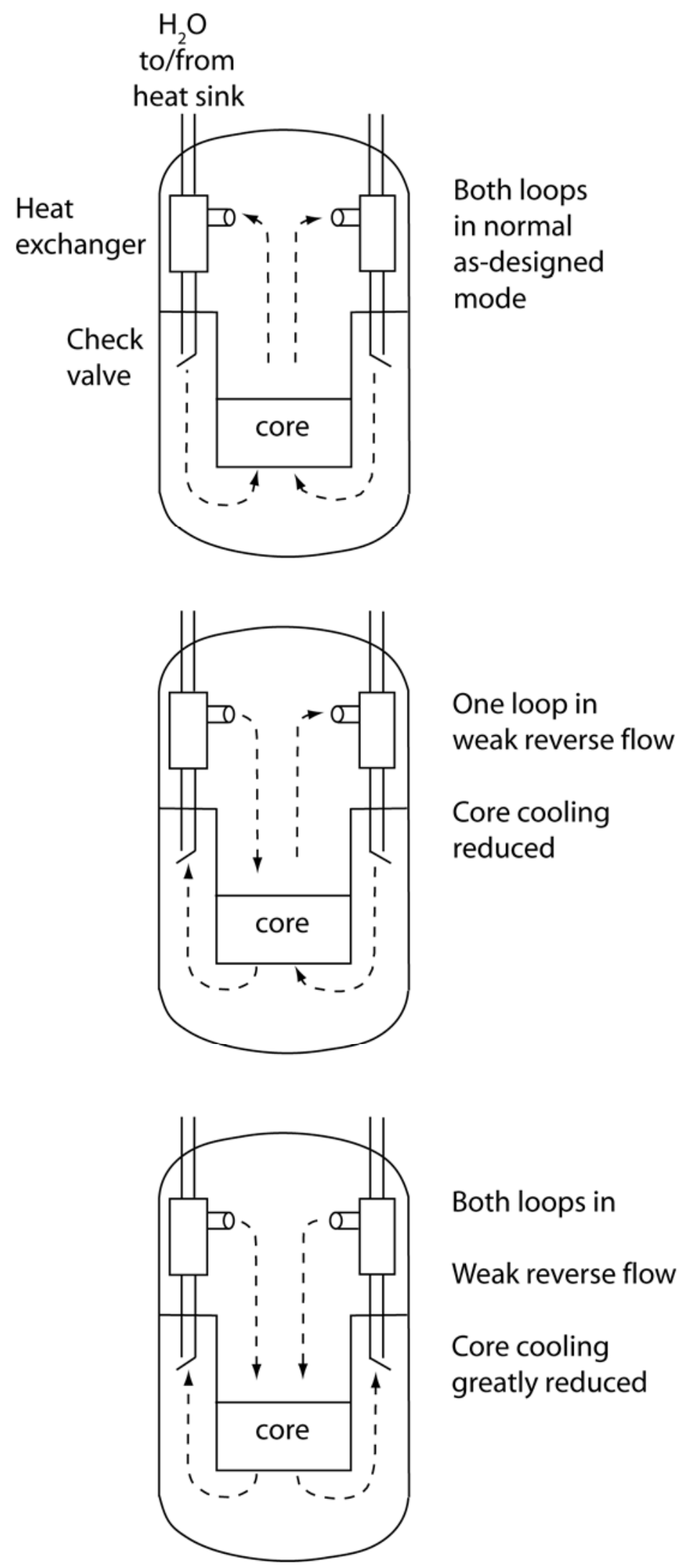

Figure 2.3: DHR Loop Natural Convection Flow Paths Seen in RELAP Simulations 


\subsubsection{Evolution of Decay Heat Removal System (DHRS) Design}

The DHRS evolved through several successive versions:

(1) A carry-over design from our involvement with a US - French CEA INERI, which accordingly involved helium coolant. See Fig. 2.4 for a schematic.

(2) An initial NERI project design, basically the same, but with a change to $\mathrm{CO}_{2}$ coolant. In particular, the DHRS loops were still outside the core pressure vessel. See Fig. 2.5 for a schematic.

(3) Variations on the theme, for example using circulating water rather than boiling water in the ultimate heat sink exchanger; and placement of the intermediate gas-to-water heat exchanger inside the prestressed cast iron vessel (PCIV) used in the MIT S-CO $\mathrm{CO}_{2}$ GFR design. See Fig. 2.6 for a schematic.

(4) Finally, a special case was investigated for reactors designed to produce hydrogen by high temperature steam electrolysis (HTSE). It was shown that the loops needed to generate steam for the electrolysis cells can do double-duty as DHRS loops, and furthermore that a self-powered version can be devised. See the separate discussion in section 3.2 of Chapter 3. 


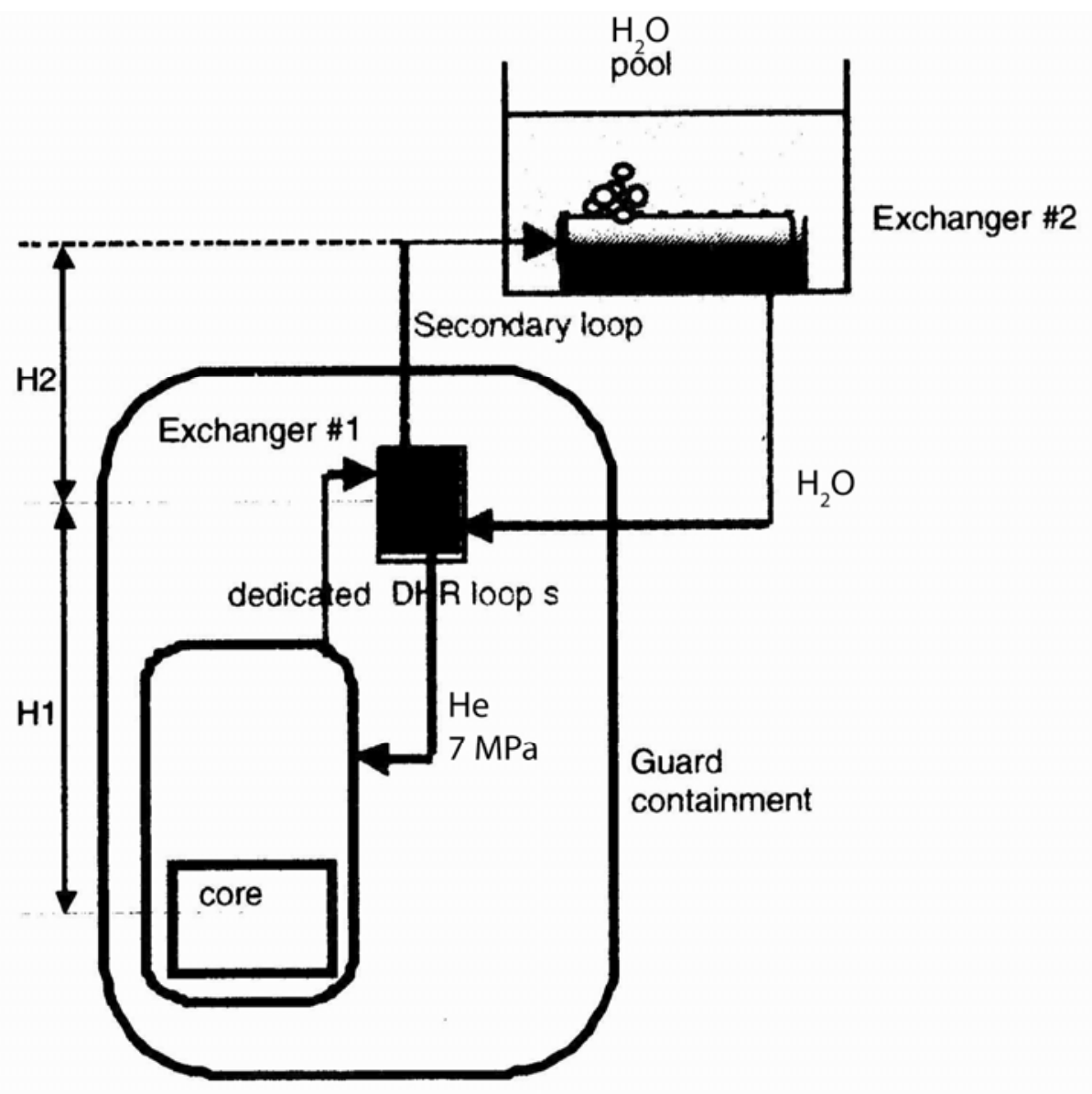

Figure 2.4: Schematic of the CEA GFR DHR Loop Layout (1 of $3 \times 100 \%)$ (from Ref 2-3) 


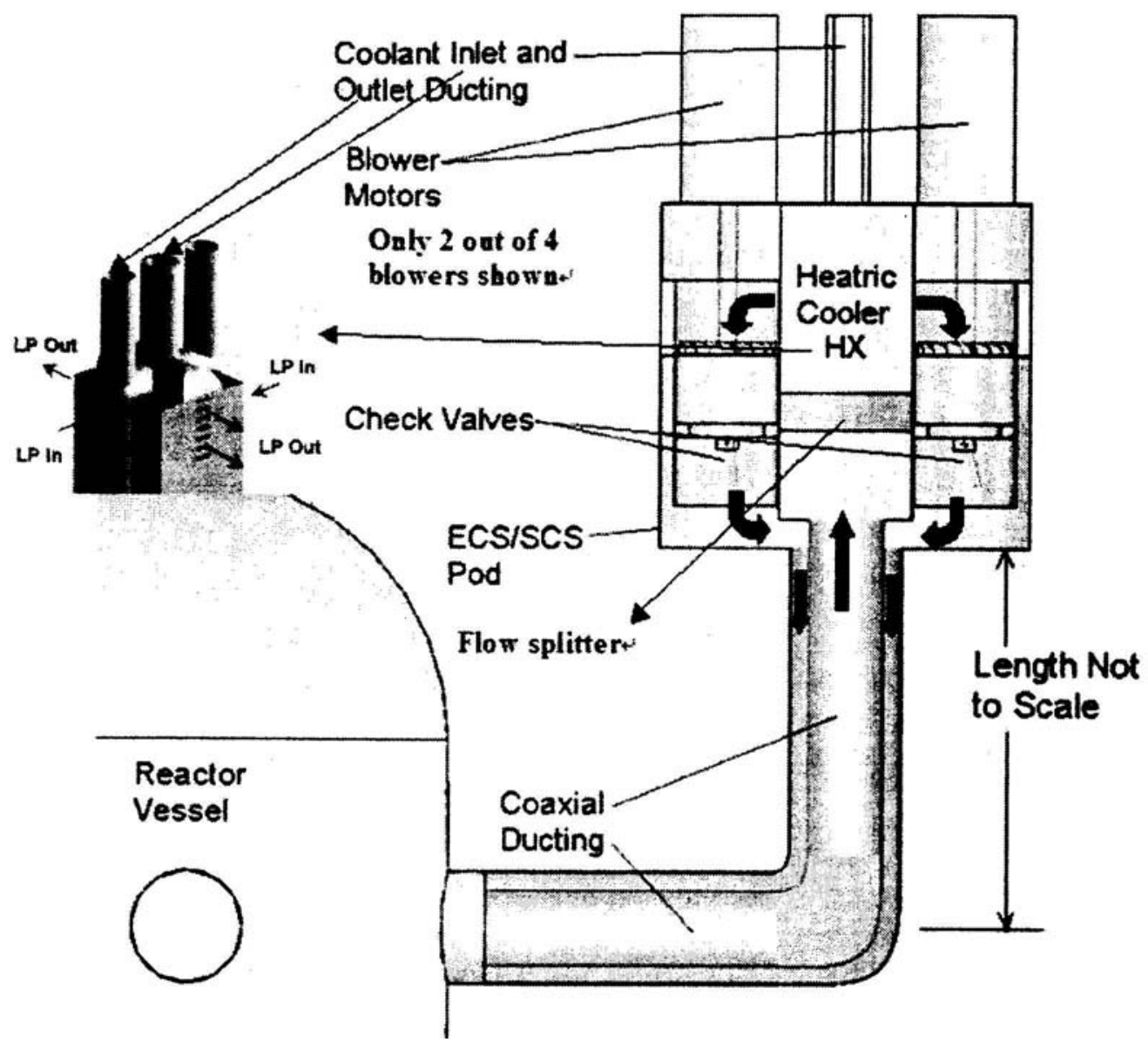

Figure 2.5: SCS Loop with HEATRIC ${ }^{\mathrm{TM}} \mathrm{HX}$ 


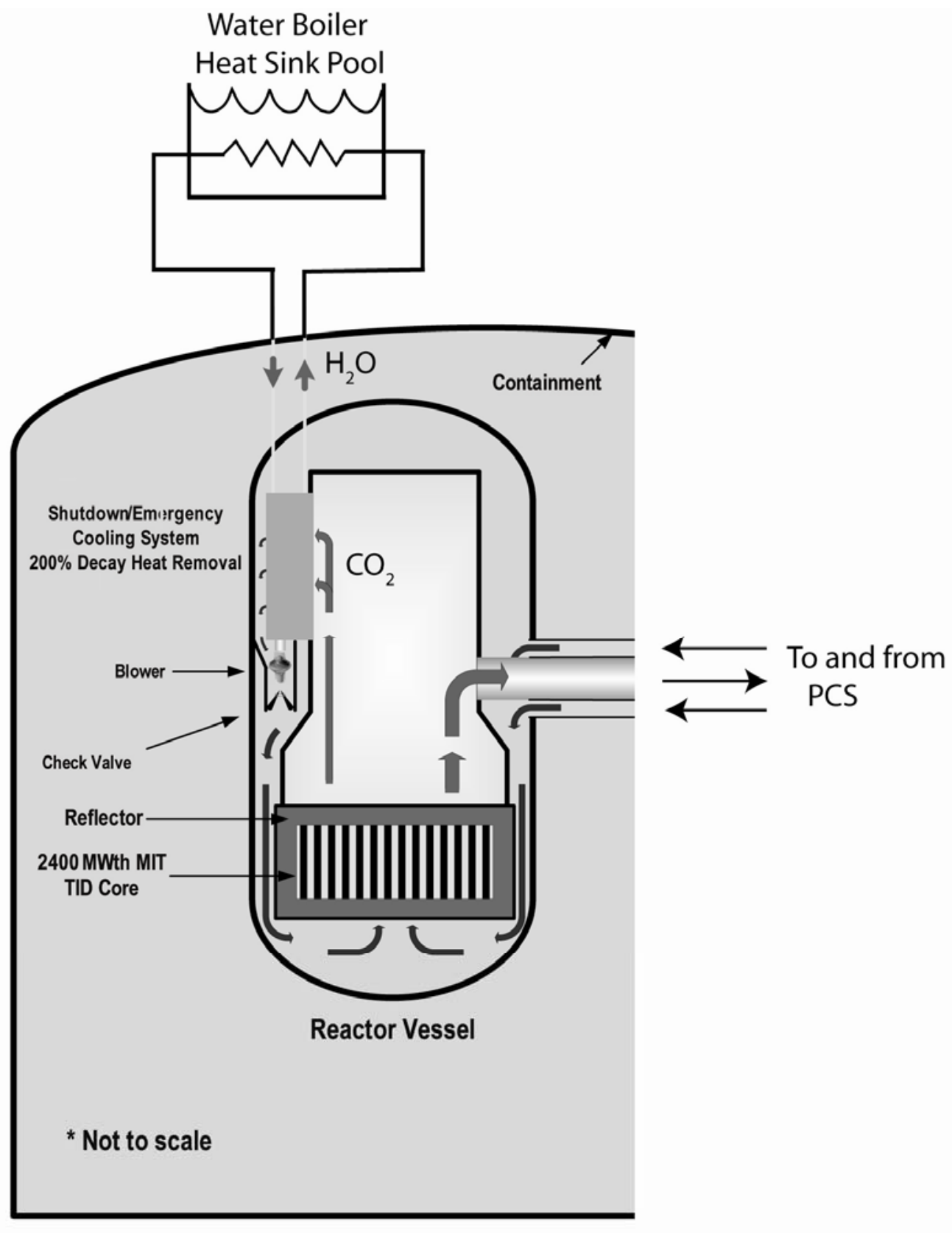

Figure 2.6: Layout of MIT GFR DHR Loops (1 of 4 x 50\%)

As noted above, the gas-to-water heat exchanger is inside the PCIV, to eliminate the ability of these loops to cause a reactor coolant LOCA. Earlier versions of this system employed a water-to-water heat sink exchanger instead of a water-boiler heat dump (with a dry cooling tower as the ultimate heat sink). Both approaches are feasible, but the water-boiler version is simpler, and allows 72 hours of passive operation, whereas the pumped water versions need emergency power - which could be batteries because of the low power demand. 
To further protect against severe LOCA consequences, the main PCS loops are equipped with isolation (and/or check) valves located inside the PCIV (or immediately at the vessel/PCS duct interface): features not shown in the schematics. Prompt isolation can interrupt a LOCA before severe depressurization, in which case DHRS operation in the natural circulation mode is, in principle, fully capable of core protection - assuming flow in the DHRS assumes its steady-state direction. In fact, parametric studies confirm that DHR heat removal under natural circulation increases in direct proportion to gas pressure. They also confirm that $\mathrm{CO}_{2}$ is superior to He because of the higher density of $\mathrm{CO}_{2}$. Note that the CEA has provided for the injection of heavier gas from $\mathrm{N}_{2}$ accumulators to exploit this effect. Both the CEA and MIT call for robust containments to keep minimum post LOCA pressure high (CEA@1.0 MPa, MIT @0.7 MPa). In the MIT design, the PCS or containment pressure can be increased by injecting $\mathrm{CO}_{2}$ from the PCS coolant storage system, which contains $150 \%$ of its inventory at an average pressure of $14 \mathrm{MPa}$.

As with the main PCS loops, the DHRS loops must be isolatable using stop and/or check valves, to avoid core bypass and to protect against leakage backflow (which can frustrate startup).

For the DHRS loops employed for Post-LOCA/normal shutdown/refueling cooling, which are in parallel with the primary coolant flowpath, there are three flow bypass issues:

\section{(1) By-Pass of the Core During Normal Operation}

Normally the inlet downcomer and plenum are at higher pressure than the core outlet pressure. If the DHRS is inadvertently/accidentally actuated, backflow through the DHRS can by-pass the core. Moreover, leaky check valves can allow continuous reverse flow through a DHRS loop during normal operation. This results in hot leg temperatures lower than in the cold leg, making startup of natural circulation difficult.

(2) By-Pass of the DHRS Itself

If in a LOCA the main coolant loop fails in such a way as to provide a low resistance path venting into the containment space, the flow could avoid circulation through the DHRS.

(3) By-Pass of Containment

This might occur due to failure of DHRS heat exchanger tubing, piping or isolation valves, depending on design details.

Accordingly careful attention must be paid to all failure modes and especially valving: check and isolation; their location, number, and mode of actuation.

A minimum guiding principle should be that no single failure can lead to by-pass

Another key choice was the number of DHRS loops. Here elementary probabilistic calculations proved useful. Table 2.2 shows one such example. While the MIT choice of $4 \times 50 \%$ capability is less failure-proof than the CEA $3 \times 100 \%$ arrangement, both are extremely reliable, and the difference narrows when common 
mode failures are included in the analysis. Also note that if the post-LOCA pressure is doubled, the $4 \times 50 \%$ design becomes $4 \times 100 \%$. Figures 2.7 and 2.8 show failure probability as a function of single loop failure probability.

Table 2.2: Failure of Protective Function for DHRS Layout

$$
F=\left[\frac{n !}{(n-m) ! m !}\right] P_{1}^{m}\left(1-P_{1}\right)^{(n-m)}
$$

where $\mathrm{F}=$ failure probability of ensemble

$\mathrm{n}=$ number of parallel systems

$\mathrm{m}=$ number which must fail to cause failure of protection

hence

$$
\begin{aligned}
& \mathrm{r}=\mathrm{n}-\mathrm{m}+1, \text { number of parallel systems } \\
& \text { which must work }
\end{aligned}
$$

\begin{tabular}{llll|l|l} 
& & & & \multicolumn{2}{|c}{$\mathrm{F}$ for $\mathrm{P}_{1}=$} \\
$\mathrm{n}$ & $\mathrm{C} \%$ & $\mathrm{~m}$ & $\mathrm{r}$ & $10^{-2}$ & $10^{-3}$ \\
\hline 1 & 100 & 1 & 1 & $10^{-2}$ & $10^{-3}$ \\
2 & 100 & 2 & 1 & $10^{-4}$ & $10^{-6}$ \\
4 & 33 & 2 & 3 & $6 \times 10^{-4}$ & $6 \times 10^{-6}$ \\
$4^{*}$ & 50 & 3 & 2 & $4 \times 10^{-6}$ & $4 \times 10^{-9}$ \\
3 & 50 & 2 & 2 & $3 \times 10^{-4}$ & $3 \times 10^{-6}$ \\
$3 * *$ & 100 & 3 & 1 & $10^{-6}$ & $10^{-9}$ \\
4 & 100 & 4 & 1 & $10^{-8}$ & $10^{-12}$
\end{tabular}

* Recommended configuration

** CEA GFR configuration 


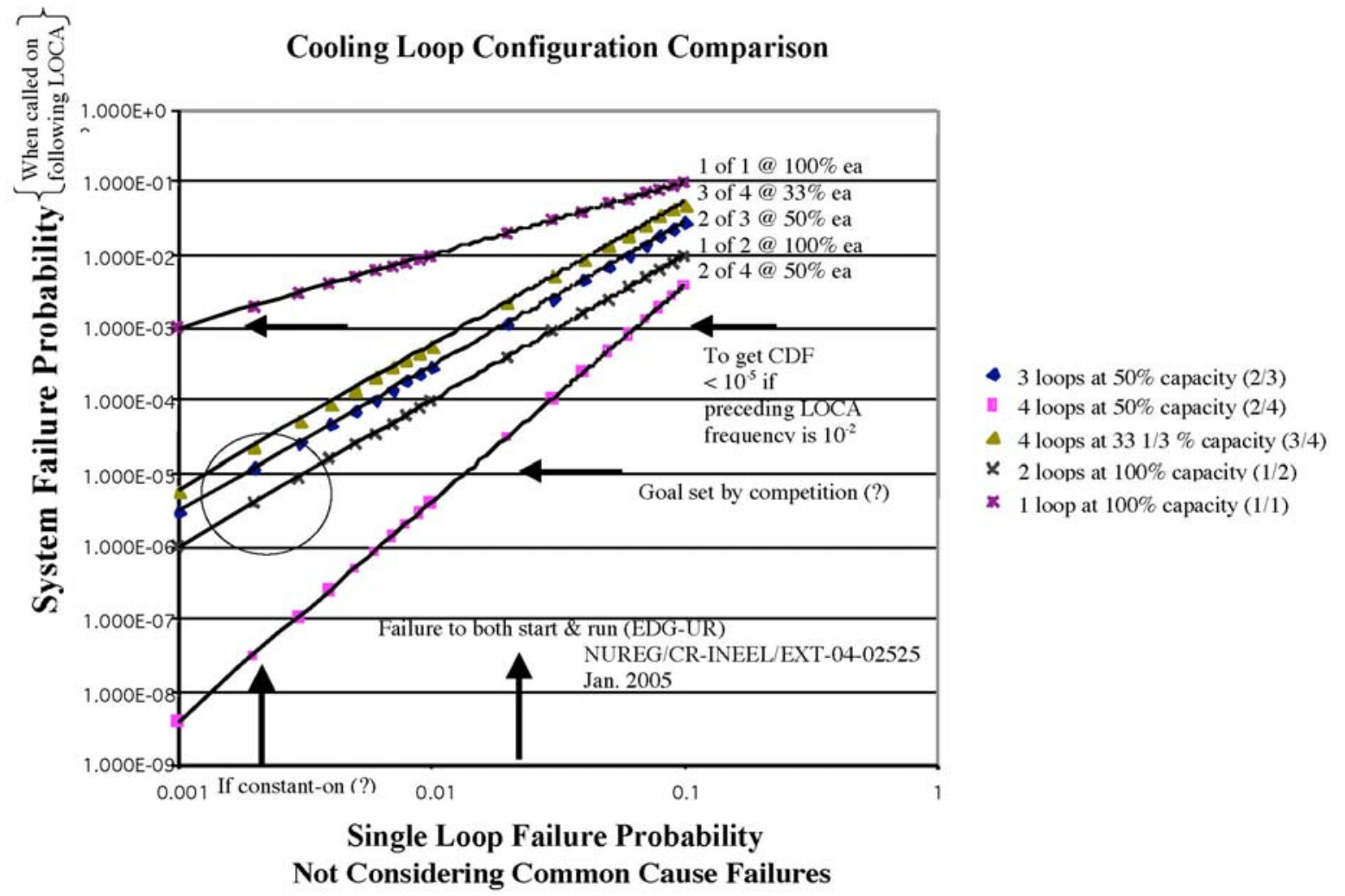

Figure 2.7: Overall System Functional Failure as a Function of Single Loop Unreliability

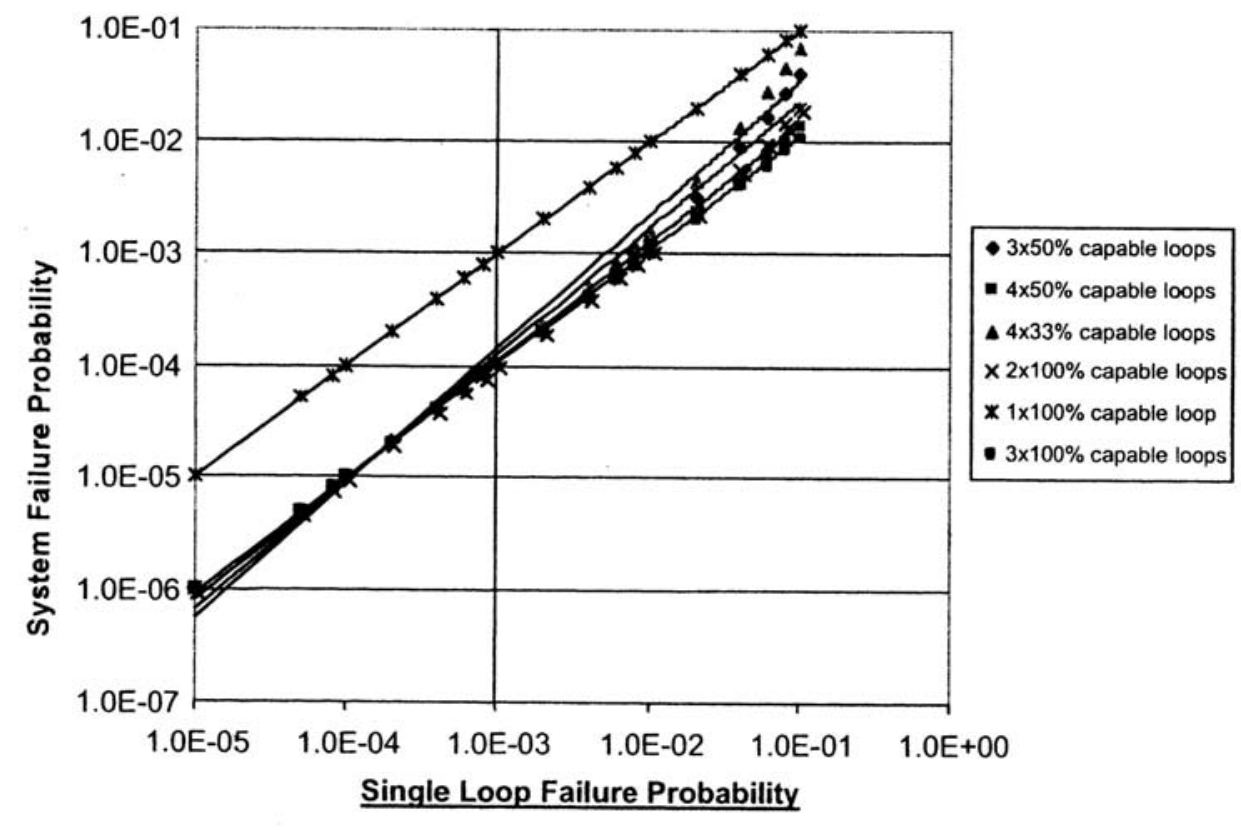

Figure 2.8: Comparison of Failure Probability for Auxiliary Cooling Loop Options with Common Cause Failures

$($ Common Cause Failures modeled with Beta factor $=0.1)$ 


\subsubsection{RELAP Simulations}

\subsubsection{RELAP Simulations of Helium-Cooled GFR (INERI work)}

As part of task 2, simulations of passive system decay heat removal were carried out for a helium-cooled GFR core (2-5). This work was also a principal contribution to the INERI project (No. 2004-010-F) between the US and the French CEA. (Ref 2-1)

A two-loop DHR configuration was modeled using RELAP5-3D. Then, using key parameter values selected from probability distributions, a series of several dozen runs was made to calculate post-LOCA behavior. Figure 2.9 shows maximum clad temperature as a function of elapsed time. As can be seen, some histories violate the $1600^{\circ} \mathrm{C}(1873 \mathrm{~K})$ limit. The results were then analyzed to arrive at several important insights.

(a) Check valve pre-accident leakage and/or post-LOCA failure to actuate are major failure modes.

(b) Two (or more) parallel loop simulation is essential, since n-loop decay heat removal is not simply $n$ times that of a single loop. In fact, situations arise where backflow can occur through one loop to create a path where coolant bypasses the core.

(c) Performance can be improved by obvious measures, such as improving check valve reliability, and less-obvious modifications such as strategic placement of insulation in DHR ductwork - especially where coaxial.

(d) $\mathrm{CO}_{2}$ is superior to $\mathrm{He}$ : loop circulation is enhanced and functional failures reduced.

It is important to note that the RELAP models of the DHRS loops are all very similar, and not sensitive to minor differences in configuration, except where noted, as in the case of ductwork insulation. Sensitivity studies confirmed that the choice of gas, its pressure and thermal height (core center to heat sink) dominated most other variables for steady state performance. Furthermore, once a near-steady-state flow pattern and temperature field representative of normal operation are established, natural convection will continue without the need for supplementary forced convection. It is the failure to start properly under pure natural convection with non-negligible probability that led to the decision to make active (blower-driven) DHRS operation the preferred mode, but with fully-capable passive (natural convection) mode as backup.

A second reason for favoring forced convection is the propensity of gas to drift into a deteriorated heat transfer regime (see Section 2.1.6), where prediction errors for 
peak clad temperature are very large. Since decay power falls with time, it is difficult to insure that such conditions can always be avoided.

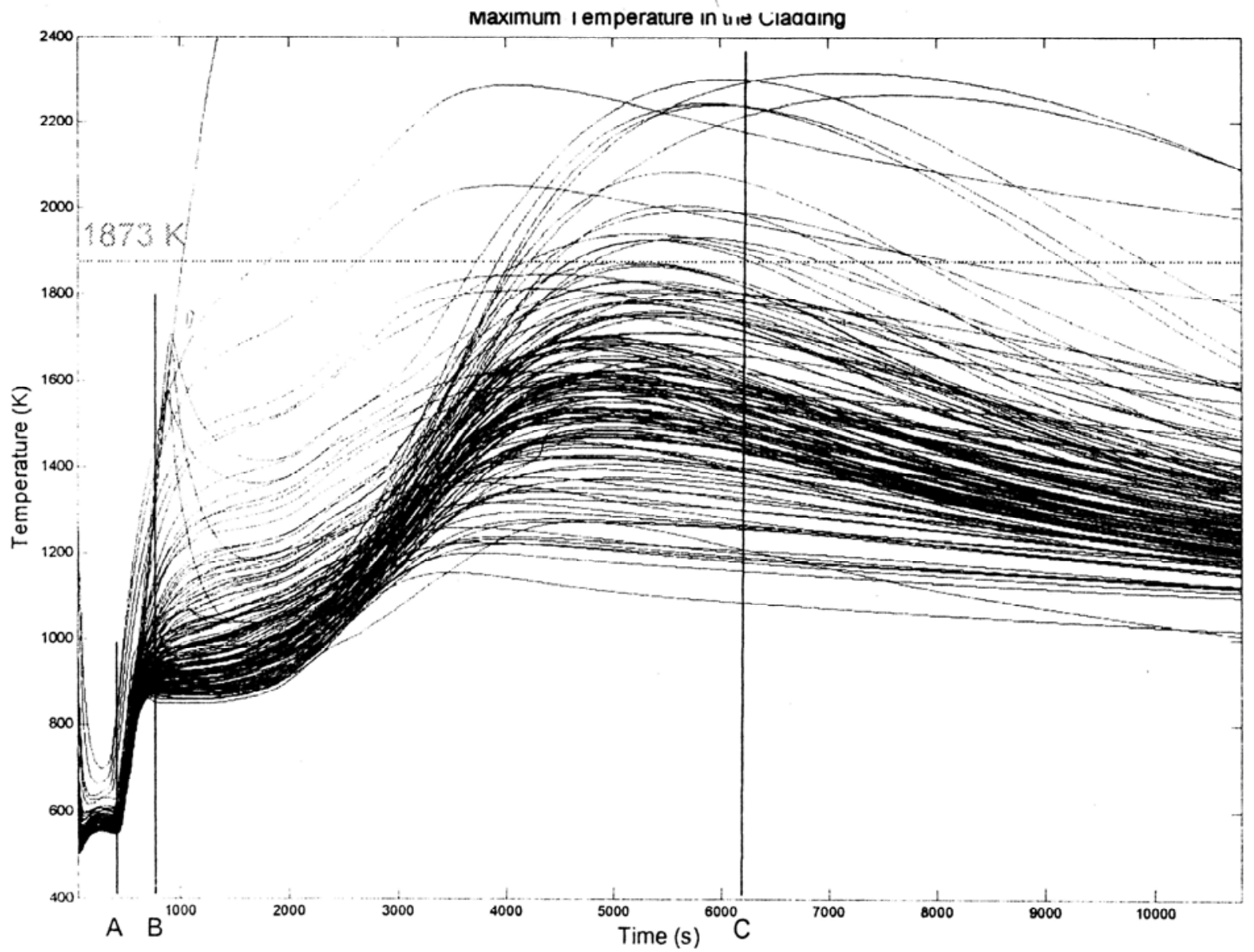

Figure 2.9: Post-LOCA Histories for Maximum Temperature in the Cladding

\subsubsection{RELAP5 Simulations of S-CO 2 Cooled GFR}

Extensive transient analyses to evaluate GFR response to various accidents have been performed for the MIT SCO 2 -cooled GFR. The computer code used for the transient analyses was RELAP5-3D (2-6), cited here as RELAP5 to signify the fact that only 1-D models were used, and the 3-D capability was not invoked. RELAP5 has $\mathrm{S}-\mathrm{CO}_{2}$ properties and compressor and turbine models, which were needed to simulate the $\mathrm{S}-\mathrm{CO}_{2}$ GFR system. Figure 2.10 shows a nodalization diagram of the RELAP5 model used to simulate the reactor, vessel and PCS loops; the SCS/ECS is omitted from this figure. The PCS loops are represented by a single $25 \%$ loop which is shown on the left side of the figure and a lumped $3 \times 25 \%$ loop which is shown on the right. Transients which are initiated in a single PCS, such as a LOCA or a Loss of Flow (LOF) in a single PCS, are assumed to occur in the single loop and the behavior of all of the remaining three loops is assumed to be identical. The containment volume is shown in the upper left corner of the 
figure (volume 900). The valves connecting the coaxial duct of the single PCS to this volume are modeled as fast-acting motor valves used to simulate breaks.

Detailed axial compressor performance curves were initially used in RELAP5 to represent main and recompressing compressors. Because of the relatively narrow band of operation of axial compressors, however, the need for transient simulations necessitated the use of homologous pump models to approximate the compressors. This allowed simulations to continue running though the compressors may have encountered a surge or choke condition. In later work, not only should protection be designed to prevent choking or surging, but radial compressors should be pursued, as they have a wider band of operation. All of the recuperators and precoolers are assumed to be vertical counterflow heat exchangers. This is a simplification since the actual flow in these Heatric ${ }^{\circledR}$ printed circuit heat exchangers (PCHE's) is more complicated. The cold side of the precooler is a water stream which is assumed to enter at $20^{\circ} \mathrm{C}$.

A nodalization diagram of the SCS/ECS and its attachments to the core downcomer and chimney are shown in Figure 2.11. Note that, as indicated in Figure 2.11, 100\% decay heat removal capacity is modeled in the SCS/ECS due to the assumption that half of the $200 \%$ capable SCS/ECS is not operational. Before steady state shutdown cooling or transient calculations were performed, the steady state performance of the RELAP5 model was compared to design values, showing excellent agreement. More details of RELAP5 models and transient analyses are documented in Pope et al. (2-7). This section will summarize the results of LOCA analyses, which were performed in addition to the above report. 




Figure 2.10: GFR System (w/o DHR system) RELAP5-3D Nodalization (2-7) 


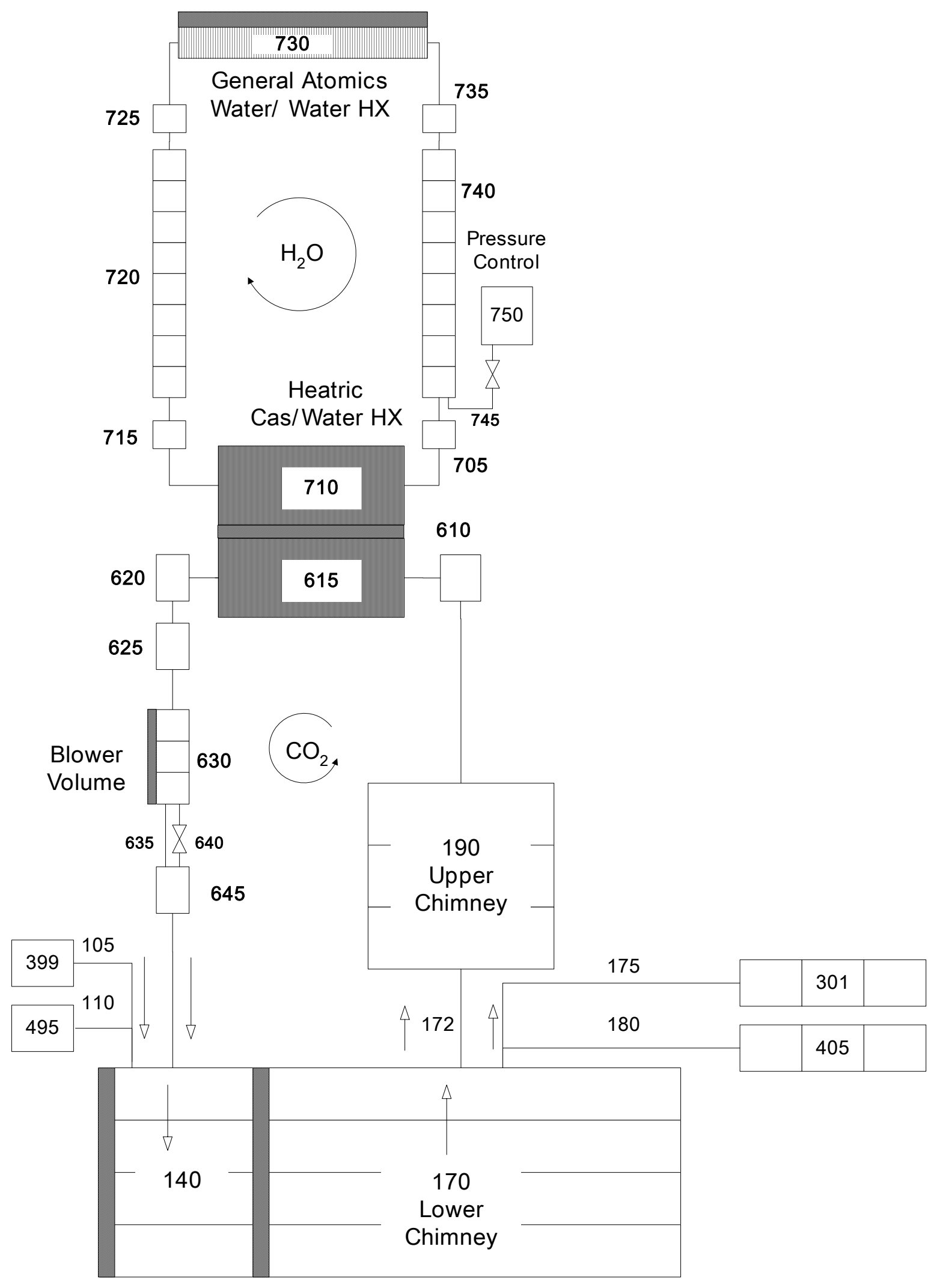

Figure 2.11: GFR-SCS/ECS System RELAP5-3D Nodalization (2-7) 


\section{Loss of Coolant Accident with Scram}

In order to prove that the redesigned SCS/ECS system is effective in protecting the GFR core against unacceptable fuel temperature increase under a LOCA, a $100 \mathrm{in}^{2}$ break in the cold side of the coaxial duct was simulated. The RELAP5 model on Figures 2.10 and 2.11 was used with some minor modifications to maximize the system safety performance. Minor changes were:

(1) The logic for engaging the ECS loop (here called ECS instead of SCS/ECS to signify that this is an emergency rather than a normal shutdown operation) to the core is changed from the differential pressure between the core and the ECS to a combined logic of the system pressure and the PCS turbocompressor shaft speed. This was necessary because the pressure difference between the core and the ECS is very small (a few Pascals) making it difficult to design reliable check valves to act on such a small pressure differential. The revised logic opens the fail-open airoperated valve connecting ECS loops and the core when the turbine velocity drops below $25 \mathrm{rad} / \mathrm{sec}$ and the system pressure decreases below the $\mathrm{CO}_{2}$ critical pressure of $7.38 \mathrm{MPa}$. The shaft speed signal is necessary to prevent the reversed flow through the ECS loop forming a core bypass during shaft coastdown. .

(2) The blower operation was connected to the ECS engaging logic. Thus, the blower is turned on with 600 seconds delay after the ECS valve opens.

(3) The orientation of the PCS was changed from vertical to horizontal to reflect development of the PCS design and to reduce the tendency of $\mathrm{CO}_{2}$ two-phase formation at the inlet of compressors during the LOCA transient.

Figure 2.12 plots the pressure history in the reactor vessel and in the containment, Figure 2.13 shows the mass flow rate through the core, the ECS loops and the PCS, and

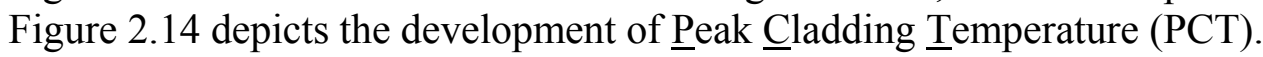




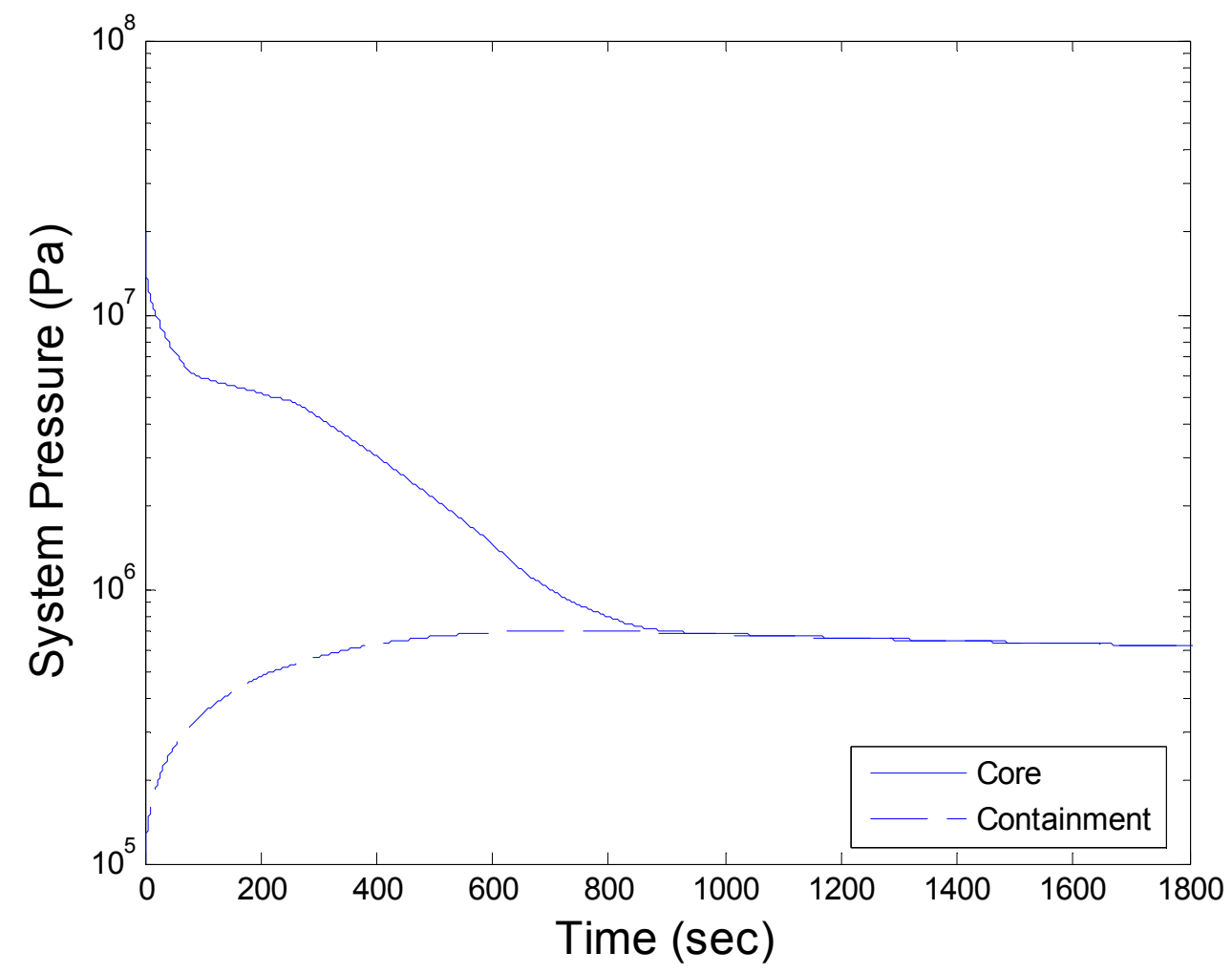

Figure 2.12: $\mathrm{S}-\mathrm{CO}_{2}$ GFR pressure during 100 in $^{2}$ break LOCA with scram.

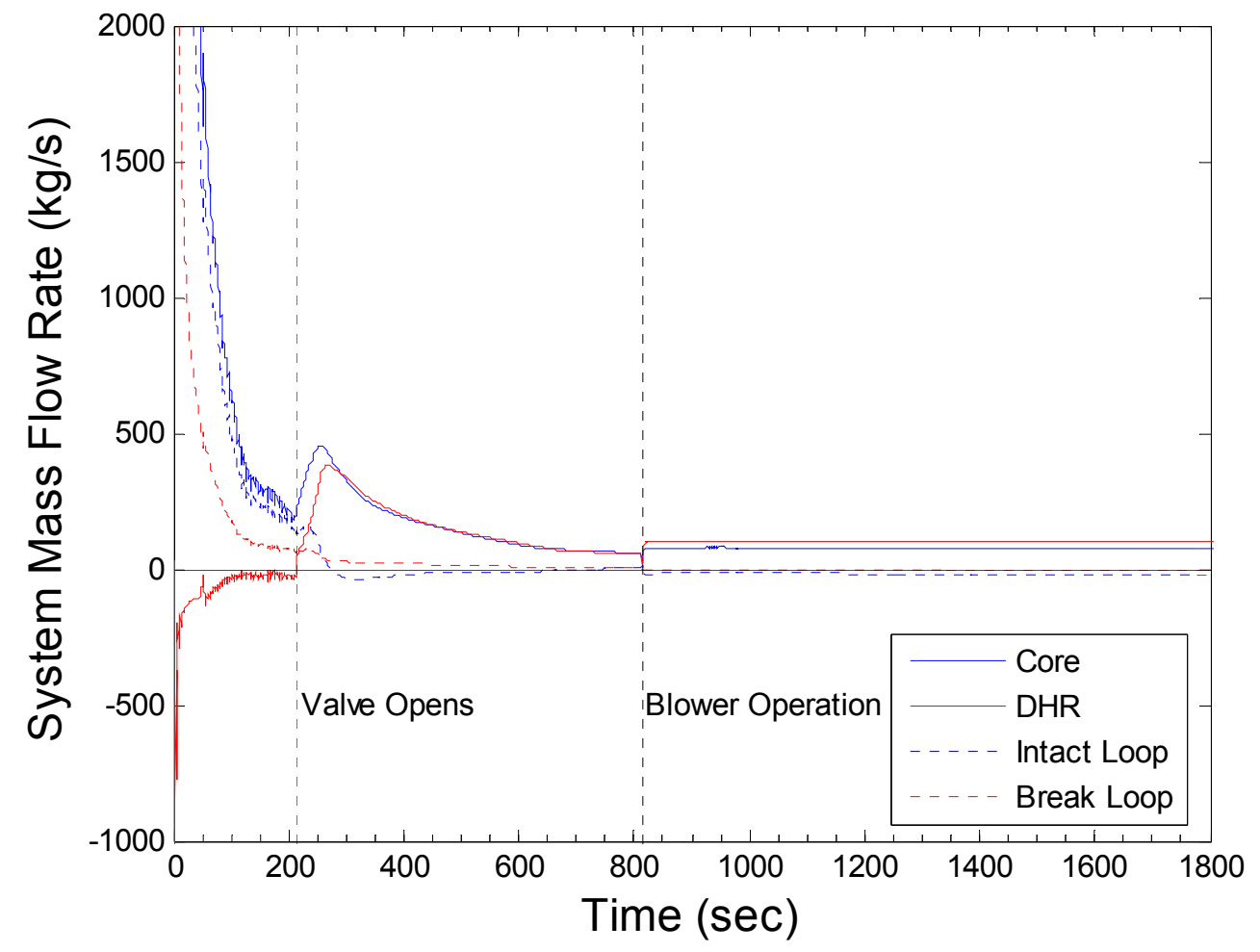

Figure 2.13: $\mathrm{S}-\mathrm{CO}_{2}$ GFR mass flow rate of individual systems during $100 \mathrm{in}^{2}$ break LOCA with scram. 


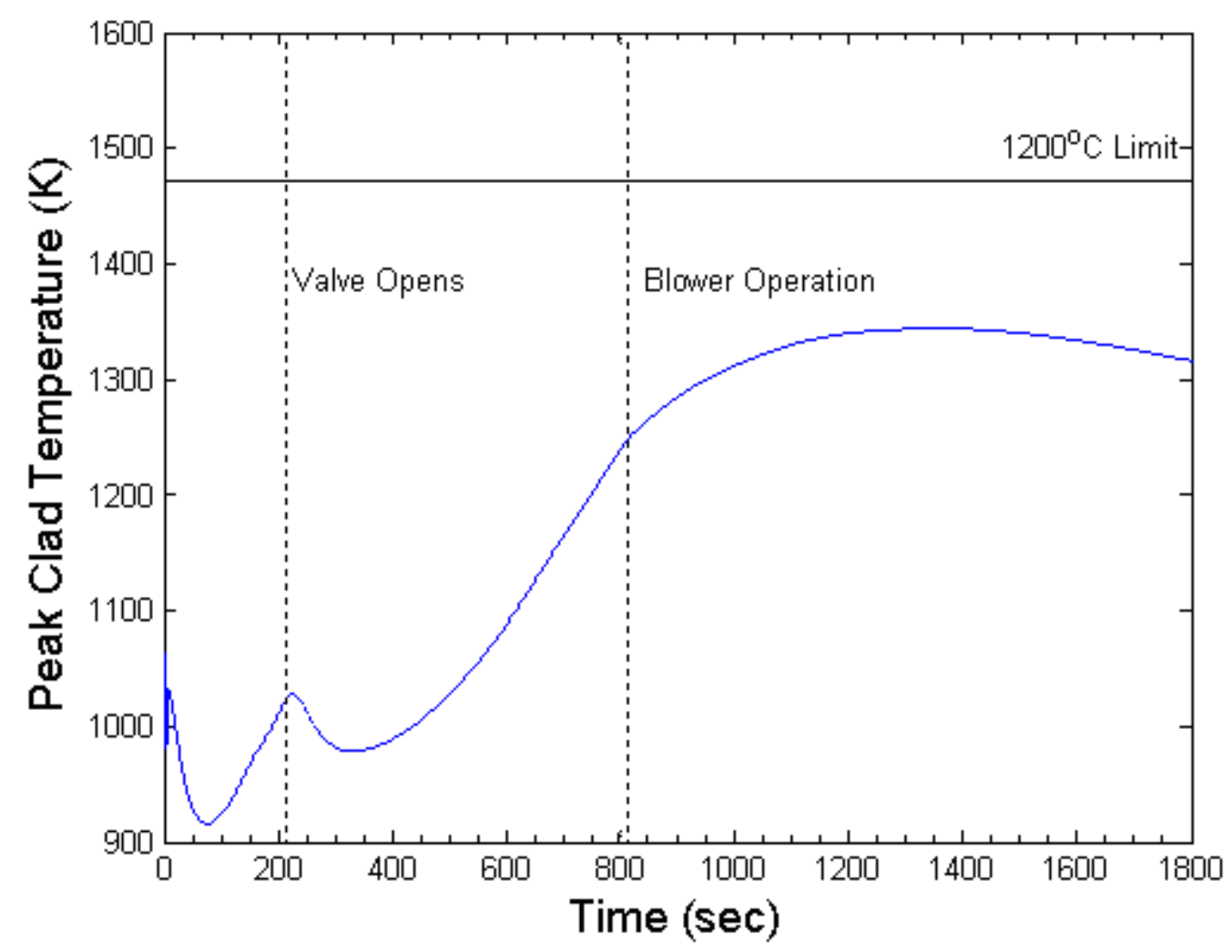

Figure 2.14: $\mathrm{S}-\mathrm{CO}_{2}$ GFR PCT during 100 in $^{2}$ break LOCA with scram.

The reactor is tripped on low system pressure, followed by generator trip, which results in gradual shaft coastdown. In the first 200 seconds, core cooling is primarily accomplished through compressor flow from shaft coast down, which is more than sufficient for the first 100 seconds, as observed from the decreasing trend of PCT on Figure 2.14. As shaft speed decreases, flow rate is reduced and PCT begins to rise until 200 seconds, when the ECS opens. ECS cooling capability at this time exceeds the decay heat due to high pressure in the reactor vessel at this time $(\sim 16 \mathrm{MPa})$, which results in the second PCT dip. However, as reactor vessel pressure is reduced, PCT begins to rise at 400 seconds until 1200 seconds when decay heat drops below ECS capacity. Note that after the blower is turned on at 800 seconds, PCT continues to rise, albeit at a lower rate. This is because blower rated flow was set to balance margin to the $1200^{\circ} \mathrm{C}$ PCT limit and battery power consumption to operate blowers. If smaller PCT is desired, this can be easily achieved by increasing blower power. It can be concluded that the active ECS adequately removes decay heat from the core and maintains the PCT below the $1473 \mathrm{~K}$ limit, which is the limit for the ODS MA956 cladding material. Also, we have learned that a slight modification of the control logic of the system can significantly improve the performance of the system.

\section{Loss of Coolant Accident without Scram}

During the design of the S-CO $\mathrm{CO}_{2}$ cooled GFR, substantial effort has been put into the development of a core design having such a combination of reactivity feedbacks that 
would yield inherent reactor shutdown in unprotected (without scram) transients. Handwerk et al. (2-4) used the simple Quasi-Static Method (QSM) by applying the reactivity equilibrium equation, which predicted that the core should be able to reach the final shutdown state without exceeding the fuel and cladding temperature limits. Although this method gives an indication about the final new steady state, it does not provide any information on whether the material limits are satisfied during the entire transient. Therefore, it is necessary to confirm the preliminary predictions through fullblown transient analysis. The purpose of this section is to validate the conclusions derived from the QSM for the case of GFR LOCA without scram.

Two core conditions were simulated for the LOCA without scram case: (1) Beginning of Life (BOL) and (2) End of Life (EOL), because reactivity coefficients differ significantly between these two states. Handwerk et al. (2-4) demonstrated through QSM that the BOL core should achieve passive shutdown, while this may not be possible at EOL because of a less favorable coolant density reactivity coefficient. To simulate LOCA without scram, the RELAP5 model was modified to incorporate the two key reactivity coefficients: (1) the Doppler feedback and (2) the coolant density feedback. There are other reactivity feedbacks, such as core radial expansion or fuel axial expansion, influencing the behavior of the core during the transient, but only the two feedbacks are explicitly modeled in RELAP5. This is because they are likely to have the largest impact on the transient behavior of the core and their change is the largest during the operation (from BOL to EOL) among other feedbacks (2-4).

The Doppler coefficient for a given temperature was taken from Handwerk et al., (2-4) per Eq. (2). The Doppler coefficient is a function of the temperature and it is the same for both BOL and EOL. However, since the effective delayed neutron fraction is different, the Doppler coefficient in $\$$ / (degree K of fuel average temperature) is different between BOL and EOL.

$$
\alpha_{\mathrm{D}} \approx-\frac{0.00448}{T^{0.8}}
$$

The coolant density coefficient was implemented in RELAP5 as a linear interpolation between the steady state operation and fully depressurized condition. Steady state average fluid density in the core is $131.6 \mathrm{~kg} / \mathrm{m}^{3}$ while fully depressurized average fluid density is about $5.3 \mathrm{~kg} / \mathrm{m}^{3}$. The BOL core has a coolant void reactivity (CVR) of $-1.08 \$ /\left(\mathrm{kg} / \mathrm{m}^{3}\right.$ average fluid density) when it is fully depressurized, while the EOL core has a CVR of $0.36 \$ /\left(\mathrm{kg} / \mathrm{m}^{3}\right.$ average fluid density).

Figure 2.15 shows the reactor power history for both BOL and EOL following LOCA without scram. It should be noted that RELAP5 terminated the EOL LOCA calculation around $140 \mathrm{sec}$ due to overheating of the clad material. It can be observed that the reactor power at EOL decreases slower than for the BOL core due to its less negative coolant density coefficient. Figure 2.16 plots the PCT for the BOL and EOL cores versus time following the LOCA without scram. The PCT for the BOL core remains well below the safety limit during the LOCA transient, while the PCT for the EOL core exceeds the limit at 80 seconds. This is because power reduction from reactivity feedbacks for the EOL case is not fast enough to match the decay heat removal capacity of the ECS. 
These calculations confirm that the following conclusions derived from the simple QSM are valid for the LOCA without scram case: the BOL core can be protected from overheating while the EOL core has difficulties in the beyond design basis scenario. If there is a desire to accomplish inherent shutdown under all conditions, design changes to the core would have to be made to make EOL coolant void worth more negative, or implement other measures, such as flow levitated absorbers. It is also important to note that the GFR is significantly different from sodium cooled reactors, where inherent shutdown can be achieved even if the coolant temperature coefficient is slightly positive (2-8), because it is compensated by other negative reactivity feedbacks. For example, in sodium cooled fast reactors (where LOCA is not a postulated accident), radial assembly bowing is heavily relied upon for passive shutdown in unprotected scenarios. This feedback is driven, in large part, by a gradient in coolant temperature across assemblies on the periphery and the resulting uneven heating on the hex-cans. In a GFR, which appears to have a more constrained fuel in the TID configuration, the low heat transfer coefficient of $\mathrm{CO}_{2}$ under LOCA is not likely to cause significant radial assembly bowing. Furthermore, in a GFR, depressurization may occur quickly before this and other negative feedbacks, such as lower plate expansion, can respond to compensate. Therefore, the CVR for the GFR must be negative if inherent shutdown in unprotected accidents is the designer's goal. Moreover, because of the low heat transfer capability of gases under natural circulation, it is difficult to design the passive decay heat removal system with large margins, hence the CVR should be sufficiently large in addition to being negative.

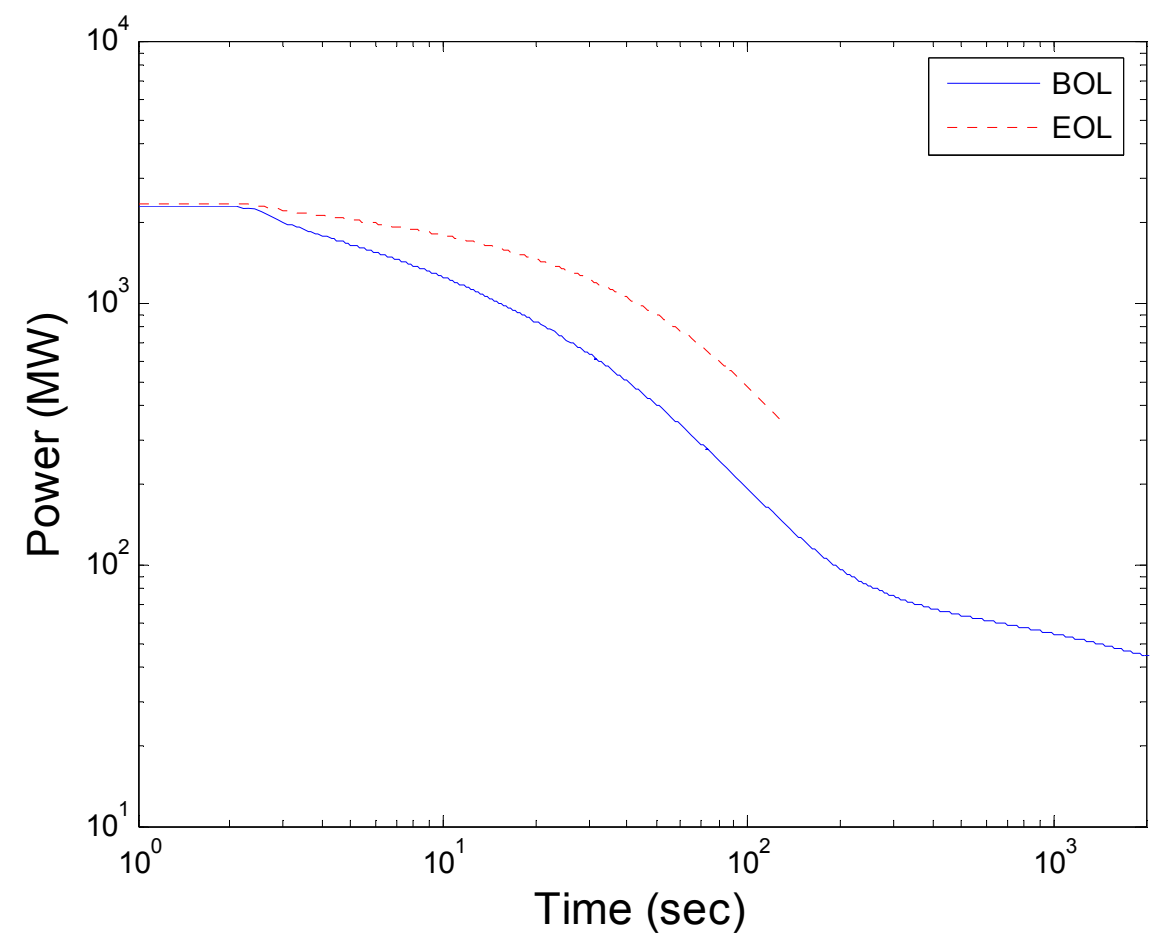

Figure 2.15: $\mathrm{S}-\mathrm{CO}_{2}$ GFR reactor power during $100 \mathrm{in}^{2}$ break LOCA without SCRAM at BOL \& EOL. 


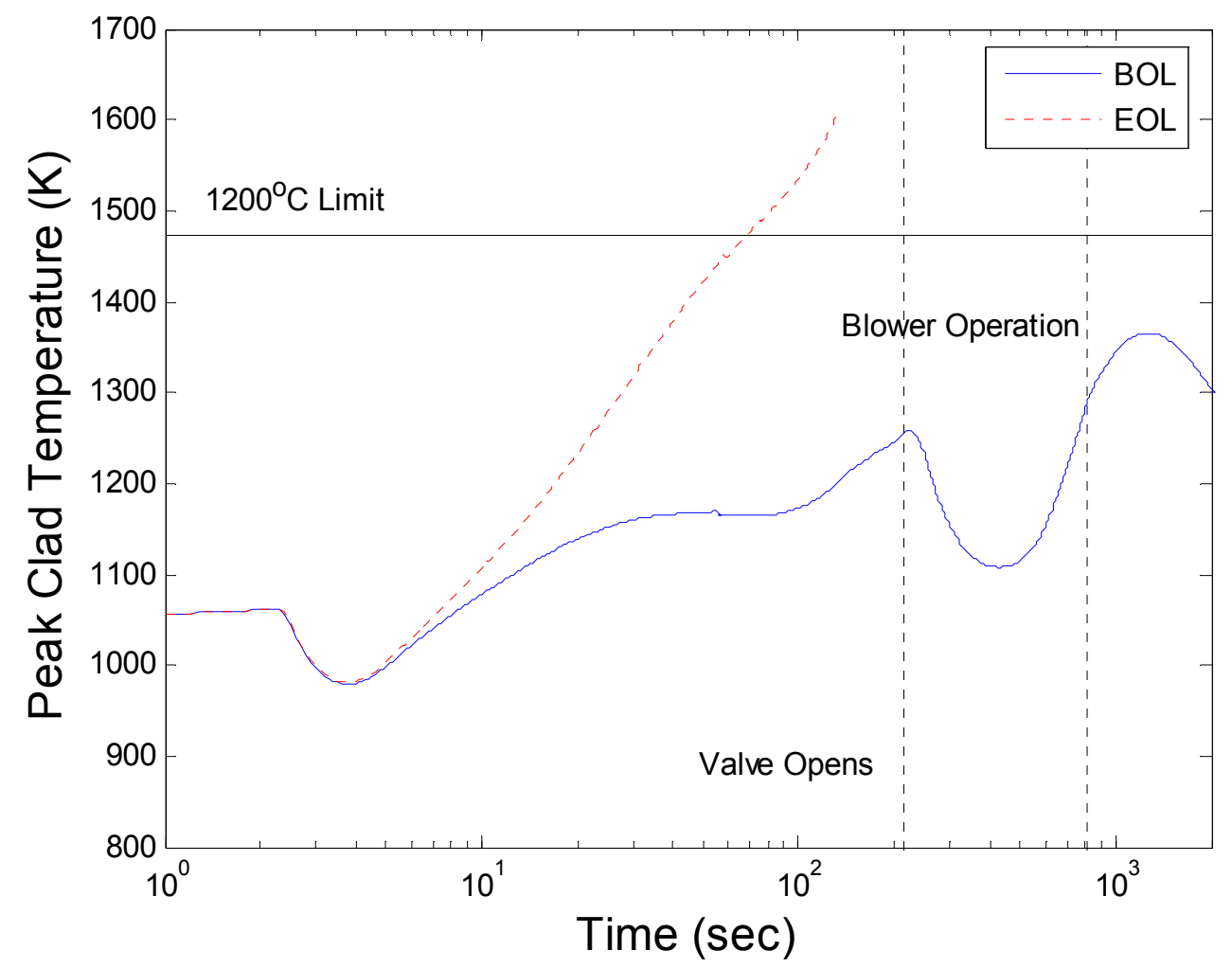

Figure 2.16: $\mathrm{S}-\mathrm{CO}_{2}$ GFR reactor peak cladding temperature during 100 in $^{2}$ break LOCA without SCRAM at BOL \& EOL.

\subsubsection{Heat Transfer Deterioration in Low-Flow Post-LOCA Regimes}

Early investigations at MIT (2-16) suggested that the approach of passive decay heat removal via natural circulation loops with gas upflow in the core can lead to Reynolds and Grasshoff numbers that support mixed convection flow with reduced heat transfer coefficients. The deterioration of the turbulent heat transfer occurs due to two effects: (1) buoyancy effect and (2) acceleration effect. Both effects reduce the turbulence generation near a heated wall when the heating rate is high (2-11) based on governing non-dimensional numbers. This is especially an issue for gas flows at elevated pressures (but below the critical point), since most correlations to date were developed for flows at atmospheric pressure or at supercritical conditions. Because these heat transfer regimes carry large uncertainties, a parallel program funded by INL Laboratory Directed Research and Development (LDRD) was carried out during this NERI project to obtain experimental data to reduce uncertainties and develop more robust correlations that can cover these regimes. The results of this program, fully documented in Refs $(2-11,2-12$, $2-13,2-14)$, are summarized in this section, as they have significant impact on the postLOCA cooling of GFRs and contributed to the decision to select active decay heat removal systems over passive ones as the first line of defense. 
Figure 2.17 shows the schematic diagram of the experimental facility. The loop is a relatively tall facility with a height of $7 \mathrm{~m}$, has a heated section length of $2 \mathrm{~m}$, and can be pressurized up to $1 \mathrm{MPa}$. The diameter of the heated channel is $15.7 \mathrm{~mm}$, which corresponds to one of our earlier GFR designs and allows an investigation of both buoyancy and acceleration driven deteriorated heat transfer. The details of the experimental facility are explained in Refs $(2-11,2-12)$ and will not be repeated here.

\subsubsection{Experimental Data}

The major focus of the experiment was the conditions controlling the deteriorated turbulent heat transfer (DTHT) regime in gas up-flow. Data were collected for three gases - nitrogen, helium and carbon dioxide. Each gas covered a different part of the DTHT regime. The nitrogen data covered the acceleration and buoyancy driven DTHT, the helium data covered the laminar mixed convection, acceleration driven DTHT and laminar to turbulent transition regimes and the carbon dioxide data covered the buoyancy driven DTHT. In addition, a new "returbulizing" buoyancy driven DTHT regime in the heated up-flow gas heat transfer was identified. It is defined as a change of the gas heat transfer regime from the buoyancy DTHT to the forced turbulent regime when the buoyancy force is decreased at the downstream of the channel. Both the acceleration driven DTHT and the buoyancy driven DTHT showed a reduction of heat transfer coefficient of up to $70 \%$ compared to the normal turbulent heat transfer, as can be observed on Figure 2.18, which summarizes the data. 


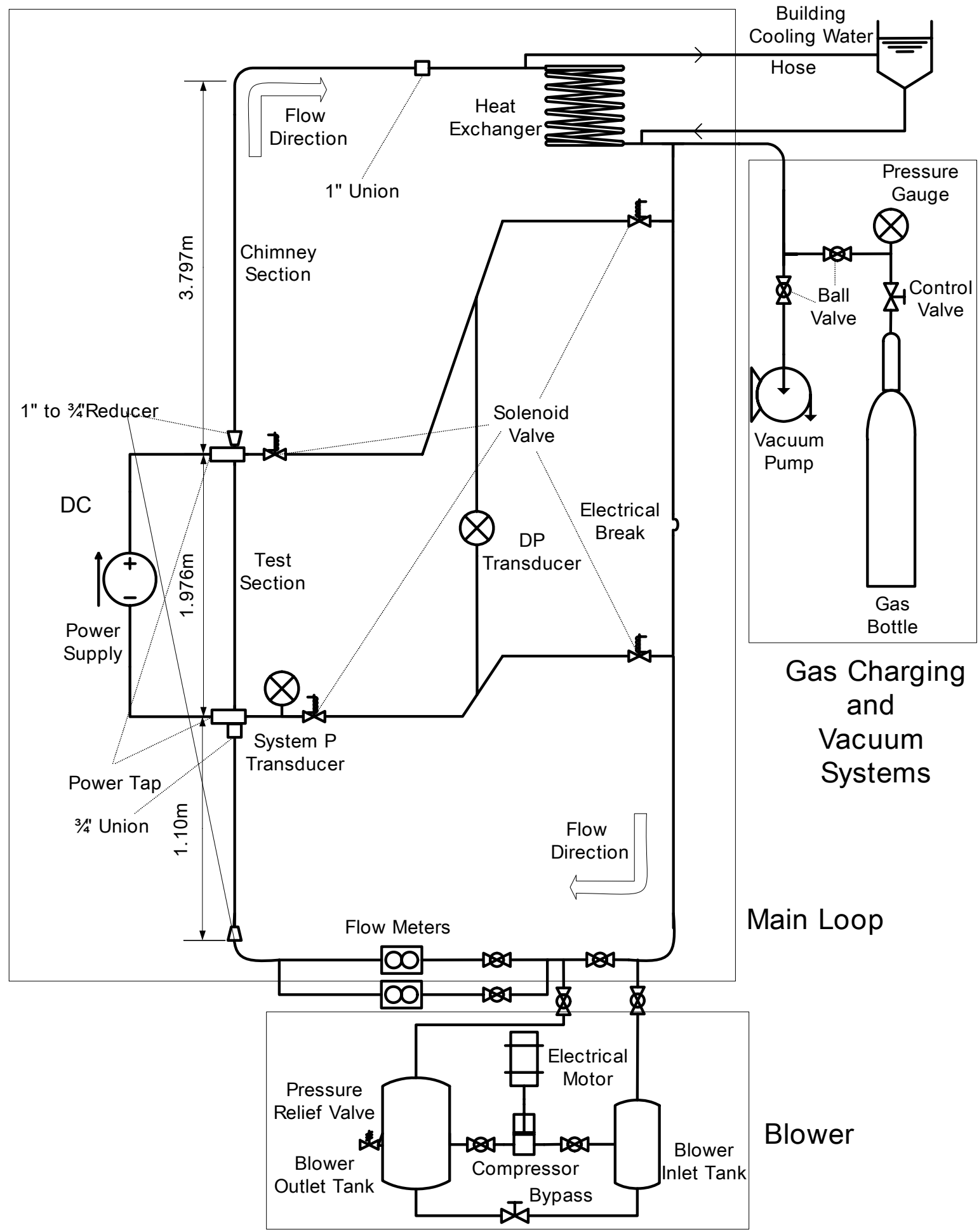

Figure 2.17: Schematic Diagram of Experimental Loop 


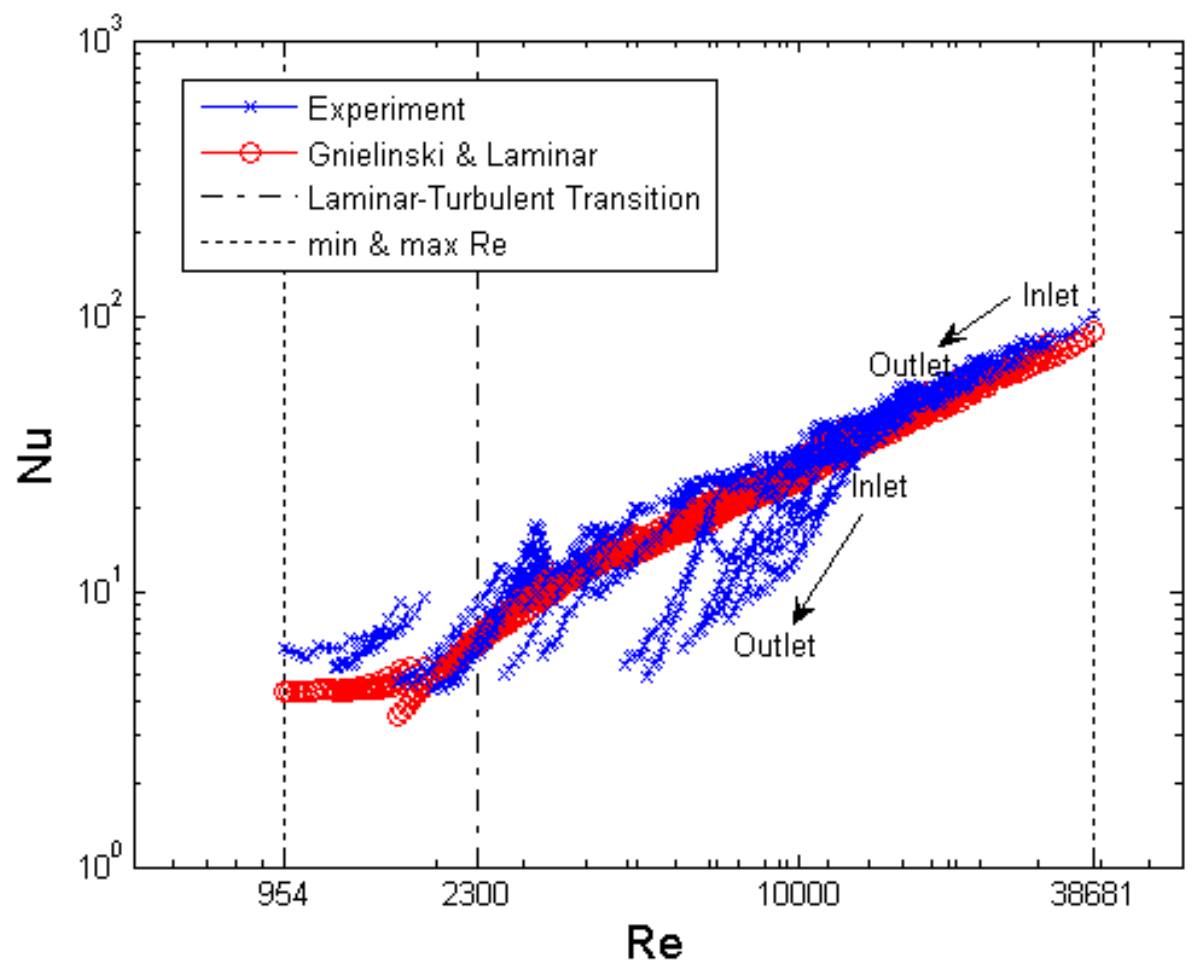

Figure 2.18: Summary of all heat transfer data in Nu-Re plot

The Gnielinski correlation (2-10) in Figure 2.18 is given by the relation:

$\mathrm{Nu}_{\text {Gnielinski }}=\frac{(f / 8)(\operatorname{Re}-1000) \operatorname{Pr}}{1+12.7 \sqrt{f / 8}\left(\operatorname{Pr}^{2 / 3}-1\right)}\left(\frac{T_{w}}{T_{b}}\right)^{-0.45}\left(1+\left(\frac{x}{D}\right)^{-\frac{2}{3}}\right)$,

where $\quad f=\left(1.82 \log _{10} \operatorname{Re}-1.64\right)^{-2}$.

\subsubsection{New Heat Transfer Correlation}

The comparison of experimental data from Figure 2.18 against available correlations has shown that the currently available correlations have great difficulties to predict data with sufficient accuracy (2-15). Therefore, three new sets of correlations, each covering the mixed convection laminar, normal turbulent and deteriorated turbulent heat transfer (DTHT) regimes for heated gas up-flow, have been developed to agree better with the data in each regime. The simplest form (Type-3) of the new correlation, which utilizes a new non-dimensional number that combines the acceleration and the buoyancy effects, is listed below: 


$$
\begin{aligned}
& \text { If } K_{v \text { in }}<2.5 \times 10^{-6}, B o^{*}<2.0 \times 10^{-6} \text { and } \operatorname{Re}_{\text {in }}>2300 \text { (Turbulent) } \\
& \mathrm{Nu}_{\mathrm{TYPE} 3}=\frac{(f / 8)(\operatorname{Re}-1000) \mathrm{Pr}}{1+12.7 \sqrt{f / 8}\left(\operatorname{Pr}^{2 / 3}-1\right)}\left(\frac{T_{w}}{T_{b}}\right)^{-0.5}\left(1+\frac{x^{-\frac{2}{3}}}{D}\right)
\end{aligned}
$$

$$
\begin{aligned}
& \text { If } K_{v \text { in }} \geq 2.5 \times 10^{-6} \text { or } \mathrm{Bo}^{*}{ }_{i n} \geq 2.0 \times 10^{-6} \text { and } \mathrm{Re}_{\text {in }}>2300 \text { (DTHT) } \\
& \mathrm{Nu}_{\text {TYPE } 3 \text {-temp }}=\frac{(f / 8)\left(\operatorname{Re}-0.011\left(\frac{q^{+}}{\operatorname{Re}^{0.44}}\right)^{-1.16}\right) \operatorname{Pr}}{1+12.7 \sqrt{f / 8}\left(\operatorname{Pr}^{2 / 3}-1\right)}\left(\frac{T_{w}}{T_{b}}\right)^{-0.5}\left(1+\frac{x^{-\frac{2}{3}}}{D}\right)
\end{aligned}
$$

$$
\mathrm{Nu}_{\text {TYPE3 }}=\max \left(\mathrm{Nu}_{\text {TYPE3-temp }}, \mathrm{Nu}_{\text {Laminar }}\right)
$$

In the above relations, Acceleration parameter $\mathrm{K}_{\mathrm{v} \text { in }}$ and Buoyancy number $\mathrm{Bo}^{*}$ in are based on channel inlet and are given by

$$
\begin{aligned}
& K_{v}=\frac{4 q^{+}}{\operatorname{Re}} \\
& B o^{*}=\frac{\mathrm{Gr}_{q}}{\operatorname{Re}^{3.425} \operatorname{Pr}^{0.8}}
\end{aligned}
$$

where

$q^{+}$is nondimensional heat flux $=q_{w}^{\prime \prime} / G H_{b} \approx q_{w}^{\prime \prime} / G c_{p} T_{b} \approx \beta q_{w}^{\prime \prime} / G c_{p}$

and

$\mathrm{Gr}_{q}$ is Grashof number based on heat flux $=g \beta q_{w}^{\prime \prime} D^{4} / k v^{2}$.

\subsubsection{Additional Data in Natural Circulation Mode}

After experimental data were obtained and new heat transfer correlations were developed under the LDRD program, the heat transfer loop was used under this NERI program to expand data under full natural circulation conditions and to benchmark 
RELAP5-3D against loop data. More details on these activities are given in Lee et al. (213). To reach steady state natural circulation faster, the flow was first initiated with the compressor, and after the walls of the test and chimney sections heated up enough to maintain the natural circulation, the entire blower section was isolated from the loop. To minimize the heat losses in the long chimney section, the chimney section is equipped with insulation and temperature controlled guard heaters that maintain the bulk temperature along the chimney section equal to that of the test section outlet bulk temperature to the closest extent possible.

Seven additional runs were made with nitrogen and carbon dioxide at different operating conditions. Table 2.3 provides the operating conditions for each run.

Table 2.3: Experimental Conditions for Natural Circulation Loop

\begin{tabular}{|c|c|c|c|c|c|c|c|c|c|}
\hline Run $\#$ & Gas & $\begin{array}{r}\text { Pressure } \\
(\mathrm{MPa})\end{array}$ & $\begin{array}{c}\text { Mass } \\
\text { flow rate } \\
(\mathrm{kg} / \mathrm{sec})\end{array}$ & $\begin{array}{c}\text { Inlet } \\
\text { Temperature } \\
(\mathrm{K})\end{array}$ & $\begin{array}{c}\text { Inlet } \\
\mathrm{Re}\end{array}$ & $\begin{array}{c}\text { Inlet } \\
\mathrm{q}^{+}\end{array}$ & Inlet $\mathrm{Bo}^{*}$ & Inlet $\mathrm{K}_{\mathrm{V}}$ & $\mathrm{Tw} / \mathrm{Tb}$ \\
\hline 1 & N2 & 0.496 & $\underset{3}{1.043 \times 10}$ & 299.6 & 4,591 & 0.0037 & $1.57 \times 10^{-5}$ & $3.24 \times 10^{-6}$ & $1.66 \sim 1.17$ \\
\hline 2 & N2 & 0.695 & $\underset{3}{1.495 \times 10}$ & 297.9 & 6,608 & 0.0036 & $1.25 \times 10^{-5}$ & $2.22 \times 10^{-6}$ & $1.78 \sim 1.20$ \\
\hline 3 & N2 & 0.562 & $\underset{3}{1.666 \times 10}$ & 296.5 & 7,452 & 0.0024 & $4.19 \times 10^{-6}$ & $1.31 \times 10^{-6}$ & $1.63 \sim 1.14$ \\
\hline 4 & $\mathrm{~N} 2$ & 0.401 & $\begin{array}{c}0.978 \times 10 \\
3\end{array}$ & 295.4 & 4,343 & 0.0043 & $1.36 \times 10^{-5}$ & $3.92 \times 10^{-6}$ & $1.56 \sim 1.09$ \\
\hline 5 & $\mathrm{CO} 2$ & 0.271 & $\underset{3}{1.155 \times 10}$ & 294.7 & 6,106 & 0.0023 & $1.05 \times 10^{-5}$ & $1.48 \times 10^{-6}$ & $1.63 \sim 1.15$ \\
\hline 6 & $\mathrm{CO} 2$ & 0.374 & $\underset{3}{1.892 \times 10}$ & 294.1 & 10,073 & 0.0019 & $5.18 \times 10^{-6}$ & $7.49 \times 10^{-7}$ & $1.79 \sim 1.21$ \\
\hline 7 & $\mathrm{CO} 2$ & 0.534 & $\underset{3}{3.049 \times 10}$ & 293.7 & 16,336 & 60.0015 & $2.73 \times 10^{-6}$ & $3.68 \times 10^{-7}$ & $1.91 \sim 1.23$ \\
\hline
\end{tabular}

Figure 2.19 shows the operating conditions for the inlet buoyancy parameter versus the inlet acceleration parameter plane along with the threshold value for each parameter. By adopting newly proposed thresholds for the DTHT regimes (2-11) (the thresholds are also shown in the new correlation above), all seven cases were operating in the deteriorated turbulent heat transfer (DTHT) regime. It can be observed that both nitrogen and carbon dioxide experienced significant turbulent heat transfer deterioration even though their inlet Reynolds numbers are well above the critical Reynolds number of 2,300 (Figs. 2.20, 2.21). A significant deterioration of the turbulent heat transfer was observed towards the outlet of the channel, and three sets of nitrogen data were obtained where both the inlet buoyancy and the inlet acceleration parameters exceeded threshold values (Mixed DTHT in Figure 2.19). 


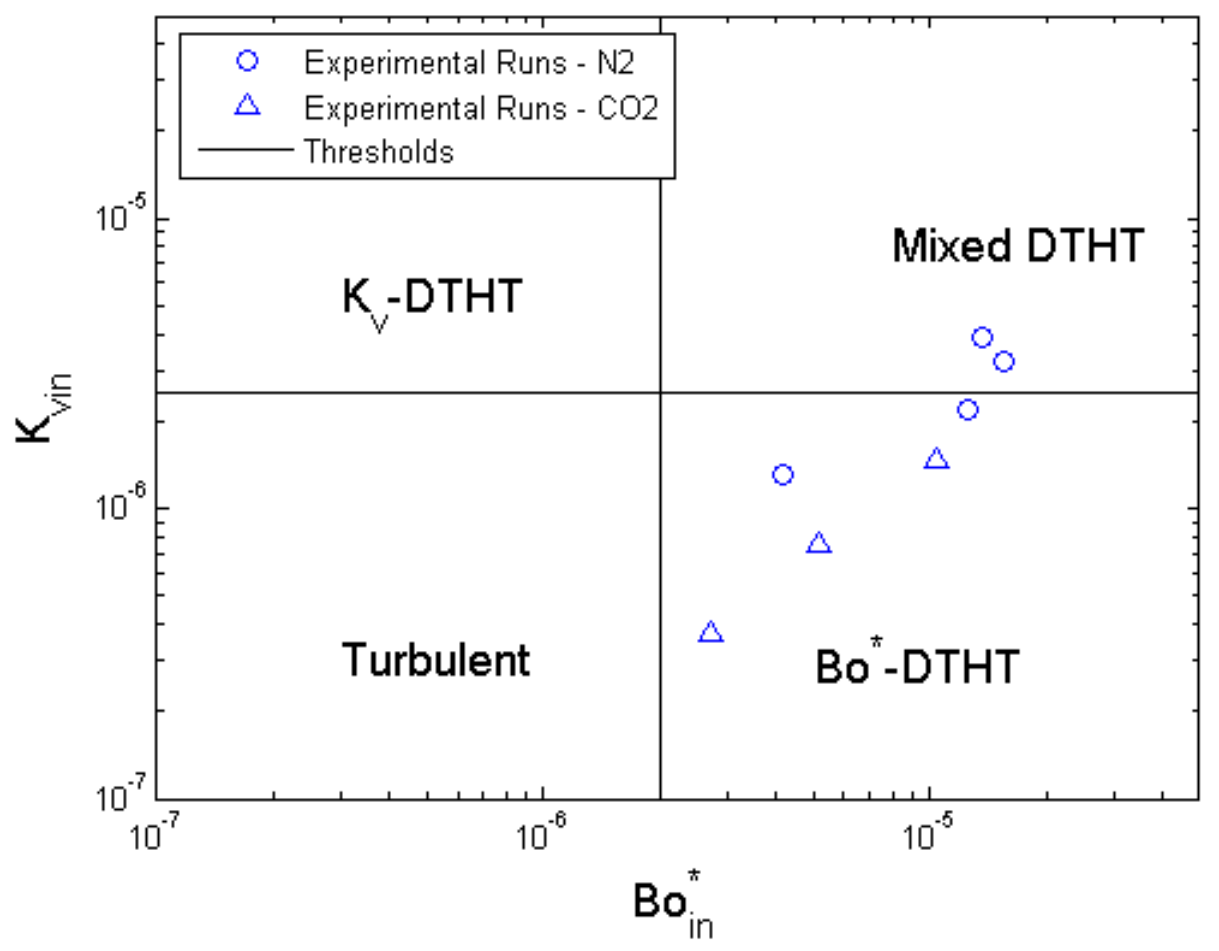

Figure 2.19: Operating Conditions on Inlet $\mathrm{K}_{\mathrm{v}}$ vs. Inlet $\mathrm{Bo}^{*}$ Plane

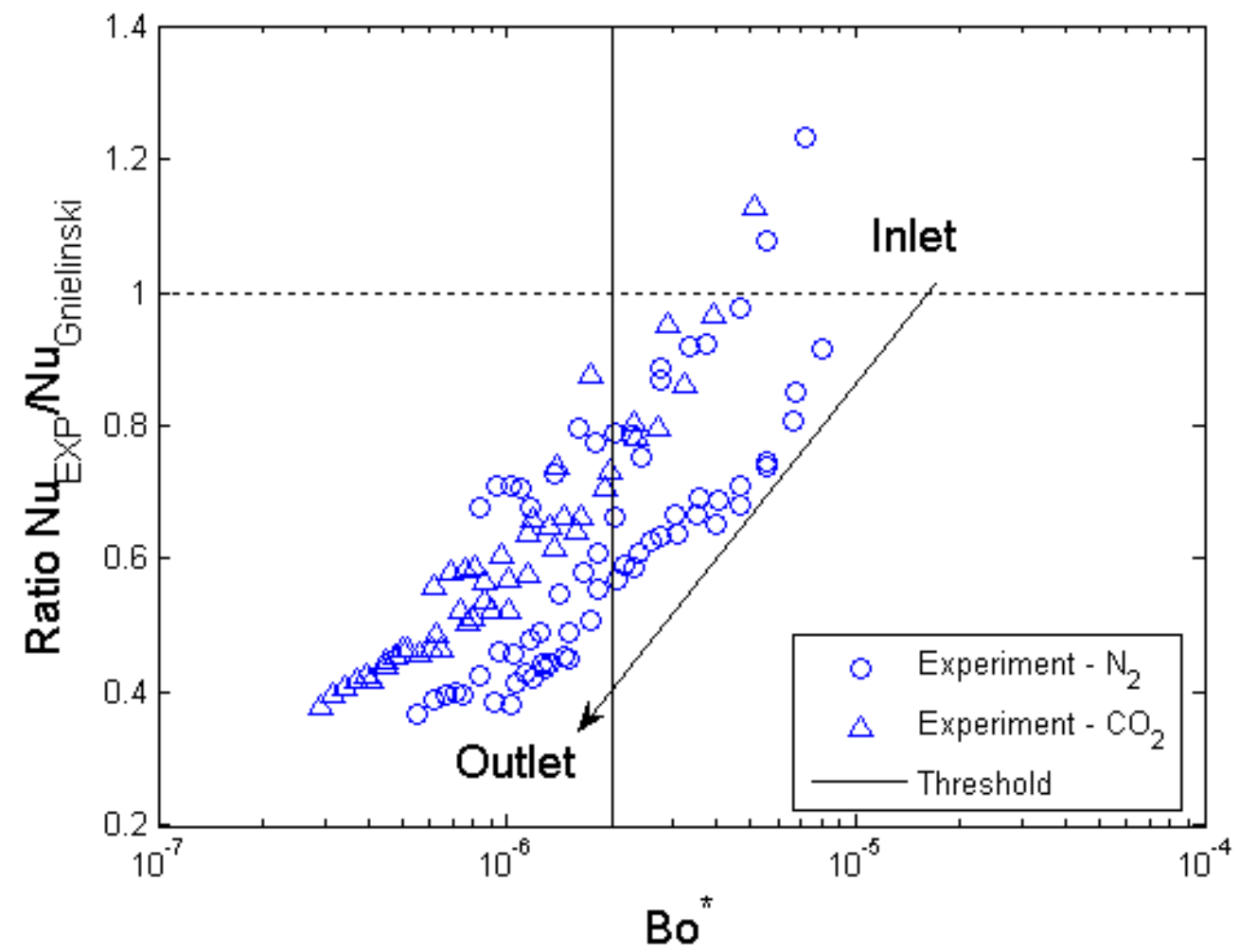

Figure 2.20: Effect of Buoyancy on Turbulent Heat Transfer 


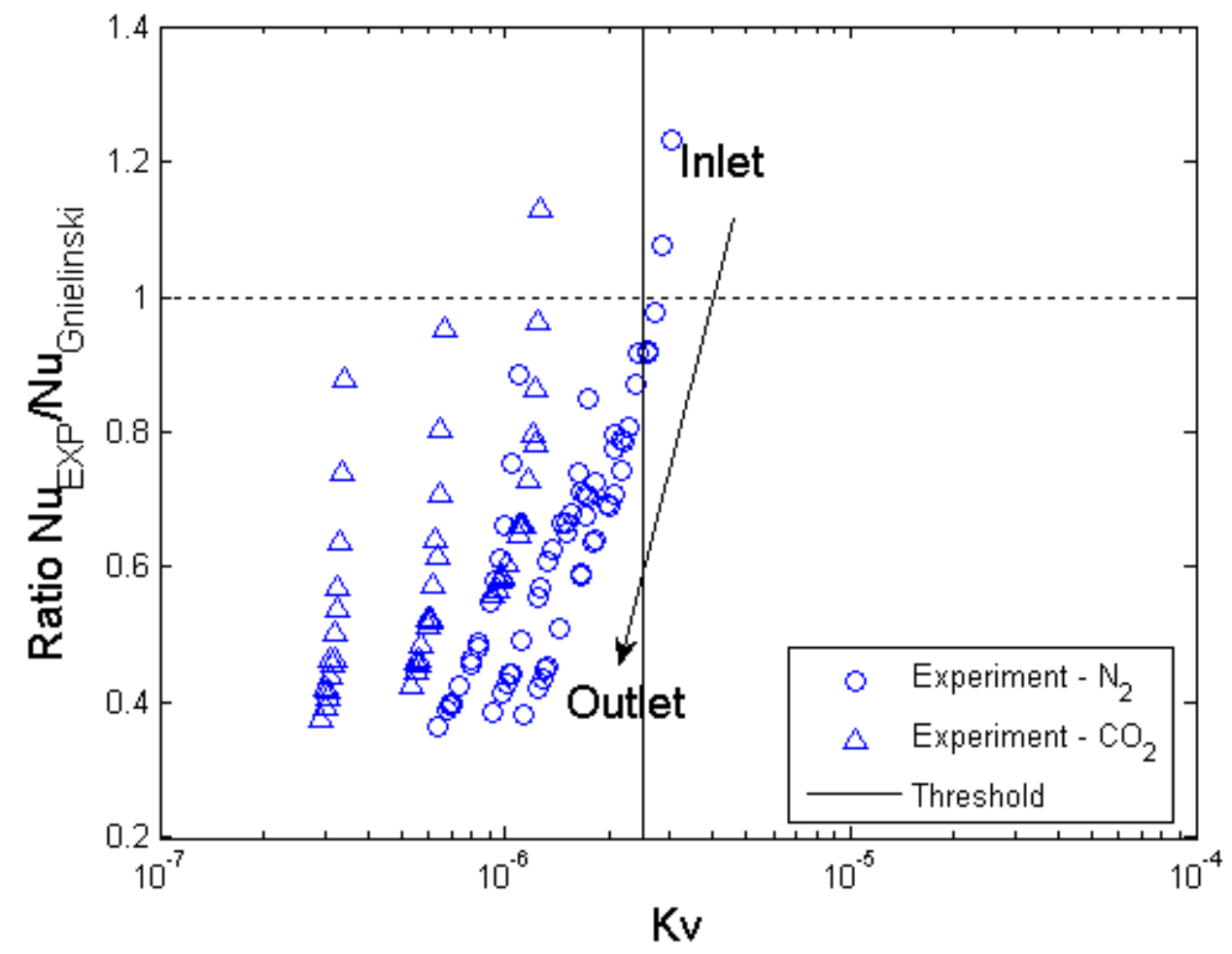

Figure 2.21: Effect of Acceleration on Turbulent Heat Transfer

\subsubsection{RELAP5-3D Benchmarking}

Figure 2.22 shows the loop nodalization for the RELAP5-3D model. Since the final steady state natural circulation flow is numerically simulated (not the startup), the blower section is omitted from the modeling. Two heat transfer correlations are available in RELAP5-3D - (1) Dittus-Boelter ("DB" in all legends) and (2) Gnielinski ("GN" in all legends) - and both correlations were tested. However, it should be noted that the DittusBoelter correlation is implemented without considering the thermally developing length effect and the radial property variation effect in RELAP5-3D. On the other hand, the Gnielinski correlation is implemented with the property modification factor and the thermally developing length, as shown in Eq. (2-1). It is noted that RELAP5-3D has a capability of calculating the strong buoyancy effect on the turbulent heat transfer for supercritical fluids. However, RELAP5-3D does not apply the model to fluids that are operating below the critical pressure. Thus, only the forced turbulent heat transfer correlations are compared to our experimental data.

Table 2.4 shows the differences between RELAP5-3D calculated and measured values of the natural circulation mass flow rate and the test section inlet bulk temperature and Figure 2.23 plots the comparison of bulk and wall temperatures along the heated channel for Run \#5. 


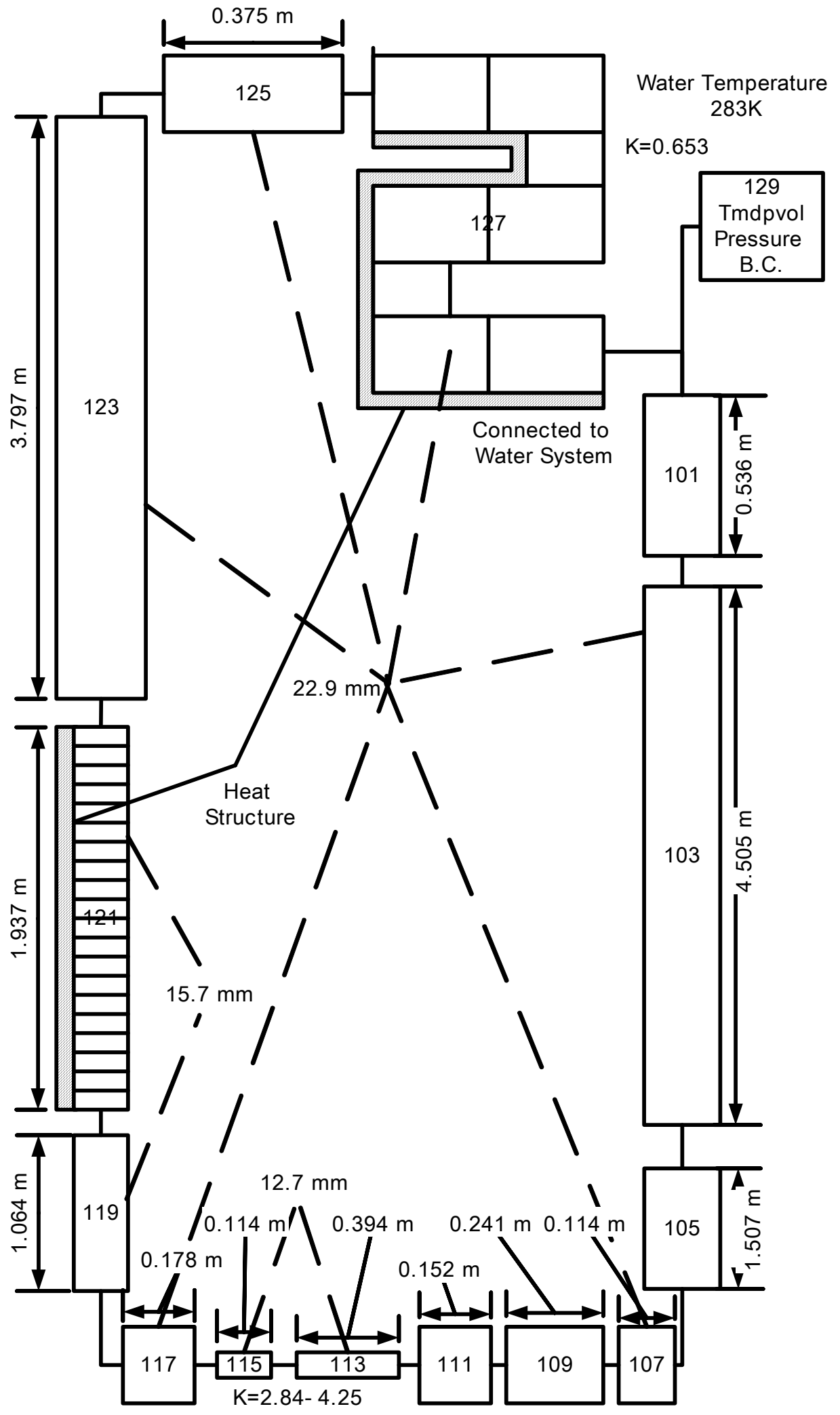

Figure 2.22: Nodalization of the Experimental Facility for RELAP5-MOD3 Input 
Table 2.4: Summary of RELAP5-3D Results

\begin{tabular}{|c||c|c|c|c|}
\hline \multirow{2}{*}{ Run \# } & \multirow{2}{*}{$\begin{array}{c}\text { Mass Flow Rate } \\
\text { Error (\%) }\end{array}$} & Inlet $\Delta \mathrm{T}_{\mathrm{b}}(\mathrm{K})$ & \multicolumn{2}{|c|}{$\operatorname{Max} \Delta \mathrm{T}_{\mathrm{w}}(\mathrm{K})$} \\
\cline { 4 - 5 } & 23.2 & -6.9 & $\mathrm{DB}$ & $\mathrm{GN}$ \\
\hline 1 & 9.4 & -3.4 & 292.2 & 290.4 \\
\hline 2 & -9.5 & -3.0 & 179.5 & 279.8 \\
\hline 3 & 11.2 & 1.0 & 163.6 & 136.8 \\
\hline 4 & 6.6 & 2.6 & 166.7 & 146.7 \\
\hline \hline 5 & -7.9 & 4.0 & 187.2 & 170.9 \\
\hline 6 & -14.5 & 2.7 & 216.6 & 202.4 \\
\hline 7 & & & & \\
\hline
\end{tabular}

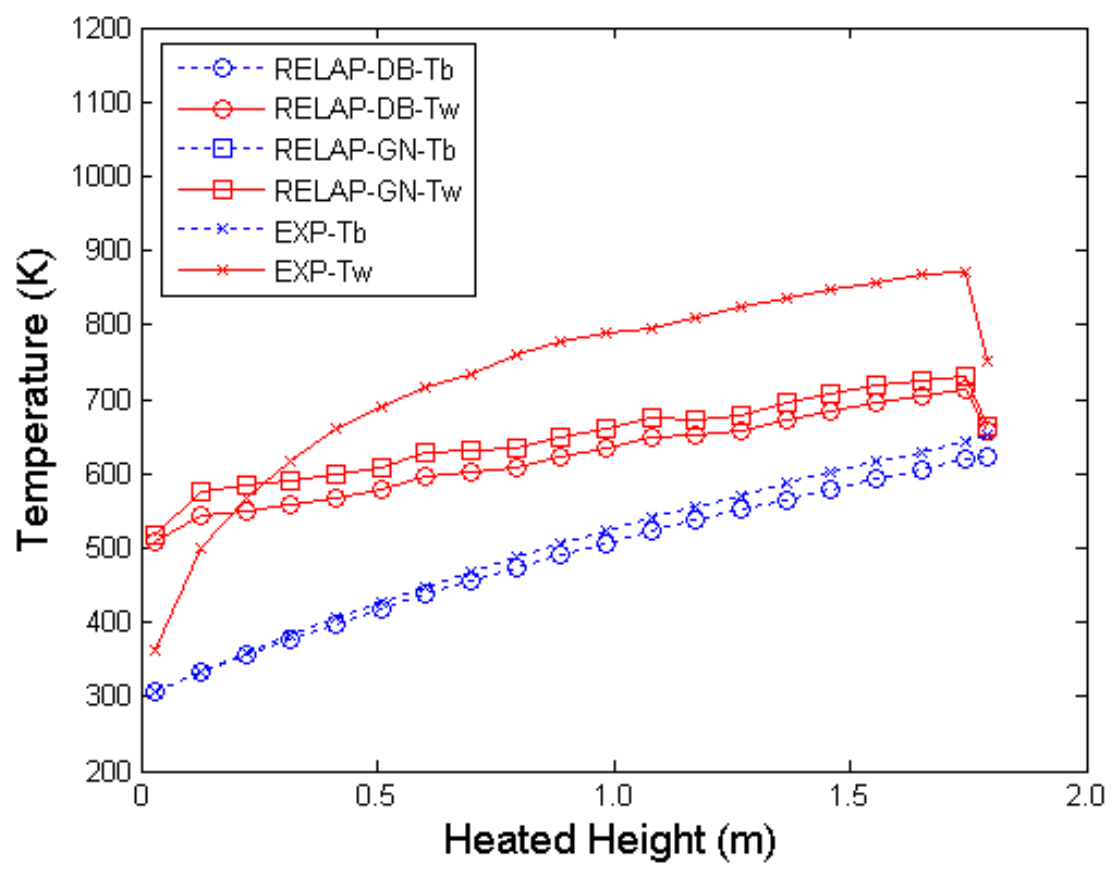

Figure 2.23: RUN \#5 Experimental Data vs. RELAP5

The maximum wall temperature difference is also shown for two different heat transfer correlations, the Dittus-Boelter (DB) and the Gnielinski (GN) in Table 2.4. Since a heat transfer correlation affects only the wall temperature of the heated section and does not change the natural circulation potential, the total natural circulation flow rate and the inlet bulk temperature are the same for the two different correlations. It should be noted that due to the high heat transfer rate of the helical type heat exchanger and its conservative design, the impact of a heat transfer correlation on the heat exchanger side is 
minimal; therefore the effect on the prediction of natural circulation flow rate is negligible. Minus signs in the table indicate that a RELAP5-3D prediction significantly underpredicts the experimentally measured values.

The table and Figure 2.23 show that a wall temperature prediction with the Gnielinski correlation yields a closer match with the measured wall temperature compared to the Dittus-Boelter predictions. However, RELAP5 with the Gnielinski correlation still underpredicts the wall temperature by up to over $250 \mathrm{~K}$. This is not a surprising result since Figures 2.20 and 2.21 have shown that the measured HTC could have up to $70 \%$ reduction from the normal turbulent heat transfer value when the loop is operating in the DTHT regime.

However, the behavior of the discrepancy in mass flow rate prediction by RELAP5-3D and the experiment is an interesting subject to discuss. The mass flow rate is strictly estimated from a balance between the buoyancy driving force and the hydraulic resistance of the system. Therefore, the discrepancy in the mass flow rate can occur for two reasons. One is the error in the prediction of buoyancy driving force, which can be due to the error in the calculation of the strength of the heat sink, and the other is the error in the calculation of the total flow resistance of the system, which can be due to the error in predicting the friction factor or form losses.

Figure 2.24 shows the mass flow rate error with respect to the inlet bulk temperature difference for all seven runs. The figure illustrates that there is no strong correlation between the mass flow rate error and the inlet bulk temperature. The inlet bulk temperature affects the driving buoyancy force because it determines the cold leg density and thus the downcomer gravity head, which is the major driving force of the natural circulation inside the loop. Therefore, we can reach the conclusion that the discrepancy in the flow rate is not due to the error in the estimation of the buoyancy head that drives natural circulation. 


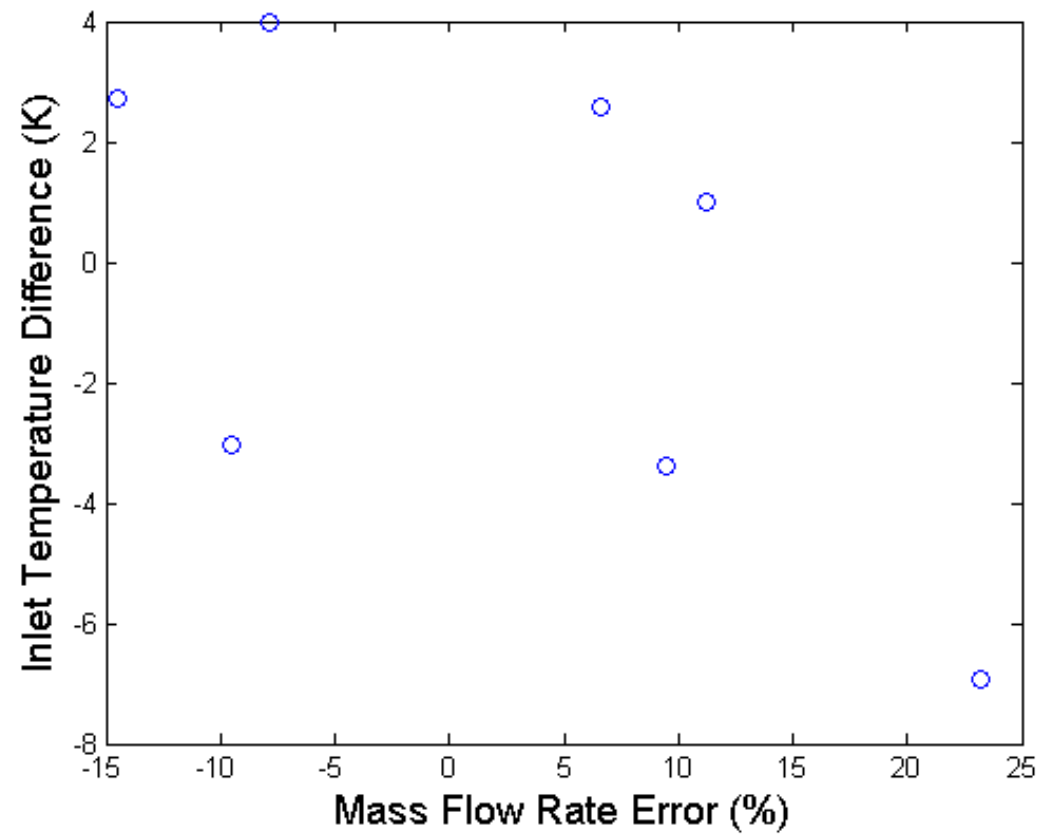

Figure 2.24: Inlet Bulk Temperature Difference vs. Mass Flow Rate Error

Figures 2.25 and 2.26 plot the mass flow error versus the inlet buoyancy and acceleration parameters, respectively. Figures 2.25 and 2.26 show that there is a stronger correlation between the mass flow rate error and the inlet buoyancy parameter or the inlet acceleration parameter than the inlet bulk temperature difference (Figure 2.24). This indicates that a connection between the flow resistance and the strong heating can be a more reasonable candidate for explaining the mass flow rate discrepancy between RELAP5-3D and the experiment than the error in the calculation of the strength of the heat sink, since the effects of the heat sink on both parameters are small. 


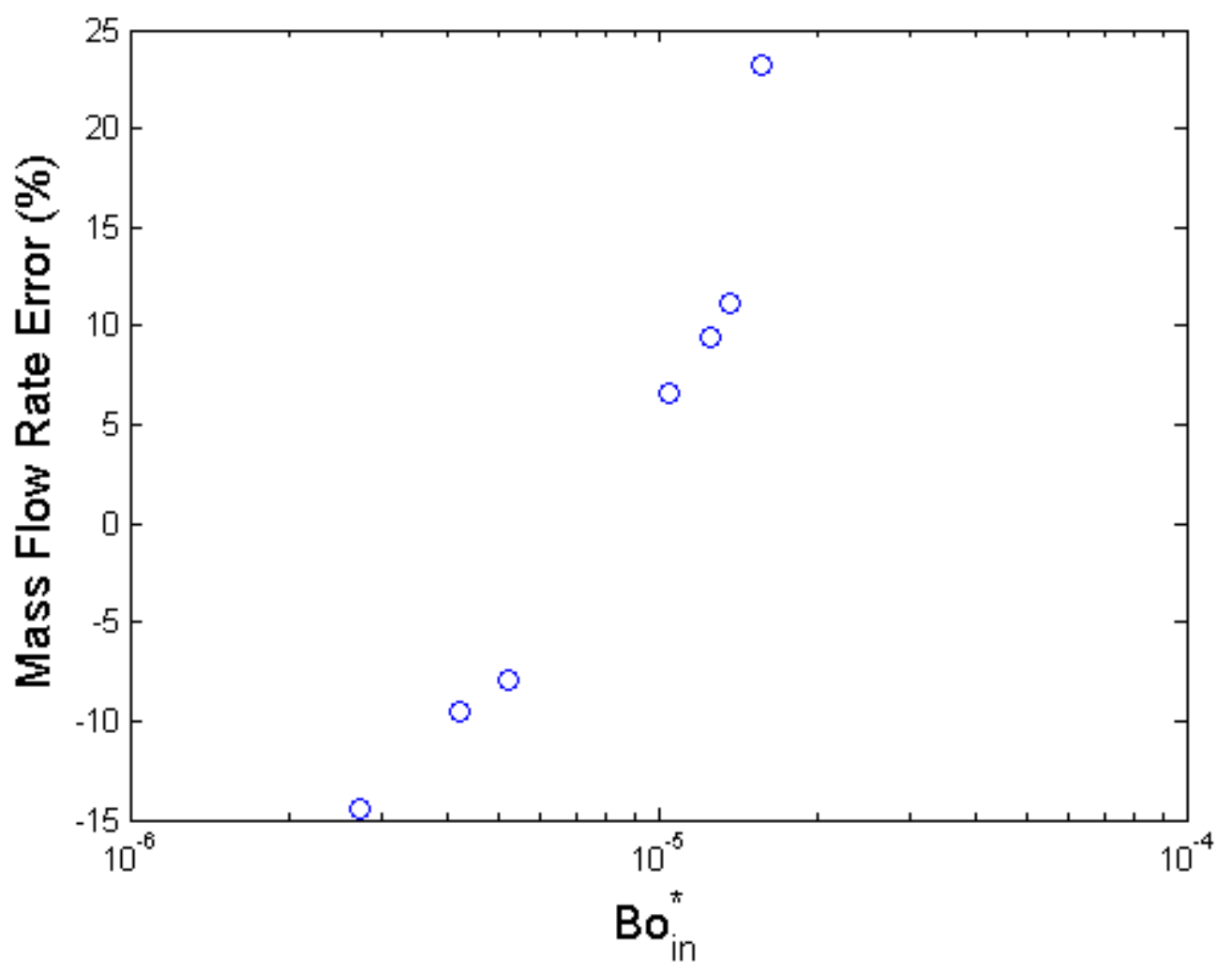

Figure 2.25: Mass Flow Rate Error vs. Inlet Bo ${ }^{*}$

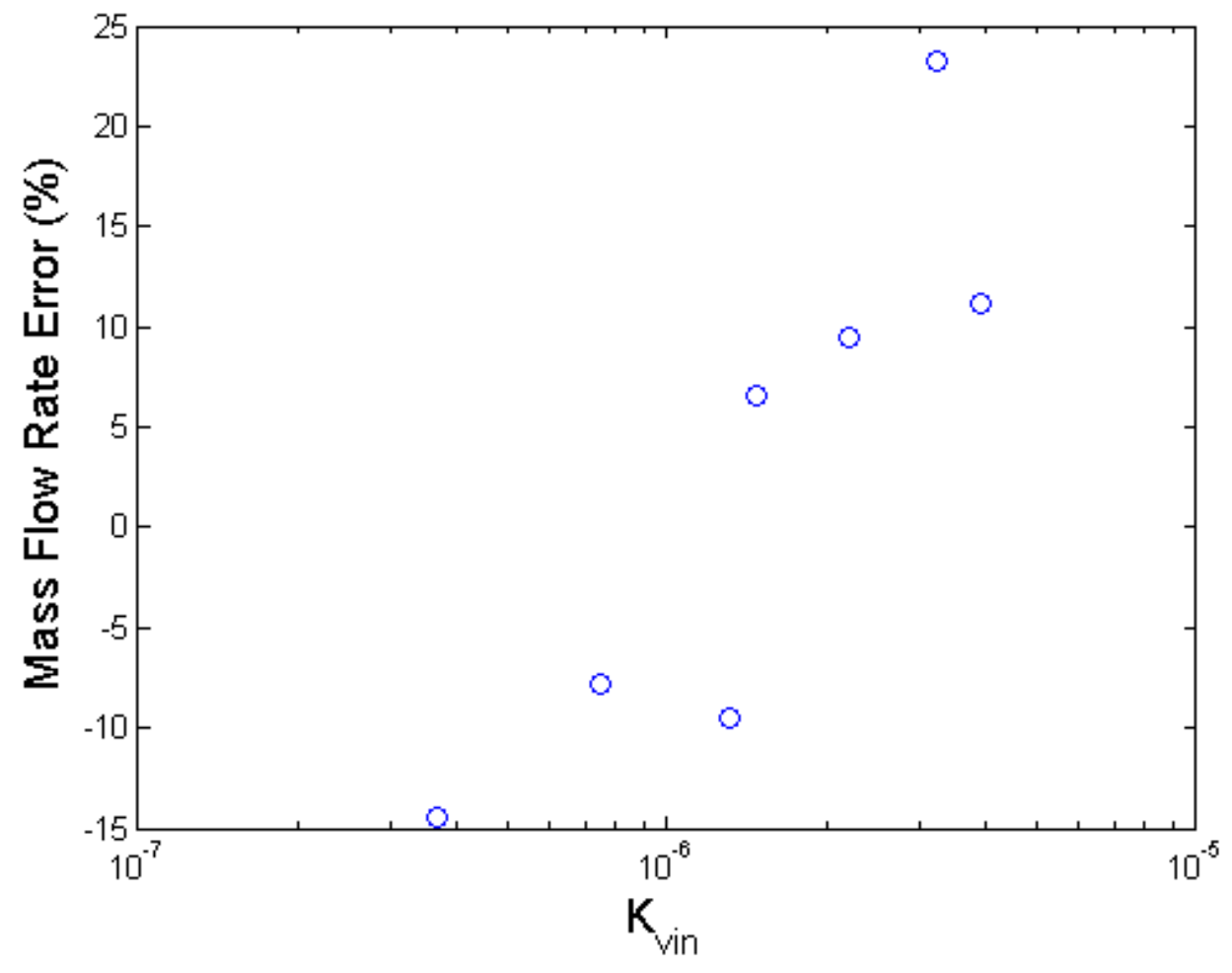

Figure 2.26: Mass Flow Rate Error vs. Inlet $K_{v}$ 
Figure 2.27 shows measured data for friction factors in the test section for each test. The $\mathrm{Y}$-axis shows the ratio of the measured average channel friction factor in the test section to the friction factor calculated from the Blasius correlation based on the inlet Reynolds number, and the X-axis is the inlet buoyancy parameter. Since all seven cases were operated in the buoyancy driven DTHT (Figure 2.20), the inlet buoyancy parameter is selected for an indicator to represent the strong heating effect. The Blasius correlation is selected since it fits well for low Reynolds numbers (around $\mathrm{Re}=4,000$ ), which is close to our operating range, and it is well validated for the forced turbulent condition.

$$
f_{\text {Blasius }}=0.316 / \operatorname{Re}^{0.25}
$$

It can be seen that as the local buoyancy force increases, the average friction factor in the test section increases as well. This can be due to a steeper velocity gradient near the heated wall caused by a large buoyancy force.

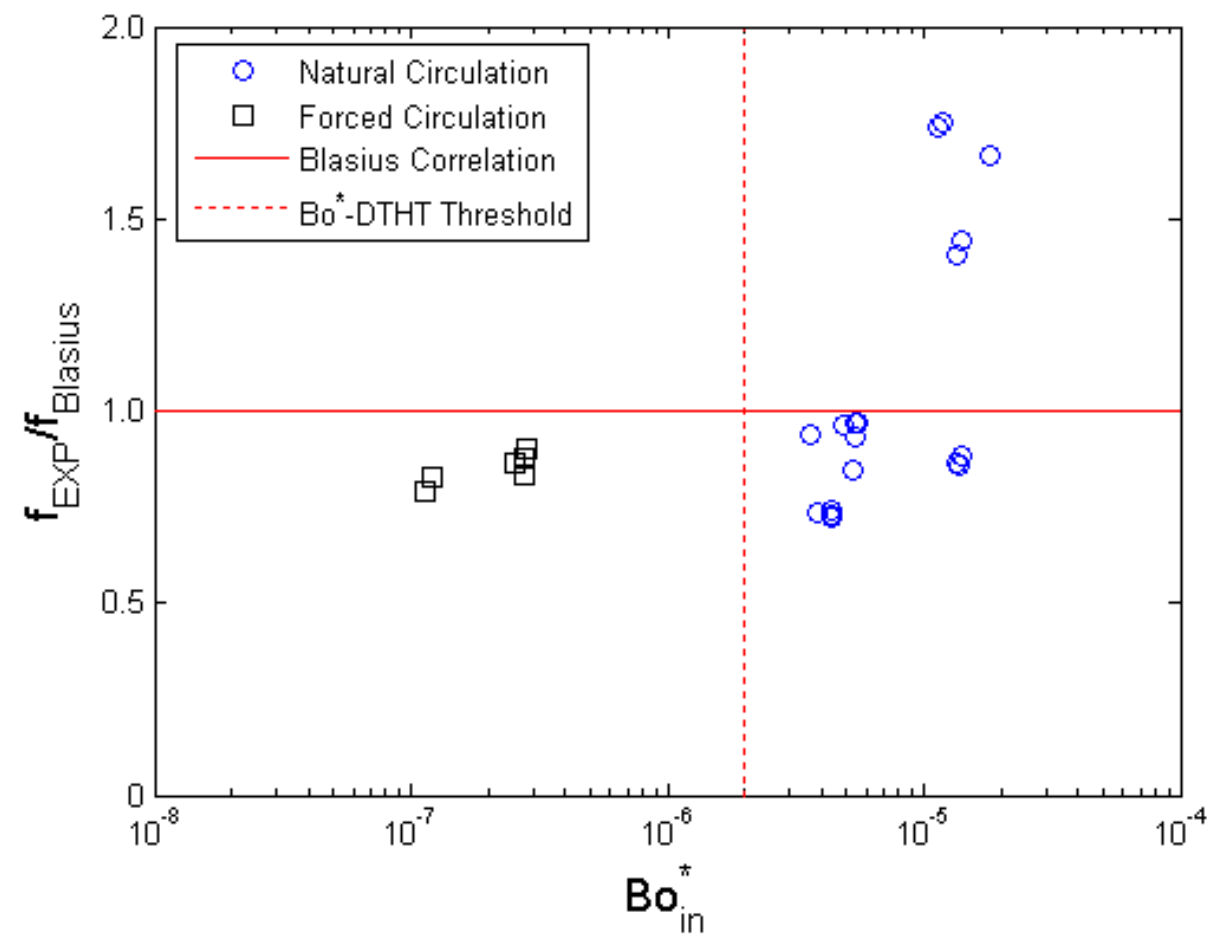

Figure 2.27: Friction Factor Measurement Ratio vs. Local Bo*

Therefore, the discrepancy in the mass flow rate between the RELAP5-3D and the data comes from the lack of a friction factor correlation in gas flow that can increase by up to $70 \%$ due to the large buoyancy forces. It should be noted that RELAP5-3D has a capability of modeling the friction factor change for water as an operating fluid when the property modification is large due to the heating, but this option is not available for the gas. Moreover, since the gas property modification tends to lower the turbulent heat transfer and the skin friction for heated flow (e.g. Eq.(2-1)), this option would decrease 
the gas friction factor, which is the opposite effect to that observed in this experiment under large buoyancy and acceleration forces. In addition, the behavior of friction factor shown in Figure 2.27 cannot be easily explained by the well-known Reynolds' analogy, where the analogy shows that the turbulent friction factor and the HTC should behave similarly, while in our runs the heat transfer is significantly deteriorated and the friction factor is increased, which behaves oppositely.

The above comparisons indicate that employing forced turbulent heat transfer and friction factor correlations for the naturally circulating gas flows may lead to substantial underpredictions of wall temperatures when the system is operating in the DTHT regime. Thus, to improve wall temperature predictions in the DTHT regime, appropriate friction factor and heat transfer correlations in the DTHT regime are necessary. In fact, the motivation for this program was to obtain data in the DTHT regime and develop heat transfer correlations for this regime that could be incorporated into RELAP5-3D to improve predictions in this regime.

\subsubsection{Numerical Predictions using LOCA-COLA}

Because the source code of RELAP5-3D was not available to us to implement the new MIT correlation from Eqs. (2-2) through (2-5), which covers DTHT regimes, LOCA-COLA (Loss of Coolant Accident - Convection Loop Analysis) an in-house computer code for steady state analysis of generic gas convection cooling systems (2-16), was used for another set of comparisons. LOCA-COLA originally employed a set of heat transfer correlations that cover forced, mixed and free convection regimes (buoyancy driven DTHT). The Gnielinsky correlation is employed in the forced convection regime and Churchill correlations (2-9) were used for mixed and free convection regimes (buoyancy driven DTHT). A linear interpolation approach was used in the transition between forced and mixed convection to obtain a smooth transition. The new MIT correlation from Eqs. (2-2) through (2-5) was implemented in LOCA-COLA and evaluated against experimental data from Runs in Table 2.3. It is important to note that these new data in Table 2.3 were not part of the data set used to develop this correlation.

The comparison for Run 5 is plotted in Figure 2.28. In the legend, "Org." implies the Churchill correlation originally implemented in the code, and "MIT" implies the new correlation developed at MIT. Table 2.5 provides a summary of differences between predictions and experiments for 4 selected runs. It should be noted that the first two points in the thermally developing region and the last two points have significant axial heat loss and high uncertainties; thus they are not included for calculating the MAX $\Delta T$ in Table 2.5. Comparing the mass flow rate differences in Table 2.5 to those in Table 2.4, it is clear that even though the differences are slightly smaller for LOCA-COLA than for RELAP5-3D, the trend in discrepancies is the same. This confirms that even a more accurate treatment of friction factor in the transition regime is not sufficient to predict flow rates accurately, unless the effect of buoyancy effect on friction factor is incorporated into the model. Nevertheless, overall the prediction of mass flow rate is reasonable and error does not exceed $20 \%$. 


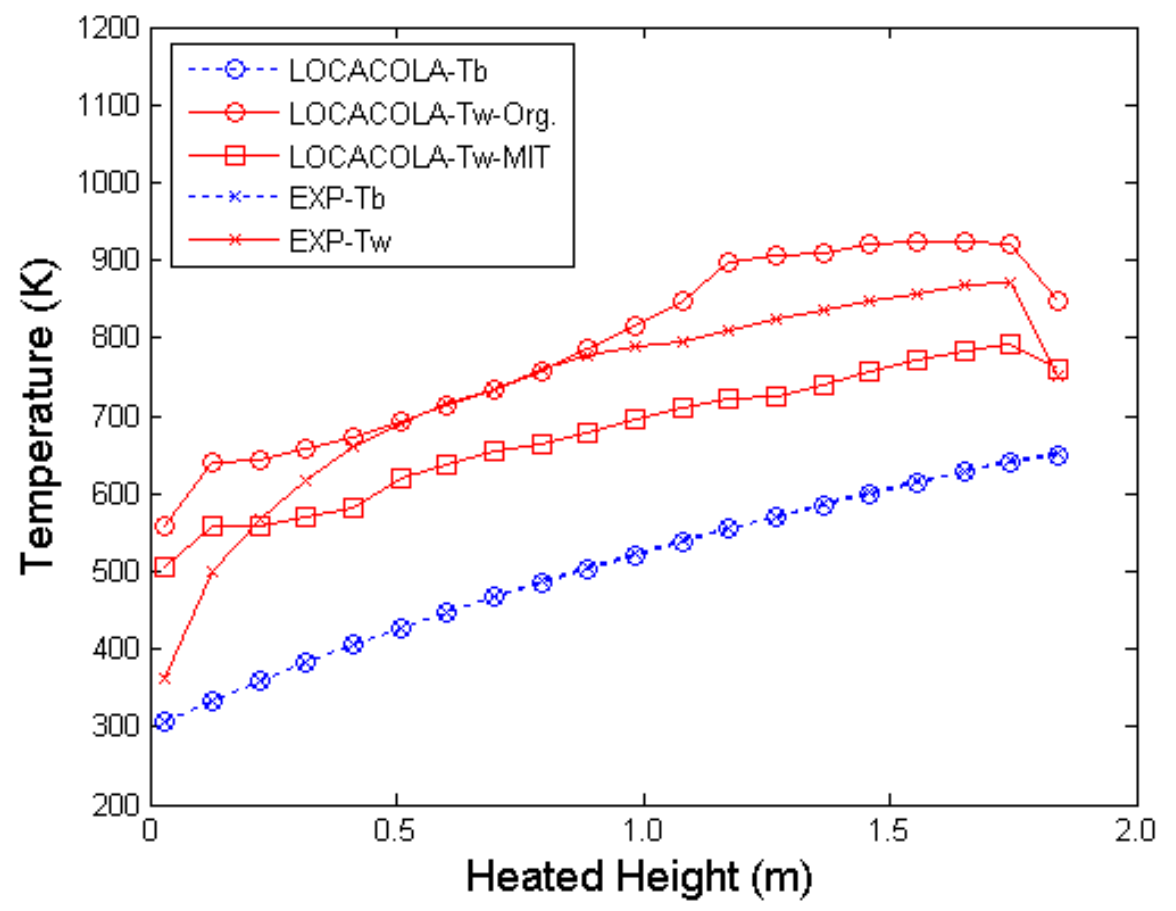

Figure 2.28: RUN \#5 Experimental Data vs. LOCA-COLA

Table 2.5: Summary of LOCA-COLA Results

\begin{tabular}{|c||c|c|c|c|}
\hline \multirow{2}{*}{ Run \# } & $\begin{array}{c}\text { Mass Flow Rate } \\
\text { Error (\%) }\end{array}$ & \multicolumn{2}{|c|}{$\operatorname{Inlet} \Delta \mathrm{T}_{\mathrm{b}}(\mathrm{K})$} & \multicolumn{2}{|c|}{ Max $\Delta \mathrm{T}_{\mathrm{w}}(\mathrm{K})$} \\
\cline { 4 - 5 } & 16.7 & & Original & MIT \\
\hline 1 & 7.2 & 0.4 & 240.0 & 127.0 \\
\hline 4 & 0.6 & 2.0 & 68.0 & 72.0 \\
\hline \hline 5 & -12.4 & 0.5 & 99.0 & -81.0 \\
\hline \hline 6 & 0.4 & 158.0 & -150.0 \\
\hline
\end{tabular}

Comparing maximum differences in cladding temperatures in Table 2.5, interesting trends can be observed. First, the underprediction of the original correlation set in LOCA-COLA ("LOCACOLA-Tw-Org.") is smaller than for RELAP5-3D using solely the Gnielinski correlation. Nevertheless, the reduction in HTC in the experimental facility is larger than that predicted by Churchill's approach ("Org."). Secondly, although the MIT correlation reduces the differences and is significantly more conservative than the original correlation, it still does not guarantee conservative predictions for all cases. This can be seen in Run \#1, which has very high values for both the buoyancy and acceleration numbers and where the peak clad temperature is underpredicted by $127^{\circ} \mathrm{C}$. This large discrepancy is partly caused by overprediction of mass flow rate due to the 
absence of the correct friction factor correlation for the DTHT regime (see Figure 2.27). This can be also supported by the "LOCACOLA-Tw-Best", where the mass flow rate was matched closer to the experimental value by adjusting the form losses. The peak wall temperature difference is now reduced from $127^{\circ} \mathrm{C}$ to $92^{\circ} \mathrm{C}$, which corresponds to a $25 \%$ error on wall-to-bulk temperature difference. Thus, the compounded effect of the absence of correct friction factor correlations in the DTHT regime is significant. Thirdly, the wall temperature profile along the heated length is not predicted well in some cases. This is not surprising, given the various phenomena that drive heat transfer deterioration, as discussed in Lee et al. (2-11), while the Type-3 MIT correlation is a simplified correlation that lumps all these effects into one parameter - non-dimensional heat flux, $\mathrm{q}^{+}$. Also, these runs are new runs that were not part of the original data set used for the correlation development. Even more importantly, the data used for MIT correlation development did not have a case with both the acceleration and buoyancy parameters so far above their thresholds at the same time as for Run \#1. Therefore, more work would be needed to improve the correlation to cover such extreme cases.

Nonetheless, even though the $127^{\circ} \mathrm{C}$ cladding temperature underprediction is large, it will be difficult to reduce this uncertainty significantly. This stems from the fact that the HTC in low gas flows is small and even a small uncertainty on HTC projects to large wall temperature differences for a given bulk temperature. For example, the MIT correlation correlates data from 50 runs to within a $20 \%$ uncertainty band. Since the HTC in the DTHT regime for run $\# 1$ is about $10 \mathrm{~W} / \mathrm{m}^{2}-\mathrm{K}$ and heat flux at the location of peak clad temperature is $3000 \mathrm{~W} / \mathrm{m}^{2}, 20 \%$ uncertainty in HTCs projects to a $\pm 75^{\circ} \mathrm{C}$ difference on cladding temperature. On the other hand, the $20 \%$ uncertainty on water HTC of $20,000 \mathrm{~W} / \mathrm{m}^{2}-\mathrm{K}$ at a typical decay heat flux of $60,000 \mathrm{~W} / \mathrm{m}^{2}$ results in a cladding temperature change of less than $1^{\circ} \mathrm{C}$. Since the Gnielinski correlation, which is one of the best correlations available for forced turbulent convection regime, correlates data within a $20 \%$ uncertainty band, it is evident that a further reduction of uncertainties in the DTHT regime, which is one of the major characteristics of natural-circulation gas cooled systems, is limited.

\subsubsection{Conclusions from Heat Transfer Experiments}

Several key conclusions impacting the design of passive decay heat removal systems based on gas natural circulation were drawn from this study of DTHT in naturally circulating gas flows:

- Natural circulation gas loops can operate in acceleration driven or buoyancy driven or both-effects-driven DTHT regimes with substantial reduction of heat transfer coefficient (HTC): as low as $30 \%$ of its forced convection value. Hence, most computer codes with traditional turbulent heat transfer correlations that do not have the capability to simulate the buoyancy and acceleration effects on turbulent heat transfer will significantly underpredict wall temperature in DTHT regimes.

- Friction factor in forced circulation heated flow is reduced in comparison to that of isothermal flow, leading to slight underprediction of achievable flow rates in this 
regime. However, once the flow enters the DTHT regime, either buoyancy or acceleration controlled or both, friction factor will significantly increase (by up to $70 \%$ in our experiment), resulting in a significant underprediction of achievable mass flow rates.

- Reduction of friction factor in the buoyancy and acceleration driven DTHT flows significantly exacerbates the heat transfer impairment by further reducing the natural circulation flow rate and increasing the heat flux to flow ratio and both the acceleration and buoyancy effects.

- Helium is expected to have different behavior because flow rates achievable through natural circulation are in laminar or very close to laminar flow, so the flow cannot be further "laminarized" by acceleration or buoyancy forces. On the contrary, the high buoyancy will cause flow turbulization and enhancement of heat transfer. However, friction factor will increase and because the cladding temperature in helium cooled channels under natural circulation is more sensitive to the mass flow rate than for heavy gas coolants, such as $\mathrm{CO}_{2}$ or $\mathrm{N}_{2}$, the impact on cladding temperature may be significant. Experiments with helium are necessary to confirm this hypothesis.

- The limited friction factor data obtained in the facility are by far not sufficient for the development of reliable correlations, and more experimental data and research is needed to quantify the effects of the buoyancy and acceleration on friction factor in the DTHT flows. Also, further improvements in the MIT correlation are desirable, but we do not expect that cladding temperature predictions could be improved to within a few degrees centigrade, as in water cooled and liquid metal cooled reactors, due to inherently low gas HTCs and consequently larger uncertainties of the effects of phenomena impairing heat transfer in DTHT regimes.

These conclusions supported the decision to employ blower-driven forced circulation of $\mathrm{CO}_{2}$ with the resulting well defined heat transfer regime for decay heat removal as a primary line of defense. This is because, in addition to the difficulties of overcoming core bypass issues without employment of uneconomically large distances between thermal centers of cooling loops, the uncertainties in the prediction of peak cladding temperatures are unacceptably large. Moreover, these uncertainties stem from the very small heat transfer coefficients of low-pressure, low-flow gas flows along high heat-flux surfaces and cannot be overcome because of limitations on practically achievable uncertainties of heat transfer correlations under these conditions. 


\subsection{Improved Emergency Power Provisions}

\subsubsection{Section Foreword}

Due mainly to the low volumetric heat capacity $(\rho \mathrm{Cp})$ and heat transfer coefficient of gas coolants, combined with the low $\rho \mathrm{Cp}$ /power density ratio of fast reactor cores, GFRs are particularly vulnerable to unprotected transients: e.g. ULOF, ULOCA, UTOP, and ATWS in general. Such events are also precursors to core disruptive accident (CDA/HCDA) scenarios, which are difficult to analyze and to cope with. Thus a principal goal of the present work has been to achieve a very high level of reliability for provision of both on-site emergency power and reactor scram. This section summarizes work on this and precursor projects dealing with provision of emergency power, hence avoidance of station blackout.

\subsubsection{Emergency Power Supply Options}

This issue was addressed both prior to and early-on in the present project. A variety of possible approaches were surveyed for task-specific suitability. The results are summarized in Table 2.6 A principal conclusion was that fuel cells merited consideration as a supplement to, or replacement of, the diesel-generators conventionally employed.

There are several advantages to use of fuel cells:

(1) Fewer moving parts. Whereas a heavy duty diesel engine has around 3000 parts and 600 part numbers (2-17), a fuel cell has far fewer, and a passive pressurized $\mathrm{H}_{2}$ tank fuel supply.

(2) Amenability to constant-on (at low power) operation which:

(a) replaces failure to cold-start by failure to ramp-up, which should be considerably smaller

(b) provides continuous diagnostic signals, assuring readiness to perform or indication of system degradation

(3) Use of hydrogen as fuel, which is already handled on site for generator cooling, and, in the case of LWRs, for primary coolant water chemical treatment. It is also readily generated by commercially available pre-packaged water electrolysis units. 
Table 2.6: Rating of Candidates for Emergency Power Supply

\begin{tabular}{|c|c|c|c|c|c|c|}
\hline \multirow[t]{2}{*}{ System } & \multicolumn{5}{|c|}{$\begin{array}{l}\text { Characteristics Rating } \\
(\text { Low }=1 \text {, to High }=5)\end{array}$} & \multirow{2}{*}{$\begin{array}{l}\text { Overall } \\
\text { Weighted } \\
\text { Rating }\end{array}$} \\
\hline & SOD & PSI & WOA & SED & LHR & \\
\hline $\begin{array}{l}\text { Diesel } \\
\text { Generators }\end{array}$ & 4 & 1 & 3 & 5 & 3 & 63 \\
\hline Fuel Cells & 3 & 2 & 5 & 5 & 4 & 77 \\
\hline Microturbines & 4 & 2 & 5 & 5 & 3 & 74 \\
\hline $\begin{array}{l}\text { Small Heat Engines } \\
\text { (Stirling, Brayton) }\end{array}$ & 4 & 1 & 2 & 5 & 2 & 54 \\
\hline $\begin{array}{l}\text { Superconducting } \\
\text { Magnet }\end{array}$ & 3 & 2 & 2 & 2 & 4 & 50 \\
\hline Steam Storage & 4 & 1 & 1 & 3 & 3 & 45 \\
\hline $\begin{array}{l}\text { Compressed Gas } \\
\text { Storage }\end{array}$ & 4 & 1 & 1 & 3 & 3 & 45 \\
\hline $\begin{array}{l}\text { Large Chemical } \\
\text { Batteries }\end{array}$ & 2 & 2 & 1 & 4 & 4 & 54 \\
\hline $\begin{array}{l}\text { Thermoelectric } \\
\text { Generators }\end{array}$ & 2 & 4 & 2 & 5 & 4 & 69 \\
\hline Flywheels & 4 & 1 & 2 & 2 & 3 & 44 \\
\hline Ultracapacitors & 3 & 2 & 3 & 2 & 4 & 54 \\
\hline $\begin{array}{l}\text { Importance Weighting } \\
\text { of Characteristic }\end{array}$ & 2 & 3 & 4 & 5 & 5 & $\begin{array}{l}\text { Max } \\
=95\end{array}$ \\
\hline Key: $\begin{array}{l}\text { SOD }=\text { State of } \\
\text { PSI }=\text { Potentia } \\
\text { WOA }=\text { Widesp } \\
\text { SED }=\text { Stored } \\
\text { LHR }=\text { Likelih }\end{array}$ & $\begin{array}{l}\text { develo } \\
1 \text { for si } \\
\text { read otl } \\
\text { nergy } \\
\text { od of } 1\end{array}$ & $\begin{array}{l}\text { omen } \\
\text { snific } \\
\text { er ap } \\
\text { lurati } \\
\text { igh re }\end{array}$ & $\begin{array}{l}\text { nnt impr } \\
\text { olicatior } \\
\text { on (e.g. } \\
\text { liability }\end{array}$ & $\begin{array}{l}\text { oveme } \\
72 \text { houl } \\
\text { is }\end{array}$ & & \\
\hline
\end{tabular}

It is recognized that fuel cells are a work in progress, but commercial backup power applications employing fuel cells are currently in use. Thus in the time frame likely for fast reactor deployment, suitable units should be available off-the-shelf. In view of the fact that diesel generator reliability has improved over the years, a wait-and-see policy would appear appropriate, particularly since other GFR enablement initiatives have significantly higher priority. Nevertheless, since site backup power is a universal issue, a generic R\&D project in this area would appear justifiable. 


\subsection{Shutdown Assurance}

\subsubsection{Downselection of Basic Approaches}

The first lines of defense in this area are the inherent characteristics built into the core and the diversity and redundancy of the reactivity control system, namely:

(1) A negative coefficient of coolant void reactivity - rare in fast reactors, achieved by use of a moderating diluent $\mathrm{BeO}$, and high void $\left(\mathrm{CO}_{2}\right)$ content radial reflector assemblies

(2) A balanced ensemble of reactivity feedback coefficients in the IFR sense, which assures self-protection

(3) Two separate control rod/scram systems, with functionally different drive mechanisms: e.g. electromechanical and pneumatic.

However, contemporary fast reactor designers are introducing a third layer of supplementary features to achieve even higher assurance of scram. We have surveyed a spectrum of such devices, and assigned ratings to their performance attributes, as summarized in Table 2.7. As shown, the lithium expansion module (LEM) and the flowlevitated absorber (FLEA) score highest. Thus use of one, or both, is prescribed should an in-depth PRA not provide sufficient protection against CDA scenarios.

The lithium expansion module (LEM) should be familiar from the extensive Japanese work on this concept. At MIT most of our attention to this approach has been in the context of a liquid salt cooled fast reactor, but performance behavior would appear to be directly transferrable. The LEM also appears to react slower than the flow-levitated absorber (FLEA) developed at MIT. As shown in Fig. 2.29, the FLEA consists of an absorber slug suspended by core pressure drop in a tube passing vertically through the core. Thus both LOF and LOCA events allow the absorber to fall back down into the core. Passivity, diversity and redundancy are also readily built into a suite of such devices. Most are located in the inner row of radial reflector assemblies. Recall that the radial reflector is essentially a "void" filled with $\mathrm{CO}_{2}$, which in the event of LOCA helps create a negative reactivity insertion. Thus it is configurationally and compositionally compatible with insertion of a bundle of (thin-wall, usually empty) FLEA tubes into a reflector assembly duct. 


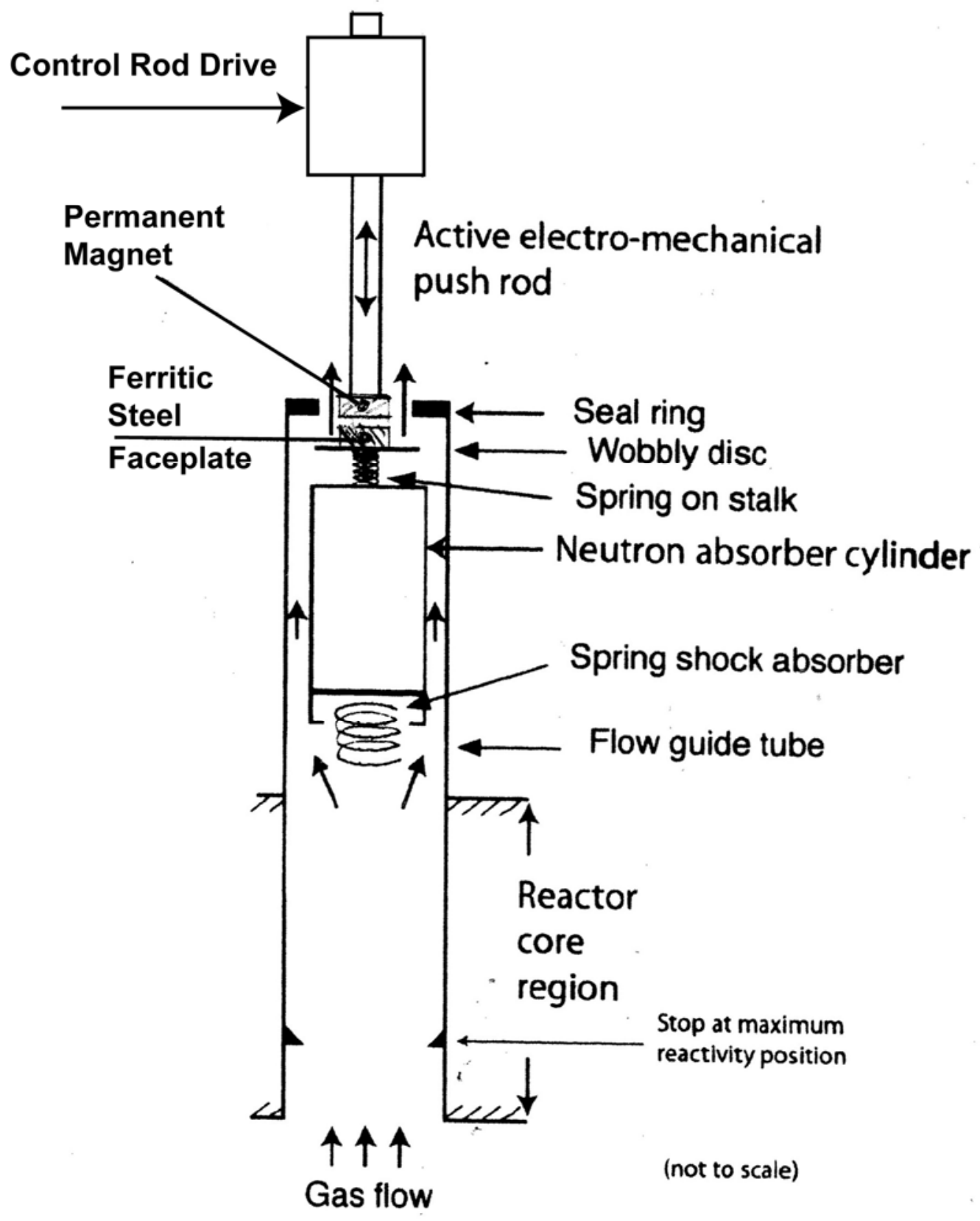

Figure 2.29: Flow Levitated GFR Reactivity Shutdown Device 
Table 2.7: Rating of Candidates for Emergency Scram Supplementation

\begin{tabular}{|c|c|c|c|c|c|}
\hline \multirow[b]{2}{*}{ Concept } & \multicolumn{4}{|c|}{$\begin{array}{l}\text { Characteristics Rating } \\
(\text { Low }=1 \text {, to High = 5) }\end{array}$} & \multirow[b]{2}{*}{$\begin{array}{l}\text { Overall } \\
\text { Weighted } \\
\text { Rating } \\
\end{array}$} \\
\hline & DOP & SER & ROA & SOD & \\
\hline $\begin{array}{l}\text { Lithium Expansion } \\
\text { Module (LEM) }\end{array}$ & 5 & 5 & 3 & 4 & 69 \\
\hline $\begin{array}{l}\text { Lithium Injection } \\
\text { Module (LIM) }\end{array}$ & 4 & 1 & 1 & 3 & 37 \\
\hline $\begin{array}{l}\text { Curie Point Latches } \\
\text { On Control Rods } \\
\end{array}$ & 5 & 2 & 2 & 4 & 53 \\
\hline $\begin{array}{l}\text { Fusible Link Latches } \\
\text { On Control Rods }\end{array}$ & 5 & 1 & 1 & 4 & 45 \\
\hline $\begin{array}{l}\text { Flow-Levitated } \\
\text { Absorber }\end{array}$ & 5 & 4 & 4 & 4 & $69)$ \\
\hline Reactivity Bangstick & 5 & 1 & 4 & 4 & 57 \\
\hline $\begin{array}{l}\text { Device Pressured } \\
\text { By Alkali Vapor } \\
\end{array}$ & 5 & 5 & 1 & 3 & 58 \\
\hline $\begin{array}{l}\text { Pressure-Activated } \\
\text { CR Scram Latch }\end{array}$ & 5 & 4 & 3 & 4 & 65 \\
\hline $\begin{array}{l}\text { Cartesian Diver/ } \\
\text { Galilean Thermometer }\end{array}$ & 5 & 5 & 2 & 3 & 62 \\
\hline Weight & 5 & 4 & 4 & 3 & $\begin{array}{l}\text { Max } \\
=80\end{array}$ \\
\hline $\begin{array}{l}\text { DOP }=\text { Degree } \\
\text { SER }=\text { Self res } \\
\text { ROA }=\text { Rapidit } \\
\text { SOD }=\text { State of }\end{array}$ & $\begin{array}{l}\text { f passi } \\
\text { tability } \\
\text { of acti } \\
\text { develo }\end{array}$ & nent a & d demo & tration & \\
\hline
\end{tabular}

\subsubsection{Relevant Comparisons}

Assurance of shutdown in the CEA version of the GFR is achieved by:

(1) Two redundant, diverse control rod sets: one electromechanical and the other pneumatic

(2) Provision for dropping in absorber elements

This approach is similar to that employed in the European Fast Reactor (EFR). SPrism also adopts this strategy.

The approach for the MIT GFR is also similar, except that in addition: 
(1) The drop-in absorbers are hydraulically suspended (as for the new Russian BN1800 design), hence are passively actuated in both LOF and LOCA events

(2) Inherent protection is built into the core by adjusting the core composition and configuration to have a suite of reactivity feedback coefficients which insure IFR type post-transient stabilization

(3) The reference core design has high $\mathrm{CO}_{2}$ content reflector assemblies, which, together with the use of $\mathrm{BeO}$ diluent, confer negative void reactivity feedback

(4) Excess coolant (hence clad) temperatures can be further protected against using lithium expansion modules (LEM)

(5) As a last resort, the core can be flooded with water: because of the small coolant volume fraction (27\%) and fuel composition employed, this renders it subcritical

Figure 2.30 shows the applicable reactivity ladder, and the available compensation.

It is therefore anticipated that the probability of failure to shut down, both protected and unprotected, will be at least an order of magnitude lower for the MIT approach than for most other past and contemporary fast reactor designs. 
Intrinsic Reactivity Increments

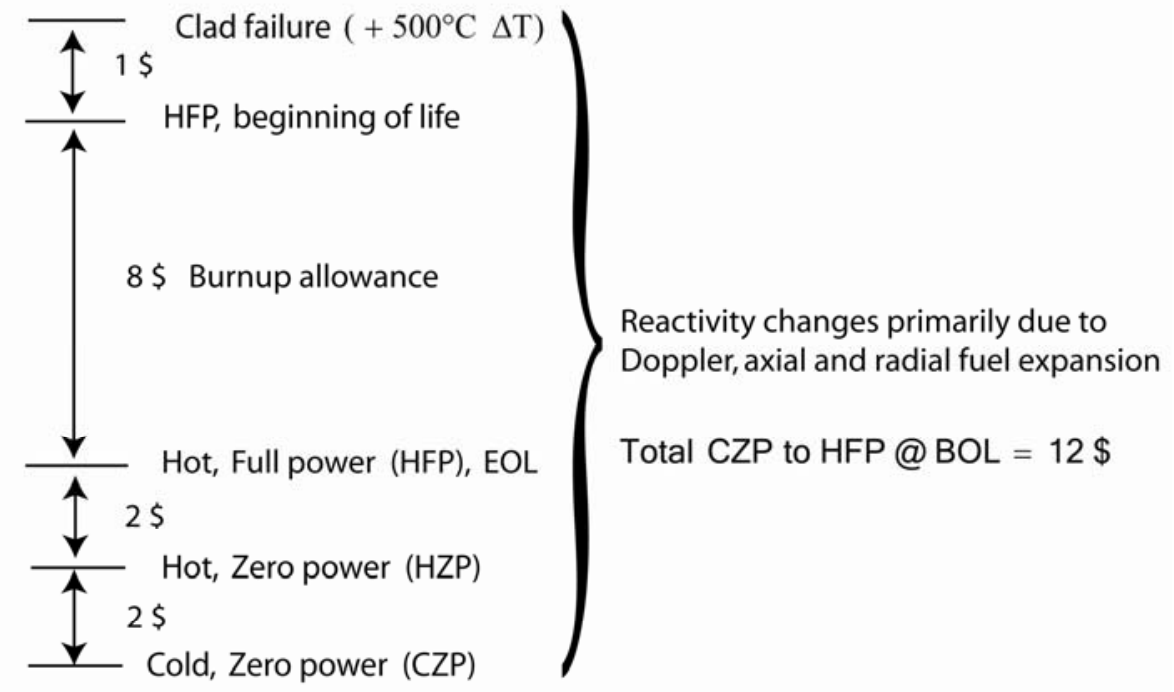

Available Compensation

Standard 19 Control Rods @ 48 cents each; Total = $9 \$$ (in two groups)

12 Flow Levitated Absorbers @ 50 cents each; Total $=6 \$$

( 6 in 1 st reflector row and 6 in mid ring of 2 nd (of 3 ) core zones)

Optional: $\quad 3$ Lithium Expansion Modules: Total $=0.3 \$$ per $100^{\circ} \mathrm{C}$

(per assembly, in place of (above HFP coolant exit T)

hex duct corner vent hence $1.5 \$$ per $500^{\circ} \mathrm{C}$

flow tubes)

$\left.\begin{array}{lr}\text { Post-Accident: Coolant voiding } & -1 \$ \\ \text { Core flooding with } \mathrm{H}_{2} \mathrm{O} & -10 \$\end{array}\right\}$ Features unique to this reactor

\section{Figure 2.30: Reactivity Effects and Their Compensation in MIT GFR}

\subsection{Concluding Discussion}

Reactor shutdown and reliable decay heat removal have been a central theme of project work, and essential to the goal of diminishing (indeed, virtually eliminating) the role of the hypothetical core disruptive accident (HCDA) in the GFR safety feature design process. Instead, mechanistically plausible CDAs are treated as end states of major accident event trees, each of whose stages are subjected to PRA analyses. Large early release frequencies can then be kept below targeted limits such as $10^{-8}$ per reactor year by modifying the plant design. Furthermore, emphasis has been placed on reducing the frequency of initiating events or first-response lines of defense: for example, high scram reliability makes ATWS sequences less plausible overall, and in particular, helps avoid 
unprotected severe transients (ULOF, ULOCA, UTOP, ULOHS), which dominate severe damage scenarios.

An important initiative early-on was maximization of passive safety features. In practice this proved to be more efficacious in the realm of reactor physics design, where IFR-type feedbacks were successfully built-in, and where a high void content radial reflector and flow-levitated absorbers added further avenues of defense. In DHRS design, gas behavior under natural circulation proved to be more fickle, and prompted moving back to active circulation as the mode of principal reliance. Note that the physical properties and phenomena which drove this decision are different for liquids, where natural circulation can well be the justifiable approach.

\subsection{References for Chapter 2}

(2-1) Mackay F.J., Apostolakis G.E., and Hejzlar P., "Incorporating Reliability Analysis into the Design of Passive Cooling Systems with an Application to a Gas-Cooled Reactor," Nucl. Eng. Des., Vol. 238, No. 1, Jan. 2008

(2-2) Bertrand F. et al., "Preliminary Safety Analysis of the 2400 MWth Gas-Cooled Fast Reactor," Proc. of ICAPP'08, Anaheim, June 2008

(2-3) Malo J.Y. et al., "The DHR Systems of the GFR: Preliminary Design and Safety Analysis,” Proc. of ICAPP'07, Nice, May 2007

(2-4) Handwerk, C., Driscoll M.J., and Hejzlar P., "Core Design and Performance Assessment for a Supercritical- $\mathrm{CO}_{2}$ Cooled Fast Reactor,” MIT-ANP-TR-113, May 2007

(2-5) G. Patalano, G. E. Apostolakis, P. Hejzlar, "Risk-Informed Design Changes in a Passive Decay Heat Removal System," Nuclear Technology, Vol. 163, pp. 191208, 2008

(2-6) Idaho National Laboratory, RELAP3-3D@ Code Manual Rev. 2.3, Idaho National Laboratory, INEEL-EXT-98-00834, April 2005

(2-7) Pope M.A., Driscoll M.J., and Hejzlar P., "Thermal Hydraulics of a 2400 MWth Supercritical $\mathrm{CO}_{2}$-Direct Cycle GFR, Massachusetts Institute of Technology, MIT-ANP-TR-112, Sept. 2006

(2-8) Wade, D.C. and Y.I. Chang, "The Integral Fast Reactor Concept: Physics of Operation and Safety," Nucl. Sci. Eng. 100, pp.507-524, 1988

(2-9) Churchill, S.W., "Combined free and forced convection in channels," Heat Exchanger Design Handbook, Begell House, Inc., New York, 2.5.10, 1998.

(2-10) Gnielinski V., "New Equations for Heat and Mass Transfer in Turbulent Pipe and Channel flow", International Chemical Engineering, Vol. 16, No. 2, pp. 359-387, April 1976

(2-11) Lee J. I., P. Hejzlar, P. Stahle, P. Saha, D. M. McEligot, G. E. McCreery and R. R. Schultz, "Design of Thermal-Hydraulic Loop Related to Advanced GasCooled Reactor, Third Annual Report," MIT-GFR-042, INL/EXT-06-11801, Idaho National Laboratory and Massachusetts Institute of Technology, 
Department of Nuclear Science and Engineering, September 2006.

(2-12) Lee J.I., P. Hejzlar, P. Saha and M.S. Kazimi, "Studies of the Deteriorated Turbulent heat Transfer Regime for the Gas-Cooled Fast Reactor Decay Heat Removal System”, Nucl. Eng. Des., Vol. 237, pp. 1033-1045, 2007a.

(2-13) Lee, J.I. and Hejzlar P., "Experimental and Computational Analysis of Gas Natural Circulation Loop", Proc. International Congress on Advances in Nuclear Power Plants ICAPP '07, Paper 7381, Nice, France, May 13-18, $2007 \mathrm{~b}$.

(2-14) Lee J.I., Hejzlar P., Saha P., Stahle P., Kazimi M.S., and McEligot D.M., "Deteriorated Turbulent Heat Transfer of Gas Up-flow in a Circular Tube: Experimental Data", International Journal of Mass and Heat Transfer, Vol. 51, pp. 3259-3266, 2008a.

(2-15) Lee J.I., Hejzlar P., Saha P., Stahle P., Kazimi M.S., and McEligot D.M., "Deteriorated Turbulent Heat Transfer of Gas Up-flow in a Circular Tube: Heat Transfer Correlations", International Journal of Mass and Heat Transfer, Vol. 51, pp. 3267-3273, 2008b.

(2-16) Williams W. C., Hejzlar P., and Saha P., "Analysis of a Convection Loop for GFR Post-LOCA Decay Heat Removal," Paper ICONE12-49360, Proceedings of ICONE12, 12th International Conference on Nuclear Engineering, April 2529, 2004, Arlington, Virginia USA.

(2-17) Perdue, P.L., in "Alternative Transportation Fuels and Vehicles," American Solar Energy Society, Transcript of April 28, 1992 Roundtable, p. 58 


\section{Chapter 3 Task 3: Overall Plant Design and Economic Assessment}

\subsection{Chapter Introduction}

The overall plant design borrows heavily from earlier and contemporary project work. In particular, adoption of the supercritical $\mathrm{CO}_{2}$ Brayton Cycle was a key decision, motivated in large part by the desire to achieve high thermodynamic efficiency and reduce balance-of-plant footprint.

A second set of features, namely the decay heat loops, was significantly influenced by MIT work with ANL/CEA on INERI projects involving the mainline helium-cooled GFR. The principal new contribution is the dual use of water-boiler loops for GFR applications involving high temperature steam electrolysis to produce hydrogen.

Overall, the single most limiting constraint turned out to be significant reliance on natural convection decay heat removal. This limited core power density and led to noncompetitive fuel cycle costs.

\subsection{Power Cycle Design}

In this subtask we were greatly aided by a parallel effort on the $\mathrm{S}-\mathrm{CO}_{2}$ cycle supported through Sandia. That program was focused on a $300 \mathrm{MWe}$ power conversion system (PCS). An important finding was that turbomachinery sizes were small, hence readily extrapolable to higher ratings, but ductwork, in particular, was at or beyond diameters of current industrial practice. Hence even at $300 \mathrm{MWe}$, each turbomachinery train had to be served by a pair of parallel sets of recuperators and ductwork. The obvious choice to employ four PCS units on the $1200 \mathrm{MWe} \mathrm{S-CO} 2$ GFR was eventually discarded (because it required an oversized, hence more expensive, containment building) in favor of two $600 \mathrm{MWe}$ units. This was accomplished by an over-under arrangement of four recuperator/ductwork sets in parallel as shown in Figs. 3.1 and 3.2. 


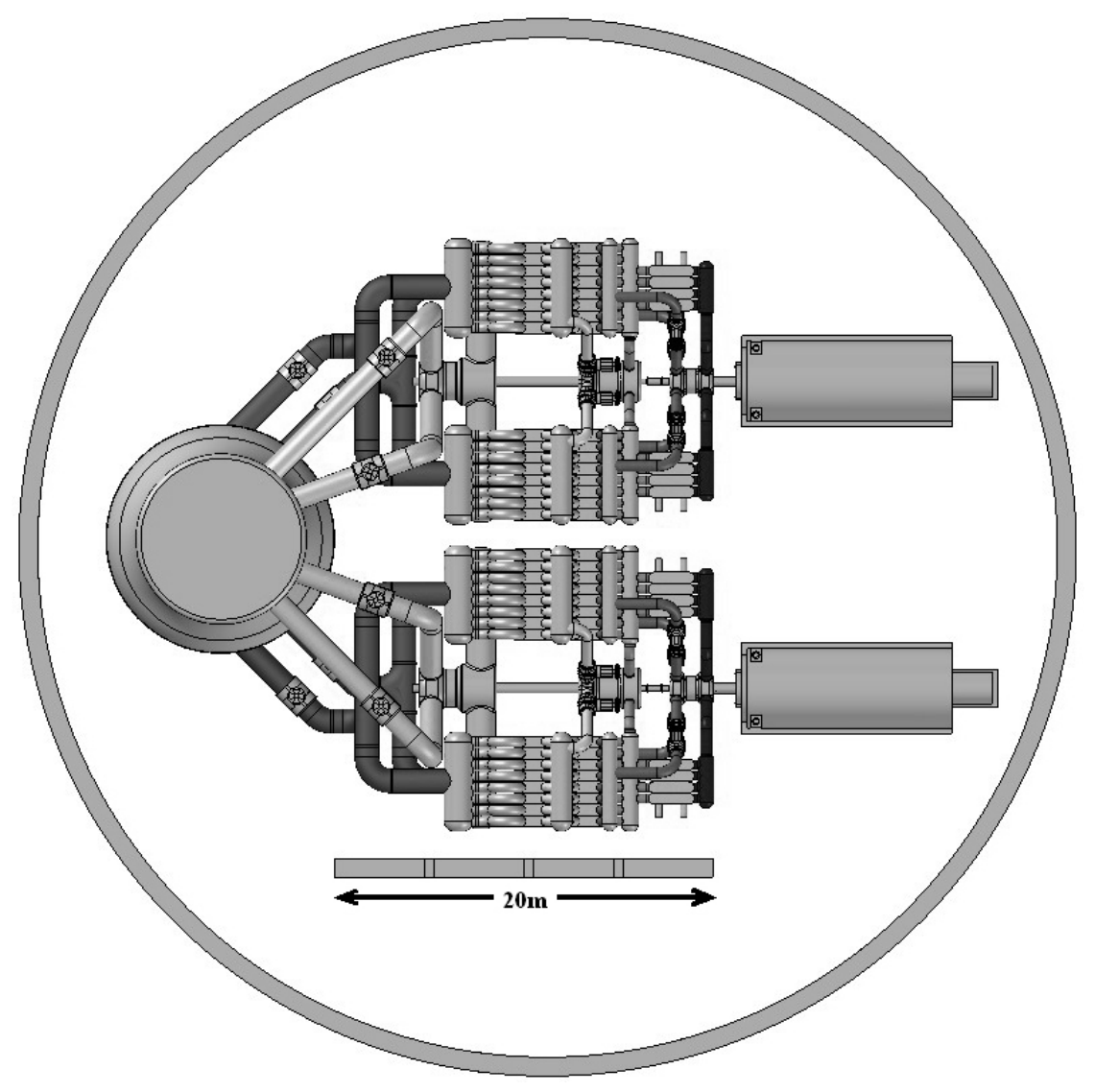

Figure 3.1 1200 MWe 2-Loop Plant Layout (Top View)

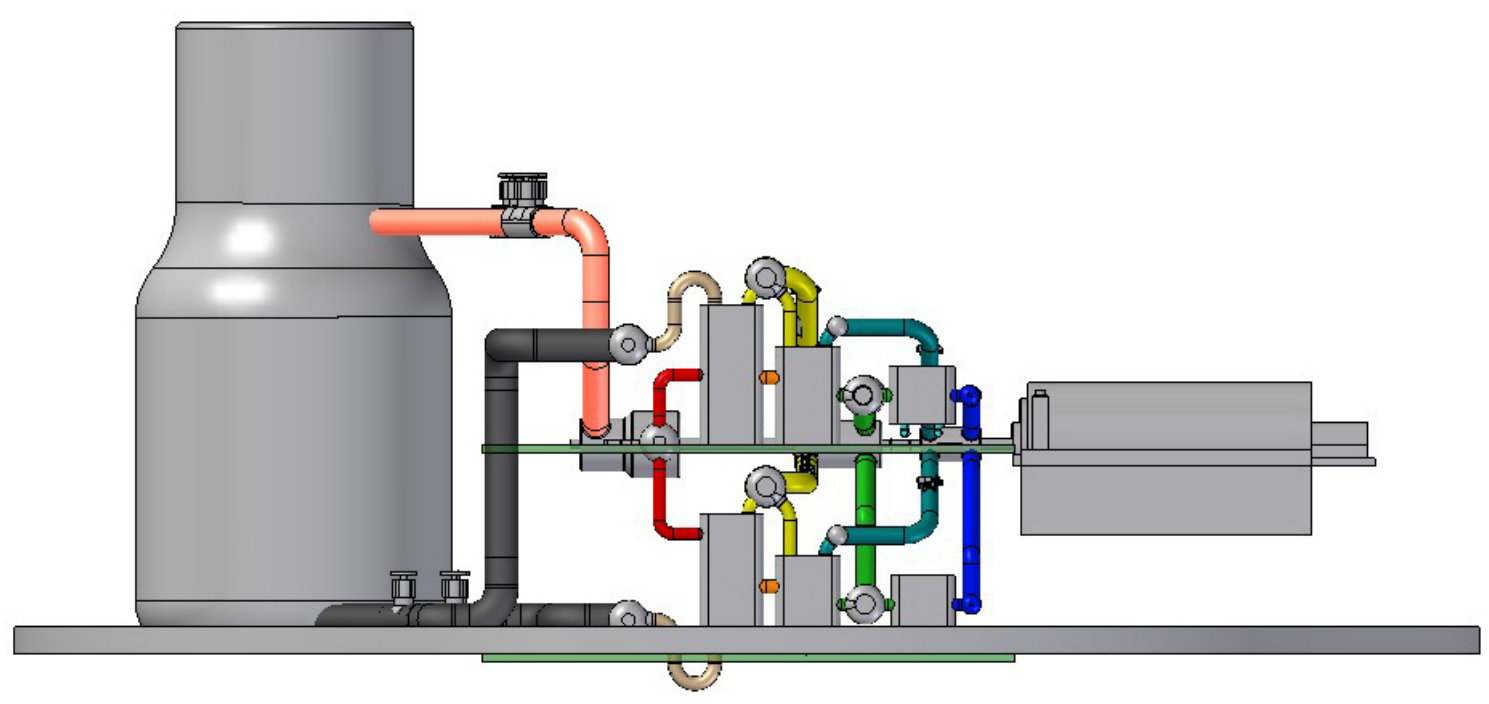

Figure 3.2: $1200 \mathrm{MWe}$ Direct $\mathrm{SCO}_{2}$ Cycle (Side View) 
Figure 3.3 shows the predicted PCS efficiency versus several other candidates. As can be seen, at $650^{\circ} \mathrm{C}$ it is clearly superior. In addition, the figure is based on a $300 \mathrm{MWe}$ turbomachinery train. The larger $600 \mathrm{MWe}$ train's compressors and turbine are more efficient, hence cycle efficiency should be higher, by on the order of $1 \%$.

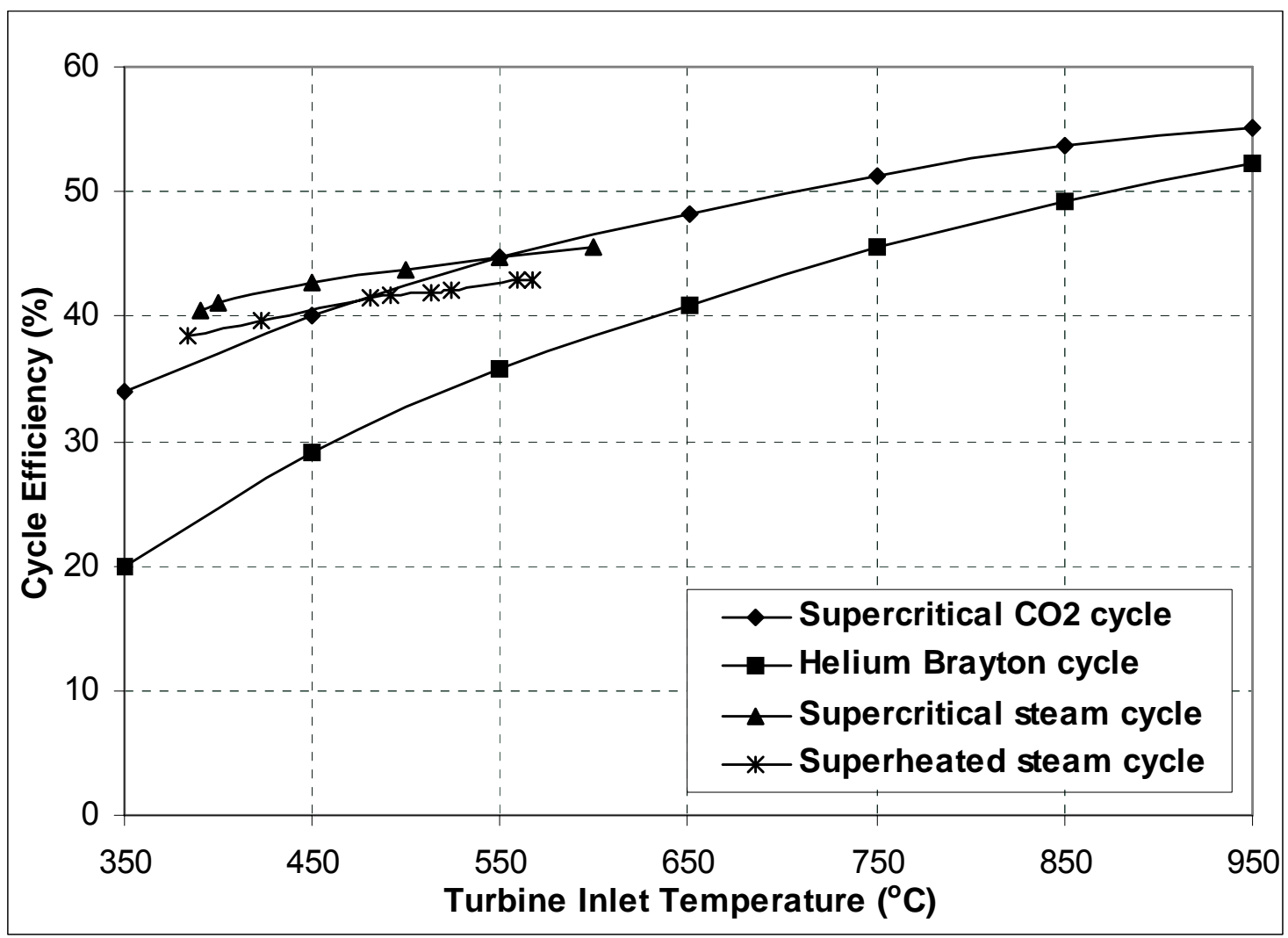

Figure 3.3: Cycle efficiency comparison of advanced power cycles

\subsection{Integration with HTSE Plant for $\mathrm{H}_{2}$ Production}

Production of hydrogen is a major initiative in most countries worldwide who have advanced reactor development programs. In the U.S. two approaches are underway: thermochemical and high temperature steam electrolysis (HTSE). The former requires reactor operation at about $850^{\circ} \mathrm{C}$ - which is a goal of the mainline He-cooled GFR under development by CEA. The MIT-GFR is based on $\mathrm{CO}_{2}$ coolant at $650^{\circ} \mathrm{C}$, which is too cool for thermochemical processing. At first glance this might also appear too low for high temperature electrolysis, since the cells operate at about $800^{\circ} \mathrm{C}$. However, analyses have shown that enough energy can be recuperated from the $\mathrm{H}_{2}$ and $\mathrm{O}_{2}$ product streams to heat steam up to cell inlet conditions. Thus, in principle, any reactor, including LWRs, could be coupled to a HTSE plant. However, since most of the energy needed is still in the form of electricity, high thermodynamic efficiency is essential to overall process 
economy. Thus a GFR driving the supercritical $\mathrm{CO}_{2}$ power conversion system represents a useful compromise: $200^{\circ} \mathrm{C}$ lower operating temperature, but $45 \%$ thermal-to-electric efficiency.

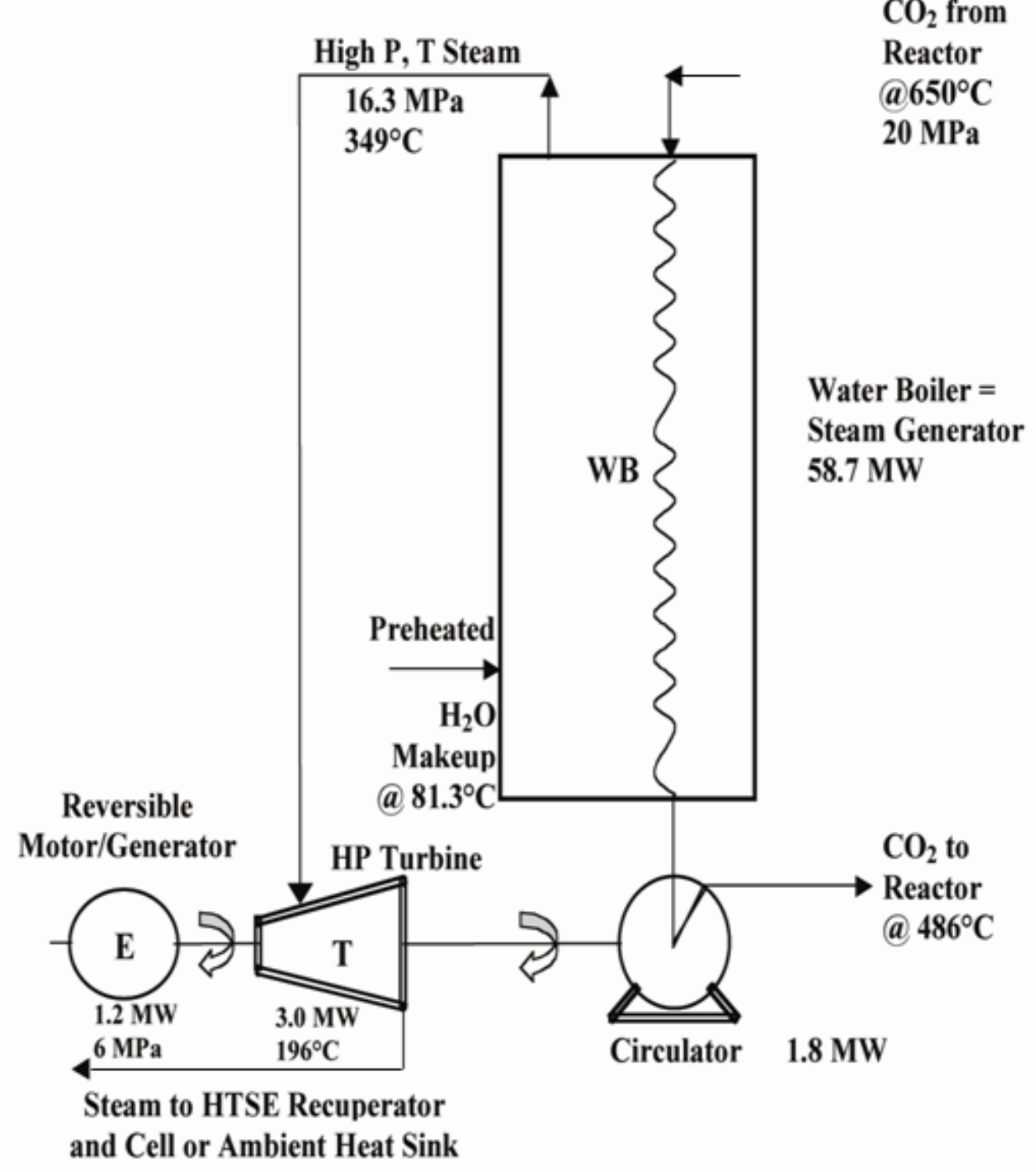

\section{Ratings are for $300 \times 10^{6} \mathrm{SCF} \mathrm{H}_{2} /$ day}

Figure 3.4: HTSE Water Boiler Loop (one of four) which also serves for decay heat removal 
The suggested arrangement of employing several self-powered water boiler loops to provide the steam needed by the HTSE cells is also quite synergistic with GFR decay heat removal requirements. The layout is shown in Figure 3.4. In normal operation and most shutdown scenarios, the turbine drives the $\mathrm{S}-\mathrm{CO}_{2}$ loop circulator, and generates excess electricity for plant or emergency system use. The reversible motor generator can also power the blower using on-site or off-site emergency electric power.

This arrangement has several advantageous features:

1. No changes are required in the main PCS loops used to provide electricity to the HTSE cells.

2. The water boiler (WB) loops eliminate the need for separate shutdown and emergency cooling loops.

3. The WB loops are always on, which increases the probability that they will be available for SCS/ECS service. (no fail-to-start sequences, and constant diagnostic signals.)

4. The WB loops are oversized for SCS/ECS service: they are designed to remove a total of about $8.8 \%$ of core full power ( $2.3 \%$ each), whereas only $2 \%$ is needed for decay heat removal. The required total water boiler energy rating is such that for their use in SCS/ECS service one can have four 100\% capable loops, versus the four $50 \%$ shutdown cooling system loops specified in the current all-electric design.

5. The use of four parallel trains is also desirable for their primary function of providing uninterrupted steam to the HTSE cells: one would like to have the ability to have one loop down for maintenance and also be able to accommodate random failure in another.

6. Oversizing also facilitates operation in a passive, natural-convection-only mode, in the event that full power not be available for WB loop circulators. The steam generators also have a generous inventory of water, which relaxes the time deadline for restoration of feedwater flow.

7. Steam in the SCS/ECS mode can be vented or used to power a small turbinegenerator for provision of emergency electric power (e.g., the reversible motor generator in Fig. 3.4). Steam storage accumulators can also serve both the HTSE plant and reactor emergency power turbines.

8. No adaptation of the PCS is required, reducing the probability that detrimental effects due to process changes occurs. This also limits the analysis required to determine complex effects and changing process conditions due to the extraction of $\mathrm{S}-\mathrm{CO}_{2}$ from the PCS directly.

This "fiddler crab" strategy of equipping a reactor with small stand-alone power conversion systems in parallel with the large PCS loops used to generate electricity is sufficiently attractive to suggest that it be employed even when not coupled to a HTSE plant. In this event the loops could each be smaller by a factor of two if $4 \times 50 \%$ protection is desired, and operated in hot standby mode.

\subsection{Estimate of Busbar Cost of Electricity}


Economic power generation is a major Gen-IV goal. This must be addressed on two levels: versus other Gen-IV fast reactors, and versus the new generation of LWRs contending for near term deployment in the U.S.

The analysis carried out under the aegis of the present project evolved to center on the following aspects.

(1) Plant capital cost.

Figure 3.5 illustrates the overall plant layout coupling the GFR reactor to supercritical $\mathrm{CO}_{2}$ Brayton power conversion units, which serves as the basis for all of our analyses. The arrangement shown fits inside a conventional $54 \mathrm{~m}$ inner-diameter PWR-type containment building. Figures 3.1 and 3.2 show additional views. Note the complete absence of a separate turbine building. This is possible because the $\mathrm{S}-\mathrm{CO}_{2} \mathrm{PCS}$ occupies a volume a factor of five smaller than a comparably rated Rankine steam power conversion system. The resulting large reduction in plant structural material can lead to a $15 \%$ reduction in capital cost, and approximately $10 \%$ lower busbar cost.

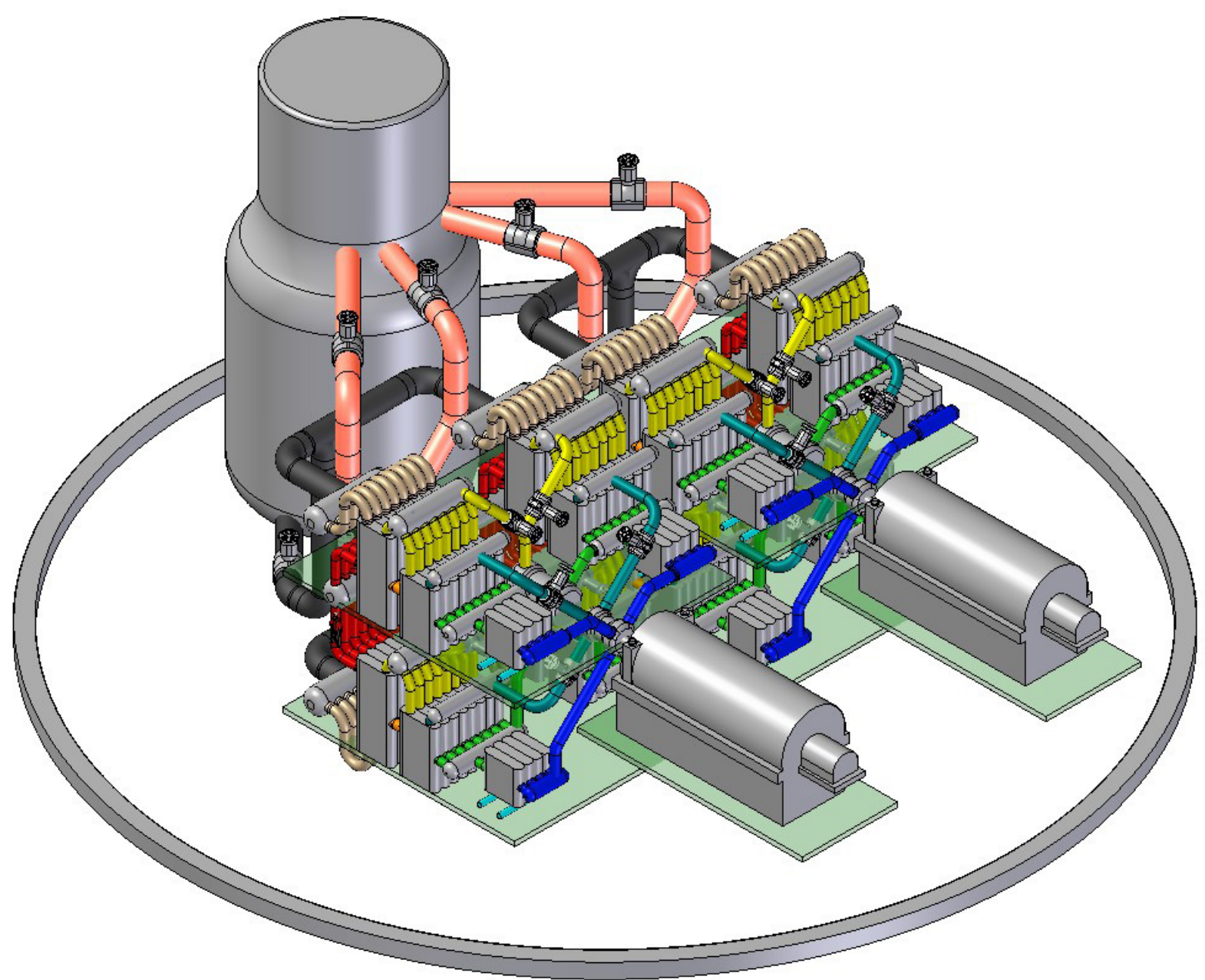

Figure 3.5: Arrangement of Reactor and Power Conversion Units 


\section{(2) PCS Thermodynamic Efficiency.}

The supercritical $\mathrm{CO}_{2}$ Brayton cycle can be used productively with any reactor having a coolant operating temperature above about $450^{\circ} \mathrm{C}$. Hence it is not suitable for LWR service. However, it could be employed (in an indirect cycle) with an SFR. Even so, the resulting turbine inlet temperature of about $500^{\circ} \mathrm{C}$ would result in a thermodynamic efficiency of on the order of $42 \%$ - much lower than the (consistently computed) $47 \%$ for the $650^{\circ} \mathrm{C}$ inlet temperature of the MIT GFR direct cycle. This factor alone gives a $15 \%$ lower busbar electricity cost in mills/kWhre versus the SFR, and $26 \%$ versus even the new MHI APWR with its claimed 38\% efficiency.

\section{(3) Fuel Cycle Cost.}

This is the principal cost penalty for the S-CO $\mathrm{CO}_{2}$ GFR. It is due to the low specific power caused by the goal of enhancing passive decay heat removal by natural convection, and by the high fuel volume fraction needed to achieve self sustainability (unity conversion ratio) with a blanket-free core. At a specific power of $21 \mathrm{~kW} / \mathrm{kgHM}$ (compared to Super Phenix at $95 \mathrm{~kW} / \mathrm{kgHM}$ ), the $\mathrm{S}-\mathrm{CO}_{2}$ GFR fuel cycle cost is 15 mills/kWhre: almost three times that of recent LWR experience. This, by itself, would offset about $15 \%$ of any busbar cost gains.

In view of the above findings it would be prudent to eventually have an architectengineering firm carry out a detailed plant cost estimate on one hand, and a parallel R\&D effort to increase core power density - up to at least the GA-GCFR 1970 value of $95 \mathrm{~kW} / \mathrm{kgHM}$.

\subsection{Chapter Summary, Discussion and Recommendations}

Meeting Gen-IV goals in the GFR context led to selection of several unique features (i.e. those not in evidence in other Gen-IV contenders):

- A supercritical $\mathrm{CO}_{2}$, direct cycle, Brayton power conversion system, to achieve high thermodynamic efficiency and reduce capital cost

- Vented tube-in-duct fuel assemblies to foster a sustainable conversion ratio and high burnup

- A prestressed cast iron reactor vessel (PCIV), and a robust PWR-type outer containment to bolster defense in depth

- Active decay heat removal, backed-up by significant passive (natural convection) capability to attain high reliability.

While these attributes were successful in meeting project objectives, the need to limit core power density and fuel specific power, made fuel cycle costs higher than desirable.

However, while probably not cost competitive with SFRs in its present incarnation, the GFR has sufficient room for improvement that this finding is not 
necessarily representative of what might be achieved given another round or two of design iterations. Chapter 4 outlines several possible modifications which appear worth evaluation.

3.5 References for Chapter 3: See task-wise bibliography in the report introduction especially Refs. No. 3.1-2, 3.2-2, and 3.3-3. 


\section{Chapter 4 Overall Conclusions and Potential Future Work}

\subsection{Introduction}

During the course of the present project a series of attributes for fast reactor performance have evolved under the Gen-IV/AFCI/GNEP programs against which GFR designs should be vetted in both absolute and relative terms. Table 4.1 lists some of the most important goals and an assessment of the extent to which they are satisfied by the version of the $\mathrm{S}-\mathrm{CO}_{2}$ GFR described in the preceding chapters of this report..

Table 4.1: Satisfaction of Gen-IV Attributes

\begin{tabular}{|c|c|c|}
\hline Attribute & $\begin{array}{c}\text { Pertinent S-CO} \\
\text { GFR Feature } \\
\end{array}$ & Comments \\
\hline \multirow[t]{3}{*}{ Safety } & $\begin{array}{l}\text { - Negative coolant void and } \\
\text { IFR-type reactivity feedback }\end{array}$ & - Assures post-LOCA shutdown \\
\hline & $\begin{array}{l}\text { - PCIV } \\
\text { mobust PWR-type contain- } \\
\text { ment }\end{array}$ & $\begin{array}{l}\text { - } \quad \text { Aircraft crash resistant } \\
\text { if post-LOCA P }>0.7 \mathrm{MPa}\end{array}$ \\
\hline & $\begin{array}{l}\text { - Active DHRs backed by } \\
\text { fully-capable passive mode } \\
\text { - Flow-levitated absorbers } \\
\text { - Fuel cell backup power } \\
\text { - "Fiddler-crab" DHRs }\end{array}$ & $\begin{array}{l}\text { - Eliminates unprotected LOF, LOCA } \\
\text { - Constant-on idle; no moving parts } \\
\text { - Small PCS loops in parallel with } \\
\text { main: hence self-powered }\end{array}$ \\
\hline Economics & - $\mathrm{S}-\mathrm{CO}_{2}$ direct cycle PCS & $\begin{array}{l}\text { Eliminates separate turbine } \\
\text { building; less steel and concrete } \\
\text { - High efficiency }\end{array}$ \\
\hline $\begin{array}{l}\text { Proliferation } \\
\text { Resistance }\end{array}$ & $\begin{array}{l}\text { - No U-238 blankets } \\
\text { - Long-lived battery core }\end{array}$ & $\begin{array}{l}\text { - } \quad \text { No weapons grade } \mathrm{Pu} \\
\text { - } \quad 17 \text { EFPY between refuelings }\end{array}$ \\
\hline Sustainability & - Core conversion ratio $\sim 1.0$ & $\begin{array}{l}\text { - Could evolve into blanketed core } \\
\text { with } \mathrm{CR}>1.0\end{array}$ \\
\hline Reliability & $\begin{array}{l}\text { - Simple, compact PCS } \\
\text { - Use of PCHE }\end{array}$ & $\begin{array}{l}\text { - } \quad \text { Can swap-out turbomachinery } \\
\text { - } \quad \text { Very rugged heat exchangers }\end{array}$ \\
\hline$\frac{\text { Waste }}{\text { Minimization }}$ & $\begin{array}{l}\text { - Burns TRU/MA } \\
\text { - Long-lived core }\end{array}$ & $\begin{array}{l}\text { - Comparable to other Gen-IV fast } \\
\text { reactors at same specific power } \\
(\mathrm{kw} / \mathrm{kg} \mathrm{HM})\end{array}$ \\
\hline
\end{tabular}

To help reach a judgement on the adequacy of the proposed design, and to identify promising areas for future design iterations, a series of tables have been 
prepared, showing $\mathrm{S}-\mathrm{CO}_{2}$ GFR features (Table 4.2) as they now stand, and how they compare to two other alternatives: the mainline CEA helium-cooled GFR (Table 4.3), and a generic SFR (Table 4.4). A brief discussion follows.

One should also note the results of a parallel NERI project which compared fast reactors cooled by liquid metals, liquid salt, and $\mathrm{CO}_{2}$, reported in:

N. E. Todreas, P. Hejzlar, "Flexible Conversion Ratio Fast Reactor Systems

Evaluation," Final Report, MIT-NFC-PR-101, June 2008.

Table 4.2: Status of GFR Plant Features as of August 2008

\begin{tabular}{|c|c|c|}
\hline Subsystem & Features & Comments \\
\hline \multicolumn{3}{|l|}{ Core } \\
\hline Fuel & $\mathrm{UO}_{2}+\mathrm{BeO}$ & LWR TRU fissile \pm MA \\
\hline Clad & ODS-MA956, or HT-9 & SiC a long range possibility \\
\hline Configuration & $\begin{array}{l}\text { tube-in-duct fuel assemblies, trefoil } \\
\text { or "hexnut" pellets, vented, orificed }\end{array}$ & $\begin{array}{l}\text { pin-type core as fallback is not } \\
\text { up to task }\end{array}$ \\
\hline Thermal-Hydraulics & $\begin{array}{l}\text { axial peaking factor } \leq 1.3 \\
\text { radial peaking factor } \leq 1.2 \\
\text { power density } \sim 85 \mathrm{~W} / \mathrm{cc}\end{array}$ & $\begin{array}{l}\text { Vary BeO fraction } \\
\text { to flatten power. } \\
\text { Lower than GA GCFR of } \\
1970 \text { 's @ } 235 \mathrm{~W} / \mathrm{cc} \\
\end{array}$ \\
\hline Burnup & $\geq 120 \mathrm{MWd} / \mathrm{kg}$ (avg) & $\begin{array}{l}\text { In single batch no-reshuffle } \\
\text { core, } 17 \text {-yr lifetime }\end{array}$ \\
\hline \multicolumn{3}{|l|}{ Safety Systems } \\
\hline Aux. Loops & $\begin{array}{l}\text { combined shutdown \& emergency, } \\
4 \times 50 \% \text { capable, active } \\
\text { forced convection; but passive } \\
\text { natural convection supplemented; } \\
\text { water boiler heat sink }\end{array}$ & $\begin{array}{l}\text { Based on RELAP parallel loop } \\
\text { calculations. For } \mathrm{P} \geq 0.7 \mathrm{MPa} \\
\text { natural convection alone may } \\
\text { suffice }\end{array}$ \\
\hline Emergency Power & Fuel cells to supplement diesels & $\begin{array}{l}\text { Projected to be more reliable } \\
\text { than diesels alone in long run }\end{array}$ \\
\hline \multicolumn{3}{|l|}{ Plant } \\
\hline $\begin{array}{l}\text { Power Conversion System } \\
\text { (PCS) }\end{array}$ & $\begin{array}{l}\text { supercritical } \mathrm{CO}_{2} \text { Brayton direct } \\
2 \times 600 \mathrm{MWe} \text { loops }=1200 \mathrm{MWe} \\
650^{\circ} \mathrm{C} \text { core exit/turbine inlet, } \\
\text { pressure: } 20 \mathrm{MPa}\end{array}$ & $\begin{array}{l}\text { AGRs in UK use } \mathrm{CO}_{2} \text { coolant } \\
\text { at } 4 \mathrm{MPa} \text { and } \\
\text { have } \mathrm{T} \sim 650^{\circ} \mathrm{C}\end{array}$ \\
\hline Reactor Vessel & $\begin{array}{l}\text { PCIV (prestressed cast iron reactor } \\
\text { vessel) }\end{array}$ & $\begin{array}{l}\text { Vessel houses loop isolation } \\
\text { and check valves plus shutdown } \\
\text { cooling heat exchangers }\end{array}$ \\
\hline Containment & $\begin{array}{l}\text { PWR type, steel liner reinforced } \\
\text { concrete } 0.7 \mathrm{MPa} \text { design capability } \\
70,000 \mathrm{~m}^{3} \text { free volume } \\
\text { filtered/vented }\end{array}$ & $\begin{array}{l}\text { Internally insulated and } \mathrm{CO}_{2} \\
\text { can be added to keep pressure } \\
\text { up to natural convection needs }\end{array}$ \\
\hline $\begin{array}{l}\mathrm{H}_{2} \text { production by steam } \\
\text { electrolysis } \\
\text { (optional) }\end{array}$ & $\begin{array}{l}\text { Separate water boiler loops (4) @ } \\
10 \% \text { of reactor power } \\
\text { Recuperation of } \mathrm{H}_{2} \& \mathrm{O}_{2} \text { heat allows } \\
\text { cell operation at } 850^{\circ} \mathrm{C}\end{array}$ & $\begin{array}{l}\text { Water boiler loops can also } \\
\text { serve for self-powered decay } \\
\text { heat removal }\end{array}$ \\
\hline
\end{tabular}




\subsubsection{Comparison of CEA and MIT GFR Designs}

As previously noted, the main-line Gen-IV GFR design is typified by the CEA helium cooled high-temperature version. The MIT version is something completely different in many respects. Table 4.3 contrasts key features. On a fundamental level, they have in common reliance on fuel designs of novel configuration and unproven material composition. As such, both will require an extensive development program with heavy reliance on in-pile irradiation testing. It could well be that the CEA core can be adapted to service in the MIT GFR; the reverse is not the case.

There is superficial similarity in that both versions employ Brayton cycle power conversion systems. However, CEA's is indirect, while MIT's is direct. We have previously evaluated an indirect cycle helium cooled GFR coupled to a Rankine PCS. However, this would reduce thermodynamic efficiency by about $7 \%$, which in turn increases the busbar cost of electricity by on the order of $15 \%$. Also, if an indirect cycle were employed, $\mathrm{CO}_{2}$ is recommended as the primary coolant since it oxidizes, hence immobilizes many fission products - a significant advantage for vented fuel. $\mathrm{CO}_{2}$ is also significantly better in natural convection, and could eliminate the first hour of active decay heat removal required in the CEA design post-LOCA. 
Table 4.3: Comparison of CEA and MIT GFR Designs

\begin{tabular}{|c|c|c|}
\hline Feature & CEA & MIT \\
\hline $\begin{array}{l}\text { Thermal power, MWth } \\
\text { Electrical power, MWe (eff.) } \\
\text { Power conversion system }\end{array}$ & $\begin{array}{l}2400 \\
1080(45 \%) \\
\text { Indirect Brayton } \\
\text { He primary } \\
\mathrm{He}+\mathrm{N}_{2} \mathrm{PCS}, \\
\text { steam bottoming } \\
3 \text { loops }\end{array}$ & $\begin{array}{l}2400 \\
1130(47 \%) \\
\text { Direct Brayton } \\
\text { Supercritical } \mathrm{CO}_{2} \\
2 \text { trains }\end{array}$ \\
\hline $\begin{array}{l}\text { Fuel Characteristics } \\
\text { Type of cercer } \\
\text { Configuration } \\
\text { \% TRU (at eq.) } \\
\text { Diluent/matrix } \\
\text { Vol. ratio, dil./fuel } \\
\text { Core heavy metal, kg } \\
\text { Core TRU, kg }\end{array}$ & $\begin{array}{l}\mathrm{UC} / \mathrm{SiC} \text { (het.) } \\
\text { Plate } \\
18.2 \\
\mathrm{SiC} \\
\sim 0.8 \\
60,500 \\
11,000\end{array}$ & $\begin{array}{l}\mathrm{UO}_{2} / \mathrm{BeO} \\
\mathrm{ODS} \text { tube-in-duct, vented } \\
15.8 \\
\mathrm{BeO} \\
\sim 0.4 \\
115,700 \\
18,300\end{array}$ \\
\hline $\begin{array}{l}\text { Core Characteristics } \\
\text { Power density, } \mathrm{kW} / 1 \\
\text { Specific power, } \mathrm{kW} / \mathrm{kg} \mathrm{HM} \\
\text { Burnup, MWd/MT } \\
\text { No. fuel assemblies } \\
\text { No. control rods } \\
\text { Core coolant } \\
\text { Coolant T, in } / \text { out }^{\circ} \mathrm{C} \\
\text { Pressure, } \mathrm{MPa} \\
\text { Vol. \% coolant }\end{array}$ & $\begin{array}{l}91.5 \\
39.7 \\
67,000 \\
246 \\
24 \\
\mathrm{He} \\
400 / 850 \\
7 \\
47.3\end{array}$ & $\begin{array}{l}85.4 \\
20.7 \\
140,000 \\
372 \\
19 \\
\mathrm{CO}_{2} \\
485 / 650 \\
20 \\
27\end{array}$ \\
\hline $\begin{array}{l}\text { Decay heat removal } \\
\text { Loops X capability } \\
\text { post-LOCA: }\end{array}$ & $\begin{array}{l}3 \times 100 \% \\
\text { Active for } 24 \mathrm{hrs;} \\
\text { passive thereafter (or } \\
\text { otherwise), can be boosted } \\
\text { by } \mathrm{N}_{2} \text { accumulators }\end{array}$ & $\begin{array}{l}4 \times 50 \% \\
\text { Active with passive } \\
\text { backup at all times }\end{array}$ \\
\hline $\begin{array}{l}\text { Containment } \\
\text { Type: }\end{array}$ & $\begin{array}{l}\text { "close" (proximate, guard) } \\
\text { @ } 1 \mathrm{MPa}\end{array}$ & $\begin{array}{l}\text { PWR type } \\
\text { @ } 0.7 \mathrm{MPa}\end{array}$ \\
\hline
\end{tabular}

\subsubsection{Comparison of S- $\mathrm{CO}_{2}$ GFR with Sodium-Cooled Fast Reactor}

Table 4.4 compares key features of the subject GFR to a generic sodium-cooled fast reactor (SFR), which concept has emerged as the consensus choice worldwide for 
future attention. As evident, the major shortcomings of the GFR are the reduced rate at which it consumes transuranics/minor actinides, and the difficulty of relying only on natural convection for passive-mode decay heat removal. These limitations relate directly to the need for, and consequences of, lower core power density.

Table 4.4: Comparison of S-CO${ }_{2}$ GFR with SFR

\begin{tabular}{|c|c|c|}
\hline Aspect & $\mathrm{S}-\mathrm{CO}_{2}$ GFR & SFR \\
\hline $\begin{array}{l}\frac{\text { Core }}{\text { Power Density, kW/1 }} \\
\text { Fuel Materials } \\
\text { Burnup (HM, TRU, MA) } \\
\text { Conversion (Breeding) Ratio }\end{array}$ & $\begin{array}{l}\text { Moderate }(\sim 100) \\
\mathrm{UO}_{2} \\
\text { Slower rate } \\
\text { High }\end{array}$ & $\begin{array}{l}\text { High }(\sim 300) \\
\mathrm{UO}_{2}, \mathrm{UC}, \mathrm{UN}, \mathrm{UZr} \\
\text { Comparable MWd/MT } \\
\text { but faster rate } \\
\text { A bit lower }\end{array}$ \\
\hline $\begin{array}{l}\text { Primary System } \\
\text { Pressure } \\
\text { Power Consumed to circulate } \\
\text { coolant } \\
\text { Natural Convection (hence } \\
\text { "passivity") } \\
\text { Chemical Reactivity of Coolant } \\
\text { Inspectability }\end{array}$ & $\begin{array}{l}\text { High: } 20 \mathrm{MPa} \\
\text { High } \\
\text { Weak } \\
\text { Low } \\
\text { Transparent coolant }\end{array}$ & $\begin{array}{l}\text { Low: } 0.3 \mathrm{MPa} \\
\text { Low } \\
\text { Strong } \\
\text { High (with air, } \mathrm{H}_{2} \mathrm{O} \text { ) } \\
\text { Opaque coolant }\end{array}$ \\
\hline $\begin{array}{l}\text { Power Conversion } \\
\text { Cycles: } \\
\text { Efficiency: } \\
\text { BOP cost: }\end{array}$ & $\begin{array}{l}\text { Direct Brayton } \\
\text { Indirect Brayton } \\
\text { Indirect Rankine } \\
\text { Higher if direct } \\
\text { Lower if direct }\end{array}$ & $\begin{array}{l}\text {-- } \\
\text { Indirect* Brayton } \\
\text { Indirect* Rankine } \\
\text { Indirect is comparable } \\
\text { Indirect is comparable } \\
* \text { (plus intermediate loop) }\end{array}$ \\
\hline$\underline{\text { Containment }}$ & EPR type: $\sim 7$ atm & $\begin{array}{l}\text { Lower Pressure: } \\
\leq 2 \mathrm{~atm}\end{array}$ \\
\hline Upside Potential & $\begin{array}{l}\text { Higher temperature, } \\
\text { efficiency, breeding } \\
\text { ratio possible }\end{array}$ & Mature technology \\
\hline Experience Base & $\begin{array}{l}\text { Limited, none built } \\
\text { demo unit needed }\end{array}$ & $\begin{array}{l}\text { Widespread, many built } \\
\text { can forego demo }\end{array}$ \\
\hline
\end{tabular}

These comparisons raise a number of interesting questions on design alternatives which were considered in the past but rejected, and newer ones which have emerged as worthy of future evaluation in the course of our final internal review. Both categories are addressed in the next section of this chapter.

\subsection{Design Alternatives}


Table 4.5 lists the major design features that emerged in the course of our effort to design a version of the GFR which could best meet Gen IV Program objectives. Since most would require significant up-front $R \& D$, fall-back alternatives and their consequences are also shown. All have been constrained by the common requirement of not exceeding $650^{\circ} \mathrm{C}$ as the coolant outlet temperature. One could argue that this is not an insurmountable limit, in view of the fact that both the CEA He-cooled GFR and the ORNL/MIT liquid salt cooled fast reactor aim at $850^{\circ}$ coolant outlet temperatures. It is also encouraging to note that Carleton University, which has a significant program on $\mathrm{CO}_{2}$ power cycle development, has chosen $750^{\circ} \mathrm{C}$ as their reference turbine inlet temperature (4-1). However, since the supercritical $\mathrm{CO}_{2}$ power conversion system, with its attendant $20 \mathrm{MPa}$ pressure, is the defining feature of the present design, and since steel strength falls off rapidly at higher temperatures, the $650^{\circ}$ limit is a prudent one.

Table 4.5: Unorthodox features of $\mathrm{S}-\mathrm{CO}_{2}$ GFR design, and fall-back alternatives

\begin{tabular}{|c|c|c|}
\hline Feature & Alternatives & Comments \\
\hline \multirow{2}{*}{$\begin{array}{l}\text { Supercritical } \mathrm{CO}_{2} \\
\text { Brayton Power } \\
\text { Conversion } \\
\text { Cycle, Direct }\end{array}$} & $\begin{array}{l}\text { Indirect Cycle, } \\
\text { Steam Rankine PCS }\end{array}$ & $\begin{array}{l}\text { - Can employ He Primary Coolant } \\
\text { - Loss of Efficiency } \\
\text { - Higher Capital Cost }\end{array}$ \\
\hline & $\begin{array}{l}\text { Indirect Cycle } \\
\text { S-CO2 Brayton PCS }\end{array}$ & $\begin{array}{l}\text { - Efficiency penalty due to lower T } \\
\text { \& primary circulators }\end{array}$ \\
\hline \multirow[t]{2}{*}{$\begin{array}{l}\text { Vented Tube-in-Duct } \\
\text { Fuel Assembly } \\
\text { BeO Diluent }\end{array}$} & $\begin{array}{l}\text { CEA Cercer } \\
\text { GFR Fuel } \\
\text { SiC flow tubes }\end{array}$ & $\begin{array}{l}\text { - Fuel runs } 200^{\circ} \mathrm{C} \text { cooler than CEA } \\
\text { - He version of GFR } \\
\text { - Venting not needed } \\
\text { - Still requires significant R\&D }\end{array}$ \\
\hline & $\begin{array}{l}\text { GA pin fuel } \\
\text { Circa } 1970\end{array}$ & $\begin{array}{l}\text { - Indirect cycle required to reduce } \\
\text { primary coolant pressure } \\
\text { - Venting still needed }\end{array}$ \\
\hline \multirow[t]{2}{*}{$\begin{array}{l}\text { Prestressed cast iron } \\
\text { reactor vessel (PCIV) }\end{array}$} & $\begin{array}{l}\text { Prestressed concrete } \\
\text { reactor vessel }\end{array}$ & $\begin{array}{l}\text { Reduced pressure }(<<20 \mathrm{MPa}) \text {, } \\
\text { hence indirect cycle }\end{array}$ \\
\hline & Steel vessel & $\begin{array}{l}\text { - Reduced plant rating to fit size of } \\
\text { state of art vessels }\end{array}$ \\
\hline $\begin{array}{l}\text { Advanced PWR } \\
\text { (EPR) type } \\
\text { containment }\end{array}$ & $\begin{array}{l}\text { Low pressure } \\
\text { filtered, vented }\end{array}$ & $\begin{array}{l}\text { - } \text { Active decay heat removal } \\
\text { essential } \\
\text { - } \text { Cost reduced }\end{array}$ \\
\hline
\end{tabular}

Note that several of the alternatives involve shifting to an indirect cycle. The resulting temperature drop of 20 to $50^{\circ}$ across intermediate heat exchangers, and primary circulator power consumption (e.g. $50 \mathrm{MW}$ ), lead to reduced thermodynamic efficiency, hence higher busbar costs in mills/kWhre. Nevertheless this may merit re-examination based on other considerations. 


\subsubsection{Indirect Cycle Considerations}

Going to an indirect cycle - a stratagem employed for the "Breed-and-Burn" GFR evaluated at MIT in a prior NERI project - opens up other variations: for example, use of carbide or nitride fuel forms. This was, in fact, taken advantage of by Yarsky et al., as documented in Ref. 4-2. These options have, however, been narrowed by two considerations. Carbide fuel, once the centerpiece of the fast reactor program in India, has just recently been abandoned in favor of oxide, because of the propensity for chipping and powdering of UC (4-3). While nitride fuel is specified for the latest Russian fast reactor design, $\mathrm{BN}-1800$ (4-4), the issue still remains of the cost of isotopic enrichment in $\mathrm{N}-15$, which is only $0.37 \%$ of natural nitrogen. Thus oxide fuel remains the preferred candidate, since the zirconium alloy fuel favored for many sodium-cooled fast reactor designs limits coolant outlet temperatures to considerably below $550^{\circ} \mathrm{C}$ (and probably $500^{\circ} \mathrm{C}$ for gas coolants).

Reactor physics and thermal-hydraulic consequences of substituting $\mathrm{CO}_{2}$ for $\mathrm{He}$ do not appear to be significant. For example, Yarsky (4-2) has compared GFR cores for He at $8 \mathrm{MPa}$ and $\mathrm{CO}_{2}$ at $20 \mathrm{MPa}$ and found that the latter has a slight reactivity penalty $(\Delta \rho=0.009)$, but a small conversion ratio gain $(\Delta \mathrm{CR} \sim 0.01)$. Both differences are essentially negligible, or easily accommodated. Similarly, Lyall has compared $\mathrm{CO}_{2}$ and $\mathrm{He}$ as reactor coolants, with similar conclusions as to interchangeability (4-5). It is true, however, that $\mathrm{CO}_{2}$ is superior to $\mathrm{He}$ in natural convection mode, as might dominate during decay heat removal (4-6).

\subsubsection{Use of Non-Vented Fuel}

The use of vented tube-in-duct fuel is a major unique feature of the MIT version of the GFR. Its qualification would require a long and expensive program, not likely to be shared as R\&D for other Gen-IV concepts. In addition, venting creates the need to develop means to cope with higher radionuclide (mainly $\mathrm{Kr}-85$ ) concentrations in reactor primary coolant and/or purification systems. Thus an alternative backup approach should be identified. Metal clad sealed pins are ruled out due to high operating temperature and differential pressure. Thus the most promising stand-in would appear to be the cercer fuel being developed, principally in France, for the mainline helium cooled Gen-IV GFR.

Reference (4-7) contains an extensive up-to-date description of the CEA GFR and the Experimental Technology Development Reactor (ETDR) proposed to validate key features of this technology. In these reactors helium is the coolant at $7 \mathrm{MPa}$ and an outlet temperature of $850^{\circ} \mathrm{C}$. However the ETDR initial core will start at $650^{\circ} \mathrm{C}$, which is the value specified for the MIT $\mathrm{S}-\mathrm{CO}_{2}$ version. $\mathrm{SiC}$ is the leading candidate for use as the fuel matrix. 
Reducing service temperature by $200^{\circ} \mathrm{C}$ should considerably improve CEA-type fuel internal robustness. Thus the issue of principal remaining concern is the chemical compatibility of $\mathrm{SiC}$ and $\mathrm{CO}_{2}$.

Reference (4-8) reports corrosion tests on $\mathrm{SiC}$ in $\mathrm{CO}_{2}$ at temperatures much higher than of current interest $\left(1200-1400^{\circ} \mathrm{C}\right)$, albeit for limited duration $(<500 \mathrm{hrs})$. Measured corrosion rates were very small, and negligible compared to that in oxygen. Thus we may also draw some inferences regarding compatibility from air ingress studies for HTGRs, which employ $\mathrm{SiC}$ coated fuel particles, and where $\mathrm{O}_{2}, \mathrm{CO}$ and $\mathrm{CO}_{2}$ are all present.

\subsubsection{Reactor Vessel Selection (4-9)}

Because of the high pressure $(20 \mathrm{MPa})$ and relatively large core volume of the MIT S-CO $\mathrm{CO}_{2} \mathrm{GFR}$, a prestressed cast iron vessel (PCIV) is specified. This technology was developed in Germany, and tested at a moderate scale, but has never been used in actual reactor service. Designers have since proposed use in several conceptual designs of large reactors: HTGR, BWR and PWR. Since the last listed has an operating pressure of 15 $\mathrm{MPa}$, it is assumed that extrapolation to $20 \mathrm{MPa}$ is possible. While PCRV technology is more advanced and has been employed for thermal spectrum GCRs, there is less confidence that $20 \mathrm{MPa}$ is practicable. Moreover, the iron of the PCIV is more tolerant of high temperature than the concrete of the PCRV.

Steel vessels were given strong consideration, but passed over because of the large diameter needed for the GFR. Since the power density is about the same as a PWR $(100 \mathrm{~kW} / \mathrm{l})$, this limitation may not be self-evident. However, the PWR core has a diameter of about $3.4 \mathrm{~m}$ and a height-to-diameter ratio of approximately 1:1 (the minimum leakage value), while the GFR core is somewhat "pancaked" to boost leakage, hence reduce positive coolant void reactivity $(\mathrm{H}=1.54 \mathrm{~m}, \mathrm{D}=4.81 \mathrm{~m})$ and to reduce pressure drop, thereby enhancing natural circulation. Furthermore, fast reactors are inherently endowed with a much higher fast neutron flux. This requires more radial shielding to protect in-vessel structures and the reactor vessel itself.

It may be worth revisiting the case for steel vessels if the H:D ratio is increased and more exotic radial shield materials are employed. The coolant voiding reactivity can be offset by the use of flow-levitated absorbers in the inner reflector row of assemblies, subject to confirmation that their insertion is sufficiently rapid.

Also worth noting is that core volume could be reduced by a factor of two if power density were to be increased to values more typical of the GFR designs of the 1970 time frame. This would, of course, rule out reliance to any great extent on natural convection, hence passive, decay heat removal. This can probably be validated by PRA analyses, given sufficiently diverse, redundant, and reliable active systems, but would suffer, perhaps irretrievably, from the loss of psychological cachet associated with passive systems. 
Reactors having conventional PWR-size steel pressure vessels could be built in modules of 300-600 MWe. The diseconomies of smaller scale will not be as severe for the $\mathrm{S}-\mathrm{CO}_{2} \mathrm{PCS}$, which is, in any event, limited to this rating range by the available size of high pressure ducts and valves. and the difficulty of interfacing large ductwork with small turbomachinery and PCHE.

Finally, another factor of recent concern may favor use of both the PCIV and a robust containment to provide defense-in-depth even in the event of intentional aircraft crashes. Depending on how this future licensing issue plays out, the SFR advantage of having a much lower containment design pressure may not pertain.

\subsection{Future Research Needs for the S-CO $\mathrm{CO}_{2}$ GFR}

The most acute need is for experimental verification of the performance characteristics of vented fuel: specifically the efficacy of vent path diffusive holdup, immobilization of most otherwise-volatile species by reaction with $\mathrm{CO}_{2}$ and its radiolysis products, deposition on ex-core surfaces, and high efficiency purification of $\mathrm{CO}_{2}$ coolant. This could be accomplished, for example, using an in-pile loop at the MIT Research Reactor. Several similar loops have been operated in the past to study PWR and BWR water chemistry, corrosion, and activity transport and deposition. Work was recently completed on irradiation of annular $\mathrm{UO}_{2}$ fuel pellets for advanced reactor applications. A gas-cooled loop capable of testing materials up to $1600^{\circ} \mathrm{C}$ is currently in service. Finally, an in-pile loop to test corrosion by, and radiolysis of, $\mathrm{CO}_{2}$ was designed in 2004, but construction was not completed due to sponsor program re-direction. Such a program would cost several hundred thousand dollars per year for several years.

A second major feature of the MIT GFR, the $\mathrm{S}-\mathrm{CO}_{2}$ power conversion system, is already the subject of a small scale test and demonstration program at Sandia National Laboratory, which should be more than adequate for resolution of issues applicable to the GFR. Concurrent programs in Korea, Japan, and at Carleton University in Canada, should provide confirmatory input.

In the much longer term, a prudent approach would be to build a small test reactor, much as the French have elected to do in the helium cooled 50 MWth Experimental Technology Development Reactor (EDTR), currently proposed for startup in 2015.

Another new initiative is the potential use of the CEA UC/SiC cercer core in $\mathrm{S}$ $\mathrm{CO}_{2}$ instead of He. Direct substitution at $650^{\circ} \mathrm{C}$ outlet temperature is $200^{\circ}$ below the $\mathrm{He}$ service value, hence should be much less demanding. If practicable, this would confer the significant benefit of not requiring fuel venting. A net thermodynamic efficiency of $47 \%$ would still be achievable. If corrosion resistance at $850^{\circ} \mathrm{C}$ were tolerable, then $54 \%$ efficiency is predicted. This would reduce the busbar cost of energy by about $15 \%$. This should be compared to the CEA reference cycle efficiency of $47 \%$. Realization of this 
potentially large improvement depends upon showing adequate corrosion resistance of both the core and the gas turbine plant. Gas-fired gas turbine inlet temperatures are now in excess of $1100^{\circ} \mathrm{C}$, for combustion gas mixtures of $\mathrm{CO}_{2}$ and $\mathrm{H}_{2} \mathrm{O}$ vapor, which are more corrosive than dry $\mathrm{CO}_{2}$. Hence it appears likely that the BOP can readily accommodate $850^{\circ} \mathrm{C}$. Thus only the corrosion resistance of $\mathrm{SiC}$ and $\mathrm{UC}$ are at issue. While $\mathrm{CO}_{2}$ oxidizes $\mathrm{SiC}$ to $\mathrm{SiO}_{2}$, there is some data supporting the formation of a protective surface layer. Reference (4-10) describes the results of $\mathrm{SiC}$ corrosion tests in static air for temperatures in the range $1200-1500^{\circ} \mathrm{C}$ for up to $2000 \mathrm{hrs}$ exposure. Trivial weight gains on the order of $0.1 \%$ are reported. Considering that $\mathrm{O}_{2}$ is more corrosive than $\mathrm{CO}_{2}$, and the temperatures are much higher than we require, the outlook appears promising. Again, contemporary corrosion studies in Korea, Japan and at Carleton University should be monitored. Note, however, that none are carried out in the presence of $\mathrm{CO}_{2}$ radiolysis.

Reaction of $\mathrm{CO}_{2}$ with UC in defected fuel appears to be a serious problem. If UC compacts are employed, as in some CEA versions, a CVD coating of SiC may suffice. This is clearly an area requiring experimental investigation.

A third initiative would be to rehabilitate the concept of using uranium breeding blankets. A conversion ratio greater than unity would allow fast reactors to operate autonomously in a demand growth scenario. The most promising approach appears to be addition of moderator to the blanket U-238 so that bred-in plutonium isotopes are at least as weapons unattractive as that from LWRs. This has recently been suggested by Japanese investigators (4-11). Since epithermal capture to fission ratios of $\mathrm{Pu}-239$ are higher than for either fast or thermal neutrons, this approach should be feasible, provided that undesirable side effects are tolerable. Another advantage of blankets is that the core can be opened up (coolant volume fraction increased), which permits higher power density, and hence lower fuel cycle unit costs in mills/kWhre.

Finally, two generic advances identified during the course of this project deserve evaluation for other reactor types: recuperation of heat from product $\mathrm{H}_{2}$ and $\mathrm{O}_{2}$ in high temperature steam electrolysis to allow coupling to reactors which cannot operate at $850^{\circ} \mathrm{C}$; and the use of fuel cells for on-site emergency power generation in place of, or in addition to, diesel generators.

\subsection{References for Chapter 4}

(4-1) Gas Turbines for Low-Emission Power Generation: Final Report, Dept. of Mechanical and Aerospace Eng., Carleton University, Ottawa, Canada, April 2008

(4-2) P. Yarsky, M. J. Driscoll, P. Hejzlar, "Integrated Design of a Breed and Burn Gas-Cooled Fast Reactor Core,” MIT-ANP-TR-107, Sept. 2005

(4-3) Private Communication, Prof. N. E. Todreas (MIT), following visit to India, Jan. 2008

(4-4) "BN-1800: A Next Generation Fast Breeder," Nuclear Engineering International, Vol. 49, No. 599, June 2004 
(4-5) H. G. Lyall, "A Comparison of $\mathrm{CO}_{2}$ and Helium as Reactor Coolant," GasCooled Reactors Today, Proceedings, Vol. 3, BNES London (1982)

(4-6) W. Williams et al., "Analysis of a Convection Loop for GFR Post-Loca Decay Heat Removal from a Block-Type Core," MIT-ANP-TR-095, March 2003

(4-7) “Gas-Cooled Nuclear Reactors,” CEA/DEN Monograph, Saclay (2006)

(4-8) D. C. Larson et al., "Ceramic Materials for Advanced Heat Engines: Technical and Economic Evaluation," Noyes (1985)

(4-9) L. B. Fishkin, "Prestressed Cast Iron Vessel (PCIV) Use for Gen-IV GFR Applications," MIT-GFR-006, April 2004

(4-10) E. J. Opila, Q. N. Nguyen, "Oxidation of Chemically-Vapor-Deposited Silicon Carbide in Carbon Dioxide,” J. Am. Ceram. Soc., 81 (7), 1949-52 (1998)

(4-11) T. Yokoyama et al., "Local-Spectrum-Modified Fast Reactor Cores with Hydrides," Proc. of ICAPP '06, Reno, June 4-8, 2006 


\section{Appendix A Historical Perspective}

The modern era of work by MIT on gas cooled fast reactors began in Fall 2001 as an LDRD project supported by INL. Results of the three year project were reported in:

M.J. Driscoll, P. Hejzlar, “An Innovative Gas-Cooled Fast Reactor,” MIT-GFR021, Sept. 30, 2004

Most of the basic features introduced in this first generation project were carried forward into a coordinated set of second generation projects, as mapped out in Fig. A.1, from the above reference. These in turn led to a third generation, of which the project culminated by this report was the centerpiece. Topical reports and papers published by MIT under all of these projects are listed in the cumulative bibliography compiled in Appendix B. However, it should be noted that coverage is necessarily incomplete for the wider scope of the International Nuclear Energy Research Initiative (INERI) projects in which MIT participated in the lesser role of collaborator. In particular, one is referred to:

Project No. 2001-002-F, "Development of Generation IV Advanced Gas-Cooled Reactors with Hardened/Fast Neutron Spectrum"; U.S. PI T. Y. C. Wei (ANL) and Project No. 2004-010-F, "PRA-Aided Design of Advanced Reactors with an Application to GFR Safety-Related Systems"; U.S. PIs (in succession): K. Weaver (INL), T. Y. C. Wei (ANL), G. Apostolakis (MIT) 
First
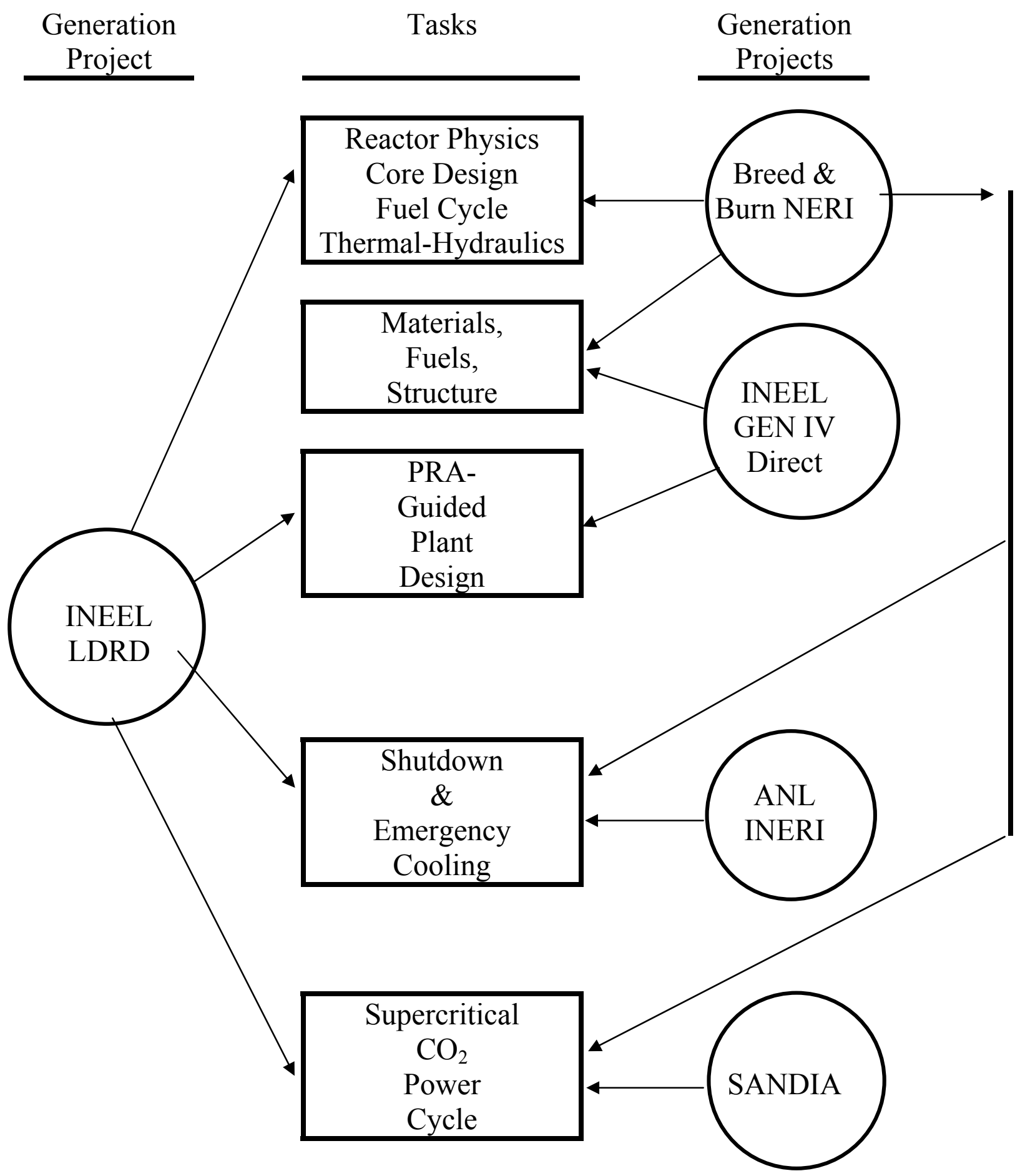

Fig. A.1 Family Tree of GFR Projects at MIT as of Sept. 2004

The annual DOE summary reports for these INERI projects follow, to provide a fuller perspective. Since the INERI effort at MIT was eventually subsumed into the 
present MIT NERI project (No. 05-044) as a designated subtask, the applicable DOE summary reports for this project are also included.

Finally, attention is called to another NERI project at MIT, contemporaneous with the present one:

Project No.: 06-040, "Flexible Conversion Ratio Fast Reactor Systems Evaluation," PIs: N. E. Todreas, P. Hejzlar

This project focuses main on lead and liquid salt cooled fast reactors, but at a secondary level also compares their performance to sodium and gas-cooled units. 


\section{International Nuclear Energy Research Initiative}

Development of Generation IV Advanced Gas-Cooled Reactors with Hardened/Fast Neutron Spectrum

Primary Investigator (U.S.): TYC Wei, Argonne

National Laboratory

Primary Investigator (France): J. Rouault DEN/DER/SERI CEA Cadarache

Collaborators: Brookhaven National Laboratory; General Atomics; Massachusetts Institute of Technology; Oak Ridge National Laboratory; Framatome - ANP (Fra-ANP), Lyon
Project Number: 2001-002-F

Project Start Date: January 31, 2002

Project End Date: December 30, 2004

\section{Research Objective}

The project objective is to design a Gas Fast neutron Reactor (GFR) with a high level of safety and full recycling of the actinides that have also to be highly proliferation resistant and attractive in terms of economics. This three-year project started March 2002.

\section{Research Progress}

Collaboration is already highly effective between the two sides. After information exchange through documents and direct contacts, work started on the definition of design goals and criteria for the GFR and on an R\&D plan focusing on the important issues for the design (fuel, high temperature structural materials, safety, etc.). Major agreed design goals are to focus on 300 to 1000 MWe cores with power densities in the range 50 to $100 \mathrm{MW} / \mathrm{m}^{3}$. For sustainability and nonproliferation reasons, self-generating cores will be considered with integral homogeneous recycling of all actinides present in spent fuels. The GFR Design Goals and Criteria document GFR 001, Rev 0 was issued. The draft "GFR Re D Plan" GFR 002, Rev 0 has also been completed.

Exploratory design studies whose objective is to select some promising set of design options for plant trade studies indicate the necessity to work with a high heavy metal content within the core (volumetric fraction of about $25 \%$ ). These studies also show that dense fuels like carbides or nitrides help to achieve the high actinide core content required to reach self-generation. Dispersed fuels, in which the actinide compound volumetric fraction can reach 50 to $70 \%$, with the rest being occupied by an inert material (matrix) playing the role of barrier against fission product (FP) release, look to be interesting candidates in association with block or plate type assemblies. A potential plate assembly configuration is shown in Figure 1. Pin concepts with a solid solution fuel in the form of pellets are not to be excluded even if they refer to a different logic with respect to FPs retention. Particle core design is tight but some margins could be recovered by considering large cores of $1000 \mathrm{MWe}$.

Assessment of the various possible means to extract heat from the core during accident conditions, in particular in case of depressurization, has been made. It shows that, depending on the power density level, the safety strategy must rely on diversified means: if the long-term heat removal will have to rely on natural convection, at least of He primary coolant, the beginning of the transient will have to use semipassive systems like heavy gas injection in the core. Passive systems like heat pipes or in-core heat exchangers have also been studied. Forced convection, even at several percent of nominal flow with circulators of very limited power, is a very efficient means of core cooling.

\section{Planned Activities}

Areas of future work are the important points of feasibility of the design of gas/gas top-mounted heat exchangers and containments able to ensure backup pressures for the time needed. This will be scoped for the safety strategy definition. 
Significant technical results have now been obtained to be in a position to select several design options for trade studies. The interesting point is that the promising concepts are identified within the agreed domain for sustainability and safety goals. Selection of the various design options for the trade studies starting with the second year of the project will be accomplished.

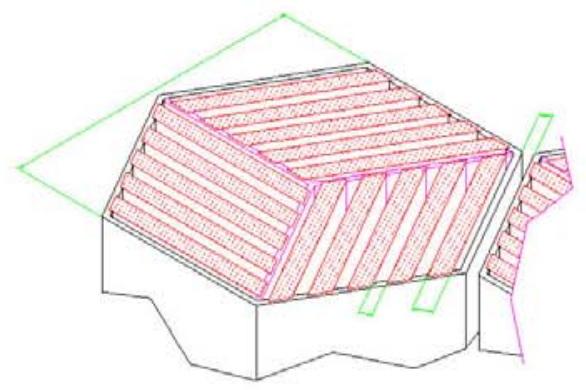

Figure 1. Sobeme of the Canor Plate Assembly 


\section{International Nuclear Energy Research Initiative}

Development of Generation IY Advan ced Gas-Cooled Reactors with Hardened/Fast Neutron Spectrum

Principal Investigator (U.S.): TYC'Miei, Argorne National Laboratony

Principal Investigator (France): J. Rouault, DEN/DER/SERI EACAdarache

Collaborators: Brookhaven Nationa Laboratory; General Atomic; Mas sachusetts Institute of Tectnology; OakRidge National Laboratory; Framatome - ANP (Fra-ANP), Lyon
Project Number: 2001-002 F

Project Start Date: January 2002

Project End Date: Sepkember 2005

Reporting Period: atober 2002 - September 2003

\section{Research Objective}

The projed objective is to design a Gas Fast Neutron Reactor (GR) with a high level of safery and ful recycling of the actinides, which also must be highly proliferation resistant and at tradive in terms of economics.

\section{Research Progress}

Collaboration has been very effective, and three progress meetings have been held. Work on the definition of de sign goals and oriteria for the GR has been finalized and a rese arch and devel coment (R\&D) plan focusing on the import ank is sues for the design (fuel, high-temperature structural materials, s afety, etc.) has been issued. It is now the basis for the Generation IV GRR R\&D plan defirition. Gollaboration be tweenthe twocountries has resulted in the completion and release of the topical report GRR 002, Rev. 0 "GFR R\&D Plan." This met the miles tone for producing a 10 -ye ar GR development plan, which can be used inthe Generation IV program effort on the GR.

The first ye ar of the project ended on Febnuary 28, 2003. Work on the first two quarters in FY 2003 foossed onmeeting the milestones and de liverables of the project for the first year. This work completed the exploratony stage of the collabor ative project, where se veral new and imowative concepts for fast reactor core designs and corres ponding passive decay heat removal stiemes were explored and integrated. Implications for the primarys system and balance of plant layout were also inve stigated. Techrical exchanges of ideas regarding the devel coment of the require dimowati ve fuel forms oontinued between $F$ and, $\mathrm{NL}$. In add tion, inke raction was st arted withDOE's Advancedfuel Cycle Iritiative ( $\mathrm{AFC}$ )/Generation IV progams. Similarinkeractions began with the Generation IV prog am in the are a of structural materials.

In summany, Task 3 (Explorat ory Core/Fuel Forms/ Prim ary Systems Concepts) was completed this year. Subtask 3.1 on core designs refined a number of the core neutronic design caloulations performed during the last ye ar andproduced report GR 004," "Gas-Coded Fast Reactor Core Desigrs." Subtask 3.2 on core-decay heat-pas sive safety complet ed caloulations onpassive de cay heat removal conoepts for blockiplate based cores, pebtle/particle based cores, andpintased cores. A combination of natural convedion and inzore heat extangers is being proposed. The implications for conka irment resporse were examined. In the case of the pebtle bed core, a desigrrspecific core dump system was explored. This effort produced the following deliverable reports:

1. GR006 "Passi ve Decay He at Re moval in Pin Based Gores"

2. GFR007 "Cold Finger IrrCore Decay Heat Removal for Petble Bed GR Designs"

3. GR 008 "Passive Deca y Heat Remoual in Partide/ Pebble Based Core"

4. GRR009 "Analys is and Recommendationfor Decay Heat Removal from Gas Cooled Fast Reactor"

5. MIT-ANP-TR-095 "inalys is of a Convedion Loop for GRR Post-LOCA.Decay Heat Removal."

In addition, a toptevel document on s afety approach and goals was produced entitled GR 005 "GasGooled Fast Re act or Safety Approat, General Recommendations." 
The investigation of the implications of the safety approach on passive decay heat removal produced the following reports:

1. GFR003, "High Temperature Vessel Structures"

2. GFR010, "Feasibility Study on the Application of a Leak Before Break Procedure in Metallic Vessels of a GFR."

Finally, regarding the possibility of an alternative primary coolant, supercritical $\mathrm{CO}_{2}$ as a backup to the reference primary coolant helium produced the deliverable entitled MIT-ANP-TR-090, "CO 2 Brayton Cycle Design and Optimization."

Preparations were made toward the end of the first year for the second CEA Cadarache-France/Argonne National Laboratory (ANL)-U.S. technical workshop on the I-NERI GFR project. This workshop was held at ANL March 31April 3, 2003, to present and discuss the results of the work during the first year. Based on this discussion, down selection of innovative core/reactor design concepts and safety approaches occurred. These selected concepts now form the basis of the concept trade studies that are being carried out in the second year of the I-NERI project. Agreement was reached between France and the U.S. project staff on the collaborative work scope to implement the trade studies in the second year.

It was agreed that the major design goals would focus on 300 to $1000 \mathrm{MWe}$ cores with power densities in the range 50 to $100 \mathrm{MW} / \mathrm{m}^{3}$. For sustainability and nonproliferation reasons, self-generating cores will be considered with integral homogeneous recycling of all actinides present in spent fuels.

\section{Current important common conclusions are as follows:}

- Design Goals and Criteria: an agreement was reached on the major goals. Discussions took place on the necessity of a criterion on the Pu inventory per GWe. It was agreed that this would be necessary to easily deploy the GFR. A value not exceeding $15 \mathrm{t}$ / GWe was found to be a necessity at least for situations in France and the U.S. The question concerning the origin of the criteria on the containment pressure resistance (value and time required) remains to be assessed.

- Fuels and Materials: recommendations for the ongoing detailed studies were made on both the design and material choices. Detailed comparison of carbide and nitride fuels concludes that these two remain serious candidates and that only ongoing $R \& D$ could bring new elements for focusing the choice. Nevertheless, current French evaluations stressed the difficulties of ${ }^{15} \mathrm{~N}$ enrichment and recovery. Carbide fuel was proposed to be the reference fuel material for the design studies. As an ambitious choice, block/ plate-type dispersed fuels (carbide fuel dispersed in a $\mathrm{SiC}$ matrix, with $\mathrm{SiC}$ as in-core structural material) was selected as reference. The reference backup (concept robustness) is pintype solid solution fuel. Again, carbide fuel is the reference and, for the cladding, $\mathrm{SiC}$ is the ambitious solution whereas ODS steel is envisioned as the backup solution (even if it may require a revised value for the coolant temperature). Particle fuel was ranked third.

- Core Design: using criteria such as ease of deployment, reactivity effects, ability for passive DHR, and flexibility (burnup increase, volumetric power, transmutation, etc.), selecting core designs is based on common detailed neutronic characterization, thermal-hydraulic assessments, and preliminary evaluation of core's behavior in anticipated transients without scram and follows the fuel and material reference and reference backup recommendations. The reference design must be optimized in the range of 50/50 to $70 / 30$ (for the dispersed fuel composition) and 50 to $100 \mathrm{MW} / \mathrm{m}^{3}$ for the volumetric power to be as near as possible to $100 \mathrm{MW} / \mathrm{m}^{3}$ (Pu inventory criteria). For the pin-type core, refractory alloy claddings are excluded for neutronics and safety considerations. In addition to these reference designs for the second-year detailed studies, some effort will be spent on particle fuel (France) and pebble fuel (U.S.).

- DHR Approach: results concluded that the GT-MHR safety strategy doesn't apply to the GFR, and a wellweighted mix is required between passive, semiactive, and active systems where gas plays a major role (circulators, fiddler crab, injection, natural convection, wall radiation, backup pressure). The general strategy in the definition of the reference safety case for depressurization studies (in particular, choice of the size of the breach), remains to be finalized. The use of in-core devices (heat pipes, heat exchangers, cold legs, etc.) appears to raise many technological and safety questions. In any case, their efficiency remains limited. It has been proposed not to include those types of systems in the reference and reference backup designs.

- Primary System: primary system exploratory studies will be pursued. For the second year studies, it was agreed to select the two following basic options: 1) up-core flow and top-entry refueling, and 2) the 
I-NERI - 2003 Annual Report

rest needing further assessment (position of control rods, vessel material, etc.). More detailed primary and balance of plant (BOP) options will be developed at the end of the contract second year.

Detailed characterization of commonly selected cores is now underway, as are exploratory studies on the choices to be performed for the primary system and BOP. Recent results demonstrate the interest to consider higher power unit (typically $2400 \mathrm{MWt}$ ) to recover margins with respect to the fuel design. In particular, it is identified that the use of a 50/50 cercer fuel would remain compatible with a high level of volumetric power $\left(100 \mathrm{MW} / \mathrm{m}^{3}\right)$ and offers the possibility for an increase of burnup. Based on this consensus, work has been initiated on the second year plant trade studies.
Preliminary results from these on-going trade studies were discussed at the third semi-annual workshop/ meeting held at Cadarache in October 2003.

\section{Planned Activities}

Plant trade studies will be completed and the results documented in the reports shown in the milestone/ deliverable table. These documents will include reports on the core design and GFR safety approach. The trade studies of the natural convection cooling in the block/pin core options will be completed. The work on vessel/ internals/shielding will also be completed. In addition, the experiments to study the deposition of $\mathrm{TiN}$ on carbon-coated oxide ceramic beads will be completed.

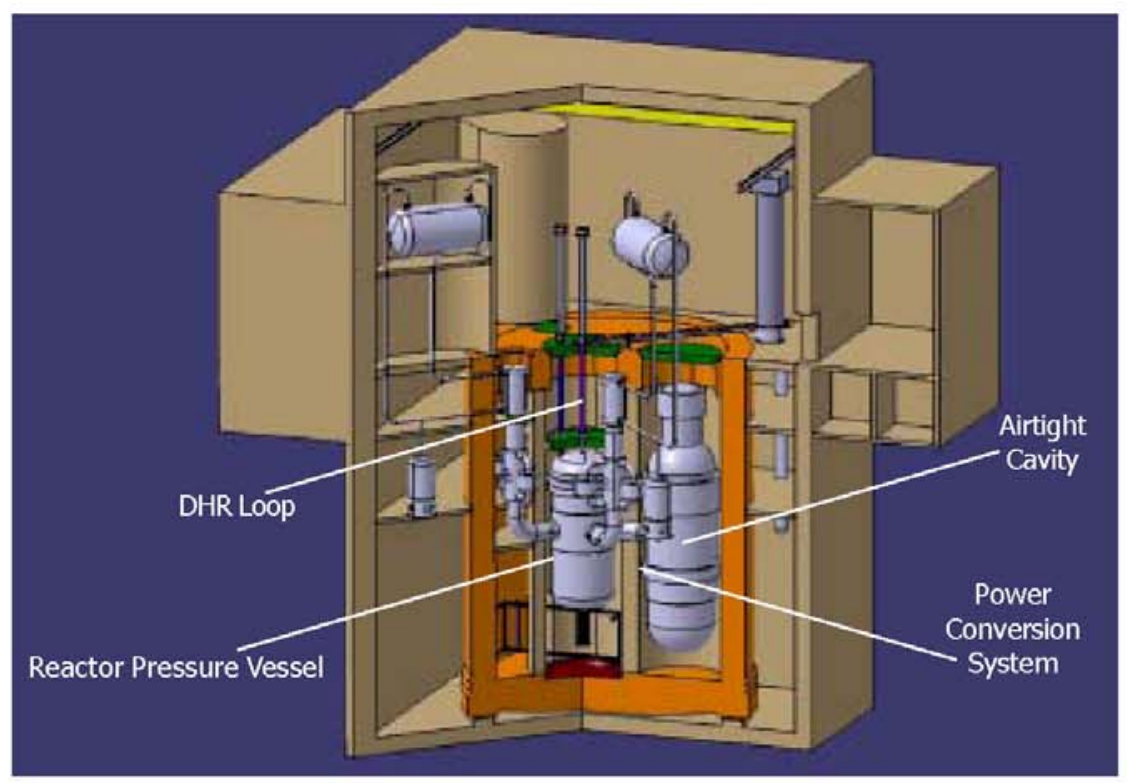

Figure 1. 600 MWth GFR Global Picture 


\section{International Nuclear Energy Research Initiative}

\section{Development of Generation IV Advanced Gas-Cooled Reactors with Hardened/Fast Neutron Spectrum}

Principal Investigator (U.S.): T. Wei, Argonne National Laboratory (ANL)

\section{Principal Investigator (France):} J. Rouault, DEN/DER/SERI CEA-Cadarache

Collaborators: Brookhaven National Laboratory (BNL); General Atomics (GA); Massachusetts Institute of Technology (MIT); Oak Ridge National Laboratory (ORNL); Framatome - ANP (FRA-ANP), Lyon
Project Number: 2001-002-F

Project Start Date: March 1, 2002

Project End Date: February 28, 2005

\section{Research Objective}

The project objective is to design a GFR with a high level of safety and full recycling of the actinides, that also is highly proliferation-resistant and attractive in terms of economics. This three-year project started in March 2002.

\section{Research Progress}

The project has reached the stage where the effort has focused on the characterization of point designs in Year 3. In the initial phase of the project, exploratory studies were performed on a broad range of fuel forms and types, core configurations, coolant types, and primary system/ BOP concepts. Design goals and criteria were specifically formulated for the GFR, and documented to meet the Generation IV criteria/ metrics on economics, sustainability, safety, and non-proliferation. During the course of the initial phase, the major focus of the effort was on innovative concepts to significantly improve the safety level of the GFR over that attained for the Gas-Cooled Fast Reactor (GFR) design of twenty-five years ago, particularly in the area of depressurized decay heat-removal accidents, without compromising the economic competitiveness of the design. Concurrently, an effort was made to preserve the sustainability goal for the GFR core design, which, as all fast reactor core designs, has great flexibility in the choice of fuel cycles. This neutronic flexibility of the GFR core allows the non-proliferation criteria to be successfully incorporated into the design in parallel with the exploration of the sustainability goal. Based on this work, the project is no longer considering the pebble fuel form, oxide fuel, in-core heat exchangers or conduction cooldown. To summarize the conclusions of the exploratory studies, this collaboration between CEA-France and ANL-US partners:

- Developed reactor core design concepts which meet the goal of sustainability (conversion ratio $=1.0$ ) with low proliferation risk (no external blankets) and homogeneous recycling of minor actinides.

- Developed primary system passive decay heat removal concepts for use in combination with the active systems.

- Developed a modular GFR concept (600 MWth), shown in Figure C-1, which incorporates the sustainable core design and passive heat removal features, and makes maximum use of high-temperature VHTR technology (direct cycle, cogeneration capability) to minimize R\&D costs and development time.

With the completion of the exploratory studies, the I-NERI project began a series of trade studies focused on a number of design options identified by the exploratory assessments. The focus was on unit size and a scale-up to a large plant size (2400 MWth) to take advantage not only of 
economics of scale but also to benefit from the decreased neutron leakage which allows reaching the conversion ratio of 1.0 with less challenging fuels while still working at a significant power density $\left(100 \mathrm{MW} / \mathrm{m}^{3}\right)$. In particular, a large factor was to try to reduce the cost of passive design features specifically introduced to significantly improve the decay heat removal performance of the GFR during depressurization accidents with concurrent total loss of $\mathrm{a} / \mathrm{c}$ power. The exploratory studies had concluded that natural convection should be the passive decay removal mechanism of choice. This choice led to the selection of a double containment vessel (guard/proximate) which increases the capital cost of the plant. During the Year 2 trade study phase, significant effort was concentrated on options to reduce this cost. At the start of project year 3, point designs were assembled from different options and combinations, which have been filtered down to:

1. Fuel choice: Dispersed fuel in plate subassemblies as the reference; silicon carbide ( $\mathrm{SiC}$ )-cladded pellets in pin subassemblies as a back-up. The selected actinide compound is carbide in the design studies, but nitride remains a possible candidate.

2. Unit size: 2400 MWth.

3. Power density: $100 \mathrm{MW} / \mathrm{m}^{3}$.

4. Natural convection passive decay heat removal approach, which should be combined with active means (low power circulators) in a well-balanced mix to be refined, but this does not exclude alternative options (search for conduction paths, heavy gas injection, etc.) on which some effort still has to be devoted.

5. Direct Brayton cycle option remains the reference but considerations of the indirect super-critical $\mathrm{CO}_{2} \mathrm{BOP}$ cycle with an equivalent cycle efficiency have also been included.

The conclusion from this work is that encouraging results on the feasibility of the GFR have been obtained. In particular, the proposed concepts are characterized by attractive features regarding safety, which take advantage of the attractiveness of helium in terms of neutronic quasi-transparency and the enhancement of the Doppler effect in connection with the candidate materials selected for the fuel and structural materials. Work is still needed to refine the safety approach and the development of challenging fuels remains a key issue.

\section{Planned Activities}

Effort will be completed on the point design characterization studies of Year 3 and the results will be documented. These reports will form the chapters of the System Design Report (SDR) on the GFR design and safety approach. 


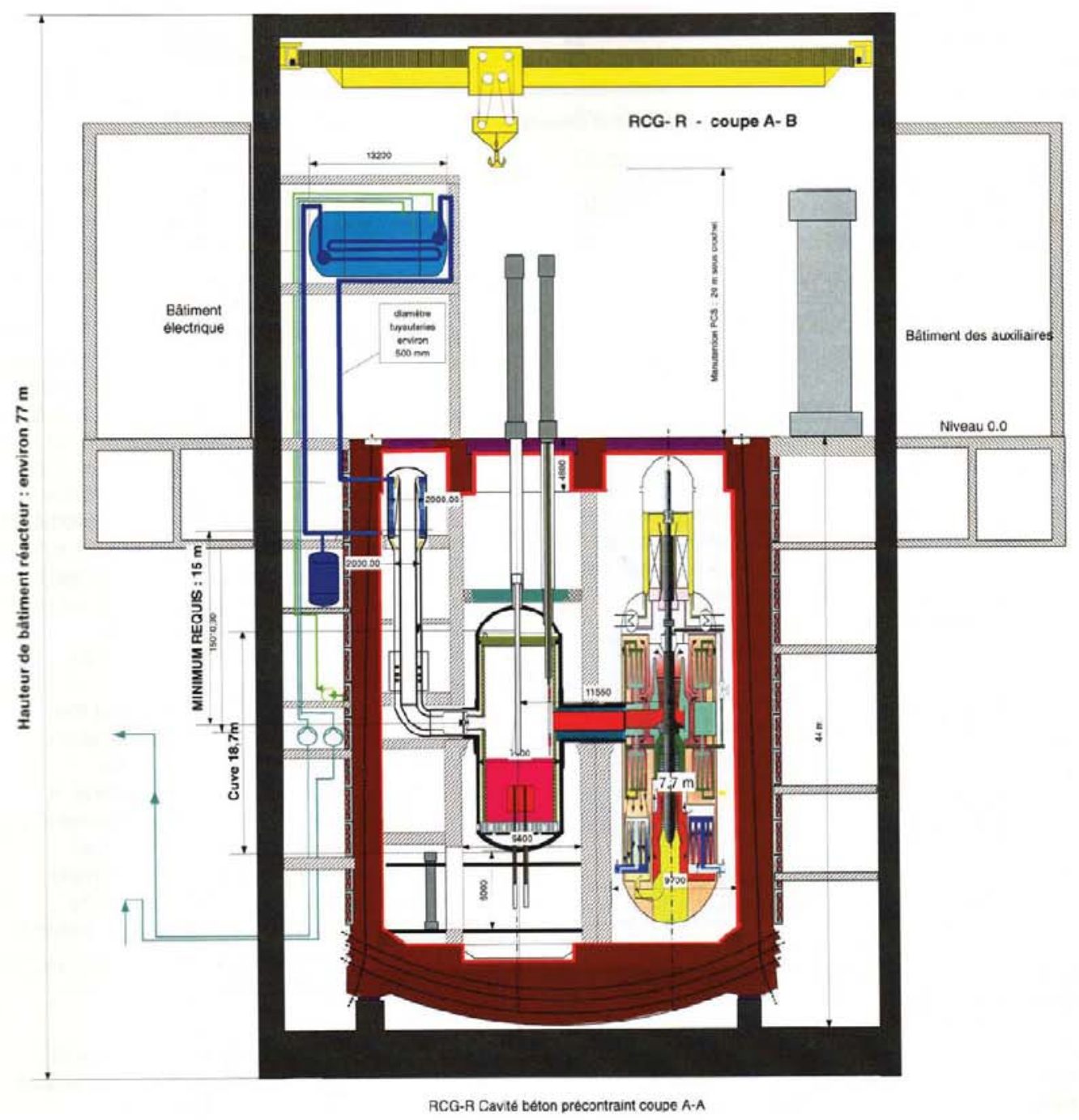

Figure C-1. 600 MWth Modular GFR Concept. 


\section{International Nuclear Energy Research Initiative}

\section{PRA-Aided Design of Advanced Reactors with an Application to GFR Safety-Related Systems}

Principal Investigator (U.S.): K. Weaver, Idaho National Laboratory (INL)

\section{Principal Investigator (France):}

N. Devictor and J. Rouault, Commissariat a' I'Energie Atomique (CEA)

Collaborator: Massachusetts Institute of Technology (MIT)
Project Number: 2004-010-F

Project Start Date: August 1, 2004

Project End Date: August 31, 2007

\section{Project Abstract}

GFRs are contenders of international interest for advanced nuclear power service. It is well recognized, however, that particular attention must be paid to reliable decay heat removal if GFRs are to meet the high expectations for safety assurance established for new reactor designs. Probabilistic Risk Assessment (PRA) has matured over the last thirty years and is expected to play a key role in all aspects of system design and safety. The use of PRA will allow the designers to take advantage of lessons learned from the vast array of PRA applications to LWRs and other reactor types.

There are two major issues that need to be addressed in order to take full advantage of PRA capabilities. First, since currently-operating LWRs do not employ passive systems, PRA models for such systems will have to be developed for advanced reactors. Second, the use of PRA in design implies that there are probabilistic goals that can be used to determine which design is "good enough." Although there are activities by the U.S. Nuclear Regulatory Commission and the International Atomic Energy Agency to establish such probabilistic goals, the current licensing framework is largely "deterministic" and is not expected to change substantially in the near future. This state of affairs raises the issue of whether the design should satisfy the deterministic criteria or the probabilistic goals, especially when a particular design option meets the probabilistic goals but fails the deterministic criteria.
While the proposed project will address both of the issues mentioned above, its focus will be the formulation of the conceptual design of GFR decay heat removal systems that are effective in normal modes of operation as well as normal shutdown, refueling, and, especially, post-loss-of-coolant accident (LOCA) modes, under a range of scenarios including ATWS and station blackout. We will explore the possibility of having safety systems that would be initially active in order to promote economic feasibility. These active systems would be followed by passive, reliable systems that would take over after a pre-determined time for continued core cooling. 
I-NERI — 2005 Annual Report

\section{INTERNATIONAL NUCLEAR ENERGY RESEARCH INITIATIVE}

\section{PRA-Aided Design of Advanced Reactors with an Application to GFR Safety-Related Systems}

PI (U.S.): T.Y.C. Wei, Argonne National Laboratory (ANL)

PI (France): N. Devictor and J. Rouault, Commissariat à I'Energie Atomique (CEA)

Collaborators: Massachusetts Institute of Technology (MIT)
Project Number: 2004-010-F

Project Start Date: August 2004

Project End Date: August 2007

\section{Research Objectives}

This project focuses on formulating the conceptual design of decay heat removal systems for gas-cooled fast reactors (GFR) that will be effective during both normal modes of operation (including shutdown and refueling) and accident conditions (such as following a loss-of-coolant accident [LOCA]). Researchers will evaluate these systems under a range of scenarios, including station blackout and anticipated transients without scram (ATWS).

GFRs are contenders of international interest for advanced nuclear power service; however, particular attention must be paid to reliable decay heat removal if GFRs are to meet the high expectations for safety assurance established for new reactor designs. Probabilistic risk assessment (PRA) has matured over the last 30 years and is expected to play a key role in all aspects of system design and safety. The use of PRA will allow the designers to take advantage of lessons learned from the vast array of PRA applications already developed for light water reactors (LWRs) and other reactor types.

Two major issues must be addressed in order to take full advantage of PRA capabilities. First, since currently operating LWRs do not employ passive systems, PRA models for such systems will have to be developed for advanced reactors. Second, the use of PRA in design implies that there are probabilistic goals to determine which design is "good enough." Although there are activities by the U.S. Nuclear Regulatory Commission and the International Atomic Energy Agency to establish such probabilistic goals, the current licensing framework

NOTE: The work at MIT is supported under NERI 05-044, "Optimized, Competitive Supercritical $\mathrm{CO}_{2}$ Cycle GFR for GEN-IV Service." is largely "deterministic" and is not expected to change substantially in the near future. This raises the issue of whether the design should satisfy the deterministic criteria or the probabilistic goals, especially when a particular design option meets the probabilistic goals but fails the deterministic criteria. This project will also address these issues associated with PRA.

\section{Research Progress}

Passive safety systems are commonly considered more reliable than active ones. The lack of mechanical moving parts or other active components drastically reduces the probability of hardware failure. For passive systems, it is necessary to introduce the concept of "functional failure, i.e., the possibility that the loads will exceed the capacity in a reliability physics framework. In this work, researchers analyzed the passive cooling of a helium-cooled fast reactor in post-LOCA conditions. They used an importance sampling Monte Carlo technique to propagate the epistemic uncertainties and to calculate the probabilities of functional failures. The results showed that functional failures are an important contributor to the overall failure probability of the system and, therefore, should be included in PRA models.

Researchers also performed a comparison with an altemative active design. They quantified the risk of $2-$, 3- and 4-loop designs considering functional failures. The passive system design has no hardware components that can fail; therefore, only functional failures due to epistemic uncertainty contribute to unreliability. For the actively cooled system (with blowers operating), blower failures were included, while functional failures are negligible. Table 1 shows the results for the passive and active systems. 
While the passive system is always more reliable than the active one when functional failures are not considered, this is not the case if their impact is included in the analysis. A comparison of the mean values shows that the active system is actually more reliable than the passive one for the 2- and 3-loop designs. An increase in redundancy is more effective for functional reliability (affecting the passive system) than for hardware reliability (affecting the active system); therefore, for the highly redundant fourloop design, the passive system seems to be better than the active one. It should be pointed out that the calculated failure probability refers to the 72 -hour, steady-state period after the initial transient. The results are conditional on the successful inception of natural (or forced) convection.

Researchers have proposed that the design process for the GFR reactor be accomplished in three phases:

1. From 2005-2007, researchers will conduct a more detailed analysis of potentially acceptable designs, with the objective of choosing a single reference design.

2. From 2008-2012, researchers will improve their analysis of the reference design, particularly improving and optimizing plant systems.

3. The last phase could be the licensing phase.

For each of these three phases, the research team has proposed a four-step risk-informed methodology that not only analyzes the optimization of systems, but analyzes the overall reactor as well.

The principles of the methodology are similar to the one proposed by MIT. The first issue studied was the practical usefulness of this methodology in the first phase. Work has been directed toward developing the proposed methodology with some preliminary studies. The methodology will be applied at the beginning of 2006 on the set of potential designs. The second issue is how to evaluate the reliability of thermal-hydraulic passive systems, such as the one that might be implemented in the GFR reactor, and how to integrate the results obtained into the subsequent PRA studies. Researchers completed initial work within the European RMPS project (Reliability Methods for Passive Safety) coordinated by CEA, which ended in 2004.

Special emphasis was placed on the problem of decay heat removal. Researchers showed that finding passive safety design solutions would be more challenging if helium were chosen as the coolant rather than carbon dioxide. Moreover, a fully passive system for decay heat removal may not necessarily be the safest and most economical solution. That is why PRA studies will be crucial in this

\begin{tabular}{|c|c|c|c|c|}
\hline & & 2 Loops & 3 Loops & 4 Loops \\
\hline $\begin{array}{c}\text { Passive } \\
\text { design }\end{array}$ & & 4.76E-2 & $4.05 \mathrm{E}-4$ & $7.19 \mathrm{E}-6$ \\
\hline \multirow{4}{*}{$\begin{array}{l}\text { Active } \\
\text { design }\end{array}$} & Mean & $5.70 \mathrm{E}-3$ & $1.58 \mathrm{E}-4$ & $7.85 \mathrm{E}-5$ \\
\hline & Median & $3.00 \mathrm{E}-2$ & $1.82 \mathrm{E}-3$ & $1.14 \mathrm{E}-3$ \\
\hline & $5^{\text {th }}$ percentile & $3.00 \mathrm{E}-3$ & $1.68 \mathrm{E}-4$ & $1.06 \mathrm{E}-5$ \\
\hline & $95^{\text {th }}$ percentile & $5.70 \mathrm{E}-2$ & $3.48 \mathrm{E}-3$ & $2.18 \mathrm{E}-3$ \\
\hline
\end{tabular}

Table 1. Probability of failure results for the passive and active systems.

decision-making process. In particular, researchers must find a way to account for the uncertainty in the reliability of passive systems.

Researchers are evaluating the four-step risk-informed methodology developed at MIT to guide the design of future reactor systems. This methodology has many common features with the one proposed by French collaborators. The application of this methodology to the design of the GFR emergency core cooling system was analyzed. This analysis revealed the relevance of combining the rationalist and the structuralist approaches to defense-indepth during the design process.

\section{Planned Activities}

Researchers are working on the time-dependent behavior of a passive decay heat removal system during LOCA transients in a helium-cooled GFR.

Considering the skills and abilities of the research partners, they have agreed to collaborate on the following tasks:

- Developing a risk-informed methodology for design

- Analyzing methodologies for including passive thermalhydraulic systems in the PRA model, particularly the decay-heat removal system

Concerning the first issue, researchers are evaluating the similarities and differences of their different methodologies, with the objective of proposing (if possible) a common approach to risk-informed methodology for design.

Concerning the second issue, the CEA research team will work at a high level, developing and implementing the RMPS methodology for selection of potentially acceptable GFR designs. MIT's research team will work at a lower level, studying specific decay-heat removal systems, including the behavior of passive systems during LOCA transients and the performance of combinations of passive and active systems during these events. 


\section{INTERNATIONAL NUCLEAR ENERGY RESEARCH INITIATIVE \\ PRA-Aided Design of Advanced Reactors with an Application to GFR Safety-Related Systems}

\author{
PI (U.S.): G. Apostolakis, Massachusetts Institute \\ of Technology (MIT) \\ PI (France): N. Devictor, Commissariat à \\ I'Energie Atomique (CEA)
}

Collaborators: None
Project Number: 2004-010-F

Project Start: August 2004

Project End: August 2007

\section{Research Objectives}

The objective of this project is to develop a conceptual design of a decay heat removal system for the gas-cooled fast reactor (GFR). This system will function during both normal modes of operation (including shutdown and refueling) and accident conditions (such as following a loss-of-coolant accident [LOCA]). Researchers will evaluate the system under a range of scenarios, including station blackout and anticipated transients without scram (ATWS).

If GFRs are to meet the high expectations for safety assurance established for new reactor designs, then they must employ a reliable decay heat removal system. Probabilistic risk assessment (PRA), which has matured over the last 30 years, is expected to play a key role in all aspects of system design and safety. PRA will allow the designers to build on the vast array of applications already developed for light water reactors and other reactor types.

Two major issues must be addressed to take full advantage of PRA capabilities for advanced reactors:

1) PRA models for passive systems will have to be developed.

2) The use of PRA in design implies that probabilistic goals exist to determine the acceptability of a design. However, the current licensing framework is largely deterministic, which is not expected to change substantially in the near future.

The U.S. Nuclear Regulatory Commission (NRC) and International Atomic Energy Agency (IAEA) are working to establish probabilistic goals. This raises the issue of whether the design must satisfy both sets of criteria, particularly if a design option meets the probabilistic goals but fails the deterministic criteria.

\section{Research Progress}

The reliability assessment of passive systems focuses on the thermal-hydraulic aspects, i.e., a subset within IAEA passive systems classification that is characterized by moving working fluids, either with or without moving mechanical parts such as check or relief valves. There are several reasons for this emphasis. The most important involve the uncertainties surrounding model predictions and system performance and the variety of possible failure mechanisms that may affect these systems.

Since system failure is no longer characterized by the failure of an active component, a new failure description is required. The concept of "passive function failure," introduced by Burgazzi in 2003, describes failure in terms of a load exceeding the capacity of the system at a certain location. The load is represented as a time-dependent vector that contains a set of performance parameters describing the system safety status. Failure occurs whenever one or more of these parameters exceeds the corresponding value on the capacity vector. Two models are needed: one to predict the system performance and another to describe its capacity.

This project will develop capacity descriptions and the corresponding reliability calculation schemes when no formal models exist. The capacity vector and its time behavior will be specified by aggregating expert opinions. Since the capacity of the system is a function of its state, the capacity changes as the state changes. Introducing a value for time greatly affects the reliability calculation, which is a serious issue for transient calculations. 
In addition, guidelines are required for choosing different failure representations when facing different situations; that is, different capacities need different treatments, given the nature of their intent. For example, whether the analysis is done on a regulatory framework affects the form of the reliability assessment and the corresponding description of the capacity. Three descriptions are proposed: 1) deterministic, 2) epistemic, and 3) aleatory capacities.

Researchers have developed a RELAP5-3D ${ }^{\circledR}$ model of a fully passive, redundant, two-loop decay heat removal system attached to a $600 \mathrm{MW}$ helium-cooled fast reactor. They are using this as the system performance model to demonstrate the applicability of the reliability calculations. The researchers are examining propagation of uncertainties through the model using Latin Hypercube Sampling of over seven independent parameters. The work captures system dynamic behavior during the transient following a LOCA to verify that the performance criteria are satisfied. The researchers have gained insight into features of the system dynamics under different operational conditions that were useful in development of the model. They can also offer a perspective on the future steps to improve the description of passive system failure mechanisms.

Researchers have analyzed the passive cooling of a helium-cooled fast reactor in quasi-steady state post-LOCA conditions. They used an importance sampling Monte Carlo technique to propagate the epistemic uncertainties and to calculate the probabilities of function failures for comparison with an active design. Previous work showed that active systems are more reliable than passive for two- and three-loop designs, while the passive design was more reliable in the four-loop configuration. By employing larger uncertainties in some physical parameters, derived from more recent correlation formulas, and by modifying the previous results, the researchers showed that the failure probability of the active four-loop configuration is lower than for the passive design. These results need to be coupled with those from the transient study to give a complete view of the reliability of the passive decay heat removal system design.

\section{Planned Activities}

Researchers will continue to finalize the analysis of time-dependent behavior of a passive decay heat removal system during LOCA transients in a helium-cooled GFR. Time-dependent situations are complex and their inclusion in PRA models is challenging. By analyzing transient failure modes, researchers will obtain a more precise picture of the decay heat removal system based on passive phenomena. This is a necessary step before including passive thermal-hydraulic systems in the PRA model.

The researchers have evaluated the similarities and differences of their PRA methodologies. They have found that methodologies are similar, but lack an explicit treatment of transients; this will constitute a major task for the next period.

Finally, the team will study specific decay-heat removal systems, including the behavior of passive and active systems during LOCA transients, to develop probabilistic criteria for determining the acceptability of a design. 


\begin{abstract}
INTERNATIONAL NUCLEA
PRA-Aided De
With an Application
PI (U.S.): G.E. Apostolakis, Massachusetts
Institute of Technology (MIT)
PI (France): F. Bertrand, Commissariat à

I'énergie atomique (CEA)

Collaborators: None
\end{abstract}

EARERGY RESEARCH INITIATIVE

\author{
PRA-Aided Design of Advanced Reactors
}

Project Number: 2004-010-F

Program Area: Generation IV

Project Start Date: April 2005

Project End Date: April 2008

\section{Research Objectives}

The objective of this project was to develop a conceptual design of a decay heat removal system for the gas-cooled fast reactor (GFR). This system will function during both normal modes of operation (including shutdown and refueling) and accident conditions. Researchers evaluated the system under a range of scenarios, including loss-ofcoolant accidents (LOCA), station blackout, and anticipated transients without scram (ATWS).

For GFRs to meet the high standards for safety assurance expected of new reactor designs, they must employ a reliable decay heat removal system. Probabilistic risk assessment (PRA), which has matured over the last 30 years, is expected to play a key role in all aspects of system design and safety. PRA will allow the designers to build on the vast array of applications already developed for light water reactors and other reactor types.

Two major issues must be addressed to take full advantage of PRA capabilities for advanced reactors: 1) PRA models for passive systems must be developed and 2) the use of PRA in design implies that probabilistic goals exist to determine the acceptability of a design. However, the current licensing framework is largely deterministic, which is not expected to change substantially in the near future.

The Nuclear Regulatory Commission (NRC) and International Atomic Energy Agency (IAEA) are working to establish probabilistic goals. It is uncertain whether a new plant design would need to satisfy both deterministic and probabilistic criteria, particularly if a design option meets probabilistic goals but fails the deterministic criteria.

\section{Research Progress}

According to an IAEA definition, passive systems are either composed of passive components and structures, or they use active components in a very limited manner to initiate subsequent passive operation. Of great importance are thermal-hydraulic $(\mathrm{T}-\mathrm{H})$ systems that fall under IAEA Categories B and C. These are characterized by moving working fluids and can contain moving mechanical parts such as check or relief valves.

Overall plant reliability should increase by replacing certain active systems with passive, as the external energy source is a primary contributor to unreliability of active systems. Passive system functionality does not rely on an external source of energy, but on an intelligent use of natural phenomena, such as gravity, conduction and radiation, which are always present. Although natural driving forces are always available for a passive system, they are normally weak, which is particularly significant for systems that depend on natural circulation of fluids. In addition, operators cannot control passive systems the way they can control the performance of active systems.

Since system failure is no longer characterized by the failure of an active component, a new failure description is required. The concept of "passive functional failure" describes failure in terms of exceeding a system's load capacity at a certain location. The load is represented as a time-dependent vector that contains a set of performance parameters describing the system safety status. Failure occurs whenever one or more of these parameters exceed the corresponding values of the capacity vector. The load vector reflects the epistemic uncertainties in the calculations 
while the capacity vector is fixed at the regulatory limits, i.e., the maximum temperature in the cladding and in the hot leg of decay heat removal (DHR) loops.

The reliability assessment of passive systems focuses on the thermal-hydraulic aspects for several reasons. The most important involve the uncertainties surrounding model predictions and system performance and the variety of possible failure mechanisms that may affect these systems.

The GFR design considered consists of a 600 MWth helium-cooled fast reactor, a Brayton cycle power conversion unit (PCU), and two 50 percent DHR loops (Figure 1). The core is designed to have very low pressure drop to maximize the natural circulation capability. A guard containment building with a design pressure of $2 \mathrm{MPa}$ (20 bar) ensures that, after primary system depressurization, the backpressure would be high enough to accomplish DHR by natural circulation of helium.

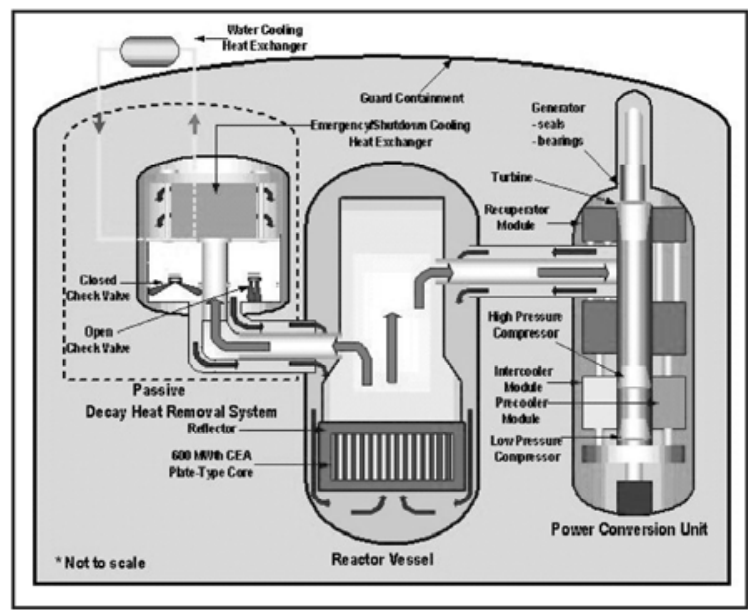

Figure 1. Schematic GFR system layout.

Each DHR loop consists of two separate circuits. The first connects to the pressure vessel through a coaxial pipe, with the outer portion the cold leg. Heat is delivered to a second water-filled circuit through a heat exchanger that discharges the heat to a pool outside the containment building. The Brayton power cycle PCU, with recuperator, precooler, and intercooler, provides energy to the generator and to the low- and high-pressure compressors.

Researchers have completed two studies. The first performed a time-dependent reliability evaluation of a two-loop passive DHR system as part of the iterative design process for the GFR. The system was modeled using RELAP5-3D and uncertainties in input parameters were assessed and propagated through the model using
Latin Hypercube Sampling. An important finding was that flow would bypass the core through one DHR loop, if two loops operated in parallel, due to the smaller pressure loss through the DHR heat exchanger. This finding is a warning against modeling only a single lumped DHR loop and assuming that multiple loops will remove $\mathrm{n}$ times the decay heat. The initial design consisted of two 50 percent DHR loops working in parallel; this configuration was modified because of the core bypass possibility. Each DHR loop is now designed to extract 2 percent of the reactor nominal power (i.e., $12 \mathrm{MWth}$ ) at a back-pressure of $1.3 \mathrm{MPa}$.

Sensitivity analyses revealed that there are values of some input parameters for which failures are very unlikely. Figure 2 shows such a plot for the two leakages associated with each Monte Carlo realization (one for each DHR loop) for the maximum temperature in the cladding. On the horizontal axis, researchers plotted the maximum of the two leakages and on the vertical axis the minimum. The plus signs indicate a realization and the square around a plus sign indicates a failure of the cladding. Because no failures occurred below the dashed line (lower left corner), the researchers concluded that maximum leakage in the loops less than about $0.8 \mathrm{~kg} / \mathrm{s}$ and minimum leakage less than about $0.5 \mathrm{~kg} / \mathrm{s}$ preclude clad failure.

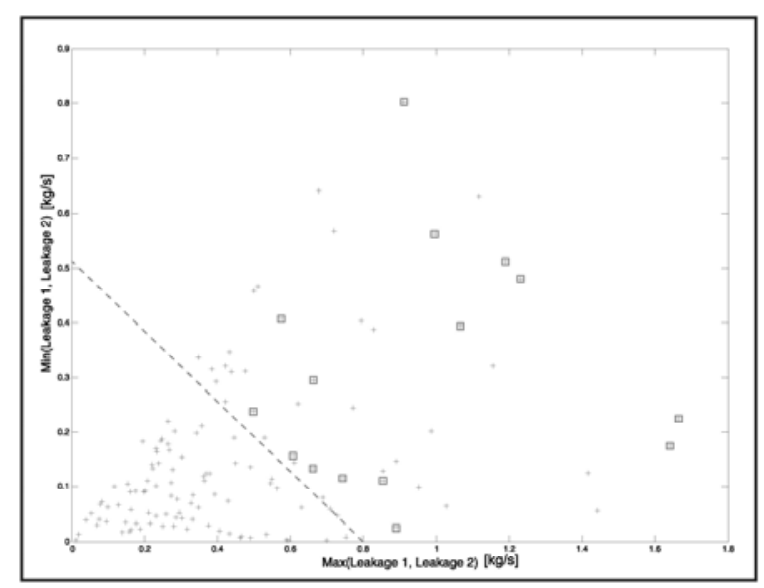

Figure 2. Leakage Threshold Effect (cladding failure).

Following is the explanation for this behavior. After the shaft stops, the system attempts to open the check valves by overcoming the leakage. The valve with the smallest leakage is the one that eventually opens. The higher the minimum leakage, the later the check valve opens. Such a delay means that more heat has been deposited in the core with no extraction and, therefore, the temperature has increased. 
Once the valve opens, natural circulation develops through the corresponding DHR loop, but part of the fluid in the lower plenum is taken by the other DHR loop's leakage and transferred directly to the upper plenum, thus bypassing the core. The higher the maximum leakage, the smaller mass flow is available to the core for heat removal. Failure is the combined effect of the two quantities and, as Figure 2 shows, only values outside the lower triangle can lead to failure.

The calculated conditional failure probability (i.e., given the LOCA) was deemed too high, which led to the identification of several design changes to improve system reliability. A sensitivity analysis showed that check valve leakages were most important. An adiabatic boundary condition between the two coaxial DHR pipes was assumed meaning that, for the purpose of that study, they were actually separated. The adiabatic assumption was introduced for model simplification to reduce computational time, as nearly all heat transfer is through the heat exchangers and heat losses from the hot leg to the cold leg are small.

Some improvements to the system were suggested, such as relaxing the perfect insulation assumption between the two pipes by inserting insulation material on the inner side of the hot leg, combined with an increase in containment backup pressure in order to increase the mass flow rate in the DHR loop. This study is an example of the kinds of insights that can be obtained by including a reliability assessment in the design process. It is different from the usual use of PRA in design, which compares different system configurations, because it focuses on the thermal-hydraulic performance of a safety function.

The second study (Patalano et al.) investigated a number of design options aimed at reducing the conditional failure probability. The design chosen for detailed investigation placed insulation material on the outer surface of the hot pipe, covered by a $2.7 \mathrm{~mm}$ stainless steel foil. This foil prevents small particles from being detached and brought along in the loop by the gas causing damage to the structures or occlusions in the core channels.

The parameter and model uncertainties were propagated through the RELAP5-3D code, using a sample size of 128 . As stated earlier, two failure limits were considered: one for the fuel and one for the DHR structure. The purpose of these calculations was to evaluate possible improvements with respect to the basic design and previous findings on the conditional failure probability of the passive system. Figure 3 shows the temperature profiles for 128 cases in the steel structure of both DHR loop hot pipes. The DHR system is composed of two 100 percent loops, only one of which operates while the other remains closed. Consequently, Figure 3 has 256 curves: the always-decreasing temperature profiles are those for the closed loop, in which the temperature decreases because the hot helium is passing through only the open loop. The curves with a local minimum point between 2,000 and 3,000 seconds are the temperature evolutions of the hot leg pipe in the open loop. There are 14 realizations that exceed the failure criterion of $1,123.15 \mathrm{~K}$ and would lead to structural failure of the DHR pipes, giving a total failure probability of 0.125 .

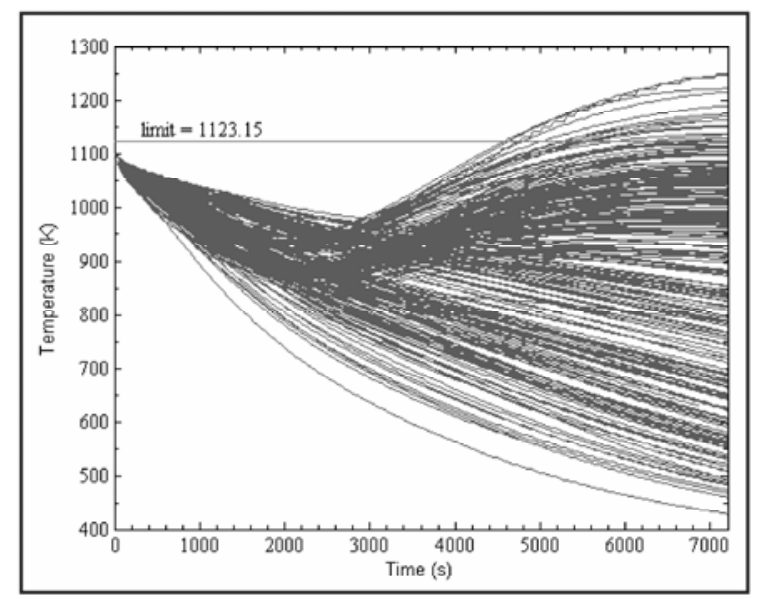

Figure 3. Temperature evolutions in the DHR loop hot pipes for 128 samples.

Extensive sensitivity analyses were conducted by Patalano et al. It was concluded that the parameter whose reduction in uncertainty would reduce the output uncertainty the most is the thermal conductivity of the insulation. The second most important parameter is the heat transfer coefficient in the containment. All the parameters have an impact on the mean maximum temperature. It appears that the roughness is an irrelevant parameter with respect to the output.

An important conclusion of this work was that a purely passive GFR system had a high conditional probability of failure that was difficult to reduce significantly. With design changes, researchers obtained a reduction by roughly a factor of five in the failure probability. However, the conditional probability was still deemed to be high. Therefore, a reliable active system appeared to be better suited for this particular application. Results led the MIT design team to adopt an active DHR as the main mode of decay heat removal for the GFR. 
I-NERI - 2007 Annual Report

\section{Planned Activities}

In 2008, a final report will be prepared by MIT and CEA. It will contain the major findings produced by this project and recommendations as to how the unreliability of passive cooling safety systems can be evaluated. 


\section{NUCLEAR ENERGYORESEARCH INITLATIVE}

Optimized, Competitive Supercritical- $\mathrm{CO}_{2}$ Cycle GFR for Generation IV Service

\section{PI: Michael J. Driscoll, Massachusetts \\ Institute of Technology}

Collaborators: None
Project Number: 05-044

Project Start Date: March 2005

Project End Date: February 2008

\section{Project Description}

This project will develop an integrated overall plant design for a gas-cooled fast reactor (GFR) based on the compact and highly efficient, direct supercritical carbon dioxide $\left(\mathrm{CO}_{2}\right)$ Brayton cycle. This plant will be capable of performing a full spectrum of desired Generation IV objectives, including economical electric power generation, high uranium utilization, the ability to burn transuranics and/or minor actinides, and production of hydrogen through the high-temperature electrolysis of steam. There are tradeoffs associated with achieving attractive economics and assuring a high degree of safety for the final plant design. Researchers will use probabilistic techniques to optimize these tradeoffs and develop a design that is both economical and safe. In addition, researchers will use existing Nuclear Regulatory Commission (NRC) deterministic prescriptions and proposed risk-informed licensing requirements to evaluate prospective plant designs.

Most worldwide research on this type of gas reactor is based on a helium cycle that operates at temperatures approaching $900^{\circ} \mathrm{C}$, which poses severe core and component material challenges. This $\mathrm{S}-\mathrm{CO}_{2}$ cycle can achieve high thermodynamic efficiency (approximately 44 percent to 51 percent) at modest temperatures of 550 to $650^{\circ} \mathrm{C}$. Therefore, creative synthesis of proven technology should suffice in many instances. The focal point of the major tasks of this project will be designing the reactor core and the decay heat removal systems. Overall, this project will provide a sufficient basis for assessing this type of GFR among the candidate Generation IV designs being evaluated for final selection.

\section{Work Scope}

Task 1. Core Design and Performance Assessment.

- Optimize features of vented fuel concept using tube-induct assemblies.

- Develop pin type core design as a benchmark for comparisons and as a fallback option.

- Confirm the burning capability of TRU and minor actinides.

\section{Task 2. PRA Guided Design of Safety Systems.}

- Develop decay heat removal design for accident, normal shutdown, and refueling.

- Develop improved emergency power systems, such as microturbines or fuel cells.

- Develop both active and passive means of shutdown assurance to preclude an anticipatory transient without scram (ATWS).

\section{Task 3. Overall Plant Design and Economic}

\section{Assessment}

- Design power cycles for core exit temperatures ranging from 550 to $700^{\circ} \mathrm{C}$.

- Demonstrate integration with high-temperature electrolysis of steam for $\mathrm{H}_{2}$ production.

- Estimate busbar costs of electricity relative to other reactor options. 


\section{NUCLEAR ENERGYRESEARCH INITLATIVE}

\section{Optimized, Competitive Supercritical- $\mathrm{CO}_{2}$ Cycle GFR for Generation IV Service}

\section{PI: Michael J. Driscoll, Massachusetts \\ Institute of Technology (MIT)}

Collaborators: None

\author{
Project Number: 05-044
}

Project Start Date: April 2005

Project End Date: April 2008
Research Objectives

This project will develop a complete, integrated plant design for a gas-cooled fast reactor (GFR) based on the compact and highly efficient, direct supercritical carbon dioxide $\left(\mathrm{S}-\mathrm{CO}_{2}\right)$ Brayton cycle (which is also under development at MIT for Generation IV service). This plant will be capable of performing a full spectrum of Generation IV objectives, including economical electric power generation, high uranium utilization, the ability to burn transuranics and/or minor actinides, and production of hydrogen through the high-temperature electrolysis of steam. Researchers will evaluate prospective plant designs using existing Nuclear Regulatory Commission (NRC) deterministic prescriptions and proposed riskinformed licensing requirements. They will also use probabilistic techniques to optimize the tradeoffs between economics and safety assurance.

Most worldwide research on this type of gas reactor is based on a helium cycle that operates at temperatures approaching $900^{\circ} \mathrm{C}$, which poses severe challenges to the core and component materials. Because the $\mathrm{S}-\mathrm{CO}_{2}$ cycle can achieve high thermodynamic efficiency (approximately 44 percent to 51 percent) at modest temperatures (from 550 to $650^{\circ} \mathrm{C}$ ), researchers can utilize already proven technologies in their design.
Major tasks of this project will focus on designing the reactor core and the decay heat removal systems. In designing the core, researchers will optimize features of the vented fuel concept using tube-in-duct assemblies, develop a pin-type core design as a benchmark, and confirm the capability of burning TRU and minor actinides. Safety system design, guided by probabilistic methods, will involve development of a decay heat removal system for accidents, shutdown, and refueling; improvement of emergency power, such as microturbines or fuel cells; and integration

\begin{tabular}{|c|c|c|}
\hline Core & & Comments \\
\hline Fuel & $\mathrm{UO}_{2}+\mathrm{BeO}$ & LWR TRU fissile \\
\hline Clad & ODS, MA 956 & SiC a long range possibility \\
\hline Configuration & $\begin{array}{l}\text { tube-in-duct fuel assemblies, } \\
\text { "hexnut" pellets, vented, orificed }\end{array}$ & pin-type core as fallback \\
\hline Thermal-Hydraulics & $\begin{array}{l}\text { axial peaking factor } \leq 1.3 \\
\text { radial peaking factor } \leq 1.3 \\
\text { power density } \geq 85 \mathrm{~W} / \mathrm{cc}\end{array}$ & $\begin{array}{l}\text { vary BeO fraction } \\
\text { to flatten power } \\
\text { lower than GA GCFR of } \\
1970 \text { 's@235 W/cc }\end{array}$ \\
\hline Burnup & $\geq 120 \mathrm{MWd} / \mathrm{kg}$ (avg) & In single batch core \\
\hline \multicolumn{3}{|l|}{ Safety Systems } \\
\hline Auxiliary Loops & $\begin{array}{l}\text { combined shutdown \& } \\
\text { emergency, } 4 \text { x } 50 \% \text { capable, } \\
\text { forced convection; } \\
\text { natural convection supplemented } \\
\text { water boiler heat sink }\end{array}$ & $\begin{array}{l}\text { based on MIT/CEA/ANL } \\
\text { INERI project design. For } \\
\mathrm{P} \geq 0.5 \mathrm{MPa} \text { natural } \\
\text { convection alone may } \\
\text { suffice }\end{array}$ \\
\hline Emergency Power & fuel cells to supplement diesels & $\begin{array}{l}\text { projected to be more } \\
\text { reliable than diesels alone } \\
\text { in long run }\end{array}$ \\
\hline \multicolumn{3}{|l|}{ Plant } \\
\hline Power Cycle & $\begin{array}{l}\text { supercritical } \mathrm{CO}_{2} \text { Brayton direct } \\
4 \times 300 \mathrm{MWe} \text { loops }=1200 \mathrm{MWe} \\
\text { core exit/turbine inlet } \\
550^{\circ} \mathrm{C} \leq \mathrm{T} \leq 700^{\circ} \\
\text { pressure: } 20 \mathrm{MPa}\end{array}$ & $\begin{array}{l}\text { AGRs in } \mathrm{UK} \text { use } \mathrm{CO}_{2} \\
\text { coolant at } 4 \mathrm{MPa} \text { and } \\
\text { have } \mathrm{T} \sim 650^{\circ} \mathrm{C}\end{array}$ \\
\hline Reactor Vessel & PCRV, PCIV or Steel & $\begin{array}{l}\text { 20MPa is challenge } \\
\text { for PCRV and } \\
\text { perhaps PCIV }\end{array}$ \\
\hline
\end{tabular}

Table 1. Initial GFR Plant Features. 
of both active and passive means of shutdown assurance to preclude an anticipated transient without scram (ATWS). The final design will be optimized for integration with a high-temperature steam electrolysis process for hydrogen production, and an economic assessment will be conducted to estimate costs. Overall, this project will provide a sufficient basis for assessing this type of GFR among the candidate

Generation IV designs being evaluated for final selection.

\section{Research Progress}

Work has been initiated in most of the task areas. The principal achievement has been the development of an initial reference design that has features consistent with the project's goals, as shown in Table 1 . The most significant design feature is the radially powered flattened core. As shown in Figure 1, the maximum peaking factor over core lifetime is only 1.2 for batch-irradiated core driven to $120 \mathrm{MWd} / \mathrm{kg}$ average bumup. The key innovation that allows this performance is the use of radial variation of beryllium oxide $(\mathrm{BeO})$ diluent in the fuel. The concurrent spectral softening also yields a coolant void reactivity of less than one dollar over core lifetime. Furthermore, the BeO increases fuel conductivity by about 50 percent. In conjunction with the use of "hexnut" shaped annular fuel pellets, instead of researchers ${ }^{\prime}$ original plans to use VIPAC fuel, this considerably enhances the thermalhydraulic performance of the vented tube-in-duct fuel assemblies.

\section{Planned Activities}

The most significant next step will be to carry out RELAP5-3D transient thermal hydraulic analyses of candidate core designs coupled to a complete plant model, including both the power conversion and shutdown cooling systems. Converging upon a suitable fuel assembly configuration is an essential prerequisite to demonstrating other important fuel cycle goals such as minor actinide burning. These RELAP calculations, in conjunction with PRA analyses, are also important to finalizing the shutdown cooling system design, including balancing between active and passive features as a function of pressure and postshutdown time, since to date the design has been based on quasi-steady-state analyses.

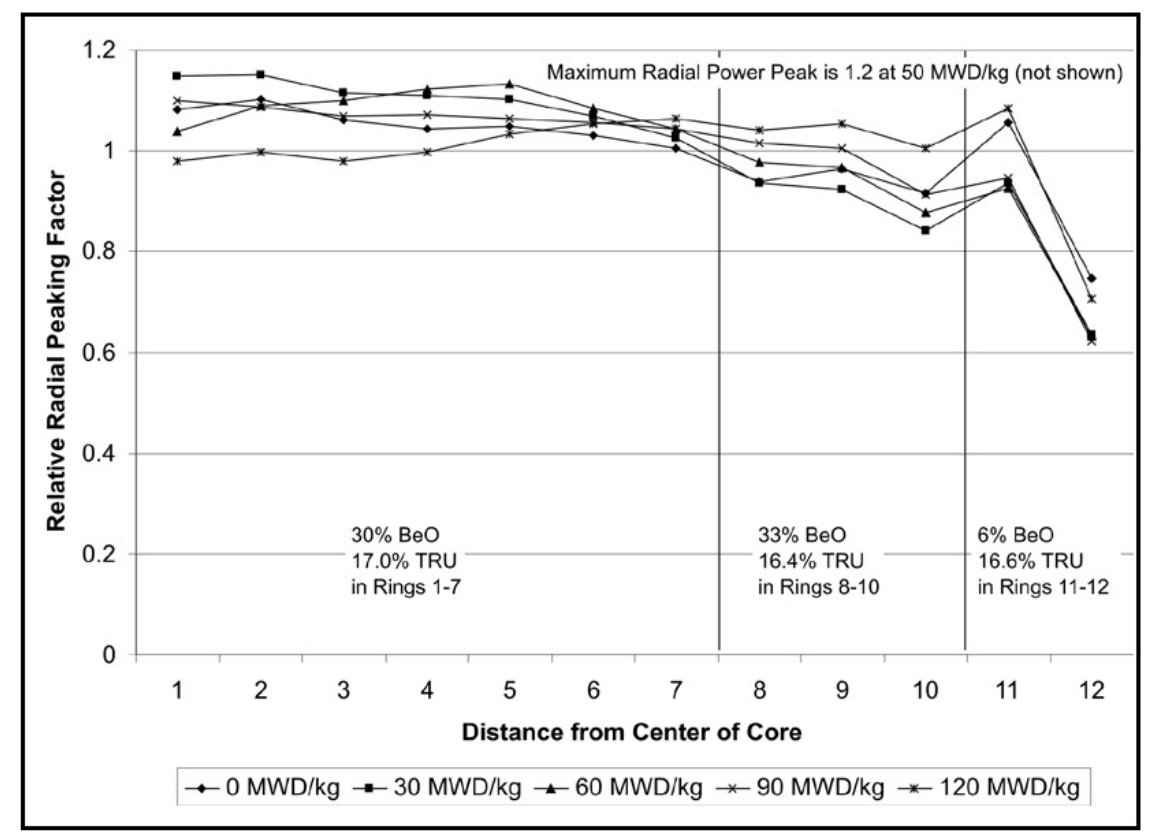

Figure 1. Reference power-flattened GFR core performance. 


\section{NuCLEAR ENERGYORESEARCH INITLATIVE}

Optimized, Competitive Supercritical- $\mathrm{CO}_{2}$ Cycle GFR for Generation IV Service

\author{
PI: Michael J. Driscoll, Massachusetts \\ Institute of Technology (MIT)
}

Collaborators: None
Project Number: 05-044

Project Start Date: April 2005

Project End Date: April 2008
Research Objectives

This project is developing an integrated overall plant design for a gas-cooled fast reactor (GFR) based on the compact and highly efficient, direct supercritical carbon dioxide $\left(\mathrm{S}-\mathrm{CO}_{2}\right)$ Brayton cycle under development at $\mathrm{MIT}$ for Generation IV service. This plant will be capable of economical electric power generation, high uranium utilization, burning of transuranics (TRU) and/or minor actinides, and hydrogen production through the hightemperature electrolysis of steam. Researchers are evaluating prospective plant designs using existing Nuclear Regulatory Commission (NRC) deterministic regulations and proposed risk-informed licensing requirements. They are applying probabilistic techniques to optimize the tradeoffs between economics and safety assurance.

Most worldwide research on this type of gas reactor is presently based on a helium cycle that operates at temperatures approaching $900^{\circ} \mathrm{C}$, which poses severe challenges to the core and component materials. Because the $\mathrm{S}-\mathrm{CO}_{2}$ cycle can achieve high thermodynamic efficiency (approximately 44 to 51 percent) at modest temperatures of 550 to $650^{\circ} \mathrm{C}$, researchers can utilize already-proven technologies in their design.

Major tasks of this project focus on designing the reactor core and the decay heat removal systems. In designing the core, researchers have optimized features of the vented fuel concept using tube-in-duct (TID) assemblies. In addition they are developing a pin-type core design as an alternative and are confirming the capability of burning TRU and minor actinides. Design of the safety system is guided by probabilistic methods and involves developing a decay heat removal system for accidents, shutdown, and refueling; improving emergency power, such as microturbines or fuel cells; and integrating both active and passive means of shutdown assurance to preclude an anticipated transient without scram (ATWS). Researchers will optimize the final design for integration with a hightemperature steam electrolysis process for hydrogen production and they will conduct an economic assessment to estimate costs. Overall, this project will provide a sufficient basis for assessing this type of GFR among the other candidate Generation IV designs being evaluated for final selection.

\section{Research Progress}

The current status of the plant design, incorporating all changes implemented during the first 20 months of the project's efforts, is summarized in Table 1 . Following is a summary of the noteworthy developments.

Figure 1 illustrates the overall plant layout coupling the reactor to supercritical $\mathrm{CO}_{2}$ Brayton power conversion units.

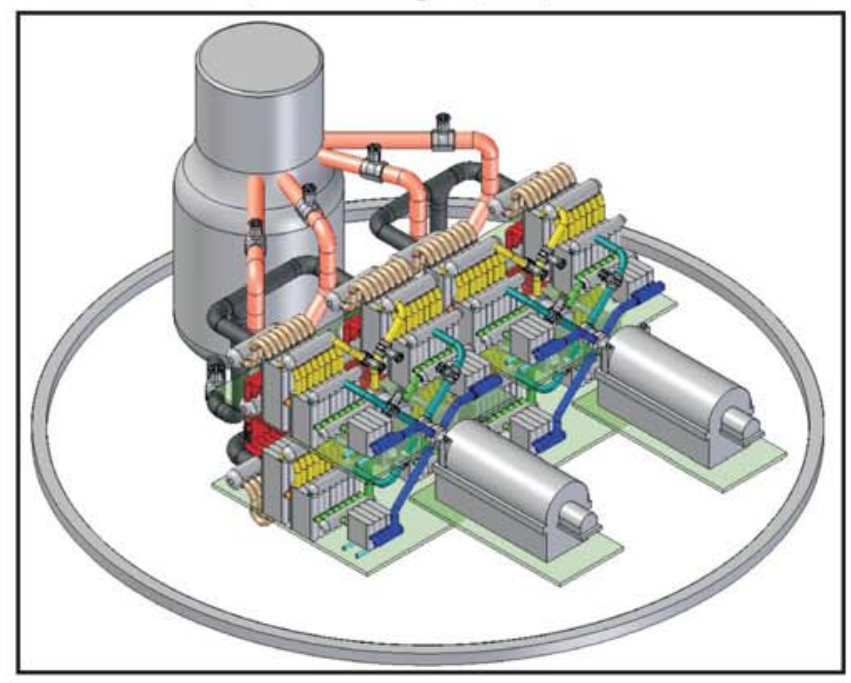

Figure 1. Arrangement of reactor and power conversion units. 
NERI - 2006 Annual Report

\begin{tabular}{|c|c|c|}
\hline Subsystem & Features & Comments \\
\hline \multicolumn{3}{|l|}{ Core } \\
\hline Fuel & $\mathrm{UO}_{2}+\mathrm{BeO}$ & LWR TRU fissile \pm MA \\
\hline Clad & ODS-MA956, or HT-9 & $\mathrm{SiC}$ a long range possibility \\
\hline Configuration & $\begin{array}{l}\text { tube-in-duct fuel } \\
\text { assemblies, "hexnut" } \\
\text { pellets, vented, orificed }\end{array}$ & pin-type core as fallback \\
\hline Thermal-Hydraulics & $\begin{array}{l}\text { axial peaking factor } \leq 1.3 \\
\text { radial peaking factor } \leq 1.2 \\
\text { power density } \sim 85 \mathrm{~W} / \mathrm{cc}\end{array}$ & $\begin{array}{l}\text { Vary BeO fraction to flatten } \\
\text { power. Lower than GA } \\
\text { GCFR of } 1970 \text { s @ } 235 \\
\text { W/cc }\end{array}$ \\
\hline Burnup & $\geq 120 \mathrm{MWd} / \mathrm{kg}$ (avg) & $\begin{array}{l}\text { In single batch no-reshuffle } \\
\text { core, } 17-\mathrm{yr} \text { lifetime }\end{array}$ \\
\hline \multicolumn{3}{|l|}{ Safety Systems } \\
\hline Auxiliary Loops & $\begin{array}{l}\text { combined shutdown \& } \\
\text { emergency, } 4 \text { × 50\% } \\
\text { capable, forced convection; } \\
\text { natural convection } \\
\text { supplemented water boiler } \\
\text { heat sink }\end{array}$ & $\begin{array}{l}\text { Based on MIT/CEA/ANL } \\
\text { INERI project design. } \\
\text { For } P \geq 0.7 \mathrm{MPa} \text { natural } \\
\text { convection alone may } \\
\text { suffice }\end{array}$ \\
\hline Emergency Power & $\begin{array}{l}\text { Fuel cells to supplement } \\
\text { diesels }\end{array}$ & $\begin{array}{l}\text { Projected to be more } \\
\text { reliable than diesels alone } \\
\text { in long run }\end{array}$ \\
\hline \multicolumn{3}{|l|}{ Plant } \\
\hline $\begin{array}{l}\text { Power Conversion System } \\
\text { (PCS) }\end{array}$ & $\begin{array}{l}\text { supercritical } \mathrm{CO}_{2} \text { Brayton } \\
\text { direct } 2 \times 600 \mathrm{MWe}^{\circ} \\
\text { loops }=1200 \mathrm{MWe} ; 650^{\circ} \mathrm{C} \\
\text { core exit/turbine inlet, } \\
\text { pressure: } 20 \mathrm{MPa}\end{array}$ & $\begin{array}{l}\text { AGRs in UK use } \mathrm{CO}_{2} \\
\text { coolant at } 4 \mathrm{MPa} \text { and have } \\
\mathrm{T} \sim 650^{\circ} \mathrm{C}\end{array}$ \\
\hline Reactor Vessel & PCIV & $\begin{array}{l}\text { Vessel houses loop } \\
\text { isolation and check valves } \\
\text { plus shutdown cooling heat } \\
\text { exchangers }\end{array}$ \\
\hline Containment & $\begin{array}{l}\text { PWR type, steel liner } \\
\text { reinforced concrete } 0.7 \\
\text { MPa design capability, } \\
70,000 \mathrm{~m}^{3} \text { free volume } \\
\text { filtered/vented }\end{array}$ & $\begin{array}{l}\mathrm{CO}_{2} \text { can be added to } \\
\text { adjust pressure. Internally } \\
\text { insulated }\end{array}$ \\
\hline $\begin{array}{l}\mathrm{H}_{2} \text { production by steam } \\
\text { electrolysis }\end{array}$ & $\begin{array}{l}\text { Separate water boiler loops } \\
\text { (4) @ } 10 \% \text { of reactor power } \\
\text { Recuperation of } \mathrm{H}_{2} \& \mathrm{O}_{2} \\
\text { heat allows cell operation } \\
\text { at } 850^{\circ} \mathrm{C}\end{array}$ & $\begin{array}{l}\text { Water boiler loops can } \\
\text { also serve for self-powered } \\
\text { decay heat removal }\end{array}$ \\
\hline
\end{tabular}

Table 1. Current status of GFR plant features.

The arrangement shown fits inside a conventional $54 \mathrm{~m}$ inner-diameter PWR-type containment building.

Researchers developed a final version of a tube-induct assembly core and presented the results at PHYSOR 2006. A unique feature was the use of radial reflector assemblies as conduits for the $\mathrm{CO}_{2}$ coolant. This, plus the use of beryllium oxide $(\mathrm{BeO})$ diluent in the fuel, yielded a core having a negative coolant void reactivity over its burnup lifetime without significant penalties to other performance criteria. An improved flow-levitated absorber 24 was developed, and a prototype was tested in the laboratory which provides a passive means to ensure reactivity insertion during loss of coolant accident (LOCA) or loss of flow (LOF) events. The basis for core self-protection, however, remains the incorporation of integral fast reactortype inherent reactivity feedbacks (e.g., Doppler, expansion, etc.) to ensure quasi-static compensation. Significant progress was made on both steady state and transient/ accident thermal-hydraulic analyses. The results were published as a major topical report.

Researchers have developed a steady-state core design that utilizes an innovative, high-fuelvolume fraction, vented, tubein-duct fuel assembly. After performing an extensive series of iterative calculations, researchers used RELAP5-3D to evaluate the natural circulation performance of an active/passive hybrid Shutdown/ Emergency Cooling System (SCS/ ECS). The routes were identified by which significant post-LOCA core bypass could occur and degrade the decay heat removal performance. Moderately sized blowers were shown to be capable of overcoming even extreme core bypass routes. A highly reliable active SCS/ECS was thus adopted for the reference design.

The loss of external load event was analyzed and a bypass valve scheme recommended that prevents shaft overspeed and excessive core coolant mass flow rate. Researchers selected a large, dry pressurized water reactor (PWR) containment building that has a free volume of $70,000 \mathrm{~m}^{3}$ and a peak design pressure of 7 bar for this design based on a $100 \mathrm{in}^{2}$ cold duct break. During this same cold leg LOCA, the depressurization time was in excess of 10 minutes. No action needed to be taken by the SCS/ECS blowers before this time to prevent core damage. After this time, a total blower power less than $90 \mathrm{~kW}$ is sufficient to cool the core out to 10,000 seconds. A loss of flow transient in which a primary loop is instantaneously 
isolated and no mitigating action is taken (i.e., no reactor scram) is also shown not to cause core damage.

Researchers concluded that a large S-CO -cooled GFR coupled to a supercritical Brayton power conversion system can withstand the thermal hydraulic challenges posed by the usual menu of severe accident scenarios.

The final major development was devising an approach for optimally coupling the supercritical $\mathrm{CO}_{2}$-cooled GFR to a high-temperature steam electrolysis (HTSE) plant for hydrogen production. This involves the use of four parallel self-powered loops, each removing about 2.5 percent of reactor thermal power. The steam discharged from the loop's high-pressure turbine normally flows to the HTSE cell via recuperators, which recover thermal energy from the product hydrogen and oxygen gases. This allows the cell to operate at a higher temperature than the reactor, sustained by the ohmic heating produced by the electricity supplied by the reactor's large power conversion loops.

In normal operation and most shutdown scenarios, the turbine drives the $\mathrm{CO}_{2}$ loop circulator and generates excess electricity for plant or emergency system use. The reversible motor-generator can also power the blower using on- or off-site emergency electric power. This arrangement has several advantages. The water boiler loops eliminate the need for separate shutdown and emergency cooling loops and are always on, which increases the probability that they will be available for SCS/ECS service (no failto-start sequences and constant diagnostic signals). The loops are oversized for SCS/ECS service with a required total water boiler energy rating that allows for four 100 percent capacity shutdown cooling system loops, versus the four 50 percent loops specified in the current allelectric design. This yields a major improvement in safety assurance. Although devised for a GFR, the same approach will work for other Generation IV reactor concepts.

\section{Planned Activities}

Following is a summary of activities planned for the next fiscal year.

- Continue RELAP5-3D transient thermal hydraulic analyses to confirm the capability of the overall plant design to tolerate severe transient events, such as loss of coolant, flow, or load.

- Optimize a pin-type core design and finalize downselection between pin and tube-in-duct designs. Also assess minor actinide burning.

- Continue probabilistic risk assessment studies to help determine the best balance between passive and active safety assurance features and capabilities.

- Devise a final balance-of-plant direct cycle arrangement for the supercritical power conversion system, taking into account the experience developed under a separate Generation IV contract for indirect cycle analyses. This will serve as the basis for an updated, overall cost-of-electricity estimate. 


\title{
NUCLEAR ENERGY RESEARCH INITIATIVE
}

\author{
Optimized, Competitive Supercritical- $\mathrm{CO}_{2}$ Cycle for Generation IV Service
}

PI: Michael J. Driscoll, Massachusetts

Institute of Technology (MIT)

Collaborators: None
Project Number: $05-044$

Project Start Date: April 2005

Project End Date: April 2008

\section{Research Objectives}

This project is developing an integrated overall plant design for a gas-cooled fast reactor (GFR) based on the compact and highly efficient, direct supercritical carbon dioxide $\left(\mathrm{S}-\mathrm{CO}_{2}\right)$ Brayton cycle, which is under development for Generation IV service. This plant will be capable of economical electric power generation, high uranium utilization, burning of transuranics (TRU) and/or minor actinides (MAs), and hydrogen production through the high-temperature electrolysis of steam. Researchers are evaluating prospective plant designs using both the existing deterministic regulations and proposed risk-informed licensing framework. They are applying probabilistic techniques to optimize the tradeoffs between economics and safety assurance.

Most worldwide research on this type of gas reactor is presently based on a helium cycle that operates at temperatures approaching $900^{\circ} \mathrm{C}$, which poses severe challenges to the core and component materials. Because the $\mathrm{S}-\mathrm{CO}_{2}$ cycle can achieve high thermodynamic efficiency (approximately 44 to 51 percent) at more modest temperatures of 550 to $650^{\circ} \mathrm{C}$, researchers can utilize already-proven technologies in their design.

Major tasks of this project focus on designing the reactor core and decay heat removal systems. In designing the core, researchers have optimized features of the vented fuel concept using tube-in-duct (TID) assemblies (see Figure 1). In addition, they are evaluating a pin-type core design as an alternative and are confirming the capability of burning TRU and MAs. Design of the safety system is guided by probabilistic methods and involves deveioping a decay heat removal system for accidents, shutdown, and refueling; improving emergency power capabilities, such as microturbines or fuel cells; and integrating both active and passive means of shutdown assurance to preclude an

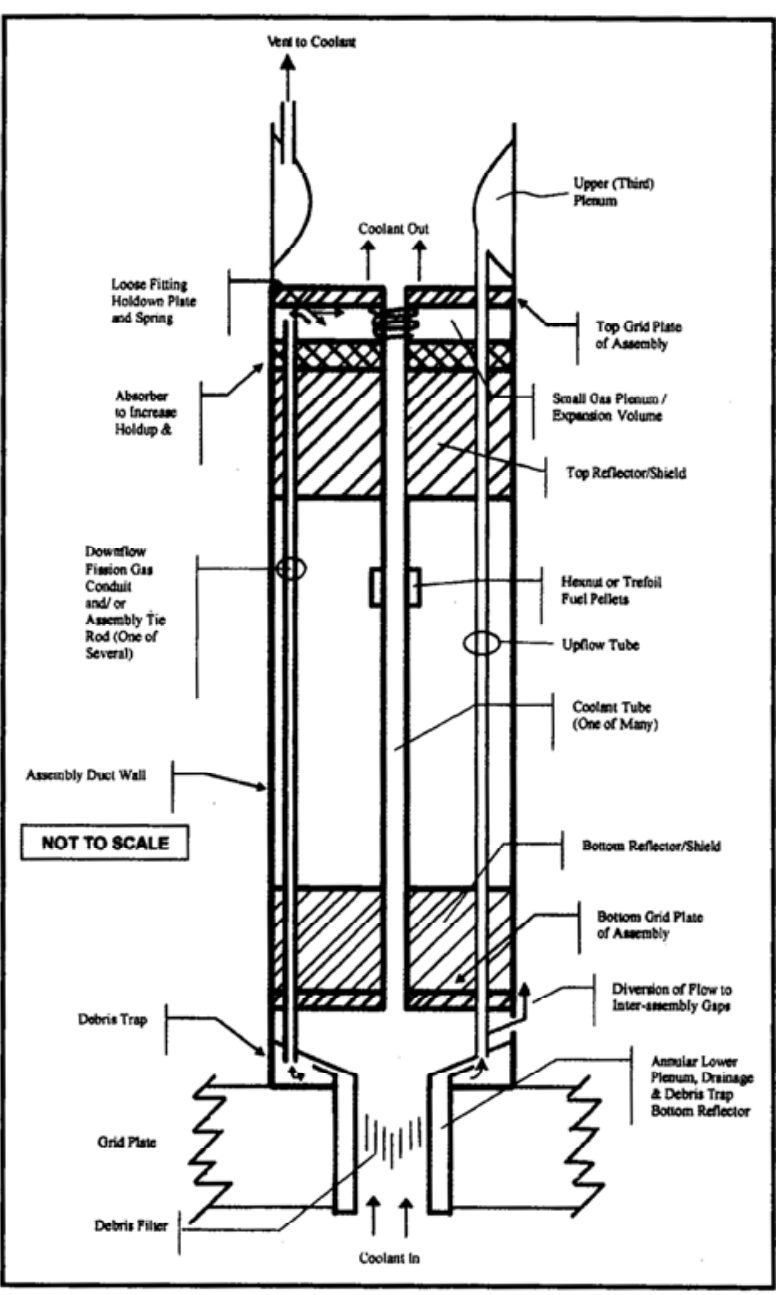

Figure 1. Vertical cross-section view of TID fuel assembly features.

anticipated transient without scram (ATWS). Researchers will also develop a reactor version for integration with a high-temperature steam electrolysis (HTSE) process 


\begin{tabular}{|c|c|c|}
\hline Subsystem & Features & Comments \\
\hline \multicolumn{3}{|l|}{ Core } \\
\hline Fuel & $\mathrm{UO}_{2}+\mathrm{BeO}$ & LWR TRU fissile \pm MA \\
\hline Clad & ODS-MA956, or HT-9 & $\mathrm{SiC}$ a long-range possibility \\
\hline Configuration & $\begin{array}{l}\text { Tube-in-duct fuel assemblies, trefoil or } \\
\text { "hexnut" pellets, vented, orificed }\end{array}$ & $\begin{array}{l}\text { Pin-type core as fallback is not up } \\
\text { to task }\end{array}$ \\
\hline Thermal-Hydraulics & $\begin{array}{l}\text { Axial peaking factor } \leq 1.3 \\
\text { Radial peaking factor } \leq 1.2 \\
\text { Power density } \sim 85 \mathrm{~W} / \mathrm{cc}\end{array}$ & $\begin{array}{l}\text { Vary BeO fraction to flatten power } \\
\text { lower than GA GCFR of } 1970 \text { s @ } \\
235 \text { W/cc }\end{array}$ \\
\hline Burnup & $\geq 120 \mathrm{MWd} / \mathrm{kg}$ (avg) & $\begin{array}{l}\text { In single batch no-reshuffle core, } \\
17-y r \text { lifetime }\end{array}$ \\
\hline \multicolumn{3}{|l|}{ Safety Systems } \\
\hline Auxiliary Loops & $\begin{array}{l}\text { Combined shutdown \& emergency, } \\
4 \times 50 \% \text { capable, active forced } \\
\text { convection; } \\
\text { Passive natural convection } \\
\text { supplemented; } \\
\text { Water boiler heat sink } \\
\end{array}$ & $\begin{array}{l}\text { Based on RELAP parallel loop } \\
\text { calculations. For } \mathrm{P} \geq 0.7 \mathrm{MPa} \text {, } \\
\text { natural convection alone may } \\
\text { suffice }\end{array}$ \\
\hline Emergency Power & Fuel cells to supplement diesels & $\begin{array}{l}\text { Projected to be more reliable than } \\
\text { diesels alone in long run }\end{array}$ \\
\hline \multicolumn{3}{|l|}{ Plant } \\
\hline $\begin{array}{l}\text { Power Conversion } \\
\text { System (PCS) }\end{array}$ & $\begin{array}{l}\text { Supercritical } \mathrm{CO}_{2} \text { Brayton direct } \\
2 \times 600 \mathrm{MWe} \text { loops }=1200 \mathrm{MWe} \text {; } \\
650^{\circ} \mathrm{C} \text { core exit/turbine inlet, } \\
20 \mathrm{MPa} \text { pressure }\end{array}$ & $\begin{array}{l}\text { AGRs in UK use } \mathrm{CO}_{2} \text { coolant at } \\
4 \mathrm{MPa} \text { and have } \mathrm{T} \sim 650^{\circ} \mathrm{C}\end{array}$ \\
\hline Reactor Vessel & $\begin{array}{l}\text { PCIV (prestressed cast iron } \\
\text { reactor vessel) }\end{array}$ & $\begin{array}{l}\text { Vessel houses loop isolation } \\
\text { and check valves plus shutdown } \\
\text { cooling heat exchangers }\end{array}$ \\
\hline Containment & $\begin{array}{l}\text { PWR type, steel liner reinforced } \\
\text { concrete } 0.7 \mathrm{MPa} \text { design capability } \\
70,000 \mathrm{~m}^{3} \text { free volume filtered/vented }\end{array}$ & $\begin{array}{l}\text { Internally insulated and } \mathrm{CO}_{2} \text { can } \\
\text { be added to keep pressure up to } \\
\text { natural convection needs }\end{array}$ \\
\hline $\begin{array}{l}\mathrm{H}_{2} \text { production by steam } \\
\text { electrolysis (optional) }\end{array}$ & $\begin{array}{l}4 \text { separate water boiler loops at } 10 \% \text { of } \\
\text { reactor power; } \\
\text { Recuperation of } \mathrm{H}_{2} \& \mathrm{O}_{2} \text { heat allows cell } \\
\text { operation at } 850^{\circ} \mathrm{C}\end{array}$ & $\begin{array}{l}\text { Water boiler loops can also serve } \\
\text { for self-powered decay heat } \\
\text { removal }\end{array}$ \\
\hline
\end{tabular}

Table 1. Current status of GFR plant features.

for hydrogen production and will conduct an economic assessment to estimate costs. Overall, this project will provide a sufficient basis for assessing this type of GFR among the other candidate Generation IV designs being evaluated for final selection.

\section{Research Progress}

Following is a summary of major tasks that were completed during the past year. Table 1 summarizes the current status of the plant design, incorporating all evolutionary changes since project initiation.

Most core physics, thermal-hydraulics, and fuel cycle activities are now complete. The reference design is based on the use of TID assemblies, which invert the usual pin configuration to put the uranium dioxide $\left(\mathrm{UO}_{2}\right)$ fuel outside coolant tubes. This permits high fuel volume fractions, which enable attaining a self-sustainable conversion ratio of unity with $\mathrm{UO}_{2}$ fuel. Adding beryllium oxide $(\mathrm{BeO})$ diluents 
to the fuel and using radial reflector assemblies having a $\mathrm{CO}_{2}$-only zone result in a negative coolant void reactivity-a rarity in fast reactors. The core has also been shown to have a favorable combination of reactivity feedback mechanisms (in the analytic integral fast reactor [IFR] quasi-static sense), which was confirmed using RELAP numerical simulation, providing self-protection during most severe transients including ATWS. Pin-type designs with $\mathrm{UO}_{2}$ fuel were also developed and evaluated and were found to have significantly inferior performance; therefore, they are not recommended for implementation. MA burning in fertile-free fuel was found to be possible and not inferior to other fast reactors, but again is not an attractive option.

The researchers have devised a GFR-supercritical $\mathrm{CO}_{2}$ Brayton cycle combination that is tailored to produce hydrogen by high temperature steam electrolysis. The system layout recuperates enough energy from the hydrogen and oxygen products to heat steam to the required electrolysis cell operating temperature of $850^{\circ} \mathrm{C}$, making it possible to keep the reactor core outlet temperature at or below $650^{\circ} \mathrm{C}$. The approach is, in principle, applicable to most other reactors. The GFR has four water boiler loops in parallel with the $\mathrm{CO}_{2}$ power conversion systems to produce the steam feed for the electrolysis cells. These loops also play the role of a highly effective decay heat removal system.

A combination of probabilistic risk assessment (PRA)guided design and RELAP5-3D loss of coolant accident (LOCA) simulation of parallel loop layouts has led to reliance on active, blower-driven decay heat removal loops which can also function, if necessary, in a backup passive natural circulation mode. This decision was driven by the finding that unaided natural convection loops can experience startup phase flow reversal, which can lead to core coolant bypass. Check valve leakage beforehand as well as the failure to open under the small pressure differentials in a gas circuit are the dominant causative factors. The conditional failure probability of the decay heat removal system (given a LOCA) was unacceptably high even after some design modifications. This task has also served as the MIT contribution to an I-NERI collaboration with the French Commissariat à l'énergie atomique (CEA) that has followed a similar evolutionary path in designing post-accident decay heat removal systems for a heliumcooled GFR.
The major new activity has been to start on a more detailed design and performance analysis of the fuel venting system needed to equalize gas pressure across the coolant tubes and fuel assembly duct walls with that of the primary coolant. By making the escape path for fission product noble gases long enough (and with several plena interspersed), releases are sufficiently suppressed to allow venting into the primary coolant system rather than into a collection plenum built into the core grid structure, as originally conceptualized. A stage-by-stage analysis of fission product transport is in progress: from the fuel to vent system, to the coolant, to the containment atmosphere, and finally to the environs. Initial results are encouraging with respect to protection of both plant personnel and the general public.

\section{Planned Activities}

Work is concentrated on four major remaining subtasks in the upcoming year:

- Complete evaluation of the advanced version of the vented fuel assembly design to confirm that primary system, in-containment, and off-site fission product inventories, deposition, and releases are tolerable

- Complete PRA and decay heat removal system studies, focusing on achieving a negligible likelihood of suffering an ATWS event by incorporating a diverse, redundant suite of active and passive reactivity insertion means

- Complete plant and fuel cycle cost estimates to provide busbar cost of electricity values relative to the Gen III and Gen IV reactor competition

- Draft a final summary report 


\section{Appendix B GFR Project Publications as of 8/31/08}

\section{Bibliography of MIT GFR Publications}

In the interest of completeness, this list includes all topical reports, journal publications and meeting transactions published as a product of coordinated GFR projects at MIT since the year 2000, through summer 2008, at which point all GFR efforts were completed.

This compilation does not include the monthly/quarterly/annual reports routinely generated in the course of these projects. The information in such reports is, in general, published in a more complete and thoroughly interpreted form in the reports listed here.

\section{Conference Transactions and Journal Articles}

1. P. Hejzlar, M.J. Driscoll, N.E. Todreas, A Modular Gas Turbine Fast Reactor Concept (MFGR-GT), Trans. Am. Nucl. Soc., Vol. 84, p.242, Milwaukee WI, June 17-21, 2001

2. V. Dostal, P. Hejzlar, M.J. Driscoll, N.E. Todreas, A Supercritical $\mathbf{C O}_{2}$ Brayton Cycle for Advanced Reactor Applications, Trans. Am. Nucl. Soc., Vol. 85, p.110, Reno NV, November 11-15, 2001

3. K. Yu, M.J. Driscoll, P. Hejzlar, Neutronic Limits of Breed and Burn Fast Reactor Performance, Trans. Am. Nucl. Soc., Vol. 86, p.335-336, Hollywood FL, June 9-13, 2002.

4. M.J. Driscoll, P. Hejzlar, N.E. Todreas, Fuel-In-Thimble GCFR Concepts for GEN-IV Service, ICAPP ‘02, Hollywood, FL, June 9-13, 2002.

5. P. Hejzlar, M.J. Driscoll, N.E. Todreas, The Long-Life Gas Turbine Fast Reactor Matrix Core Concept, ICAPP '02, Hollywood FL, June 9-13, 2002

6. Y. Okano, P. Hejzlar, N.E. Todreas, M.J. Driscoll, Thermal-Hydraulics and Post-Shutdown Cooling of a $\mathbf{C O}_{2}$-Cooled, Gas Turbine Fast Reactor, Trans. Am. Nucl. Soc., Vol. 86, p.139-141, Hollywood FL, June 9-13, 2002.

7. V. Dostal, P. Hejzlar, M.J. Driscoll, N.E. Todreas, A Supercritical $\mathbf{C O}_{2}$ Gas Turbine Power Cycle for Next Generation Nuclear Reactors, ICONE 10, $10^{\text {th }}$ International Conference on Nuclear Engineering, Arlington VA, April 14$18,2002$.

8. K. Yu, M.J. Driscoll, P. Hejzlar, Neutronic Screening of Diluents for GCFR Fuel, Trans. Am. Nucl. Soc., Vol. 87, p.386-387, Washington, D.C., November 17-21, 2002.

9. V. Dostal, P. Hejzlar, M.J. Driscoll, N.E. Todreas, Component Design for a Supercritical $\mathrm{CO}_{2}$ Brayton Cycle, Trans. Am. Nucl. Soc., Vol. 87, p.536-537, Washington D.C., November 17-21, 2002. 
10. V. Dostal, P. Hejzlar, M.J. Driscoll, N.E. Todreas, Realism in Brayton Cycle Calculations, Trans. Am. Nucl. Soc., Vol. 87, p.534-535, Washington D.C., November 17-21, 2002.

11. K. Yu M.J. Driscoll, P.J. Yarsky, M.A. Pope, P. Hejzlar, Comparison of GFR Core Reflectors, Trans. Am. Nucl. Soc., Vol. 88, p.520-523, San Diego CA, June 1-5, 2003

12. M.J. Driscoll. P. Hejzlar, Active or Passive Post-LOCA Cooling of GFRs?, Trans. Am. Nucl. Soc., Vol. 88, p.673-677, San Diego CA, June 1-5, 2003

13. M.J. Driscoll, P. Hejzlar, K.D. Weaver. M.K. Meyer, Basic Design Choices for a Breed and Burn Fast Reactor, Trans. Am. Nucl. Soc., Vol. 88, p.678-680, San Diego CA, June 1-5, 2003

14. W-J. Lee, B-D. Chung, Y-J. Lee, J-H. Chang, P. Hejzlar, M.J. Driscoll, Development of MARS-GCR for Gas Cooled Reactor Analysis Incorporation of Gas Properties The 10th International Topical Meeting on Nuclear Reactor Thermal Hydraulics (NURETH-10) Seoul, Korea, October 511,2003

15. M.A. Pope, M.J. Driscoll, P. Hejzlar, Reactor Physics Studies in Support of GFR Core Design, Proc. of GLOBAL '03, New Orleans, LA, Nov. 16-21, 2003

16. M.J. Driscoll, M.A. Pope, P. Hejzlar, Device for Passive Reactivity Insertion During GFR LOCA, Trans. Am. Nucl. Soc., 2003 Winter Meeting, Vol. 89, p.578-579, New Orleans, LA, Nov. 16-21, 2003

17. M.J. Driscoll, M.A. Pope, P. Hejzlar, Self-Actuated Reactivity Insertion Device for GFR Service, Trans. Am. Nucl. Soc., 2003 Winter Meeting, Vol. 89, p.573-575, New Orleans, LA, Nov. 16-21, 2003

18. N.A. Carstens, M.J. Driscoll, LOCA-Powered SCRAM Device for GFRs, Trans. Am. Nucl. Soc., 2003 Winter Meeting, Vol. 89, p.576-577, New Orleans, LA, Nov. 16-21, 2003

19. Y. Wang, V. Dostal, P. Hejzlar, Turbine Design for Supercritical $\mathbf{C O}_{2}$ Brayton Cycle, Proc. of GLOBAL '03, New Orleans, LA, Nov. 16-21, 2003

20. W.C. Williams, P. Hejzlar, P. Saha, Analysis of a Convection Loop for GFR Post-LOCA Decay Heat Removal, Proc. of ICONE 12, April 25-29, Arlington, VA, 2004

21. M.J. Delaney, G.E. Apostolakis, A Probabilistic Analysis of General Design Criterion 35 for a Gas-Cooled Fast Reactor, Proc. of ICAPP '04, Pittsburgh, PA, Vol. 90, June 13-17, 2004

22. P.J. Yarsky, M.J. Driscoll, P. Hejzlar, Neutronic Studies of Nuclear Fuels for a Breed and Burn GFR, Proc. of ICAPP '04, Pittsburgh, PA, June 13-17, 2004

23. W.C. Williams, P. Hejzlar, M.J. Driscoll, Decay Heat Removal from a GFR Core by Natural Convection, Proc. of ICAPP '04, Pittsburgh, PA, June 13-17, 2004 
24. M.J. Driscoll, P. Hejzlar, M.J. Delaney, W. C. Williams, C. Matos, Compressed Gas Emergency Power Supply for GFR Service, Trans. Am. Nucl. Soc., Pittsburgh, PA, Vol. 90, June 13-17, 2004

25. P.J. Yarsky, M.J. Driscoll, P. Hejzlar, Use of Minimally Processed Fast Reactor Fuel in Light Water Reactors, Trans. Am. Nucl. Soc., Pittsburgh, PA, Vol. 90, June 13-17, 2004

26. V. Dostal, M.J. Driscoll, P. Hejzlar, Y. Wang, Supercritical $\mathbf{C O}_{2}$ Cycle for Fast Gas-Cooled Reactors, Proc. of ASME TurboExpo, Vienna, Austria, June 2004

27. Y. Wang, G.R.Guenette, P. Hejzar, M.J. Driscoll, Compressor Design for the Supercritical $\mathrm{CO}_{2}$ Brayton Cycle, Proc. of $2^{\text {nd }}$ Int. Energy Conversion Engineering Conference (IECEC), Providence RI, 16-19 Aug. 2004

28. P. Hejzlar, M.J. Pope, W.C. Williams, M.J. Driscoll, Gas Cooled Fast Reactor for Generation IV Service, Progress in Nuclear Energy, Innovative Nuclear Energy Systems for Sustainable Development of the World, Tokyo, Japan, Vol., 47, No. 1-4, pp. 271-282, (Pub. 2005) Oct. 31-Nov. 4, 2004

29. M.A. Pope, M.J. Driscoll, P. Hejzlar, Coolant Void Reactivity in Supercritical $\mathbf{C O}_{2}$-Cooled Fast Reactors, Trans. Am. Nucl. Soc., Washington, DC, Vol. 91, pp. 740-742, Nov. 14-18, 2004

30. P. Hejzlar, W.C. Williams, M.J. Driscoll, Hot Channel Flow Starvation of Helium Cooled GFRs in Laminar Natural Convection, Trans. Am. Nucl. Soc., Washington, DC, Vol. 91, pp. 202-204, Nov. 14-18, 2004

31. P.J. Yarsky, M.J. Driscoll, P. Hejzlar, Design of a Once-Through Breed and Burn GFR, Trans. Am. Nucl. Soc., Washington, DC, Vol. 91, pp. 753-755, Nov. 14-18, 2004

32. L.P. Pagani, G.E. Apostolakis, P. Hejzlar, The Impact of Uncertainties on the Performance of Passive Systems, Nucl. Tech., Vol., 149 No. 2, pp. 129-140, February 2005

33. M.J. Driscoll, P. Hejzlar, Reactor Physics Challenges in GEN-IV Reactor Design, Nucl. Eng. \& Tech., Vol. 37, No. 1, February 2005

34. M.J. Delaney, G.E. Apostolakis, M.J. Driscoll, Risk-Informed Design Guidance for Future Reactor Systems, Nucl. Eng. and Design, Vol. 235, May 2005

35. P. Hejzlar, V. Dostal, M.J. Driscoll, P. Dumaz, G. Poullennec, N. Alpy, Assessment of Gas Cooled Fast Reactor with Indirect Supercritical $\mathbf{C O}_{2}$ Cycle, ICAPP '05, Paper 5090, Seoul, Korea, May 15-19, 2005

36. P.J. Yarsky, P. Hejzlar, M.J. Driscoll, Reactor Physics Studies of a Breed and Burn Gas-cooled Fast Reactor, ICAPP '05, Paper 5030, Seoul, Korea, May $15-19,2005$ 
37. T. Wei, P. Hejzlar, E.E. Feldman, W.C. Williams, A Semi-Passive Approach to GFR Depressurized Decay Heat Removal Accidents, ICAPP '05, Paper 5007, Seoul, Korea, May 15-19, 2005

38. M.A. Pope, P.J. Yarsky, M.J. Driscoll, P. Hejzlar, P. Saha, An Advanced Vented Fuel Assembly Design for GFR Applications, Trans. Am. Nucl. Soc., Vol. 92, p.211, San Diego, CA, USA, June 5-9, 2005

39. P.J. Yarsky, M.A. Pope, M.J. Driscoll, P. Hejzlar, Reactor Physics Analysis of a Tube-in-Duct Fuel Design for GFR Service, Trans. Am. Nucl. Soc., Vol. 92, p.694, San Diego, CA, USA, June 5-9, 2005

40. C.S. Handwerk, M.J. Driscoll, P. Hejzlar, P.J. Yarsky, M.A. Pope, Power Shaping of a Long-Lived GFR Core Using Diluents, Trans. Am. Nucl. Soc., Vol. 93, p.115, Washington D.C., USA, November 13-17, 2005

41. D. Akkaynak, M.J. Driscoll, P. Hejzlar, G. E. Apostolakis, M. W. Golay, E. G. Cravalho, Use of Fuel Cells to Power a High-Reliability GFR ECCS, Trans. Am. Nucl. Soc., Vol. 93, p.292, Washington D.C., USA, November 13-17, 2005

42. M.A. Pope, M.J. Driscoll, P. Hejzlar, Shutdown / Emergency Cooling System For A $2400 \mathbf{M W}_{\mathrm{TH}}$ Supercritical $\mathbf{C O}_{2}$-Cooled Direct-Cycle GFR, ICAPP '06, Paper 6097, Reno, NV, June 4-8, 2006

43. V. Dostal, P. Hejzlar, M.J. Driscoll, High Performance Supercritical Carbon Dioxide Cycle for Next Generation Reactors, ICAPP '06, Paper 6307, Reno, NV, June 4-8, 2006

44. V. Dostal, P. Hejzlar, M.J. Driscoll, High Performance Supercritical Carbon Dioxide Cycle for Next Generation Nuclear Reactors, Nuclear Technology, Vol. 154, No. 3, June 2006

45. V. Dostal, P. Hejzlar, M.J. Driscoll, The Supercritical Carbon Dioxide Power Cycle: Comparison to Other Advanced Power Cycles, Nuclear Technology, Vol. 154, No. 3, June 2006

46. C.S. Handwerk, M.J. Driscoll, P. Hejzlar, Use of Beryllium Oxide to Shape Power and Reduce Void Reactivity in Gas Cooled Fast Reactors, PHYSOR 2006, Vancouver, Sept. 2006

47. M.J. Driscoll and C.S. Handwerk, Tests of a Flow-Levitated Absorber for GFR LOF and LOCA Mitigation, Trans. ANS, Vol. 94, June 2006

48. M.J. Memmott, M.J. Driscoll, P. Hejzlar, Synergistic Configuration of a GFR for Hydrogen Production by Steam Electrolysis, Trans. ANS, Vol. 95, Nov. 2006

49. D.M. Legault, P. Hejzlar, M.J. Driscoll, Effect of Pressure Drop in Brayton Cycle Efficiency Calculations, Trans. ANS, Vol. 95, Nov. 2006

50. C.S. Handwerk, M.J. Driscoll, P. Hejzlar, Comparison of Tube-in-Duct and Pin Fuel for $\mathrm{S}_{-} \mathrm{CO}_{2}$ Cooled Fast Reactor Applications, Trans. Am. Nucl. Soc., Vol. 96, June 2007 
51. F.J. Mackay, G.E. Apostolakis, P. Hejzlar, Calculating the Unreliability of a Passive System, Trans. Am. Nucl. Soc., Vol. 96, June 2007

52. J.P. Gibbs, P. Hejzlar, Y. Gong, M.J. Driscoll, Plant Layout for a 1200 MWe Direct Brayton Cycle GFR, Trans. Am. Nucl. Soc., Vol. 96, June 2007

53. F.J. Mackay, G.E. Apostolakis, P. Hejzlar, Incorporating Reliability Analysis into the Design of Passive Cooling Systems with an Application to a GasCooled Reactor, Nuclear Engineering and Design, Vol. 238, pp.217-228, 2008

54. G. Patalano, G.E. Apostolakis, P. Hejzlar, Risk-Informed Design Changes in a Passive Decay Heat Removal System, Accepted for Publication in Nuclear Technology

55. C.S. Handwerk, M.J. Driscoll, P. Hejzlar, Optimized Core Design of a Supercritical Carbon Dioxide-Cooled Fast Reactor, Scheduled for Publication in Nuclear Technology, December 2008

56. N.A. Carstens, P. Hejzlar, R.B. Vilim, M.J. Driscoll, Inventory Control for the S-CO ${ }_{2}$ Recompression Cycle, Trans. Am. Nucl. Soc., Vol. 96, p.800, Boston, USA, June 24-28, 2007

57. J.I. Lee, P. Hejzlar, Experimental and Computational Analysis of Gas Natural Circulation Loop, Proc. International Congress on Advances in Nuclear Power Plants, ICAPP '07, Paper 7381, Nice, France, May 13-18, 2007

58. M.J. Driscoll, C.S. Handwerk, Multibatch Fuel Management for Gen IV Fast Reactors, Trans. Am. Nucl. Soc., Vol. 97, Nov. 2007

59. S.A. McKee, M.J. Driscoll, An Evaluation of Vented Gas Cooled Fast Reactor Fuel, Trans. Am. Nucl. Soc., Vol. 98, June 2008

\section{CANES MIT-ANP-TR and PR Series}

1. M.J. Driscoll, P. Hejzlar, N.E. Todreas, Y. Okano, V. Dostal, K. Yu, Development of Gen IV Advanced Gas-Cooled Reactors with Hardened/Fast Neutron Spectrum, Annual Progress Report, MIT-ANP-PR-093, September 2002

2. K. Yu, M.J. Driscoll, P. Hejzlar, Neutronic Evaluation of GCFR Core Diluents, MIT-ANP-TR-086, June 2003

3. M.J. Driscoll, P. Hejzlar, N.E. Todreas, B. Veto, Modern Gas-Cooled Fast Reactor Safety Assurance Considerations, MIT-ANP-TR-087, May 2003

4. Y. Okano, P. Hejzlar, N.E. Todreas, M.J. Driscoll, Thermal Hydraulics and Shutdown Cooling of Supercritical $\mathrm{CO}_{2}$ GT-GCFRs, MIT-ANP-TR-088, August 2002

5. V. Dostal, M.J. Driscoll, P. Hejzlar, N.E. Todreas, $\mathbf{C O}_{2}$ Brayton Cycle Design and Optimization MIT-ANP-TR-090, November 2002 
6. W.C. Williams, P. Hejzlar, M.J. Driscoll, W-J. Lee, P. Saha, Analysis of A Convection Loop for GFR Post - LOCA Decay Heat Removal from a BlockType Core, MIT-ANP-TR-095, March 2003

7. V. Dostal, M.J. Driscoll, P. Hejzlar, A Supercritical Carbon Dioxide Cycle for Next Generation Reactors, MIT-ANP-TR-100, March 10, 2004

8. K. Gezelius, M. J. Driscoll, P. Hejzlar, Design of Compact Intermediate Heat Exchangers for Gas Cooled Fast Reactors, MIT-ANP-TR-103, May 2004

9. M.A. Pope, M.J. Driscoll, P. Hejzlar, Reactor Physics Design of Supercritical $\mathbf{C O}_{2}$-Cooled Fast Reactors, MIT-ANP-TR-104, September 2004

10. G. Jourdan, M. W. Golay, Using Risk-Based Regulations for Licensing Nuclear Power Plants: Case Study of the Gas-cooled Fast Reactor, MITANP-TR-106, December 2005

11. P.J. Yarsky, M.J. Driscoll, P. Hejzlar, Integrated Design of a Breed and Burn Gas-Cooled Fast Reactor Core, MIT-ANP-TR-107, September 2005

12. M.A. Pope, P. Hejzlar, M.J. Driscoll, Thermal Hydraulics of a 2400 MWth Supercritical $\mathbf{C O}_{2}$-Direct Cycle GFR, MIT-ANP-TR-112, September 2006

13. M.J. Memmott, M.J. Driscoll, M.S. Kazimi, P. Hejzlar, Hydrogen Production by Steam Electrolysis Using a Supercritical $\mathbf{C O}_{2}$-Cooled Fast Reactor, MITNES-TR-007, Feb. 2007

14. C.S. Handwerk, P. Hejzlar, M.J. Driscoll, Core Design and Performance Assessment for a Supercritical $\mathbf{C O}_{2}$-Cooled Fast Reactor, MIT-ANP-TR-113, May 2007

15. J. Lee, P. Hejzlar, M.S. Kazimi, Deteriorated Turbulent Heat Transfer to UpFlowing Gas in a Heated Vertical Channel, MIT-ANP-TR-115, May 2007

16. M.J. Driscoll, Comparative Economic Prospects of the Supercritical $\mathbf{C O}_{2}$ Brayton Cycle GFR, MIT-ANP-TR-119, Feb. 2008

GFR Series, MIT-GFR-001 to MIT-GFR-044

1. S. Thon, Selection of Materials for a Supercritical $\mathbf{C O}_{2}$ Cooled GCFR, MIT-GFR-001, Aug. 2002

2. J. Eapen, Analysis of a Natural Convection Loop for Post-LOCA GCFR Decay Heat Removal, MIT-GFR-002, Dec. 2002

3. Y. Wang, Aerodynamic Design of Turbine for $\mathrm{S}_{-} \mathrm{CO}_{2}$ Brayton Cycle, MITGFR-003, June 2003

4. K. Gezelius, V. Dostal, M.J. Driscoll, P. Hejzlar, Design of Shell and Tube Heat Exchanger for the S- $\mathrm{CO}_{2}$ Cycle and Laminar Flow in Microchannel Heat Exchangers, MIT-GFR-004, May 2003 
5. P.J. Yarsky, Neutronic Evaluation of GFR Breed and Burn Fuels, MITGFR-005, May 2003

6. L. B. Fishkin, Prestressed Cast Iron Vessel (PCIV) Use for GEN-IV GFR Applications, MIT-GFR-006, April 2004

7. J. Plaue, K.R. Czerwinski, Evaluation of Uranium Carbide and Sulfide Fuels for a Gas-Cooled Fast Reactor Utilizing Dry Reprocessing, MITGFR-007, October 2003

8. M.J. Delaney, C. Matos, B.T. Parks, J.P. Koser, Interim Report on Task 1, GFR PRA-Guided Plant Design and Core Materials Compatibility Studies for $\mathrm{CO}_{2}$ Cooled Reactor, Annual Report on Project: Plant Design and Core Materials Compatibility Studies for Supercritical $\mathrm{CO}_{2}$ Cooled Reactors, MIT-GFR-008, March 2004

9. W.C. Williams, P. Hejzlar, P. Saha, M.J. Driscoll, Comparative Analysis of Decay Heat Removal Approaches for a Block GFR Core, MIT-GFR-009, February 2004

10. D. Rigual, P. Stahle, Y. Ostrovsky, Y.H. Jeong, R. Ballinger, Interim Report on Task 2: Loops for Corrosion Tests in Supercritical $\mathrm{CO}_{2}$ in the Presence of Radiolysis, Annual Report on Project: Plant Design and Core Materials Compatibility Studies for Supercritical $\mathrm{CO}_{2}$ Cooled Reactors, MIT-GFR-010, March 2004

11. J. Plaue, K. Czerwinski, Interim Report on Task 3: Fuel Material Interactions, Annual Report on Project: Plant Design and Core Materials Compatibility Studies for Supercritical $\mathrm{CO}_{2}$ Cooled Reactors, MIT-GFR-011, March 2004

12. Yong Wang, V. Dostal, M.J. Driscoll, P. Hejzlar G.R. Guenette, Qualification of the Supercritical $\mathrm{CO}_{2}$ Power Conversion Cycle for Advanced Reactor Applications, Annual / Topical Technical Progress Report, MIT-GFR-012, April 2004

13. M. Delaney, G.E. Apostolakis, M.J. Driscoll, Risk-Informed Design Guidance for a Generation-IV Gas-Cooled Fast Reactor Emergency Core Cooling System, MIT-GFR-013, May 2004

14. M.J. Driscoll, P. Hejzlar, 300 MWe Supercritical $\mathbf{C O}_{2}$ Plant Layout and Design, MIT-GFR-014, June 2004

15. Yong Wang, G.R. Guenette, P. Hejzlar, M.J. Driscoll, Supercritical CO $\mathbf{O}_{2}$ Turbine And Compressor Design, MIT-GFR-015, June 2004

16. Jonatan Hejzlar, Computer Code for the Analysis of Printed Circuit Heat Exchangers with Zigzag Channels, MIT-GFR-016, August 2004 
17. M.J. Driscoll, P. Hejzlar, N. Carstens, Yong Wang, Interim Topical Report, Simulation of Supercritical $\mathbf{C O}_{2}$ Brayton Cycle Plants, MIT-GFR-017, Sept. 2004

18. Yong Wang, M.J. Driscoll, P. Hejzlar, G. R. Guenette Interim Topical Report, Small Scale Supercritical $\mathrm{CO}_{2}$ Components and System for Laboratory Tests, MIT-GFR-018, Sept. 2004

19. M.J. Driscoll, Interim Topical Report, Supercritical $\mathbf{C O}_{2}$ Plant Cost Assessment, MIT-GFR-019, Sept. 2004

20. P. Stahle, J. Lee, P. Saha, P. Hejzlar, Annual Report, Design Of ThermalHydraulic Loop related to Advanced Gas-Cooled Reactor, MIT-GFR-020, Oct. 2004

21. M.J. Driscoll, P. Hejzlar, Final Report on LDRD Project, An Innovative GasCooled Fast Reactor, MIT-GFR-021 Sept. 2004

22. Yong Wang, G.R. Guenette. P. Hejzlar, M.J. Driscoll, Aerodynamic Design of Turbomachinery for $\mathbf{3 0 0}$ MWe Supercritical Carbon Dioxide Brayton Power Conversion System, MIT-GFR-022, March 2005

23. P. Cochran, P. Saha, P. Hejzlar, D. M. McEligot, G. E. McCreery, R.R. Schultz, Scaling Analysis and Selection of Test Facility for Fundamental Thermal-Hydraulic Studies related to Advanced Gas-Cooled Reactor, MIT-INEEL Report, INL/EXT-05-00158, MIT-GFR-023, September 2004

24. Craig Matos, Feasibility of Risk-Informed Regulation for Generation-IV Reactors, MIT-GFR-024, May 2005

25. P. W. Stahle, M.J. Driscoll, P. Hejzlar, Supercritical $\mathbf{C O}_{2}$ Power Conversion System Design and Layout for 300 MWe Plant, MIT-GFR025R, Sept. 15, 2005

26. P. Hejzlar, S. J. Kim, W. C. Williams, Transient ATHENA/RELAP-3D Calculations for a 600 MWth Plate-type Helium GFR, MIT-GFR-026, April 2005

27. N.A. Carstens, P. Hejzlar, M.J. Driscoll, Description of Supercritical $\mathbf{C O}_{2}$ Systems Control Model, MIT-GFR-027, Sept. 2005

28. Yifang Gong, N.A. Carstens, M.J. Driscoll, Supercritical $\mathbf{C O}_{2}$ Cycle Main Compressor Design and Analysis Studies, MIT-GFR-028, Sept. 2005

29. H. Funmilayo, M.J. Driscoll, Y. Gong, G. R. Guenette, Design of Small Scale Supercritical $\mathrm{CO}_{2}$ Brayton Cycle Experiment, Including Main Compressor Test Capability, MIT-GFR-029, August 15, 2005

30. N. A. Carstens, Props 1.5: A Command Line Fluid Properties Code, MITGFR-030, August 2005

31. N. A. Carstens, Turbomap 1.2: A Command Line Turbomachinery Map Code, MIT-GFR-031, Sept. 2005 
32. Yunzhi Wang, Estimation of N-16 Dose Rate for Direct Cycle $\mathbf{C O}_{2}$ Gas Cooled Fast Reactors, MIT-GFR-032, August 2005

33. J. Lee, P. Hejzlar, P. Stahle, P. Saha, Design of Thermal-Hydraulic Loop Related to Advanced Gas-Cooled Reactor, MIT-GFR-033, Sept. 2005

34. G. R. Guenette, Y. Gong, Analysis of S- $\mathrm{CO}_{2}$ Small Scale Main Compressor Options for Laboratory Testing, MIT-GFR-034, Sept. 2005

35. M.J. Driscoll, P. Hejzlar et al, Engineering and Physics Optimization of Breed and Burn Fast Reactor Systems, NERI Final Report, MIT-GFR-035, Dec. 2005

36. D.M. Legault, P. Hejzlar, CYCLES II: A Steady State Code for Supercritical $\mathrm{CO}_{2}$ Power Conversion System Calculations, MIT-GFR-036, June 2006

37. J.P. Gibbs, P. Hejzlar, M.J. Driscoll, Applicability of Supercritical $\mathbf{C O}_{2}$ Power Conversion Systems to GEN IV Reactors, MIT-GFR-037, Sept. 15, 2006

38. N.A. Carstens, P. Hejzlar, M.J. Driscoll, Control System Strategies and Dynamic Response for Supercritical $\mathrm{CO}_{2}$ Power Conversion Cycles, MITGFR-038, Sept. 15, 2006

39. S.S. Fernandez, A. Al Hajj-Ahmad, E. Bolukbasi, M.J. Driscoll, ExtendedScope Applications of the Supercritical $\mathrm{CO}_{2}$ Power Conversion System, MIT-GFR-039, Aug. 2006

40. D. Langewisch, S.-P. Kao, M.J. Driscoll, HXMOD - A Heat Exchanger Module for Power Cycle Dynamics Modelling, MIT-GFR-040, Aug. 2006

41. I.A. Matthews, Characterization of Radial Compressors for Supercritical $\mathbf{C O}_{2}$ Power Conversion Systems, MIT-GFR-041, Sept. 2006

42. J. Lee, P. Hejzlar et al., Investigation of Fundamental Thermal-Hydraulic Phenomena in Advanced Gas-Cooled Reactors, MIT-GFR-042, Sept. 2006 (superseded by MIT-ANP-TR-115)

43. S.A. McKee, Assessment of Fuel Assembly Venting for Supercritical $\mathrm{CO}_{2}$ Cooled Fast Reactors, MIT-GFR-043, May 2008

44. Nuclear Energy Research Initiative (NERI), Cumulative Compilation of Quarterly Reports, April 2005 - September 2008 (Available in CD Version Only), MIT-GFR-044, Aug. 2008

45. Nuclear Energy Research Initiative (NERI), Optimized, Competitive Supercritical-CO $\mathrm{C}_{2}$ Cycle for Gen IV Service: Final Report, April 2005 August 2008. MIT-GFR-045, August 2008 


\section{INERI Reports}

1. T.Y.C. Wei, J. Roualt, eds, P. Hejzlar, contributor, Development of Generation IV Advanced Gas-Cooled Reactors with Hardened/Fast Neutron Spectrum, $3^{\text {rd }}$ Annual INERI Progress Report, Project \# 2001-002-F, October 2004

2. T.Y.C. Wei, J. Roualt, eds, P. Hejzlar, contributor, Development of Generation IV Advanced Gas-Cooled Reactors with Hardened/Fast Neutron Spectrum, $2^{\text {rd }}$ Annual INERI Progress Report, Project \# 2001-002-F, October 2003

3. T.Y.C. Wei, J. Roualt, eds, P. Hejzlar, contributor, Development of Generation IV Advanced Gas-Cooled Reactors with Hardened/Fast Neutron Spectrum, 1st Annual INERI Progress Report, Project \# 2001-002-F, October 2002

4. P. Hejzlar et al: CEA-Cadarache, Argonne National Lab, CEA-Saclay, Brookhaven National Lab, General Atomics, MIT, Development of Generation IV Advanced Gas-Cooled Reactors with Hardened/Fast Neutron Spectrum, System Report, International Nuclear Energy Research Initiative \#2001-002F, February 2005

\section{GFR Theses}

1. Jonathan Plaue, Evaluation of Uranium Carbide and Sulfide Fuels for a Gas-Cooled Fast Reactor Utilizing Dry Reprocessing, SM Thesis, MIT Nucl. Eng. Dept., June 2003

2. Kun $\mathrm{Yu}$, Neutronic Evaluation of GCFR Core Diluents and Reflectors, SM Thesis, MIT Nucl. Eng. Dept., July, 2003

3. Vacek Dostal, A Supercritical Carbon Dioxide Cycle for Next Generation Reactors, ScD Thesis, MIT Nucl. Eng. Dept., January 2004

4. Knut Gezelius, Design of Compact Intermediate Heat Exchangers for Gas Cooled Fast Reactors, SM/SB Thesis, MIT Nucl. Eng. Dept., May 2004

5. Michael Pope. Reactor Physics Design of Supercritical $\mathrm{CO}_{2}$-Cooled Fast Reactors, SM Thesis, MIT Nucl. Eng. Dept., September 2004

6. Gregoire Jourdan, Using Risk-Based Regulations for Licensing Nuclear Power Plants: Case Study of the Gas-Cooled Fast Reactor, SM Thesis, MIT Nucl. Eng. Dept., February 2005

7. Michael J. Delaney, Design Guidance of a Generation-IV Gas-Cooled Fast Reactor Emergency Core Cooling System, SM Thesis, MIT Nucl. Eng. Dept., April 2005

8. Craig Matos, Feasibility of Risk-Informed Regulation for Generation-IV Reactors, SM Thesis, MIT Nucl. Eng. Dept., June 2005 
9. Matthew Hine, Design of Experiment for Thermal-Hydraulic Measurements on Wavy Heat Exchanger Channels, SB Thesis, MIT Nucl. Eng. Dept., June 2005

10. Derya Akkaynak, Use of Fuel Cells for Improving On-Site Emergency Power Availability and Reliability at Nuclear Power Plants, SM Thesis, MIT Dept. of Aeronautics and Astronautics, June 2005

11. Peter Yarsky, Core Design and Reactor Physics of a Breed and Burn GasCooled Fast Reactor, PhD Thesis, MIT Nucl. Eng. Dept., Sept. 2005

12. David M. Legault, Development and Application of a Steady State Code for Supercritical Carbon Dioxide Cycles, SB Thesis, MIT Dept. of Nuclear Science \& Engineering, June 2006

13. Michael A. Pope, Thermal Hydraulic Design of a 2400 MWth Direct Supercritical $\mathbf{C O}_{2}$-Cooled Fast Reactor, PhD Thesis, MIT Dept. of Nuclear Science and Engineering, Sept. 2006

14. M.J. Memmott, Hydrogen Production Using a Supercritical $\mathbf{C O}_{2}$-Cooled Fast Reactor and Steam Electrolysis, SM Thesis, MIT Dept. of Nuclear Science and Engineering, Feb. 2007

15. C.S. Handwerk, Optimized Core Design of a Supercritical Carbon Dioxide Cooled Fast Reactor, PhD Thesis, MIT Dept. of Nuclear Science and Engineering, May 2007

16. F.J. Mackay, Calculating Failure Probabilities of Passive Systems During Transients, SM Thesis, MIT Dept. of Nuclear Science and Engineering, Jan. 2007

17. G. Patalano, Risk-Informed Design Changes for a Passive Cooling System, SM Thesis, MIT Dept. of Nuclear Science and Engineering, Sept. 2007

18. L. Debesse, The Use of Frequency-Consequence Curves in Future Reactor Licensing, SM Thesis, MIT Dept. of Nuclear Science and Engineering, Feb. 2007

19. A. Boogaerts, Cross Comparison of Neutronic Performance of Gen-IV Fast Reactors, Master's Thesis, University Libre de Bruxelles, Sept. 2007

20. S.A. McKee, Implementation of Vented Fuel Assemblies in the Supercritical $\mathbf{C O}_{2}$-Cooled Fast Reactor, SM Thesis, MIT Dept. of Nuclear Science and Engineering, May 2008

\section{Dual Publication}

In general theses are also issued separately as topical reports having substantially the same, if not identical content.

The following key identifies these twin publications: 


\section{Report}

MIT-ANP-TR-086

MIT-ANP-TR-100

MIT-ANP-TR-103

MIT-ANP-TR-104

MIT-GFR-007

MIT-GFR-013

MIT-GFR-024

MIT-ANP-TR-107

MIT-GFR-036

MIT-ANP-TR-112

MIT-ANP-TR-113

MIT-NES-TR-007

MIT-GFR-043

\section{Thesis Version}

SM Thesis by Kun Yu

ScD Thesis by V. Dostal

SM/SB Thesis by K. Gezelius

SM Thesis by M.A. Pope

SM Thesis by J. Plaue

SM Thesis by M.J. Delaney

SM Thesis by C. Matos

ScD Thesis by P. Yarsky

SB Thesis by D.M. Legault

$\mathrm{PhD}$ Thesis by M.A. Pope

PhD Thesis by C.S. Handwerk

SM Thesis by M.J. Memmott

SM Thesis by S.A. McKee 
NERI Distribution List

Final Report

\begin{tabular}{|c|l|}
\hline Internal: & \\
\hline M. J. Driscoll & mickeyd@mit.edu \\
\hline G. Apostolakis & apostola@mit.edu \\
\hline P. Hejzlar & hejzlar@mit.edu \\
\hline E. Shwageraus & eush@bgumail.bgu.ac.il \\
\hline External: & \\
\hline $\begin{array}{c}\text { U.S. DOE, Idaho Operations Office } \\
\text { Procurement Services Division }\end{array}$ & psdrept@id.doe.gov \\
\hline Seb Klein & kleinsm@id.doe.gov \\
\hline Kenny K. Osborne & kenny.osborne@nuclear.energy.gov \\
\hline John Herczeg & john.herczeg@nuclear.energy.gov \\
\hline Robert Versluis & rob.versluis@nuclear.energy.gov \\
\hline $\begin{array}{c}\text { Office of Scientific \& Technical } \\
\text { Information (OSTI) }\end{array}$ & http://www.osti.gov/elink \\
\hline Tom Wei & tycwei@anl.gov \\
\hline
\end{tabular}

